\title{
OUTLINES OF THE GEOLOGY OF BRAZIL TO ACCOMPANY THE GEOLOGIC MAP OF BRAZIL ${ }^{1}$
}

\author{
BY JOHN CASPER BRANNER
}

(Presented by title before the Society December 28, 1917)

\section{CONTENTS}

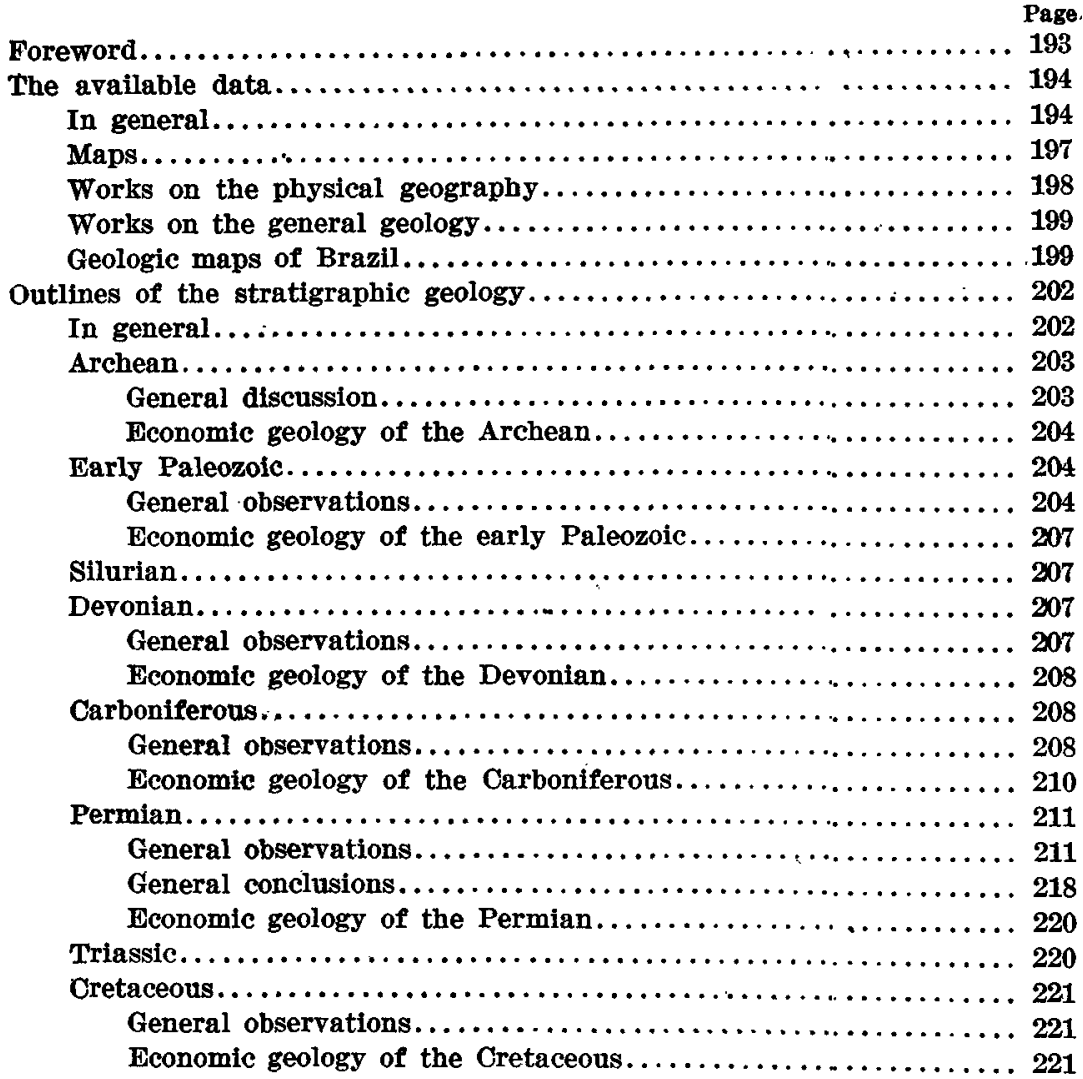

${ }^{1}$ Revised manuscript received by the Secretary of the Soclety May 20, 1918.

This paper was presented to the Soclety under the title "Geologic Map of Brazil." 
Tertiary $\ldots \ldots \ldots \ldots \ldots . \ldots \ldots$

General observations............................. 221

Economic geology of the Tertiary $\ldots \ldots \ldots \ldots \ldots \ldots \ldots \ldots \ldots 222$

Petrography ...................................... 222

Outlines of the general and economic geology and bibliography by states.. 223

General observations.............................. 223

Acre............................................ 224

Previous investigations.......................... 224

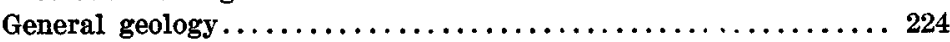

Economic geology.............................. 224

Bibliography of the geology of Acre..................224

Alagoas......................................... 225

Previous investigations.......................... 225

General geology .............................. 225

Economic geology ............................. 227

Geologic map of Alagoas........................ 227

Bibliography of the geology of Alagoas................ 228

Amazonas...................................... 228

Previous investigations.......................... 228

General geology .............................. 229

Economic geology . . . . . . . . . . . . . . . . . . . . . . . . 230

Geologic maps of Amazonas......................... 230

Bibliography of the geology of Amazonas............... 231

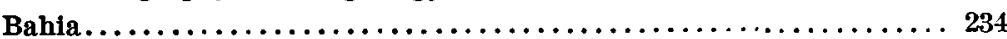

Previous investigations....................... 234

General geology............................... 234

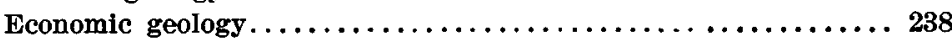

Geologic maps of Bahia......................... 239

Bibliography of the geology of Bahia................. 240

Ceara.......................................... 244

Previous investigations............................244

General geology ............................... 245

Economic geology $\ldots \ldots \ldots \ldots \ldots \ldots \ldots \ldots \ldots \ldots \ldots \ldots \ldots \ldots \ldots \ldots \ldots \ldots$

Geologic maps of Ceará....................... 247

Bibliography of the geology of Ceara............... 248

Espirito Santo................................. 249

Previous investigations.......................... 249

General geology $\ldots \ldots \ldots \ldots \ldots \ldots \ldots \ldots \ldots \ldots \ldots \ldots \ldots \ldots \ldots$

Economic geology ............................. 250

Geologic map of Espirito Santo.................. 250

Bibliography of the geology of Espirito Santc........... 250

Goyaz....................................... 251

Previous investigations.......................... 251

General geology $\ldots \ldots \ldots \ldots \ldots \ldots \ldots \ldots \ldots \ldots \ldots \ldots \ldots \ldots \ldots \ldots \ldots \ldots$

Economic geology ...........................

Bibliography of the geology of Goyaz................ 253

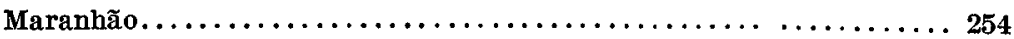

Previous investigations........................ 254

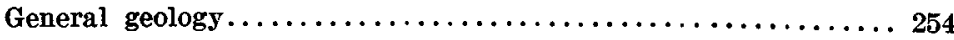


Page

Economic geology ........................... 255

Geologic map of Maranbão...................... 255

Bibliography of the geology of Maranhão............. 255

Matto Grosso .............................. 256

Previous investigations. . . . . . . . . . . . . . . . 256

General geology .......................... 256

Economic geology........................... 261

Geologic maps of Matto Grosso................... 261

Bibliography of the geology of Matto Grosso... . . . . . . . 262

Minas Geraes............................... 263

Previous investigations. . . . . . . . . . . . . . . . 263

General geology .......................... 264

Economic geology ......................... 268

Geologic maps of Minas Geraes................... 271

Bibliography of the geology of Minas Geraes............. 271

Park..................................... 281

Previous investigations $\ldots \ldots \ldots \ldots \ldots \ldots \ldots \ldots \ldots \ldots \ldots \ldots \ldots$

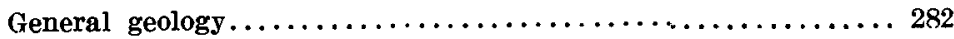

Economic geology .......................... 282

Geologic maps of Para........................ 282

Bibliography of the geology of Para. . . . . . . . . . . . 283

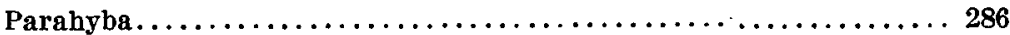

Previous investigations. . . . . . . . . . . . . . . . . . 286

General geology ........................... 286

Economic geology . . . . . . . . . . . . . . . . . . . . 286

Geologie maps of Parahyba.................... 287

Bibliography of the geology of Parahyba.............. 287

Parank.................................. 288

Previous investigations....................... 288

General geology ............................ 288

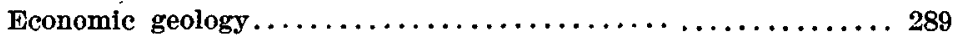

Geologic maps of Parank. . . . . . . . . . . . . . . . . . . 289

Bibliography of the geology of Parana... . . . . . . . . . . . 290

Pernambuco.................................. 291

Previous investigations. . . . . . . . . . . . . . . . . . . 291

General geologs . . . . . . . . . . . . . . . . . . . . . . 292

Economic geology ............................. 293

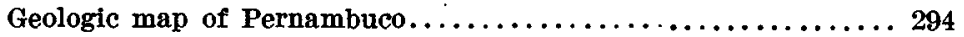

Bibliography of the geology of Pernambuco... . . . . . . . . 294

Piauhy .................................... 297

Previous investigations....................... 297

General geology ............................. 297

Economic geology ............................ 298

Geologic maps of Piauhy ....................... 298

Bibliography of the geology of Piauhy . . . . . . . . . . . 299

Rio de Janeiro, the Federal District, and Trindude. . . . . . . . . . 299

Previous investigations. . . . . . . . . . . . . . . . . . . 299

General geology .......................... 300

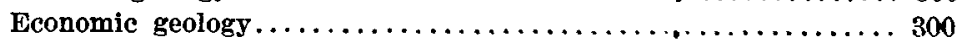


Page
$\mathbf{3 0 1}$

Geologic maps of Rio de Janeiro ................... 301

Bibliography of the geology of Rio de Janeiro.... . . . . . . 301

Rio Grande do Norte. . . . . . . . . . . . . . . . . . . . . 304

Previous investigations. ...................... 304

General geology ........................... 304

Economic geology .......................... 305

Geologic maps of Rio Grande do Norte............... 305

Bibliography of the geology of Rio Grande do Norte . . . . . . 305

Rio Grande do Sul. . . . . . . . . . . . . . . . . . . . . . 306

Previous investigations. ...................... 306

General geology ............................ 307

Economic geology ........................... 308

Geologic maps of Rio Grande do Sul. . . . . . . . . . . . . 308

Bibliography of the geology of Rio Grande do Sul........... 309

Santa Catharina............................ 313

Previous investigations...................... 313

General geology . ........................... 314

Economic geology $\ldots \ldots \ldots \ldots \ldots \ldots \ldots \ldots \ldots \ldots \ldots \ldots \ldots \ldots \ldots$

Geologic map of Santa Catharina ................. 314

Bibliography of the geology of Santa Catharina . . . . . . . . 314

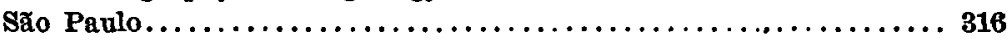

Previous investigations. . . . . . . . . . . . . . . $\ldots \ldots$

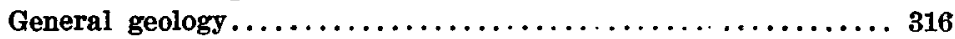

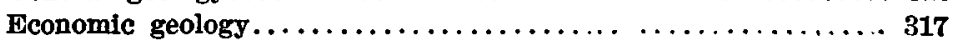

Geologic maps of săo Paulo..................... 318

Bibliography of the geology of São Paulo............. 318

Sergipe.................................... 321

Previous investigations. ...................... 321

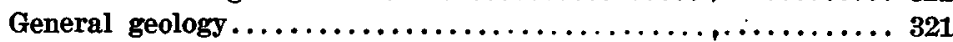

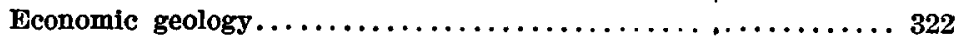

Geologic maps of Sergipe...................... 322

Bibllography of the geology of Sergipe. $\ldots \ldots \ldots \ldots \ldots \ldots \ldots \ldots, \ldots \ldots$

Outlines of the economic geology $\ldots \ldots \ldots \ldots \ldots \ldots \ldots \ldots \ldots \ldots$

General observations.......................... 323

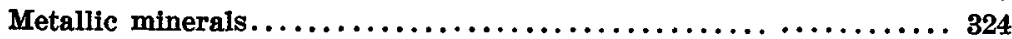

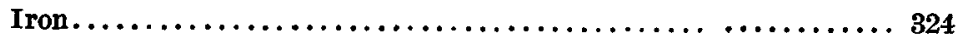

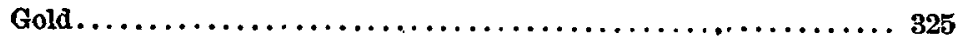

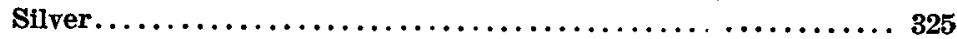

Copper.................................. 325

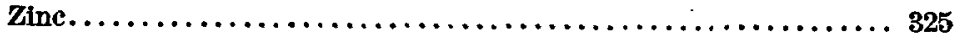

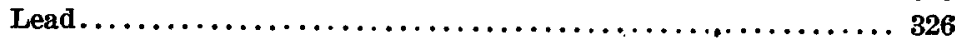

Tin.................................. 326

Manganese.............................. 326

Nickel. . . . . . . . . . . . . . . . . . . . . . . . . . . 327

Chromium.............................. 327

Platinum...............................

Palladium $\ldots \ldots \ldots \ldots \ldots \ldots \ldots \ldots \ldots \ldots \ldots \ldots \ldots \ldots \ldots \ldots \ldots \ldots$

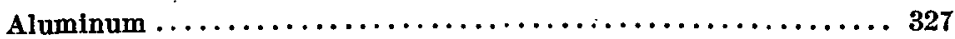

Tungsten................................. 327 
Page
Page

Mercury...............................

Molybdenum............................. 327

Non-metallic minerals $\ldots \ldots \ldots \ldots \ldots \ldots \ldots \ldots \ldots \ldots \ldots \ldots \ldots \ldots \ldots$

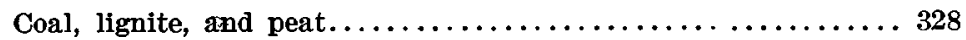

Petroleum and oil shales. .................... 328

Asphalt. ................................ 329

Building stones $\ldots \ldots \ldots \ldots \ldots \ldots \ldots \ldots \ldots \ldots \ldots \ldots \ldots \ldots \ldots$

Marble.................................. 329

Limestone. . . . . . . . . . . . . . . . . . . . . . 329

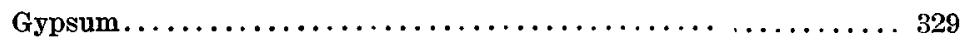

Anhydrite. ................................ 329

Magnesite................................. 329

Kaolin, clay, fullers earth. . . . . . . . . . . . . . . . . 329

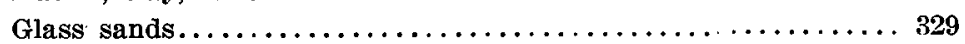

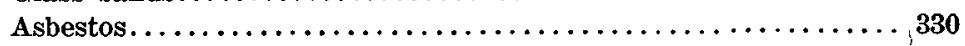

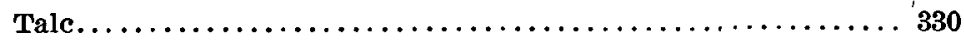

Mica................................. 330

Salt................................. 330

Niter. ............................... 330

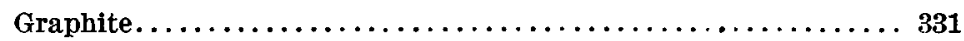

Bauxite............................... 331

Monazite................................ 331

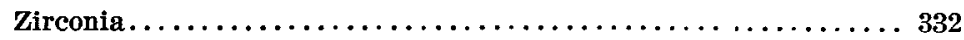

Phosphates.............................. 332

Diamonds................................ 332

Carbonados, or black diamonds................. 333

Other precious stones....................... 334

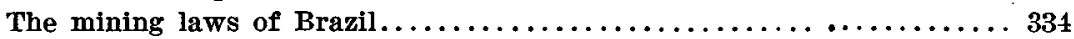

General observations......................... 334

Bibliographic references to mining laws $\ldots \ldots \ldots \ldots \ldots \ldots \ldots \ldots$

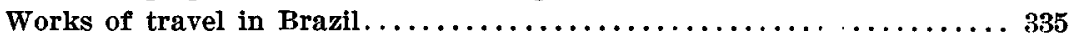

Climatic conditions.............................. 337

\section{FOREWORD}

The accumulation of the data for a geologic map of Brazil was begun by me in $18 \% 4$, when I first went to that country, and has been kept up, as opportunities offered, down to the present time. The gathering and study of the material and the preparation of the map may therefore be said to represent the work of a considerable portion of a lifetime.

The data brought together on the map and in the accompanying text are published by the Geological Society of America primarily as a contribution to the world's knowledge of the geology of America; but, so far as I am concerned, it is meant especially to be of service to the Brazilian people, among whom I have spent many years, to whom I am strongly attached, and in whose welfare I am deeply interested. 
It has been one of the greatest pleasures of my life that I have been able thus to contribute something to the knowledge of the geology of the country in which I began my professional career.

After a life spent chiefly in active geologic work and in the direction of such work, I should be remiss in my duty to Brazil if I did not use this occasion to urge on Brazilian statesmen the serious necessity for the active encouragement and support of scientific geologic work on the part of the national and state governments. Knowledge must precede the application of knowledge in geology as well as in other matters; and unless the development of the country's mineral resources be based on and proceed from a scientific knowledge of its geology, there must inevitably be waste of effort, loss of money, and the delay of national progress inseparable from haphazard methods.

\section{The available Data}

IN GENERAL

Our knowledge of the geology of Brazil has hitherto been so fragmentary and uncertain that the generalized geologic maps thus far published have failed to furnish any clear conception of the geology of that country as a whole.

Many of the uncertainties, however, are not due to the lack of data, but rather to a lack of acquaintance with and coordination of data. By bringing together everything known and published on the geology of Brazil, and by seeking a rational interpretation of the available facts, it has been found possible to represent the general geology of the country fairly well. There are necessarily many and large areas about which little or nothing is known, and there are many questions about the ages and correlations of the rocks, their precise distribution, their structural details, and their mineral resources, that must go unanswered for the present or be answered only tentatively; but such doubts and uncertainties are inseparable from all progress in scientific work.

One who knows little or nothing of the difficulties of gathering geologic information in the field in Brazil may be disposed to place too low an estimate on the amount and character of the information shown on the map. But it should be kept in mind that the country is enormously big and, on the whole, but thinly populated; that vast areas therein are not yet penetrated by railways; that there are as yet but few good wagon roads in the country; and that the difficulties of travel and transportation in parts of the country remote from railways and navigation are not only serious, but sometimes almost insuperable. 
Enormous areas of the country are also covered by dense and almost impenetrable forests, and of these trackless regions, some of them larger than the State of Pennsylvania, there are no maps whatever.

Of a necessity the gathering of geologic information under such circumstances is much more difficult than it is in a country like North America, where we have roads everywhere, railways never far away, and most of our forests open to persons on foot or even on horseback, to say nothing of the helpfulness of our excellent Land Office maps, even when there is nothing better available.

Furthermore, only two of the States, São Paulo and Minas Geraes, have attempted geological surveys, and there has been a federal survey only since $190 \%$. With these important exceptions, there is, therefore, no bureau of the government to which geologists, engineers, or the public can turn for information about the geology of the country.

These facts, and others that need not be mentioned, have led me to value highly every bit of geologic information that has come to my knowledge, no matter how small it may be; indeed, much of the data has been gathered from individuals and from all kinds of publications, scattered far and wide, and many of them difficult or even impossible of access to most people.

But, as all human knowledge is imperfect and must, of a necessity, remain so, the best we can do is to push forward little by little the frcitiers of our information, and, holding on firmly to such knowledge as we have, add to it as opportunity offers. It is only so that science makes progress in any country and in any field. In such spirit this map has been prepared, for the purpose of showing the state of our knowledge of the geology of Brazil and to prepare the way for additions to that knowledge.

The scale of the map makes it quite impossible to show many of the details that are known of the geology of some regions, while so little is known of other regions that the only safe thing to do is to leave the areas blank until our knowledge shall have been extended.

The geology shown on the map is based largely on personal observations covering a period of ten years of actual work and travel in all of the Brazilian States except Goyaz and Piauhy. Much aid has been received also from the unpublished notes of Roderic Crandall, who was some time my assistant and who did valuable work on the geology of Bahia, Minas, Ceará, Alagoas, Sergipe, and Amazonas. This direct information has been supplemented by all the data published and by much that is unpublished, but kindly furnished by friends and acquaintances who have a personal knowledge of the geology of certain parts of Brazil. 
This statement is necessary because the map may otherwise seem to be more detailed than the published data seem to warrant.

Next after my personal observations and those of my assistants I have sought the original sources of all trustworthy information about the geology of Brazil-information scattered through books of travel and even through the daily newspapers of that country, as well as through the scientific publications of all parts of the world.

The observations of some of the early geologists have been made diffcult by their use of certain terms. The word "itacolumite," for example, has been especially confusing, while the words "uebergangschiefer," traumatic shales, "formation phylladienne," and such like expressions keep one in constant doubt about the precise meaning of the authors using them.

The text accompanying the geologic map of Brazil is not intended to explain or give details regarding the geology, but simply to provide a brief condensation of what is known and to enable those who use the map, or who seek information about the geology of Brazil, to start with a fairly clear idea of what is known, and to obtain at first hand all of the published information that exists in regard to the geology of the country and of each state.

In view of the limitations of our knowledge, it is not possible to represent on the map more than thirteen subdivisions of the geologic column. In some localities many more subdivisions are known and over a limited area might have been shown, but there would be no particular object in giving all of these subdivisions on a map of this scale. The minor details, even where they are known, are necessarily omitted on account of the small scale of the map. In regions of horizontal rocks where partings are dendritic in form and outliers are abundant, these features can not conveniently be shown. The areas of old crystalline schists are almost everywhere traversed by dikes of eruptive rocks, but these dikes are usually too small to be shown on a map of the scale of this one. The same thing is true in the southern states, where numerous dikes cut all of the rocks below the Cretaceous.

Inasmuch as interest in the geology of Brazil is likely to be more or less a special interest in some particular branch, it seems worth while to refer to the available sources of information in regard to the different branches of geology, such as economic geology, paleontology, petrography, etcetera, and to other matter that geologists may need to know.

Many of the books and papers cited are not only not on geology, but they contain very little geological information; but the stray notes of a 
traveler in little known regions often afford valuable clues, and sometimes they are the only ones we have.

\section{$M A P S$}

The maps of Brazil, like those of other countries, are not all good. There is no trustworthy large scale general map of the country. Some of the states have no surveys and are poorly provided with maps; others have lately undertaken good topographic maps, notably São Paulo and Minas Geraes. The São Paulo topographic maps are on a scale of 1 to 100,000 , with 25 meters contour intervals, and five sheets have now been published. The topographic maps of Minas Geraes are on a scale of 1 to 100,000 , with 50 meters contour intervals; ten sheets have been published. Of late years the need of trustworthy maps compelled the Inspectoria de Obras Contra as Seccas to make their own maps of several of the northern states in which drouths occur, notably in Piauhy, Ceará, Rio Grande do Norte, Parahyba, Pernambuco, Sergipe, and Bahia, and though made mostly by horseback meanders, are noteworthy as being the most valuable additions made of late years to the cartography of those states. This work was planned and carried out by the distinguished Brazilian geologist and engineer, Dr. Miguel Arrojado R. Lisboa, while he was director of the Inspectoria de Obras Contra as Seccas, and these maps have been our chief source of information in regard to the geographic details of the states so mapped.

In 1913 the Inspectoria Federal das Estradas, under the inspectorship of Dr. José Estacio de Lima Brandão, published a valuable modern atlas of the railways of Brazil; but the sheets are on various scales and are hardly available for the purposes of geologists. The atlas of Homen de Mello gives as good maps of the states as can be had on a small scale. The first edition of his work was published in 1882; the last in 1909 . There are maps of most of the states, some of them remarkably good in view of the lack of trustworthy data for their construction.

The base map used for the geology has been compiled especially for the purpose by using all available data, in so far as it can be shown on a map of this scale. Dr. L. A. Bauer, Director of the Department of Terrestrial Magnetism of the Carnegie Institution, has kindly furnished me all the available determinations of latitude and longitude made under his direction in Brazil. I have also had the determinations made under Dr. H. Morize, director of the astronomical observatory at Rio de Janeiro, besides the results of the magnetic survey of eastern Brazil by Dr. Van Ryckevorsel and E. Encelenburg, published at Amsterdam in 1890.

Unfortunately it is impossible at present to tie into this network many 
other places that should be or are shown on the map, and the location of geological data thus becomes very unsatisfactory in many instances. Notes under most of the states mention the authorities for the map of the state. Boundaries between the states are not yet definitely settled, and no importance can be attached to state boundaries given on the map. Only railways actually constructed are shown on the map. Flamsteed's projection is used as being the one best adapted to an equatorial region.

\section{WORKS ON THE PHYSIOAL GEOGRAPHY}

Below are mentioned the principal works on the physical geography of Brazil :

Eschwege's sketch of the geology of Brazil, published in the Annales des Mines, volume VIII, 1823, is given in Portuguese at pages 35-39 of the appendices to Boubée's Geologia Elementar, Rio de Janeiro, 1846.

On the physical features of the country there is nothing better than the work of Elysée Reclus. His volume on Brazil has been translated into Portuguese by Dr. Ramiz Galvão, and many valuable corrections and notes have been added by the translator.

An older and less comprehensive work is Hartt's book on the Physical Geography and Geology of Brazil. It is primarily devoted to geology, but it brought together most of the data on the physical features of Brazil published up to $18 \%$, when it appeared, and added Hartt's own observations along the coast from Rio de Janeiro to Bahia.

A much shorter paper by Derby is given in Wappaeus" "Geographia physica do Brazil," chapter V, pages 44-59, with a map. It appeared also in the Portuguese translation of Lapparent's Géologie, pages 333-343. This is in the Portuguese language. The same article was republished in English in The Rio News of December 5 and 15, Rio de Janeiro, 1884, and in the Annuaire géologique universel II, $2^{\mathrm{e}}$ parte, pages 29-35, Paris, 1886. The Revista Italo-Americana, volume I, Roma, 1902, contains a paper by Vincenzo Grossi entitled "Appunti sulla geografia fisica del Brasile." In The Brazilian Year Book for 1909, published at Rio de Janeiro, Mr. Derby's article on the physical and geological features of Brazil are given at pages 11 to 14 .

A late interesting work that contains much valuable information is that of Dr. C. M. Dekgado de Carvalho, entitled "Geographia do Brasil," $8^{\circ}, 253$ pages, Rio de Janeiro, 1913. There is a short but comprehensive article by the same author in the Scottish Geographical Magazine, February, 1918, volume XXXIV, pages 41-55.

Dr. M. A. R. Lisboa is preparing a comprehensive work on the physical 
features of Brazil that will bring the subject up to date. I am unable to give the title of the work, however.

\section{WORKS ON THE GENERAL GEOLOGY}

There are but few books on the general geology of Brazil. Hartt's Geology and Physical Geography of Brazil, published at Boston in 18\%0, was the first considerable work treating of the geology of Brazil as a whole. The book is now long out of print, but copies are occasionally offered by dealers, and it can be found in most of our large libraries.

The article by H. Gorceix, in "Le Grande Encyclopédie," chapter IV of the second edition, Paris, 1889 , is a short but good one on the general geology of Brazil.

In 1906 Branner's Geologia Elementar was published in Portuguese at Rio. This work was meant for a text-book for the use of Brazilian students, but the third part contained a résumé of the geology of Brazil. The second edition of this book was published in 1915, and the third part, on historical geology, gives brief statements of the distribution of rocks of different ages wherever they are known, and the footnotes refer to the authorities.

Rodolpho von Thering, in his little book entitled "Landeskunde der Republik Brasilien," Leipzig, 1908, gives at pages 17-27 a sketch of the broad features of the geology of Brazil. It is a brief but good compilation from some of the best sources.

\section{GEOLOGIC MAPS OF BRAZIL}

Several attempts have been made to produce geologic maps of Brazil, but in most cases the maps have been on very small scales, and the geology has been represented by broad generalizations and necessarily based on very limited knowledge.

One of the difficulties any one encounters who undertakes such a map is the impossibility of correlating the geology of one area with that of another. This is difficult or quite impossible, even for those who do the field-work itself; but when one tries, from data gathered by two or more different geologists, to reconcile their differences of interpretation, and to correlate when the data for correlation are not available, it is clearly impossible to obtain results satisfactory to one's self or to others, especially if nice discriminations are attempted.

A. D'Orbigny, 1842.-The first geologic map of Brazil seems to have been one forming part of the "Carte de l'Amérique Méridionale indiquant ses differentes époques géologiques, par A. D'Orbigny," dated 1842 and published as plate $\mathrm{X}$ of "Voyage dans l'Amérique Méridionale, . . . par 
M. Alcide D. D'Orbigny," tome III, $3^{\mathrm{e}}$ partie, Géologie, Paris, 1842. The map shows all of South America on a scale of 1 to 18,333,333. The gcology is not shown in the usual way, but shaded areas represent the continent without geographic details subsequent to four geologic periods, namely, "apres les terrains siluriens," "apres les terrains carbonifères," "apres les terrains triassiques," and "apres les terrains crétaces." This chart, however, is a geologic diagram rather than a geologic map of South America.

Francisco Foetterle, 1854.-The next geologic map of Brazil of which I have any knowledge is that of Francisco Foetterle. It is entitled "Golpe de vista Geologico do Brazil, e de algumas outras partes centraes da America do Sul promptificado no Instituto Geologico Imperial Real Austriaco fundado e dirigido pelo Professor Guilherme Haidinger por Francisco Foetterle em Vienna em Avril 1854."

This map was made for Dr. K. Fr. Ph. von Martius, the Brazilian explorer, by Dr. Franz Foetterle, who was at the time an assistant on the K. K. geologischen Reichsanstalt. I had the good fortune to see the original of this map at the rooms of the Geological Society of London in 1904. The author had made himself familiar with most of the data published up to that time on the geology of Brazil and of the adjacent regions. Altogether it is a remarkable map, evidently made by a discriminating and painstaking person. In the title itself are given the names of the authorities consulted, and, besides the geology, there are many marginal notes on elevations and historic data of interest. The geology is shown entirely across the South American continent, from 5 degrees north latitude to 35 degrees south latitude.

The scale is 1 to $15,000,000$ and the geologic coloring shows the following divisions: five divisions for granites, gneiss, itacolumite, and schists (chloritic and traumatic) ; Silurian, Devonian, amphibolite, limestone, Carboniferous, Trias, marl, red sandstone, volcanics, Tertiary, diluvium (pampas), and special signs for gold, diamonds, iron, and coal.

In the light of our present knowledge of the geology of Brazil, Foetterle's map must be regarded as having but little more than a historical value.

Franz Foetterle, 1856.--In Petermann's Mittheilungen, Gotha, 1856, Franz Foetterle has an article at pages 187-192, on "Die Geologie von Süd-Amerika," which is accompanied by a geological map of the entire continent of South America on a scale of 1 to $25,000,000$. In so far as Brazil is concerned, it is a repetition of his map of 1854. On this smaller one he shows fourteen geologic divisions. 
J. E. Wappaeus, 1884.- “A geographia physica do Brasil” (Edição condensada), Rio de Janeiro, 1884. This work contains a chapter by Orville A. Derby on the structural geology and minerals of Brazil. The text forms chapter $\mathrm{V}$, pages $\mathbf{4 4}$ to $\mathbf{5 9}$, and it is accompanied by a sketchmap made by Derby showing the geology of Brazil. The scale is very small (about 1 to 90 millions) and the geological column is shown in six divisions, namely: Archean, Paleozoic, Carboniferous, Trias (?), Cretaceous, and Tertiary and Quaternary (combined). No attempt is made, however, to show these subdivisions over more than about half of the area of Brazil. The text accompanying this map is based partly on Derby's personal knowledge, but no references are made to the other sources of information used in the preparation of the map.

Dr. Hermann Berghaus, 1892.- “Atlas der Geologie" (Berghaus' Physikalischer Atlas, Abteilung I), Gotha, Justus Perthes, 1892. Plate number 14 shows the geology of the whole of South America; it seems to have been compiled chiefly by Dr. G. Steinmann. It is on a scale of 1 to 30 millions. There are eleven subdivisions of the geologic column, as follows: (1) Archean, (2) younger eruptives, (3) crystalline schists, (4) Paleozoic, (5) coal beds with Glossopteris flora, (6) Jura and Trias (not in Brazil), (7) Mesozoic, (8) Cretaceous (?), (9) basic eruptives, (10) Tertiary, (11) Quaternary.

Domicio da Gama, no date.-In his "Atlas universal de geographia physica e politica, nova edição correcta, por Domicio da Gama, Rio de Janeiro," no date, the author gives on plate 32 a geologic map of Brazil. This map has not been seen by the present writer.

Barão Homem de Mello e Dr. Francisco Homem de Mello, 1909."Atlas do Brazil," Rio de Janeiro, 1909. A plate entitled "Esboço da carta geologica do Brazil," on a scale of 1 to 19 millions, represents the general geology of Brazil. There are only four colors used for the geology, as follows: Archean and Lower Paleozoic, Middle and Upper Paleozoic, Mesozoic, and a single color for both Tertiary and Quaternary. No author's name is given on the plate, nor does the text make any mention of the name of the person responsible for the geology shown, but Barão Homem de Mello informs me that it was prepared for him by 0 . A. Derby. The fact that no authority is mentioned on the map is probably because Mr. Derby was very cautious about committing himself to the generalizations required for a map of the kind; and no one knew better than he did the limitations of our knowledge of the geology of Brazil.

Manoel Paulino Cavalcanti, 1910.-A series of maps of Brazil showing climate, agriculture, statistics, and geology was published at Rio de Janeiro in 1910 by the Sociedade Nacional de Agricultura under the 
editorship of Dr. Manoel Paulino Cavalcanti, director of the Posto Zootechnico Federal. It is on a scale of 1 to 12 millions. Eight subdivisions of the geologic column are shown, namely: Quaternary, Tertiary, Cretaceous, Trias, Carboniferous, Devonian, Silurian, and Archean. Though this map is largely diagrammatic, it is the most dependable effort thus far made to produce a geologic map of Brazil.

Theodoro Sampaio, 1911.-In his "Atlas dos Estados Unidos do Brazil pelo Engenheiro Civil Theodoro Sampaio," published at Bahia in 1911, the author of that work gives a small geological map of Brazil on a scale of 1 to 40 millions. Six geologic divisions are shown. In spite of the very small scale, it is among the best geologic maps of that country.

Miscellaneous reproductions.-Several small maps have been published showing the general geology of Brazil, but they have evidently been made from some of the larger maps already mentioned. One that may be taken as an example is that given by Prof. James Geikie in his paper, "The evolution of climate," published in The Scottish Geographical Magazine, volume VI, pages 57-7\%, Edinburgh, 1890, and accompanied by small scale maps of the geology of the globe. The title of the map, however, says that it is "after Berghaus, Marcou, and other authorities."

Another geological map of South America on a scale of 1 to 50 millions is given opposite page $5 \%$, in "Süd und Mittelamerika von Wilhelm Sievers, Leipzig und Wien, 1903." The title of this map says it is after Berghaus and others.

In addition to these maps of the whole country, a few geologic maps of some of the states or provinces have been published; these state maps will be mentioned in the bibliographic reference to the states themselves.

\section{OUtlines of the stratigraphic Geologx}

\section{IN GENERAL}

The text on the stratigraphy is intended to give only a brief outline of the general geology of Brazil, including statements of the character of the rocks, structural features, areal distribution, and the subdivisions of the geologic column - enough, it is hoped, to guide geologists, and to serve as a basis for future work.

If more details are required they may be found (in case they are known and published) in Branner's Geologia Elementar, second edition, or in the papers cited in the bibliographies of the different states.

In the course of the preparation of the map many problems regarding stratigraphy have demanded attention, and they had to be dealt with in order that the work might go forward. 
It has not been my purpose, however, to settle controverted questions in Brazilian geology further than the facts warrant or further than was necessary in order to put the geology on the map in one way or another. I have frankly stated doubts wherever they exist, and I ask the indulgence of those who may reach different conclusions in regard to the many disputed problems. It is hoped that even the statement of doubts and differences of opinion may help toward their settlement by leading to the accumulation of evidence in the field. The field geologist must therefore feel at liberty to look on the solutions here suggested as working hypotheses, to be confirmed if found correct, or to be rejected if found wrong.

In regard to the areas left blank on the map, there is no information available at present.

\section{$\triangle R C H E A N$}

General discussion.-The rocks referred to the Archean in Brazil are granites, gneisses, quartzites, marbles, and crystalline schists. Too little is known of these old rocks at present to warrant such a separation of them as has been made of similar rocks in North America ; for that reason they are called the Brazilian complex. Many years ago it was believed that Eozoon canadense, a supposed fossil foraminifer supposed to be characteristic of the Laurentian, had been found in the Brazilian Archean near the falls of Paulo Affonso, in the State of Alagoas. Derby said of it: "Esta descoberta confirma a opinião emittida pelo fallecido Professor Hartt sobre a idade geologica dos gneiss brazileiro." " The supposed fossil, however, is not now regarded as a fossil at all, and no further attempt to subdivide the Archean of Brazil has been made or can be made as yet. Rocks of the Brazilian complex are found in all of the states, and the area in which they are the surface rocks in Brazil is large, and much of it not yet outlined, while the structure and character of the rocks vary greatly. About Rio de Janeiro and through the Serra do Mar generally they are mostly massive granites and gneisses. In northern Brazil they are more closely folded; everywhere they are faulted and cut by pegmatite and other dike rocks and traversed by reins of quartz.

But little is known of the structure of the Brazilian complex. Much information on the subject is scattered through the literature, but widely separated areas can not be confidently tied together with the data now available. Even the "chief lines of elevation or folding" suggested by

\footnotetext{
20. A. Derby : Reconhecimento geologico do Valle do Săo Francisco, p. 11 . Rio de
} Janeiro, 1881. 
Dr. John W. Evans ${ }^{3}$ are not supported, so far as Brazil is concerned, by our knowledge of the local details.

Over much of the Archean area are scattered infaulted remnants of old Paleozoic rocks that yield a peculiar and characteristic topography. The infaulted masses are of all sizes, from areas of thousands of square kilometers down to only a few square meters. These rocks, however, belong with the next newer series, where they are spoken of more at length.

Economic geology of the Archean.-Our imperfect knowledge of the stratigraphic limits of the Archean rocks of Brazil makes it difficult to know precisely what rocks and minerals are to be credited to that division of the geologic column. Furthermore, minerals that probably originated in newer rocks are now often found in the Archean areas, where they have been left by the denudation of later series to which they properly belong. On the other hand, the Archean rocks are the original sources of certain minerals that are now found in later deposits in which they have been concentrated, as, for example, the monazite sands of the coasts. It can confidently be stated that the Archean rocks of Brazil contain many minerals which have not yet been developed economically in that country. The entire list includes gold, copper, platinum, tungsten, mica, marble, talc, apatite, graphite, potash-bearing rocks, precious stones, and excellent building stones. This list, however, is not complete.

\section{EARLT PALEOZOIO}

General observations.-The separation of the rocks of the Brazilian complex from the next newer series can not be made with confidence at present, but for purposes of discussion the top of the Archean is placed at the base of the quartzite called "itacolumite," in Minas.

The groups of rocks here called early Paleozoic can not be clearly defined for lack of stratigraphic data. No fossils have been found in any of them. Many of them have been profoundly metamorphosed; others have been much less affected; over vast areas they have been almost completely removed by denuding agencies, but over these same areas remnants of the old Paleozoic sediments stand out in bold relief as isolated knobs, peaks, and even as bold and rugged mountain ranges. The rocks vary from soft clay shales to the hardest of quartzites, the quartzites invariably forming the ridges, while in the parallel shale beds intervening valleys have been cut. Within limited areas the structural features are sometimes remarkably uniform, though not perfectly so. The structure shows that these early Paleozoic sediments have been extensively dislocated by thrust-faults and one end of the beds thrust down into the underlying

auart. Jour. Geol. Soc., vol. Ixil, p. 90. London, 1906. 
gneisses and granites. The result is a section somewhat like the ones here shown, but varying according to the angle of the fault-plane, the amount of the thrust, etcetera. These early Paleozoic beds are thus brought into intimate relations with the Archean rocks, and it seems quite probable that the high metamorphism and the presence of so many characteristic and valuable minerals may be due, in part at least, to these relations. The dips of the beds are generally high, and not infrequently the beds are nearly or quite vertical. The statement is sometimes made that the dip is always toward the east, ${ }^{4}$ with a rugged outcrop on the west;

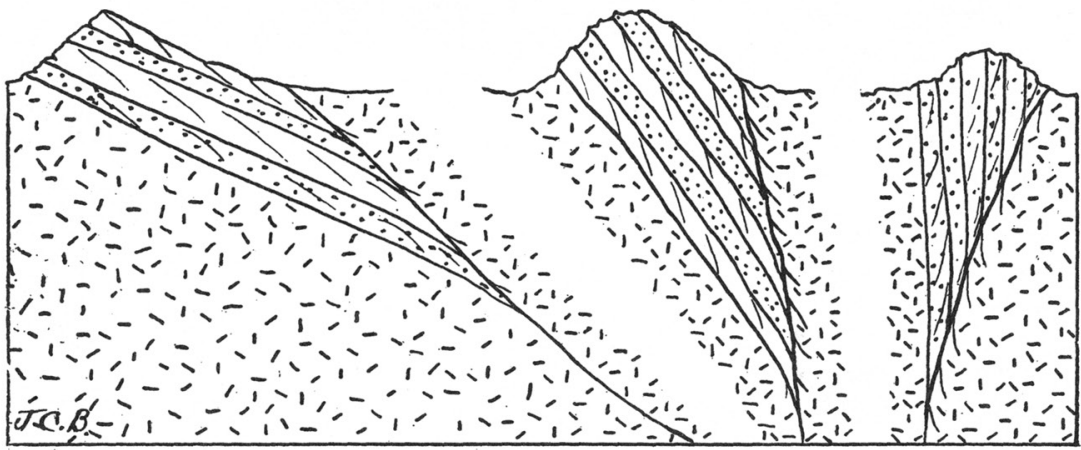

FIGURE 1.-Theoretic Structure of Thrust-faulting of early Paleozoic into the Archean

this is locally, and only locally, true. In the State of Bahia the Serra de Jacobina, which belongs to this series, dips about 60 degrees toward the east (with slight variations) along its entire length-a distance of 225 kilometers.

In the State of Minas Geraes, where the early Paleozoic beds have been most studied and written about, the direction and angle of the dip varies much, and the sequence of the beds is variously stated by different writers.

I have here brought together the sequence in Minas Geraes as given by eight different geologists :

EschWEge, 1831

Claussen, 1841

(Gebirgskunde Brasiliens)

(Acad. Roy. Bruxelles, volume VIII)

Uebergangsthonschiefer

Terrain transition

Eisenglimmer

Itacolumite-quartz

Urthonschiefer

Traumateux

Itacolumite

Kornquartz

Micacique

Quartzitique

Granite-gneiss

Granite-gneiss

4Heusser u. Claraz: Zeit. Deut. Geol. Gesell., vol. xi, p. 451. Berlin, 1889. XV-Bull. Geol. Soc. AM., Vol. 30, 1918 
HeLmREICHeN, 1846

(Geog. Vorkommen der Diamanten, 1846)

Itacolumite

Talcose and clay slate

Slaty gneiss

Granite-gneiss

GORCEIX, 1881

(Ann. Escola de Minas, volume I)

Paleozoic limestone

\section{Schists}

Iron (itabirites)

Quartzites (Caraça)

Schistose quartzite

Granite-gneiss
Graywacke

Gerber, 1863

(Noções . . . da Provincia de Minas Geraes, 1863, pages $17-20$ )

Transition

Itacolumite

Iron, talc, and steatite

Itabirite

Quartzite

\section{Granite-gneiss}

Francisco de P. Oliveira, 1881

(Ann. Escola de Minas, volume I, page 53)

Limestones, shales, and red sandstones
Itabirites
Talcites and phyllites
Quartzites
Talcose rocks

Talcites-mica schists

Granite-gneiss

Hardeb and Chambertin, 1911

Gonzaga de Campos, 1910

(Iron Ore Resources of the World, Journal of Geology, volume XXIII, volume II, page 816 ) pages 345-347)

Limestones, age?

Iron ore (itabirites)

Itacolumite quartzite

Piracicaba formation

Iron (mostly itabirite)

Sedimentaries

Batatal schists

Caraça quartzite

Granite, gneiss, schists

Crystalline schists and granite

These tables lead to the conclusion that either the various writers on the early Paleozoic rocks of Brazil are not speaking of the same places or else they disagree about the subdivisions of the series. My own observations, both on the rocks themselves and on the writings of these geologists, lead me to believe that the rocks of this series vary from place to

s Helmreichen's section is at Grăo Mogol and it probably does not belong here. 
place just as other sedimentary series do, and that the disagreements of geologists are due to their efforts to generalize from their observations. The scientific and economic importance of this series of rocks in Brazil entitles it to the careful attention of geologists.

Economic geology of the early Paleozoic.-Economically, the early Paleozoic rocks of Brazil are of the greatest importance, for they include not only the gold veins from which existing rock mines obtain their gold, but they are the indirect sources of the gold obtained from the old placer washings. This series also includes the great iron and manganese deposits of Brazil. The diamonds and other precious stones of Brazil are also supposed by some geologists to have originated in these early Paleozoic beds, though there is difference of opinion on this subject. Without going into details, it is evident that this series of rocks is of the greatest economic importance and of the highest scientific interest.

\section{SILURIAN}

The oldest known fossils found in Brazil are from the Silurian, in the States of Amazonas and Pará. (See Clarke and Katzer under those states.)

The Silurian rocks, where they are recognized as such, are marine sediments, mostly in the form of thin-bedded sandstones. They are exposed where crossed by the Trombetas, Curuá, and Maecuru rivers on the north side of the Amazon River, and dip gently southward. On the Trombetas the zone is from six to eight kilometers wide. The fossils show them to be equivalent to the Niagara beds of New York State. Although the rocks that overlie the Silurian north of the Amazon appear again on the south side of that stream, no rocks known, from paleontologic evidence, to be Silurian appear immediately south of the Amazon. ${ }^{6}$

It is highly probable that there are rocks of Silurian age in many other places in Brazil, notably in Bahia and Minas, ${ }^{7}$ but the absence of fossils has thus far prevented their confident identification. ${ }^{8}$

\section{DEVONIAN}

General observations.-The Devonian is found in the States of Amazonas and Pará in the north, in São Paulo and Paraná in the south, and in Matto Grosso in the west. For the fossils found in the Brazilian De-

\footnotetext{
' F. Katzer: Geologie von unteren Amazonas Gebietes, p. 216.

'See Branner: Am. Jour. Sci., vol. xxx, November, 1910, p. 348, and vol. xxxf, June, 1911, p. 481 .

${ }^{8}$ On the Rio Săo Franclsco, at Bom Jesus da Lapa, State of Bahia, are limestones in which fossil corals (Favosites and Chetetes) are said to be found. Derby belleved them to be Silurian, but both forms may well be Carboniferous.
} 
vonian, see the titles under those States by Clarke, Katzer, Kayser, Oliveira (Euzebio de Paulo), Rathbun, Schuchert, Smith, Vogel, and Von Ammon.

In the Amazon region the Devonian rocks are white and yellowish sandstones and black and reddish shales. Along the north side of the Amazon they are exposed.from just north of Almeirim westward to Rio Uatumá, a stream between the Trombetas and the Negro. They dip toward the Amazon at a low angle-about five degrees. At Ereré and elsewhere they are cut by dikes of diabase. South of the Amazon the Devonian rocks are believed to be exposed on Rio Mauéassú south of Laranjal, and on the Tapajos south of Itaituba; but no fossils have yet been found in these particular areas, and there is, therefore, doubt about their precise age. ${ }^{\ominus}$

In Paraná and southern São Paulo the Devonian rocks seem to rest directly on the Brazilian complex and dip gently, westward beneath the Permian. The rocks are conglomerates, sandstones, and shales. The diamonds found in Parana are supposed to come from the basal conglomerate. In Matto Grosso the Devonian rocks are sandstones and shales resting unconformably on rocks of the Brazilian complex and dipping gently eastward. In Bahia the Caboclo shales of Branner are supposed to be Devonian, but thus far they have yielded no fossils. ${ }^{10}$

Economic geology of the Devonian.-The Devonian rocks contain the conglomerates of Parana from which the diamonds of that state are supposed to be derived.

The Caboclo shales of the interior of Bahia are available for the manufacture of Portland cement.

Elsewhere the Devonian beds are not known to contain anything of special economic importance.

\section{CARBONIFEROUS}

General observations.-Fossiliferous Upper Carboniferous beds are exposed on the lower Tapajos in the State of Pará, and on some of the smaller streams to the west of Tapajos, notably at Pedra do Barco and at Frechal, and also on the northern side of the Amazon on the rios Uatumá, Jamundá, and Trombetas. The geology and fossils are described by Chandless, Derby, Katzer, Ossat, and Tschennede.

All of the Brazilian rocks certainly known to be of Carboniferous age belong to the Upper Carboniferous and are confined to the areas mentioned. Other areas shown as Carboniferous on Katzer's map of Pará

\footnotetext{
- F. Katzer: Geologle des Unteren Amazonas Gebietes. p. 215.

${ }_{10}$ Geographical Journal, August, 1911, pp. 151, 258; Amer. Jour. Scl., vol, xxxl, June, 1911, p. 481 .
} 
lack confirmation. Dr. Lisboa ${ }^{11}$ credits Gonzaga de Campos with the report of Carboniferous extending south and west from the Tapajos area to Rio Theodoro just north of south latitude eight degrees, as indicated by dotted lines and the question-mark. Rocks in São Paulo and Paraná formerly called Carboniferous by Derby are now known to be of Permian age, while the diamond-bearing beds of Bahia referred provisionally to the Carboniferous by Branner have not yet yielded any fossils, and the age of those particular beds must still, therefore, be considered as doubtful.

In the Amazon region the Carboniferous rocks are shales, sandstones, and limestones; the fossils are found in the limestones and are all marine forms. At Itaituba the limestone is eight meters in thickness. The total thickness of these Carboniferous rocks in the Amazon basin is about 600 meters. No coal-bearing beds have been found in them.

The Bahia beds referred with doubt to the Carboniferous are the pinkish quartzites, sandstones, and conglomerates from which diamonds and carbonados are obtained. The rocks are gently folded over much of the diamond district and in some places they are closely folded and faulted. On account of their resistance to weathering they have a marked effect on the typography of the region in which they occur.

These quartzites, which are here tentatively referred to the Carboniferous, are of much geologic importance and interest aside from the fact that they are the rocks from which the diamonds and carbonados of Brazil are derived.

Bearing in mind that the Carboniferous age of the group of rocks here discussed has not been definitely settled, and that we have no paleontologic evidence of their age, it is nevertheless important to bring together such evidence as we have of the age, character, and distribution of this series.

In the State of Bahia the structural features of these beds, their relation to those above and below them, and their areal distribution are fairly well outlined in the papers of Branner, Crandall, and Williams. But between the Chapada diamantina of Bahia and the diamond fields of Minas Geraes is an area about which we have very little geologic information, and practically none that would enable us confidently to tie together with the necessary structural details the two regions. Certain facts, however, lend strong support to the theory that the diamond-bearing quartzites of the Bahia region are simply the northward extension of the diamond-bearing quartzites of Minas that are exposed and known to contain diamonds at Grão Mogol. These facts are here brought together.

110 problema do combustivel nacional. Rio, 1916, fig. xiv. 
It has been established beyond question that the diamonds and carbonados found in the Bahia region come directly from the false-bedded pink quartzites. ${ }^{12}$ That diamonds are found in the quartzites at Grão Mogol is equally well established. ${ }^{13}$ That the quartzites of Bahia are the same as those at Grão Mogol is far from being a new theory. It was probably first brought forward by Helmreichen, whose paper was written in 1843 and published in 1846. Helmreichen's theory was based on what he saw at Grão Mogol and on what he heard about the geologic conditions in Bahia. ${ }^{14}$ But, like many others, he supposed the quartzites of Grão Mogol were the old Paleozoic itacolumites of the Ouro Preto region. $\mathrm{He}$ adds that the following places are well known for the occurrence of diamonds:

1. Burity Quebrada, on the eastern spur of the Serra do Grão Mogol.

2. Cabeceiras do Corrego da Onça, on the western spur.

3. Corral de Pedra, on the eastern spur of the Serra do Peixe Bravo.

4. Serrinha Nova, between Rio Verde and Rio Pardo.

5. Boqueirão das Barreiras, western spur of Serra do Salto.

The places mentioned are all on or near the watershed that runs almost due north from Grão Mogol toward the city of Caiteté, in the State of Bahia, and seem to tie up the diamond-bearing quarzites of Minas with the diamond-bearing quartzites of the Chapada diamantina west of Paraguassú, Bahia:

It should be kept in mind, in dealing with the geology of this area, that there are several distinct series of quartzites thereabout that may readily be mistaken one for the other, both on account of their general resemblance and on account of their topographic prominence.

Economic geology of the Carboniferous.-The economic products of the Carboniferous of Brazil are limited to the diamonds and carbonados of Bahia and to the diamords of that part of northern Minas Geraes which is supposed to be correlated with the diamond-bearing quartzites of Bahia. The evidences of the origin of the diamonds and carbonados are given briefly under the head of "Carboniferous" and under the State of Bahia. The diamond-bearing beds are not all equally rich.

12 O. A. Derby : The geology of the diamond and carbonado washings of Bahia. Economic Geology, vol. i, November-December, 1905, pp. 134-142.

J. C. Branner: The economic geology of the diamond-bearing highlands of Bahia. Engineering and Mining Journal, May, 1909, pp. 87, 981, 1031.

Roderic Crandall : Notes on the geology of the diamond region of Bahia, Brazil. Economic Geology, May, 1919, vol. xiv, pp. 220-244.

${ }^{18}$ Virgil V. .Helmreichen: Geognostische Verkommen der Diamanten . . . auf der Serra do Grão Mogol. Wien, 1846.

H. Gorcelx : Gisement de diamants de Grăo Mogol. Bul. Soc. Geol. de France, vol. xif, pp. 538-545. Paris, 1884.

It V. von Helmrrichen: Geognostische Verkommen der Diamanten, etc., pp. 63-65: Wien, 1846. 
The opinion prevails in the diamond region of Bahia that the coarse conglomerates yield the largest diamonds and carbonados, while the fine grained sandstones yield only small ones.

It has been hoped that coal might be found associated with the Upper Carboniferous rocks of the Amazonas region, but thus far no such beds have been discovered, and the fact that the beds known are of marine origin does not encourage the hope of coal being found there.

Limestone is common in the Carboniferous rocks of the Amazonas region.

\section{PERMIAN}

General observations.-The Permian is par excellence the Brazilian series; rocks of Permian age cover large areas in Maranhão, Piauhy, Ceará, Bahia, Goyaz, Minas Geraes, São Paulo, Paraná, Santa Catharina, Rio Grande do Sul, and Matto Grosso, making an enormous total. Fossils from the Brazilian Permian are described by Unger, Brongniart, Carruthers, Cope, Derby, Lisboa, MacGregor, Osborn, Renault, Z. H. Scott, Seward, Solms-Laubach, David White, and Woodward.

The division of the Permian into Upper and Lower Permian on the geological map is based on what appears to be a clearly defined and easily recognized distinction. In northern Brazil, Small shows a well marked unconformity between the Upper Permian, which is exposed over most of eastern Piauhy, and the Lower Permian in the Serra Grande that lies along the boundary between Piauhy and Ceará. The only uncertainty about this classification-and it is a serious one-is that the Serra Grande series has never yielded any fossils, and its reference to the Lower Permian is therefore in doubt. In southern Brazil the Upper Permian is characterized by the fossils Stereosternum and Mesosaurus and by siliceous beds and concretions, while the Lower Permian contains the Glossopteris flora, the coal beds, and in some places in São Paulo and Paraná it contains well marked evidences of glaciation. The evidences of glaciation are best described by Woodworth, the title of whose book is given in the bibliographic list under São Paulo. Thus far, unquestioned evidences have been found only in the States of Santa Catharina, Paraná, and São Paulo; but Dr. Lisboa found in Minas Geraes what seem to be evidences of glaciation in the region between Rio Borrachudo and Rio Abaeté. ${ }^{15}$ In São Paulo and from there southward the Permian beds dip gently westward, while characteristic Permian fossils, notably Stereosternum tumidum, ${ }^{16}$ found near Villa Rica, Paraguay, and Productus and Spirifer

\footnotetext{
t5 M. A. R. Lisboa : The occurrence of faceted pebbles on the central plateau of Brazll. Am. Jour. Sci., January, 1907, vol. xxili, pp. 9-19.

${ }^{16}$ Frech in Lethea Geognostica, Th. I, 2 Bd., Lief 3, p. 460.
} 
poststriatus, the last two from mountains on the Matto Grosso frontier, ${ }^{17}$ lead to the conclusion that the Permian probably underlies all of the Paraná Valley west of Paraná and Santa Catharina, and that some of the limestones of southern Matto Grosso, called "Bodoquena" by Dr. Lisboa, may yet prove to be of Permian age.

The rocks of the Permian in Brazil seem to be mostly sandstones and shales slightly disturbed, but they include extensive beds of limestoneall of them cut here and there by eruptive dikes. In São Paulo, Paraná, and Santa Catharina the Lower Permian contains glacial till with striated boulders: The glaciated Permian beds in the States of São Paulo and Paraná are described by Prof. J. B. Woodworth, to whose paper the reader is referred. ${ }^{18}$ The base of the Permian is fairly well located across the State of São Paulo, but north of the São Paulo-Minas frontier the eastern margin of the series has been tentatively located with difficulty and with doubt. The evidence of the northward extension of the beds recognized in São Paulo as Permian are here brought together. It is assumed that the faceted boulders found by Dr. Lisboa in the region between Rio Borrachudo and Rio Abaeté may have come from Lower Permian glacial beds, as he suspected $;^{19}$ for Dr. Lisboa dístinctly repudiated the idea of Pleistocene glaciation in connection with these boulders, and that the region in which the faceted pebbles were found had been glaciated in Permian times was definitely taken into consideration by him. After mentioning the Permian deposits of southern Brazil, he adds:

"But in the central region in the great basin of the upper São Francisco they (the Permian beds) have never been identified. So far as the geology of the region is known, however, there is nothing positively against this hypothesis (of Permian glaciation), and any undoubted observation that supports it will be of great geologic importance for this country." ${ }^{20}$

Thus Dr. Lisboa was the first geologist to suspect and to suggest the full meaning of the Permian data in the State of Minas Geraes.

Additional notes by Dr. Francisco de Paulo Oliveira on the geology of the region between Pitanguy and the lead mines of Ribeirão do Chumbo, an affluent of Rio Abaeté; are of interest in this connection ;21 at page 48 he says:

\footnotetext{
17 J. V. Slemiradsk1: Geologische Relsebeobachtungen in Stidbrasilien, p. 39.

18 J. B. Woodworth : Geological expedition to Brazll and Chile. Bul. Mus. Comp. Zool., vol. lvi, no. 1. Cambridge, Mass., 1912.

10 M. A. R. Lisboa : The occurrence of faceted pebbles on the central plateau of Brazil. Am. Jour. Sel., January, 1907, vol. xxill, pp. 9-19.

* Miguel A. R. Lisboa: Occorrencla de seixos facetados no planalto central brasileiro. Annaes da Escola de Minas de Ouro Preto, no. 8, pp. 25-39. Ouro Preto, 1906.

${ }^{21}$ Francisco de Paula Olivelra : Exploraçăo das minas de galena do Ribelrăo do Chumbo. Annaes da Escola de Minas de Ouro Preto, no. 1, Rio de Janeiro, 1881, pp. 35-94.
} 
"Upon the shales rest the red sandstones like those near Abaeté on the banks of the Borrachudo and the Chumbo. They belong to a formation above the clay shales. Between the serra do Capacete and the banks of the Indais there are rolled stones on the tops of the mountains that show the great action of water in this part of the province. . . . Finally, intercalated with the clay shales are enormous beds of limestone, and above them ferruginous conglomerates. These conglomerates are seen near the village of Dores along much of the road leading from the village of Carmo to the town of Dores."

The conglomerates and water-worn rocks mentioned by Dr. Oliveira are in the region in which Dr. Lisboa later found the faceted pebbles.

Dr. Antonio Olyntho, speaking of the watershed between the Abaeté and the Borrachudo, mentions "uma argilla branca com caprichosos arabescos." 22

In connection with the subject of Permian glaciation in Minas the following is of especial interest: The French geologist Francis de Castelnau, who went from Pitanguy to Bom Despacho, in the State of Minas, in January, 1844, made the following notes on the geology: After leaving the city of Pitanguy, he crossed the Rio Pará and passed fazenda Santa Cruz. He then says: ${ }^{23}$

"On the 22d we made three leagues in the same direction. The formation is clay shale, probably resting upon gneiss. One league from Santa Cruz (fazenda) one begins to find scattered about a great quantity of granite blocks that look like erratics; they can not come from slides ('d'eboulement') from the mountain, for there are none in the vicinity. Never having seen anything of the kind in the whole course of our expedition, it is only with doubt that we refer the rocks in question to such an origin; it is very likely that they owe their origin to some local phenomenon. . . . The formation in general is clay shale (schiste), gray, ochreous, and reddish, dipping to the east, but half way between Trigueira and Bom Despacho the ground is covered by a sheet (coulée) of rose-colored granite which looks like a kind of syenite. On both sides of the road one sees over the plain a considerable quantity of granite blocks that have the appearance of being erratic. The land is rather flat on the whole, and one sees these blocks on the steep slopes right away up to the hilltops."

These observations by Castelnau must be regarded as especially suggestive and valuable in connection with the subject of Permian glaciation in Minas. A little farther southwest, on the road between Formiga and Bambuhy, Pohl noted red and yellow clays and clay shales. ${ }^{24}$

Mr. H. E. Williams, of the Serviço Geologico do Brasil, in a private letter dated August 26, 1918, writes :

22 Viagem aos terrenos diamantiferos do Abaete. Annaes da Escola de Minas, no. 4, p. 141.

29 Francis de Castelnan : Expedition dans les parties centrales de l'Amerique du Sud. Historfe du Vorage, vol. 1, pp. 276-278. Parls. 1850.

24 Joh. Em. Pohl : Beytrkge zur Gebirgskunde Brazlliens. Wien, 1832. 
"Mr. Draper has been up about Areado, and, following down the Pindahybas, he and Mr. Pontie found an exposure of conglomerate four or five meters thick with big boulders of granite. Draper calls it the Dwyka. This is not far from where I found a small exposure of the same nature south of Areado. I have word of similar beds of conglomerate on the north side of the Caboclo above the Fabrica de Oliveira."

Mr. F. W. Bunyan, who visited both regions, tells me that the rocks exposed at the junction of Rio das Velhas and Rio São Francisco are remarkably like the Permian till beds at Itarare and Faixina, in southern São Paulo. ${ }^{25}$ This observation was made without any suggestion or question by me. Upon receiving this information in regard to a particular locality, I looked up the notes of other observers made at that place with the following results:

Dr. Theodoro Sampaio, who visited this place in 1879 , says he found on the sides of the Serra de Manga "um schisto avermelhado que aqui parece constituir o embasamento do planalto e muito seixo rolado." 26

At Jequitahy, a village nine leagues east of the mouth of Rio das Velhas, Derby found "a pudding-stone containing well worn boulders of quartz, jasper, gneiss, quartzite, and amorphous limestone, some of them of great size." 27

At the mouth of Rio das Velhas, James W. Wells, an English engineer, observed "a sheet of unstratified clay, interspersed with pebbles and boulders overlying the rock in places. . . . The boulders are usually masses of a kind of greenstone . . . and they are entirely foreign to the rocks they often rest upon." 28

The demarcation between the Lower and the Upper Permian seems to be well defined in the State of São Paulo, but north of there, for lack of fossils, no separation can be made save on the hypothesis that the same division probably continues northward into Minas. A comparison of the order of the beds as given for the rocks by Dr. Oliveira in the article cited above ${ }^{29}$ shows the presence of a bituminous shale that brings to mind the Iraty bituminous shale so characteristic of the base of the Upper Permian in São Paulo and Paraná. The order of the rocks as given by him is :

\footnotetext{
${ }^{25}$ Letter of December 19, 1917.

28 "O Rio de Săo Francisco e a Chapada Diamantina," p. 89.

$z$ o. A. Derby : Reconhecimento geologico de Valle do Săo Francisco, p. 5 do annexo ao Relatorio de W. Milnor Roberts . . . sobre o exame do Rio São Francisco. Rio de Janeiro, 1880.

Also in the Archivos do Museu Nacional, vol. iv, p, 102.

28 J. W. Wells : Three thousand miles through Brazil, vol. ii, p. 373. London, 1886.

29 Annaes da Escola da Minas, no. 1, p. 53.
} 
5. Ferruginous conglomerates and sandstones.

4. Clay shales.

3. Bituminous shales.

2. Limestones.

1. Shales at the base.

Unfortunately he does not tell where this bituminous shale was seen. A bituminous shale is also reported by Dr. Lisboa in Maranhão.

These notes and observations are all extremely interesting and suggestive, and it is hoped that the evidences of glaciation and of the Permian age of the beds in question may soon be examined and definitely settled by a geologist thoroughly familiar with glacial phenomena.

The evidences of the structural relations of the great limestone beds of the upper Rio das Velhas to the Permian beds to the west of them are not abundant, but they seem to be conclusive. Eschwege, whose obser-
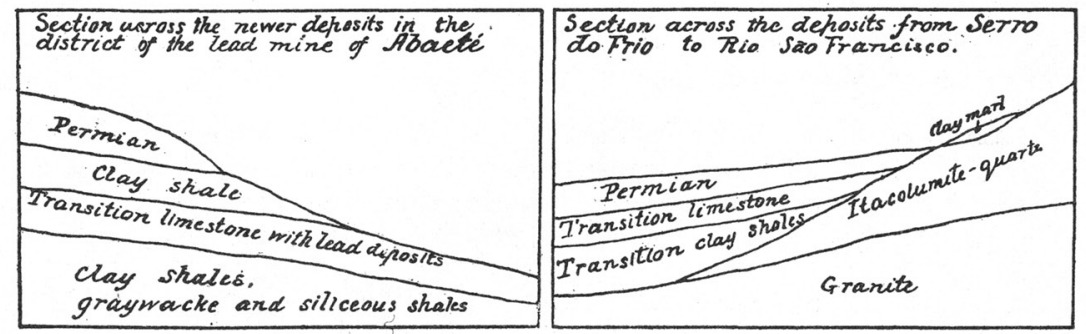

FIGURE 2.-Two Sections from Eschwege's Beiträge aur Gebirgskunde Brasiliens

The names in the original are here translated, and the greatly exaggerated vertical scale is reduced to two-fifths of the original.

vations and judgment must be accepted in all seriousness, gives two sections in which he shows the relative position of the rocks of the Rio das Velhas and of those at the lead mines of Abaeté west of Rio São Francisco. These two sections are here reproduced, ${ }^{30}$ and attention is directed to his clear conviction that the limestones on both sides of the São Francisco underlie or form parts of the Permian beds. Whether the limestones and his transition ("Uebergangsthonschiefer") and other shales really make part of the Permian is a question that can not be settled at present. Eschwege's own views seem to be expressed in a footnote at page 488 of his Beiträge zur Gebirgskunde. He there says:

"One must also not forget the wide-spread distribution of the transitional areas of clay shales and limestones in the province of Minas Geraes, in the

${ }^{30}$ W. L. von Eschwege: Beiträge zur Gebirgskunde Braziliens. Berlin, 1832 (plate no. 3 ). 
region of Rio São Francisco and in that of the Rio Tieté, in the province of São Paulo."

From this it is inferred that he means to correlate the clay shales and limestones of the upper São Francisco with what we now know to be the Permian beds of São Paulo.

Gerber leaves no doubt about his views in regard to his "transition formations," for he says : ${ }^{31}$

"The greater part of northwestern Minas, the basins of the Rio São Francisco and Rio das Velhas from Lagoa Santa belong to this (transition) division, whose principal representative is the traumatic shale. The beds of this formation are almost entirely horizontal, and at divers places there are interbedded with them limestones whose general masses are spherical [he probably means lenticular], and exhibit horizontal stratification."

Though Lund spent many years at Lagoa Santa, in Minas, near the base of the Permian, the only expression of his that seems to relate to this subject is where he speaks of a hill at whose south base were great quantities of limestone blocks. He adds:

"I mention this case, by the way, only because it corresponds with many others that I have seen, and because it shows that a great inundation that covered this part of Brazil with its last layer of earth, and that dislocated enormous rock fragments, had a north-south direction in these regions." 82

In regard to the rocks of the Serra do Maquiné, which is on the left side of Rio das Velhas, some thirty kilometers south of Curvelho, he says that "at the base of the mountain one finds the same rock as on the surrounding plain-transition clay shales alternating with siliceous shales dipping eastward ten degrees (page 63). The limestone in which Maquiné cave occurs "alternates with beds of clay or siliceous shales with gypsum crystals. These (shale) beds are generally not so thick as the limestones." ${ }^{33}$

Owing to his exploration of the Rio das Velhas, the observations of Em. Liais on the geology along that stream are worthy of especial attention. He says : ${ }^{84}$

"Mais si maintenant, en descendant la vallée du San-Francisco, nous accompagnons ces calcaires a partix de ceux qui se trouvent ainsi dans le haut de son bassin entre l'Abaéthé et le Rio das Velhas, nous les verrons se présenter d'une manière identique quant a leur structure, leur aspect, leur grottes, leurs puissance et leur distribution dans toute l'extension du cours du fleuve, et ils $y$ forment comme une espèce d'horizon géologique très facile à suivre et à accom-

\footnotetext{
Henrique Gerber: Noçoes geographlcas e administrativas da protincia de Minas Geraes. Relmpressão da 1a ed. de 1863. Hảnnover, 1874, p. 19.

${ }_{22}$ P. W. Lund: Grutas calcareas, etc. Annaes da Escola de Minas, no. 4, p. 12. Rlo de Janeiro, 1885.

3. W. Lund: Annaes da Escola de Minas, no. 3, pp. 63-64. Rio de Janelro, 1884.

a Emmaṇuel Liais : Climats, géologie, fauna, etc., du Brésil. Parls, 1872, p. 179.
} 
pagner. Constamment, nous retrouverons ces mêmes calcaires des deux côtés de la vallée du San-Francisco, et ils apparaissent souvent à la bas d'une dépôt de grès et de schiste argileux à couches presque horizontales, qui repose sur eux et dans lequel la dénudation a creusé le bassin du fleuve et de ses affluents."

Notes made by Dr. Antonio Olyntho at Lapa do Chumbo, five kilometers southwest of Sete Lagoas and close to the margin of the Permian, ${ }^{35}$ tell of "um veeiro de quartzo encaixotado entre camadas de schisto, tudo intercalado em uma montanha calcarea," and "As camadas de schisto têm para cima a altura de 3 a 4 metros, e acima d'elles vêm a

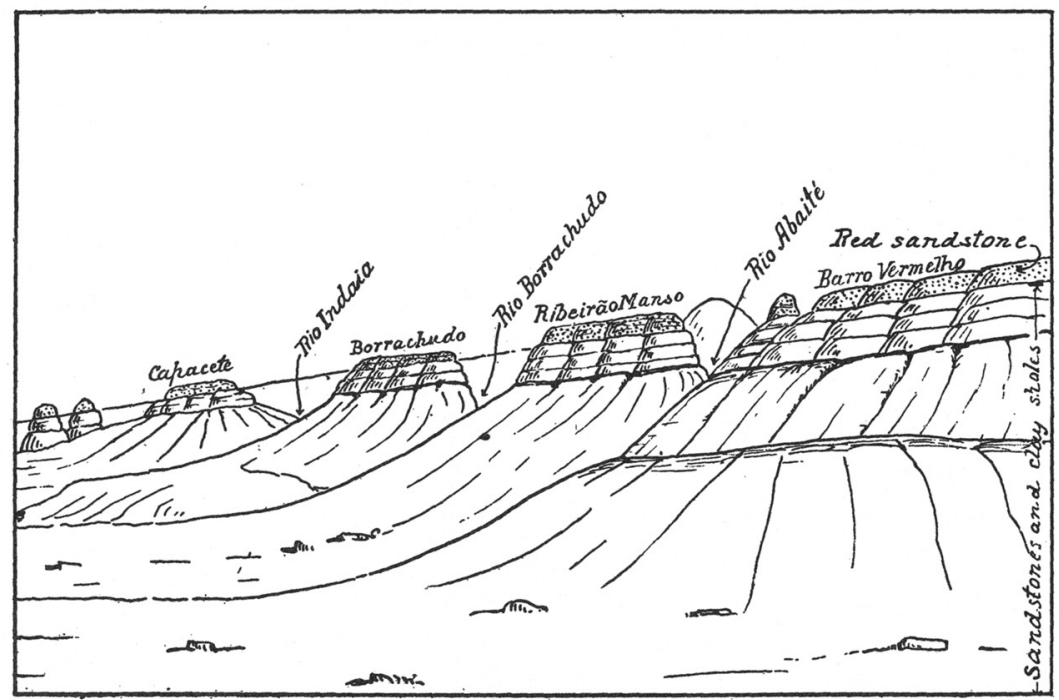

Figure 3.-The Mountains of the Diamond District of Abaité

The view is taken from near Toldas, six leagues east of Serra do Barro Vermelho. After P. Claussen.

montanha calcarea." These exposures leave no doubt about the shales and the limestone being interbedded.

This interbedding of the shales and limestones is noted by all the geologists who have crossed the basin of the upper Rio São Francisco, especially on rios Indaia, Borrachudo; Abaeté, and on the São Francisco. ${ }^{36}$ Particularly impressive and enlightening are the section given by Claussen, which is here reproduced, ${ }^{37}$ and his observations and conclusions in

35 Antonio Olyntho dos Santos Pires: Viagem aos terrenos diamantiferos do Abaeté. Annaes da Escola de Minas, no. 4, pp. 145, 146. Rio de Janeiro, 1885.

${ }^{36}$ See Lisboa, Oliveira, Antonio Olyntho, and Claussen.

${ }^{37} \mathrm{P}$. Claussen: Notes géologiques sur la province de Minas Geraes. Bul. Acad. Royal de Bruxelles, vol. viii, no. 5, pl. 1, Brussels, 1841. 
regard to the Permian beds, which he called the "terrain de transition" (page 7).

Claussen's section represents the geology right across the Permian basin, including the whole region between Serra do Capacete and the Serra do Barro Vermelho. Of the "terrain de transition" he says (page 17 ):

"Le terrain calcareux de transition est composé de couches a peu pres horizontales de phyllades argileux, petrosiliceux et macignos. ${ }^{88}$ Elles contiennent, spécialement dans leurs assises inferieurs, des couches puissantes de calcaire noir et gris. Presque toutes les inégalités de ce terrain sont dues aux effets de la dénudation, et cela donne um aspect tout particulier au pays, en formant de grands plateaux sur des montagnes cotoyées de terrasses. . . . Ce terrain constitue à peu près le tiers du sol de la province de minas Geraes."

And it should be remembered that Claussen lived in Minas some twenty years (page 1), and that he traveled widely, while his paper showed that he was a careful and discriminating geologist.

On the east side of the Rio São Francisco these limestones and interbedded shales, here referred to the Permian, extend from Santa Luzia in Minas northward to about 50 kilometers north of 14 degrees south latitude-that is, to a point about 75 kilometers northeast of the city of Carinhanha. On the west side of the São Francisco the limestones end a few kilometers north of Carinhanha. ${ }^{39}$

General conclusions.-The Permian beds have been definitely determined from fossils, and traced out stratigraphically from the southern part of Rio Grande do Sul to the northern part of São Paulo. North of São Paulo the base of the series has been approximately located from the notes of geologists as far as 14 degrees south latitude on Rio São Francisco, while in the Chapada diamantina east of the Rio São Francisco rocks believed to belong to the Permian have been located by the writer and his assistants, Crandall and Williams, over the region between 12 and 14 degrees south latitude.

In the southern states several divisions have been recognized locally, but two divisions are readily identified by the fossils Stereosternum and Mesosaurus and by the flint beds found in the upper, and by the Glossopteris flora and the glacial beds found in the lower division. In northern Brazil the upper division is characterized by the fossils Psaronius and Sigillaria, but no fossils have yet been found in northern Brazil in what are referred tentatively to the Lower Permian.

\footnotetext{
${ }^{38}$ Macigno is defined by Littré as a rock composed of quartz, mica, clay and iron hardened by a calcareous cement. Vilanova y Piera says it is a hard sandstone of feldspar, mica, cemented by a siliceous marl, sometimes green, sometimes black.

${ }^{30}$ It should be noted that the Permian limestones do not connect with those at Bom Jesus da Lapa. The Bom Jesus exposure is entirely isolated.
} 
The Permian rocks are sandstones, clay shales, and limestones cut at many places by eruptive dikes. For the most part they are approximately horizontal, and they seem to be of land or fresh-water origin, though what are supposed to be brackish water fossils have been found in them at Rancho Grande and Lageadinho, on Rio Caçador near the old Iraty colony, and Mojolinho and at several other places, all of them in the State of Paraná. ${ }^{40}$

Topographically the upper Permian beds form vast stretches of table lands that are deeply eroded by streams and supporting a sparse vegetation.

Though fossils have been found in the Permian in the north and south of Brazil, none has yet been identified from the great area covered by these rocks in the State of Minas Geraes. The fact that poorly preserved but unrecognizable fossils are reported from this region by both Claussen and Liais leads to the reasonable hope that a careful search for them may yet be rewarded with unquestionable evidence of the age of the deposits and of the conditions under which they were laid down.

Prior to 1840 Claussen found the impression of a univalve shell in sandstone in the region of the upper Rio Abaeté, but he was unable to identify it, and it was deposited by him in the National Museum at Rio de Janeiro. ${ }^{41}$ Liais also reports fossils in this region, and as his account of them is the fullest and almost the only one we have, it is given here at some length. ${ }^{42}$

"A short distance from Pitangul and near Abbadie I have seen nodular and bituminous limestones with undeterminable traces of fossils, among which I could distinguish small lenticular bodies from two to three millimeters in diameter, which seemed to me to belong to the foraminifera, although the alteration prevents my being able to say so definitely. Near Lapa dos Urubus, on the right side of the Rio das Velhas, a short distance below the confluence of the Parafina, I have seen a marble with a white ground, the beds standing on end and cut by reddish and gray veins. On polishing pieces of this marble I have recognized fragments of univalve shells, but quite undeterminable. In another bituminous limestone of the same horizon I have found traces of cirriped crustacea more recognizable and belonging to the genus Pollicipes. which indicates a marine origin for these limestones and places them in the secondary epoch.

"In the macignos, on the borders of Rio Abaeté, other fossils are found which also show the formation in question to be marine. There are impressions of the genus Ostrea. M. Claussen has already mentioned them, and in

\footnotetext{
40 Euzebio de Paulo Oliveira: Geologia do Estado do Paraná, pp. 130-131. Rio de Janeiro, 1916.

1. P. Claussen: Notes géologiques sur la province de Minas Geraes. Bul. de l'Acad. Royale de Bruxelles, vol. viii. no. 5, p. 9. Bruxelles, 1841.

${ }^{2}$ Emmanuel Liais : Climats, géologie, etc., du Brésil, pp. 147-148. Paris, 1872.
} 
my trip on the upper São Francisco I have seen an impression of an oyster of good size (d'assez grande taille) and remarkable not only for the thickness of its shell, but also for the great prominence of the spire, which places it close to the grypheas. I shall give this species the name Ostrea abcethensis from the name of the river basin in which I found it. At the same place I noted a great number of impressions of the same species.

"In the macigno sandstones I have likewise seen less well preserved impressions of divers polyps and fragments of undeterminable univalve shells of considerable size. . .

"Everything shows, therefore, that the metamorphic limestones of the province of Minas Geraes and belonging to the stage of which we speak are not older than the Cretaceous."

Mr. Derby, in referring to these statements, expresses the opinion that Mr. Liais erred in the identification of the fossils. ${ }^{48}$

Whether Liais erred or not, his notes and those of Claussen clearly point out the region in which fossils may be sought and to which field geologists should give their careful attention. If Liais is correct in the identification of his fossils, there is an area of Cretaceous rocks in the region where he found them, but it does not necessarily follow that there are no Permian beds beneath them.

Economic geology of the Permian.-The coal beds of Paraná, Santa Catharina, and Rio Grande do Sul are among the important economic products of the Permian in Brazil. Here, too, belong the Iraty bituminous shales of the southern states. The Permian limestones are widespread and are likely to be a source of national importance for the manufacture of Portland cement.

It seems quite possible that some of the important occurrences of diamonds in Brazil are in the glacial beds at the base of the Permian.

\section{TRIAESIO}

The Triassic rocks, so far as they have been recognized in Brazil, are known as the Botucatú, a name given them by Gonzaga de Campos for the Serra de Botucatí, in the State of São Paulo. They are soft reddish sandstones, usually horizontal, but more or less faulted, and associated with sheets and dikes of diabase eruptives. These beds attain a maximum thickmess of 500 meters or more, but averaging from 100 to 300 meters. They cover large areas in the States of São Paulo, Paraná, Santa Catharina, Rio Grande do Sul, Matto Grosso, and Goyaz, and probably also in Piauhy and Maranhão.

The only fossils thus far reported from the Triassic of Brazil were

\footnotetext{
Ls Reconhecimento geologico do Valle de São Francisco. Por O. A. Derby. Pagina 8 do annexo ao Relatorio de W. Milnor Roberts sobre o Rio Săo Francisco. Rio de Janeiro, 1880.
} 
found near Santa Maria da Bocca do Monte, in the State of Rio Grande do Sul, and at São José do Rio Preto, in São Paulo. (See Smith Woodward and R. Von Ihering.)

\section{CRETAOEOUS}

General observations.-Fossiliferous Cretaceous beds are found in a narrow belt along the coast of Parahyba, Pernambuco, Sergipe, and Bahia. In the States of São Paulo, Paraná, Santa Catharina, Rio Grande do Sul, and in southern Matto Grosso Lower Cretaceous beds (named Baurú by Gonzaga de Campos) cap the hills and cover large areas. The only fossils found in the Baurú beds suggest that they correspond to the Wealden of Europe. (See Pacheco.) In the Serra do Araripe, along the southern frontier of Ceará, Cretaceous beds contain well preserved fossil fishes. The rocks in the Serra do Araripe are nearly horizontal sandstones and limestones that extend into the adjacent States. (See Jordan and Branner.)

The areas in Matto Grosso colored as Cretaceous on the map-the Parecis sandstones-are not yet certainly known to be such, for no Cretaceous fossils have been found in them. The views of Euzebio de Paulo Oliveira are followed. ${ }^{4}$

The following authors have written on the Cretaceous of Brazil:

$\begin{array}{lll}\text { Agassiz } & \text { Hyatt } & \text { Oliveira, E. (Matto Grosso) } \\ \text { Alport } & \text { Jordan } & \text { Rathbun } \\ \text { Branner } & \text { Loriol } & \text { White, C. A. } \\ \text { Cabrillac } & \text { Marsh } & \text { Williston } \\ \text { Cope } & \text { Mawson } & \text { Woodward } \\ \text { Douvillé } & \text { Morris } & \end{array}$

Economic geology of the Cretaceous.-In the State of Sergipe Cretaceous limestones are abundant and are available both for building stones and for the manufacture of lime and of Portland cement.

In the Chapada do Araripe the Cretaceous contains important beds of limestone. Limestones of local importance also occur in the Cretaceous of Pernambuco and Parahyba.

\section{TERTIARP}

General observations.-Beds of Tertiary age occur in Acre, where they are fresh-water or land deposits. In Amazonas fossils show some of the Tertiary beds to be brackish water deposits. In Pará, Maranhão, and Rio Grande do Norte fossils show the Tertiary deposits to be of marine

\footnotetext{
4 Reconhecimento geologico do noroeste de Matto Grosso por Euzeblo Paulo de Oliveira, pp. 31, 69. Rlo de Janeiro, 1916.
}

XVI-Buld. Grol. Soc. A 
origin, and it is assumed that the corresponding sediments forming a similar belt in Ceará are also marine. Marine fossils have been found also in the Tertiary beds in Parahyba, Pernambuco, Alagoas, and Bahia, and it is supposed that some of the coastal sediments in Sergipe, Espirito Santo, Rio de Janeiro, and along the coast to the south are likewise Tertiary. In Rio de Janeiro, São Paulo, and Minas are extensive Tertiary lake deposits, and near Ouriçanguinhas, Bahia, lake deposits overlie the marine Cretaceous.

The Tertiary fossils have been described by-

$\begin{array}{lll}\text { Alport } & \text { Jenkins } & \text { Rathbun } \\ \text { Arnold } & \text { Jordan } & \text { Reinhardt } \\ \text { Conrad } & \text { Jones } & \text { von Ihering } \\ \text { Cope } & \text { Krasser } & \text { Warming } \\ \text { Dall } & \text { Lacerda } & \text { White, C. A. } \\ \text { Ethridge } & \text { Lund } & \text { Winge } \\ \text { Gabb } & \text { Lutken } & \text { Woodward } \\ \text { Gervais } & \text { Morris } & \\ \text { Gürich } & \text { Quatrefages } & \end{array}$

Economic geology of the Tertiary. -In the coastal belt from Bahia northward the Tertiary sediments are liable to be of value at many places as sources of underground water. At several places in the States of Bahia and Alagoas the Tertiary beds include bituminous shales that may eventually be of economic importance. In Minas and São Paulo the Tertiary lake deposits also contain lignites and bituminous shales. These shales were formerly used at Taubate for the manufacture of gas. Clays for the manufacture of bricks, tiles, sewer pipes, and common pottery are abundant in the Tertiary. See also under Amazonas.

\section{Petrography}

Under the head of petrography nothing need be said of the old writers whose geologic classifications were based on lithology. All of the early writers on Brazilian geology used terms that have long been discarded. Most of the modern work on this branch of geology was done by Hussak, whose papers are given under the States of Minas, São Paulo, Rio de Janeiro, and Goyaz. Following are the modern petrographers who have written on Brazilian rocks:

Bauer, H. E.

Derby

Gill (Fernando de Noronha)

Gorcelx

Gràeff

Gumbel (Fernando de Noronha)

\author{
Hovey \\ Hussak \\ Iddings \\ Kemp \\ Laerne \\ Machado
}




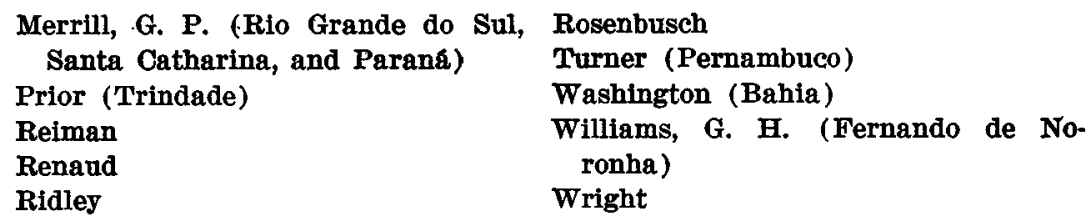

OUTLINES OF THE GENERAL AND ECONOMIC GEOLOGY AND BIBLIOGRAPHY BY States

\section{GENERAL OBSERTATIONS}

In the text the states are arranged alphabetically.

Those who have occasion to use the geologic map of Brazil are also liable to have occasion to use what has been published on the geology of the individual states or of other limited areas. For that reason there is given a partial bibliography of the geology of each of the states.

Under each state is given a brief outline of its general geology, and this outline is followed by a short statement of what is known of its economic geology. If the information given is often very meager, it is because only meager information is available.

In the bibliographic lists the titles are arranged alphabetically by authors.

All the papers referring to the geology of the various states are not given in the state lists for the reason that many of them are merely repetitions, in one form or another, and treat of the geology only at second or third hand. The idea of giving the titles at all is partly to show the authorities for some of the data used in the geological map of Brazil and partly to enable those who wish to consult the original authorities to find them readily and to obtain fuller information if it should be required.

If additional titles are wanted, most of them can be found in the author's bibliography of the geology of Brazil, published in the Bulletin of the Geological Society of America, volume 20, pages 1-132, 1909. It should be remembered, however, that many valuable papers have appeared since that list was published. Unfortunately, many of the contributions to the geology of Brazil have appeared only in the daily papers in Rio de Janeiro and are therefore difficult of access to persons outside of that city.

The island of Fernando de Noronha is politically a part of the State of Pernambuco, and for that reason the titles referring to that island are included in the State of Pernambuco and are followed by the word (Fernando) in parentheses, except when the title makes clear its relation to that island.

The Brazilian island of Trindade, in latitude $20^{\circ} 30^{\prime}$ south, $29^{\circ} 25^{\prime}$ 
west, belongs to the Federal Union, and the few titles relating to that island are given under Rio de Janeiro, in which the federal district is also located.

\section{AORE}

Previous investigations.-Our knowledge of the geology of the territory of Acre is derived almost exclusively from the notes of William Chandless, given in his account of explorations of the upper Purus and the Aquiry. A little sidelight may be had on the geology from the notes of Evans, Church, Keller, and Euzebio de Oliveira on the geology of the falls of the Madeira River. An important contribution is the discussion by Gürich of the age of the deposits along the upper reaches of the Purus. Those beds had been referred by Agassiz to the Cretaceous, but Gürich shows conclusively that they are late Tertiary.

General geology.-With the possible exception of the foothills in the western and southwestern parts of the territory, its entire area is covered by late Tertiary deposits-mostly undisturbed sands and clays through which wind sluggish streams. The entire area is covered by dense forests and there are no roads. The population is sparse and all travel is by water.

There is no doubt about there being wide zones of alluvial deposits along the larger streams, but there is very little or no available information on the subject.

In the southwestern corner of the territory the frontier seems to be in the foothills of the Andes, but nothing is known of the ages of those rocks, and that area is therefore left blank on the map.

Economic geology.-Nothing trustworthy has been published on the mineral resources of Acre territory. Gold has been reported from some of the streams heading in the hilly regions in the west and southwest.

\section{Bibliography of the Geology of Acre}

W. Chandless : Ascent of the River Purus. Journal of the Royal GeographIcal Sociéty, volume XXXVI, pages 86-118. London, 1866.

W. Chandess : Notes on the River Aquiry, the principal affuent of the River Purus. Journal of the Royal Geographical Society, volume XXXVI, pages 119-128. London, 1866. Abstract in Proceedings of the Royal Geographical Society, volume XI, 1866-7, pages 100-102.

W. Chandess : Apontamento sobre o Rio Aquiry, aflluente do Rio Purus. Annexo (lettra n) ao Relatorio do Ministro de Agricultura, etc., pages 1-6. Rio de Janeiro, 1866.

W. Chandless : Notes of a journey up the River Jurua. Journal of the Royal Geographical Society, volume XXXIX, pages 296-311. London, 1869.

Grobar Earl Churoh: The ronte to Bolivia via the River Amazon. $\mathbf{8}^{\circ}, 216$ pages. London, 1877. 
J. W. Evans: The rocks of the cataracts of the River Madeira, etc. Quarterly Journal of the Geological Society, volume LXII, pages 88-124. London, 1906.

G. GürroH : Gryposuchus Jessei, ein neues schmalschnau ziges Krokódil aus den, etc. Jahrbuch der Hamburgischen Wissenschaften Anstalten, volume XXIX, 1911, pages 59-71. Hamburg, 1912.

Franz Kriler: The Amazon and Madeira rivers. Sketches and descriptions from the note-book of an explorer. By Franz Keller, engineer. $4^{\circ}, \mathbf{x v i}+$ 177 pages. New York, 1874. Notes on the geology.

Guzgrio Patro de Oliveira : Expedição Scientifica Roosevelt-Rondon. Annexo I, Geologia. Rio de Janeiro, 1915. (Estrada de Ferro Madeira-Mamoré, paginas $61-65$.)

\section{ALAGOAS}

Previous investigations.-Very little has been published on the geology of the State of Alagoas. Of the three papers by Branner the most comprehensive is the one on the geology of the coast of the State, published in the Annals of the Carnegie Museum. The paper by D. S. Jordan on the fossil fishes from Riacho Doce definitely determined the Eocene age of the coastal sediments of that state for the first time. Branner's paper on the oil-bearing shales of the coast includes about all that is known of the Tertiary of the state. A few notes in Hartt's Physical Geography and Geology of Brazil, and a few by Burlamaqui on the shales at Camaragibe, together with the papers above mentioned, contain all that has been published on the geology of Alagoas.

The geology as given on the author's map of Brazil is taken almost exclusively from his own personal observations, supplemented by the notes of his assistant, Roderic Crandall, who crossed the state from Penedo to Maceio in 1908.

General geology.-Archean rocks are exposed over the greater part of the interior of the State of Alagoas. Tertiary sediments form the seacoast, while between is a triangular area of old Paleozoic and Permian beds. Starting at Traipú, on the Rio São Francisco, the eastern margin of the Archean area runs in a northeasterly direction past the northerm end of Lagoa Manguaba, Albuquerque, Passo, and Porto Calvo, and so on into the State of Pernambuco near Barreiros. To the north and west of this line everything is Archean except some isolated hills of sedimentary rocks near the falls of Paulo Affonso.

Lapping back against this Archean area is a series of Paleozoic rocks of unknown age. This series is exposed where it is cut across by the Rio São Francisco from near Traipú to southeast of the town of Collegio. The contact of the sedimentary beds with the granite seems to be at Talhado near Traipú.45 This Paleozoic area forms an acute triangle whose

« R. F. Burton : Explorations, etc., vol. 11, p. 423 . London, 1869. 
eastern extremity is probably near the north end of 'Lagoa Manguaba. Resting back against these Paleozoic rocks is another wedge-shaped area of red Permian sandstones and shales which crop out at the city of Penedo, on the Rio São Francisco, and dip gently toward the ocean.

Along the railway between Piranhas and the falls of Paulo Affonso are several outliers of sedimentary rocks that are here tentatively referred to the Permian. These outliers cap the hills on both sides of the railway and extend to the northeast as far as Buique, in the State of Pernam-

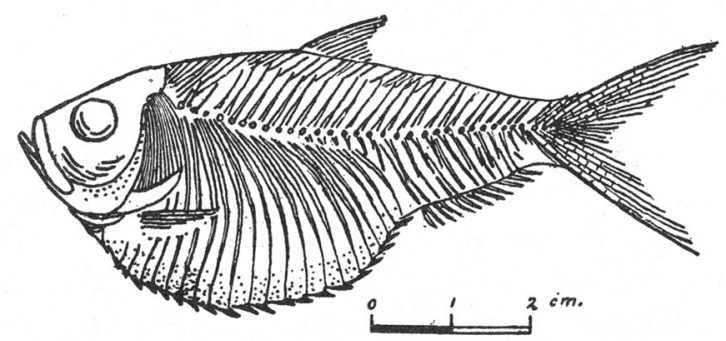

Ellimma branneri Jordan

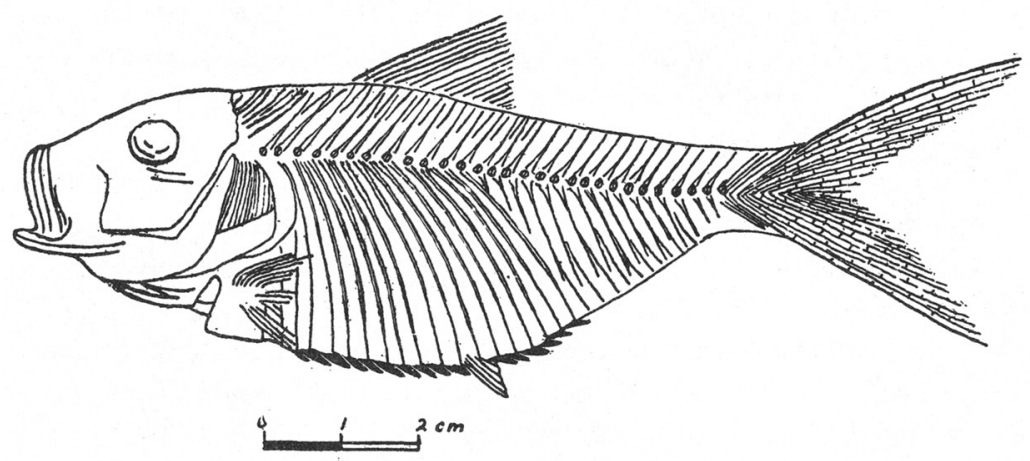

Ellimma riacencis Jordan

Figure 4:-Eocene Fishes from the bituminous Shales at Riacho Doce, State of Alagoas

buco. Along the entire Alagoas coast Tertiary sediments form a series of bluffs that reach a height of 100 meters above the sea. The rocks are mostly soft sandstones and clays, in some places false-bedded, everywhere particolored, usually horizontal, but at many places showing a landward dip. The upper part of these bluffs are probably Pliocene, but fossil fishes found in the lower shales at Riacho Doce and at other places on the immediate coast are Eocene. 
The remains of extinct Pleistocene vertebrate animals are frequently found in old marshes where excavations are made for watering places for cattle.

Economic geology.-Our present knowledge of the economic geology of the state is confined to the limestones found in the Archean area of the interior, the bituminous shales of the coast, and the structural features favoring the finding of water in the area of the coast sediments.

Crystalline limestone or marble is known at Ipueiras between Quebragulo and Palmeira dos Indios (Dombré 38), at or near Colonia Leopoldina (Galvão), and on the road between Sant'Anna and Aguas Bellas. It probably exists at many other places in the Archean area of the state. Most of the lime used in Alagoas is made from corals taken from the reefs along the coast.

Coal has been reported from the vicinity of Paulo Affonso, but its existence, either there or elsewhere in the state, is doubtful.

The bituminous shales are confined to the coastal belt of Tertiary sediments. These shales are known here and there along the coast from Bica da Pedra, just east of the city of Alagoas, to Rio Persinunga, at the Pernambuco frontier. It is quite probable that they continue southward nearly to the mouth of Rio São Francisco, but they have not yet been reported from that region. No attempt has been made to utilize these shales, though a report was made on them many years ago. (See Redwood and Topley and Branner.)

The area of Tertiary sediments is one in which water may reasonably be expected-possibly artesian water in some places.

Three-fourths of the state lies in the region of the Brazilian complexgranites, gneisses, and crystalline schists-in which many minerals of value are likely to be found.

\section{Geologic Map of Alagoas}

John C. Branner, 1910.-But one attempt has been made at a geological map of Alagoas; that is by J. C. Branner and was published in connection with an article, "The geology of the coast of the State of Alagoas, Brazil," which appeared in volume VII, number 1, of the Annals of the Carnegie Museum in 1910. The map forms plate II of that paper. It is on a scale of 1 to $1,238,095$; it shows only the eastern part of the State. Only four divisions of the geologic column are attempted: old crystalline, Paleozoic, Estancia, and Tertiary. The Estancia beds are there called Trias with a question. Later studies show the Estancia beds to be Permian-some of them at least. 


\section{Bibliography of the Geology of Alagoas}

Octavro Brandão: a mineralogia e a geologia dos canaes e das lagoas. Conferencia, etcetera. Maceio. (Outubro de 1917), paginas 38.

3. C. Branner: Cretaceous and Tertiary geology of the Sergipe-Alagoas basin of Brazil. Transactions of the American Philosophical Society, volume XVI, pages 369-434, plates i-iv, $4^{\circ}$. Philadelphia, 1889.

J. C. Branner : Two characteristic geologic sections on the northeast coast of Brazil. Proceedings of the Washington Academy of Science, volume II, pages 185-201. Washington, 1900.

J. C. Branner: The oil-bearing shales of the coast of Brazil. Transactions of the American Institute of Mining Engineers, volume XXX, pages 537-554. New York, 1901.

J. C. Branner : Geology of the northeast coast of Brazil. Bulletin of the Geological Society of America, vol. 8, pages 41-98. Rochester, 1902.

J. C. BraNner: The occurrence of fossil remains of mammals in the interior of the States of Pernambuco and Alagoas, Brazil. American Journal of Science, volume XIII, pages 133-137. New Haven, February, 1902.

J. C. Branner: The geology of the coast of the State of Alagôas, Brazil. Annals of the Carnegie Museum, volume VII, number 1, pages 5-22, illustrated. Pittsburgh, 1910.

F. L. C. Burlamaqui : Noticia de alguns mineraes, etc. Revista Brazileira, volume II, paginas 74-76. Rio de Janeiro, 1859.

Dr. Thomaz do Bom-Fim Espindola : Geographia Alagoana ou descripção physica, politica e historica da provincia das Alagôas. 2a edição. Maceío, Typ. do Liberal 1871. (Reino mineral, pages 91-92; mention of localities of limestones, marls, flint, and oil shales.)

Olympio Euzebio de ArRoxella Galvão: Succincta descripgrão do municipio de Porto Calvo (Provincia de Alagôas), 1881. Revista do Instituto Archeologico Alagoano, Junho de 1883, volume II, pagina 177.

Ch. Fred HartT: Geology and physical geography of Brazil. Maps and illustrations, xxiii +620 pages. Boston, 1870.

David S. Jordan : Description of a collection of fossil fishes from the bituminous shales at Riacho Doce, State of Alagôas, Brazil. Annals of the Carnegie Museum, volume VII, number 1, pages 23-34, illustrated. Pittsburgh, 1910.

Boverton Redwood and William Topley : Report on the Riacho-doce and Camarajibe shale deposits on the coast of Brazil near Macelo. $8^{\circ}, 12$ pages and maps. London, 1891.

\section{AMAZONAB}

Previous investigations.-The map of the State of Amazonas is chiefly from the sheets published by the Inspectoria Federal das Estradas, under Dr. José Estacio de Lima Brandão, in 1913. The streams in the southeastern part of the State, especiplly the Gy-Paraná, Theodoro, the Tapajos, and part of the Madeira, are from the map accompanying the lectures by Colonel Candido M. de Silva Rondon, published at Rio de Janeiro in 1916. 
Our knowledge of the geology of the State of Amazonas is of the fragmentary kind found in the notes of travelers along the Amazon, the Rio Negro, and the Madeira rivers and a few other of the large tributaries. Explorations in the region have been confined almost exclusively to trips made along the navigable streams, for there are very few roads in that State. The geology as shown along the extreme northern part of the map is taken from Brown and Sawkins' geological map of British Guiana and from the notes of Roderic Crandall, who lived for some time at Boa Vista, on Rio Branco.

A good résumé of the geology and physical features is given by Herbert $\mathrm{H}$. Smith as an appendix to his "Brazil, the Amazons and the Coast" (pages 619-635, New York, 1879). Bates' "The Naturalist on the Amazon". is a classic, though it does not contain much on the geology. Of the titles given below, the following relate to paleontology: Boettger, Brown, Clarke, Conrad, Ethridge, Gabb, Gervais, Gürich, and Woodward.

General geology.-There are two large areas of Archean rocks in the State of Amazonas, one on the north side, the other on the south side of the Amazon River. A great synclinal fold, beginning somewhere in the State of Pará, runs along the axis of the Amazon Valley at least as far as Manaus, and in this basin are sedimentary rocks of Silurian, Devonian, and Carboniferous age, all of them dipping gently toward the axis of the valley.

The Silurian rocks are marine sediments, mostly thin-bedded sandstones, the equivalent of the Niagara of North America. On the Rio Trombetas they are best exposed at the first and second falls, in zones from six to eight kilometers wide. They are estimated to have a thickness of about three hundred meters.

The Devonian rocks of the state are coarse white and yellow sandstones and black and reddish shales, all of them dipping southward at an angle of five degrees. They have a total thickness of about two hundred meters.

The Carboniferous beds are exposed on the Jamunda and Uatuma on the north side of the Amazon and on Rio Abacaxis on the south side. They are shales, sandstones, and limestones, the last named containing marine fossils. The total thickness of the Carboniferous beds is about six hundred meters.

In 1918 the federal government of Brazil had a well put down in the Carboniferous beds on the headwaters of Rio Maués between Tapajos and the Canumá. It passed through limestones, shales, and sandstones, and reached a depth of 292 meters. To a depth of 217 meters several of the limestone beds contained marine Carboniferous fossils.

These Paleozoic rocks, however, are known only in the eastern end of 
the State of Amazonas; they are not certainly known west of 58 degrees longitude on the south side of the valley or west of 60 degrees on the north side. Farther west the Paleozoic beds are concealed by the soft Tertiary and Quaternary deposits that cover thousands of square miles and extend westward to and beyond the Peruvian frontier. Here and there the Archean and Paleozoic beds are cut by dikes of eruptive rocks, but nowhere in the Amazonas region are the dikes known to pass through Cretaceous or Tertiary beds.

Of the area about the headwaters of the Rio Branco but little is known beyond what is to be had from the reports of Brown and Sawkins on the adjoining parts of British Guiana. The areas colored as questionable Cretaceous are merely areas of sandstone resting on the Archean. The rocks have as yet furnished no fossils.

Of the area between Rio Negro and the Amazon but little is known, further than that it is a flat, forest-covered region of sluggish streams. The country of the western end of the state is represented as Pliocene chiefly on account of the determinations of fossils by Ethridge. (See bibliography below.) The rocks are mostly incoherent sands and clays. The Miocene area, however, embraces large tracts that should properly be shown as alluvial deposits along the streams. Our knowledge of the limits of such areas is too fragmentary to allow them to be shown on the map.

Economic geology.-Gold is said to be found about the headwaters of some of the rivers of the State of Amazonas, but there is no systematic mining of any kind. Limestone is abundant in the Carboniferous rocks exposed along the rios Paranary and Amana and probably also on the Abacaxis. Similar deposits on the Jamundá and Uatuma probably contain limestones. Good clays for the manufacture of bricks, tiles, and the common ceramic ware used in the region are abundant; and the Archean region along the upper Rio Negro and Rio Branco furnishes unlimited supplies of excellent granite for building stones.

Lignite has long been known in the western part of the State of Amazonas. It occurs in the fresh-water Tertiary beds about Tabatinga on the upper Solimões, Javary, and Iça, and it probably has a wide, but uneven, distribution over an enormous area along the Peruvian frontier. Analyses show it to contain about 33 per cent of fixed carbon, about 39 per cent of volatile hydrocarbon, and 15 per cent of ash.

\section{Geologic Maps of Amazonas}

C. Barrington Brown, 1879.-The paper by C. Barrington Brown, "on the ancient river deposits of the Amazon," published in the Quarterly 
Journal of the Geological Society of London, volume 35, 1879, contains a small scale map (plate 38) showing the distribution of recent alluvium and the old river deposits of the region between the Brazilian and Peruvian frontier and the mouth of the Amazon, while the character of the rocks in the adjoining areas are given and the ages of some of them are stated.

H. Karsten, 1886.-The geological sketch accompanying Karsten's "Géologie de l'ancienne Colombie bolivarienne, Venezuela, NouvelleGranade et Ecuador, Berlin, 1886," represents the geology of the State of Amazonas west of Manaus. The map is on a scale of 1 to about 7,418,000 , and only two geologic divisions are shown in the Brazilian area, namely, plutonic and Tertiary and Quaternary-the last two in one color.

\section{Bibliography of the Geology of Amazonas}

I. Aqassiz: Lettre a M. Marcou sur la Géologie de la vallée de l'Amazone, avec des remarques de M. Jules Marcou. Bulletin de la Société Géologique de France, 2me série, XXIV, pages 109-111. Paris, 1866.

Lodis Agassiz: Physical history of the Amazon Valley. Atlantic Monthly, 1866, July and August, pages 49-60, 159-169. Boston, 1866.

Professor and Mrs. Louis Agassiz: A journey in Brazil: xix +540 pages, illustrated. Boston, 1868. (Chapter XIII, Physical history of the Amazons, pages 397-441, and many geological notes.)

R. H. Blake: Notes on the alto Rio Branco, North Amazonas. Geographical Journal, May, 1916, volume 47, pages 364-368.

Oskar Boettger: Die Tertiärfauna von Pebas am oberen Marañon. Jahrbuch der K. K. Geologische Reichsanstalt, 1878, XXVIII Band, 3 Heft, paginas 485-504.

Chardes B. Brown and J. G. Sawkins: Reports on the physical, descriptive, and economic geology of British Guiana. 297 pages, illustrated. London, 1875. Geology on the Brazilian frontier.

C. Barkington Brown and Wrulam Lidstone: Fifteen thousand miles on the Amazon and its tributaries. With maps and wood engravings. 520 pages, $8^{\circ}$. London, 1878.

C. Barkington Brown: On the Tertiary deposits on the Solimones and Javary rivers in Brazil. With an appendix by R. Etheridge. Quarterly Journal of the Geological Society, volume XXXV, pages 76-88. London, 1879.

C. Barrington Brown: On the ancient river deposit of the Amazon. Quarterly Journal of the Geological Society, volume XXXV, pages 663-777. London, 1879.

W. Chanduess : Notes on the River Aquiry, the principal affuent of the River Purus. Journal of the Royal Geographical Society, volume XXXVI, pages . 119-128, map. London, 1866. Abstract in Proceedings of the Royal Geographical Society, volume XI, 1866-7, pages 100-102.

W. Chandess : Apontamento sobre o Rio Aquiry, afluente do Rio Purus. Annexo (letra $n$ ) ao Relatorio do Ministro de Agricultura, etc., 1-6 paginas. Rio de Janeiro, 1866. 
W. Chandiess : Notes of a journey up the River Jurua. Journal of the Royal Geographical Society, volume XXXIX, pages 296-311. London, 1869.

W. Chandess : Notes on the rivers Maué-assí, Abacaxis, and Canuma, Amazons. Journal of the Royal Geographical Society, volume XL, pages 419 . 432. London, 1870.

W. Chandess : Exploração dos rios Jurua, Maué-assú e Abacaxis. Annexo (letra $\mathrm{n}$ ) ao Relatorio do Ministro de Agricultura, etc., paginas 1-16. Rio de Janeiro, 1870.

Grorge E. Church : The route to Bolivia via the River Amazon. $8^{\circ}, 216$ pages. London, 1877.

T. A. Conrad : Descriptions of new fossil shells of the upper Amazon. American Journal of Conchology, volume VI, pages 192-198. Philadelphia, 1871.

T. A. Conrad: Remarks on the Tertiary clay of the upper Amazon, with descriptions of new shells. Proceedings of the Philadelphia Academy of Sciences, volume XXVI, pages 25-32. Philadelphia, 1874.

J. M. DA Sinva Coutinho: Relatorio apresentado ao Presidente da Provincia do Amazonas, por J. M. da Silva Coutinho, encarregado de examinar o Rio Madeira. Annexo (letra G) ao Relatorio do Ministro da Agricultura, etc., 21 paginas. Rio de Janeiro, 1862.

J. M. DA Silva Coutinho: Relatorio da Exploração do Rio Purus. Annexo ao Relatorio do Ministro de Agricultura, etc., 96 paginas. Rio de Janeiro, 1862.

J. M. Da Silva Cootinho : Exploraç̃o do Rio Madeira. Annexo (letra 0) ao Relatorio do Ministro de Agricultura, etc., paginas 55-63. Rio de Janeiro, 1866.

R. Etheridge: Notes on the Mollusca collected by C. Barrington Brown from the Tertiary deposits of Solimões and Javary rivers, Brazil. (Appendix to Brown's paper.) Quarterly Journal of the Geological Society, volume XXXV, pages 82-88, one plate. London, 1879.

J. W. Evans: The rocks of the . . . Madeira. Quarterly Journal of the Geological Society, volume LXII, pages 88-124. London, 1906.

W. M. GABB: Descriptions of fossils from the clay deposits of the upper Amazon. American Journal of Conchology, volume IV, pages 197-207. Philadelphia, 1898.

PaUl Gervars: Crocodile Gigantesque fossils au Brésil. Journal de Zoologie, Tome V, pages 232-236. Paris (1876).

G. GünICH : Gryposuchus Jessei . . . Jahrbuch der Hamburgischen Wissenschaften Anstalten, volume XXIX, pages 59-71. Hamburg, 1912.

Dr. Hermann Karsten: Geologie de l'ancienne Colombie, Bolivarienne, Vénézuela, Nouvelle-Grenade et Ecuador. Berlin, 1886. $\quad\left(4^{\circ}\right.$, arec 8 planches et une carte geologique.) The geological map colors geologically the Amazonas region west of Manaos.)

Frasyz Keture : The Amazon and Madeira rivers. Sketches and descriptions from the note-book of an explorer. By Franz Keller. $4^{\circ}$, xvi +177 pages. New York, 1874. Notes on the geology.

Fuzerio Paulo de Outverra : Expediça Scientifica Roosevelt-Rondon. Annexo I, Geologia. Rio de Janeiro, 1915.

James Orton: Physical observations on the Andes and the Amazons. American Journal of Science, volume XCVI, pages 203-213. New Haven, 1868. 
James Orton: On the valley of the Amazon. Proceedings of the American Association for the Advancement of Science, 1869, volume XVIII, pages 195-199. Cambridge, 1870.

JAMEs OrTON : On the evidence of a glacial epoch at the equator. Proceedings of the American Association for the Advancement of Science; volume XIX, pages 185-193. Cambridge, 1871. Annals and Magazine of Natural History, volume VIII, pages 297-305. London, 1871.

JAMEs ORToN: The Andes and the Amazon, or across the continent of South America. Third edition, $645+$ xxiii pages. New York, 1876.

J $\triangle$ MES ORTON : (Quotations upon the drift of the Amazon Valley.) Annual of Scientific Discovery for 1871, pages 245-246. Boston, 1871.

Eusté Recuus: Nouvelle Géographie universelle. La terre et les Hommes. Volume XIX, Amérique du Sud, l'Amazonie et la Plata. Paris, 1894. Brésil, pages 91-495.

H. Rrce: Uaupés (Brazil) Geographical Journal, volume XXXV, pages 682700. London, 1910.

JoÃo Barbosa Rodrigues : Explorağo dos rios Urubú e Jatapa. Relatorio, etc. Rio de Janeiro, 1875. (Includes also Rio Uatuma.)

R. H. Sohomburgk : Report of the third expedition into the interior of Guyana, etc. Journal of the Royal Geographical Society, volume X, pages 159-190. London, 1841.

R. H. Schomburgk : Journey from Fort San Joaquim, on the Rio Branco, to Roraima, and thence by the rivers Parima and Merewari to Esmeralda, on the Orinoco, in 1838-9. Journal of the Royal Geographical Society of London, volume $X$, pages 191-247. London, 1841.

R. H. Schomburgk: Journey from Esmeralda, on the Orinoco, to San Carlos and Moura, on the Rio Negro, and thence by Fort San Joaquim to Demerara, in the spring of 1839 . Journal of the Royal Geographical Society of London, volume $\mathrm{X}$, pages 248-267. London, 1841.

Herberat H. SMITH : Geology and physical geography of the Amazons Valley. Appendix to "Brazil, the Amazons and the coast," pages 619-635. New York, 1879.

SpIx und Martius: Reise in Bresilien auf Befehl Sr. Majestät Maximilian Joseph I. Königs von Baiern in den Jahren 1817 bis 1820 gemacht und beschrieben von Dr. John Bapt. von Spix . . . und Dr. Carl Friedr. Phil von Martius. Volume III, pages 1054-1376. München, 1831. $4^{\circ}$.

Rrchard Spruce: Notes of a botanist on the Amazon and Andes. Edited by Alfred R. Wallace. Two volumes, $8^{\circ}$, illustrated. London, 1908. (Notes on the rocks of the upper Rio Negro and its tributaries.)

RICHard Spruce: On the River Purus. Report of the British Association for the Advancement of Science, 1864; Transactions; page 148. London, 1865.

ALFRED R. WALLACE: On the Rio Negro. Journal of the Royal Geographical Society (map), volume XXIII, pages 212-217. London, 1853.

ALFred R. Wallace: A narrative of travels on the Amazon and Rio Negro. $8^{\circ}$. London, 1870.

Henky Woodwand: The Tertiary shells of the Amazon Valley: Annals and Magazine of Natural History, 4th series, volume VII, pages 59-64, 101-109. London, 1871. 
$B A H I A$

Previous investigations.-The base map of the State of Bahia has been prepared partly from the original map of Branner, Crandall, and Williams, partly from the maps of Dr. Theodoro Sampaio, and partly from those of the Inspectoria de Obras Contra as Seccas made under the direction of Dr. M. A. R. Lisboa.

The geology of Bahia as given on the map has been prepared chiefly from the author's own observations and notes, supplemented by the notes of his assistants, Roderic Crandall and Horace E. Williams. The notes on the geology made by Dr. Theodoro Sampaio on a trip from Carandahy to Bahia form a valuable contribution to our knowledge, while the notes of Sir Richard Burton and of Halfeld on the geology along the Rio São Francisco, though fragmentary, have been very helpful. The region north of Rio São Francisco was crossed by George Gardner and by J. W. Wells, who give useful notes on the geology.

The coast region is described by Rathbun on Itaparica, by Gonzaga de Campos on Marahú, by Branner on the whole coast, while the fossils are described by Jones, Krasser, C. A. White, and A. Smith Woodward.

The great Bemdigo meteorite found in the interior of Bahia and removed to Rio de Janeiro in 1888 is described by Carvalho, Daubré, and Derby.

General geology.-The geology of the State of Bahia is remarkably varied and interesting. The rocks of the Brazilian complex-the Archean

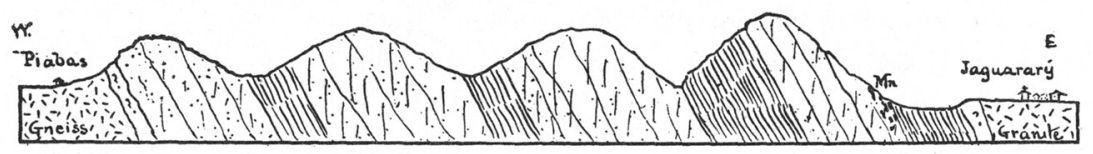

FIGURE 5.-Section 10 Kilometers long across the Serra de Jacobina at Jaguarary, State of Bahia

The old Paleozoic beds are faulted, and thrust beneath the Archean on the east. The location of the manganese beds is near east base of the mountains.

granites, gneisses, and schists-are exposed over large areas; into these oldest rocks have been faulted and folded here and there an old series of quartzites and other metamorphosed rocks that appear in the topography as isolated peaks and ridges, usually with their beds standing on end or at high angles. These rocks are shown on the map as early Paleozoic, and are typified in Bahia by the Serra de Jacobina, Serra de Angico, and by the long isolated ridges of quartzite west of Rio São Francisco between Barra and Urubú. No paleontologic evidence of the age of these beds has yet been found.

Extending along the east side of the Rio São Francisco from near 



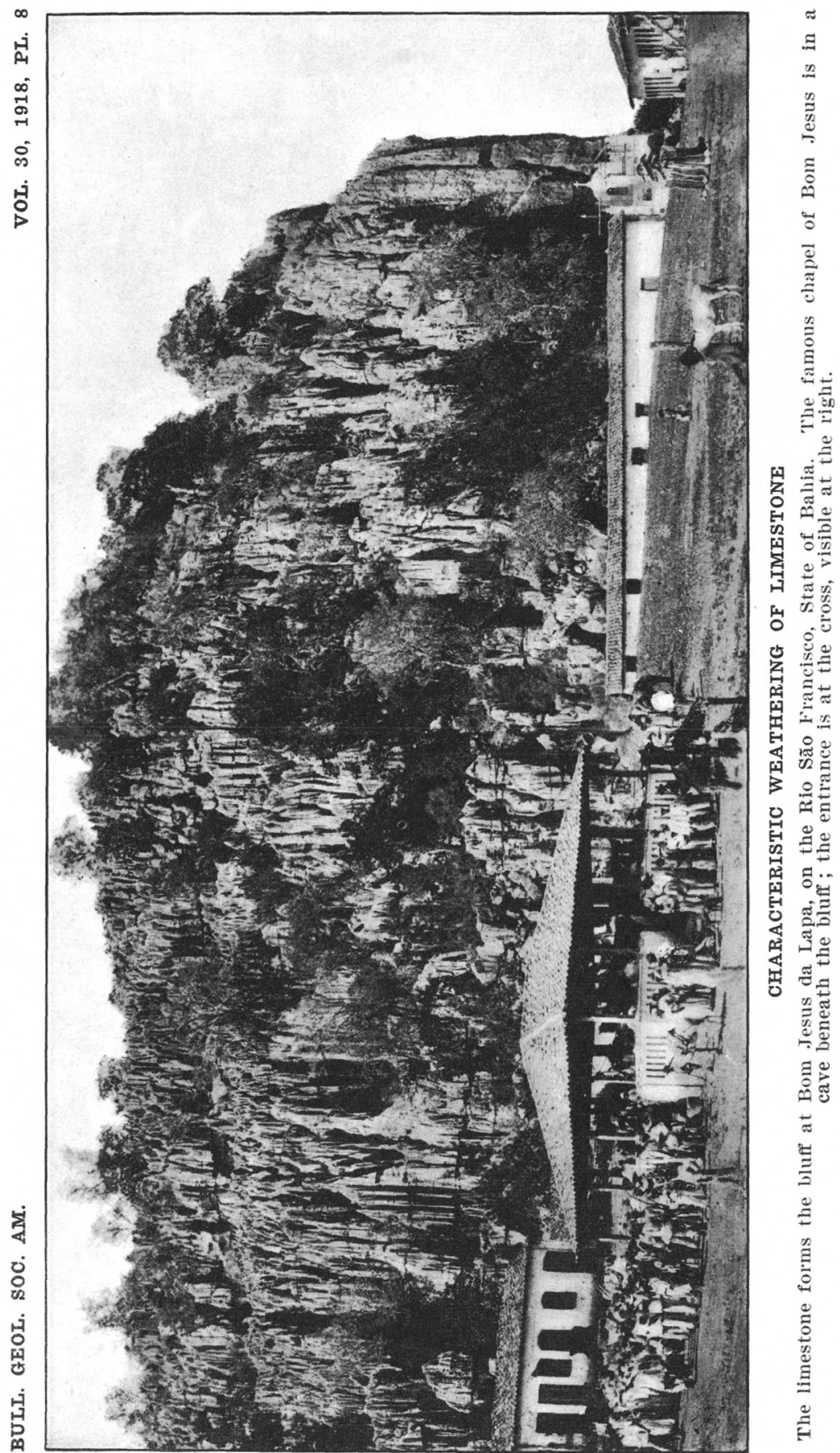


Joazeiro to the southern end of the State of Bahia, and extending into Minas beyond, is a mountainous and hilly region averaging 200 kilometers in width, mostly of Paleozoic sediments folded, faulted, and denuded. They are made up chiefly of hard quartzitic sandstones, shales, and slates covered here and there by limestones. The geologic ages of

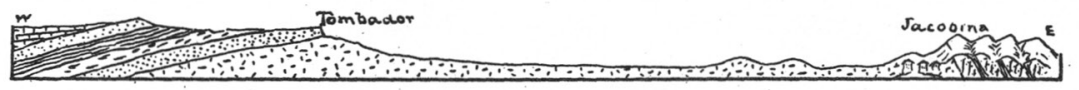

FigURE 6.-East-west Section across the Serra do Tombador, the Serra de Jacobina, and the Archean Valley between

these rocks are not certainly known; for, with the exception of certain limestones to be mentioned later, not one of them has yet yielded recognizable fossils.

The lowest rocks of this group, the Tombador beds, have been referred tentatively to the Silurian. These lowest of the sedimentary rocks form the escarpment of the Tombador range west of Jacobina, the cap rock of

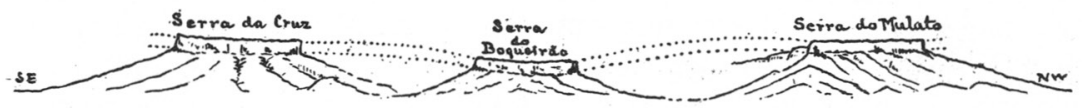

FIgURE 7.-Structural Relations of Serra da Cruz, Serra do Boqueirão, and Serra do Mulato

The crests are of Tombador quartzite; the slopes and plains are of old crystalline rocks.

the Serra do Mulato, Serra da Cruz, Serra do Encaibro, Serra de Macaubas, and Serra Geral on Rio São Francisco, and they generally underlie the later rocks of the diamond mining regions of the State of Bahia.

The limestones at.Bom. Jesus da Lapa on Rio São Francisco have been referred by Derby to the Silurian on the evidence of the fossils Favosites

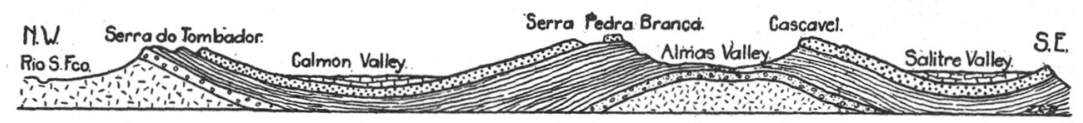

FIGURE 8.-Northwest-southeast Section from Rio são Francisco to the Salitre Valley, about 160 Kilometers

The section shows the general geologic structure of the diamond region of Bahia. The Caboclo shales are exposed in the Almas Valley, with the diamond-bearing beds overlying them.

and Chetetes found there. This determination, however, is not to be regarded as final, for both of these fossils occur also in the Devonian, and the Chetetes is even found in the Carboniferous.

Next above the Tombador beds is a series of slaty shales well exposed. in the Almas Valley, and called the "Caboclo shales" for the Caboclo peak 
on the east side of the Almas Valley. These shales have been referred to the Devonian, but without paleontologic evidence.

Resting on the Caboclo shales are the Lavras quartzites and sandstones from which the diamonds and carbonados are obtained in the State of Bahia. These quartzites and sandstones are sometimes yellowish brown, white, or gray, but they are more frequently pinkish and are almost everywhere strongly false-bedded. Over most of the area they are folded, and in some places they are much faulted. They are represented on the map as doubtful Carboniferous, for here again no paleontologic evidence has yet been found of their age.

The Lavras beds have a total thickness of two hundred to two hundred and fifty meters near Lençoes. (Crandall.)

I am of the opinion that the Lavras quartzites of Bahia are to be correlated with the diamond-bearing quartzites of Grão Mogol, in the State of Minas Geraes. Unfortunately the structural connection between the two regions has never been worked out. See also page 265 .

Overlying the diamond-bearing quartzites of the Chapada diamantina is a series of limestones with interbedded shales that I have hitherto referred with doubt to the Jurassic and Triassic. ${ }^{46}$ The accumulated evidence leads me to conclude that the limestones called by me the Salitre are simply the northward extension of the Lower Permian limestones of the Rio das Velhas, Rio Verde, and of the upper Rio São Francisco.

The maximum thickness of these limestones in Bahia is not known, but it is at least 100 meters. They are mostly horizontal and thin bedded, but in some places they are highly folded. It is not at all improbable that there are limestones in the Chapada diamantina older than the Permian, but data for distinguishing them are entirely lacking at present.

At Jacú, a few kilometers east of the town of Aracy, which is 40 kilometers north of Serrinha, a station on the Bahia São Francisco Railway, fossils of Permian age have been found in dark gray shales. Permian

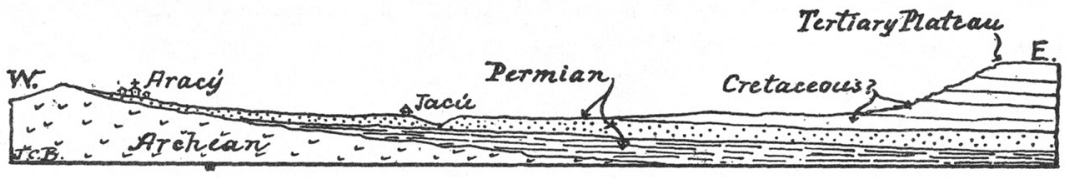

FIGURE 9.-Section from the Archean near Aracy to the Tertiary Table-lands to the East

fossils have also been found 12 kilometers south of the town of Bom Conselho, in eastern Bahia. The Permian beds at these two places underlie the tablelands that form the belt shown on the map as Cretaceous and

${ }^{46}$ Am. Jour. Sci., vol. xxxi, p. 481. Bul. Geol. Soc. Amer., vol. 22, p. 188. 
Tertiary and which extends from the vicinity of the city of Bahia to and across the Rio São Francisco above the falls of Paulo Affonso. The Permian rocks have not been recognized as such elsewhere throughout this entire zone, but it is assumed that they are continuous, and they are so represented on the map. Nowhere else in Bahia have the Permian rocks been certainly recognized.

In the Salitre Valley and over wide areas in the eountry north of Lavras the map shows limestones which are referred doubtfully to the Permian. These limestones have yielded no fossils, with the possible exception of some algæ that have thus far. baffled all attempts at determination. The age of the beds is therefore in doubt. In some places they seem to rest unconformably against the diamond-bearing quartzites referred to the Carboniferous. It is not at all clear, however, that these limestones are all of the same geologic age.

Cretaceous rocks are exposed at many places about the Bay of Bahia, on the east side of the island of Itaparica, at Marahú, and at many places through the zone of sedimentary rocks that extends from Bahia northward to near Jatobá, on the Rio São Francisco. At Marahú and about the Bay of Todos os Santos fossils have been found, and there is no question about the age of certain rocks. All of the sedimentary rocks thereabout are not Cretaceous, however, as seems to be inferred occasionally, for there are at many places remnants of the Tertiary beds, most of which have been completely removed by denudation. On the island of Itaparica Dr. Rathbun recognized Tertiary beds on the west side of the island; at Monserrate, in the suburbs of Bahia, brackish water fossils are found that are certainly Tertiary, ${ }^{47}$ and in some of the railway cuts northwest of Alagoinhas Tertiary plant remains are abundant in sediments overlying unconformably the Cretaceous beds ${ }^{48}$ at kilometer $28+$.

Any one who undertakes geologic or paleontologic work in the vicinity of the Bay of Bahia should not fail to read the paper by Joseph Mawson published in the Geological Magazine of August, 1913, pages 356-361. Mr. Mawson lived at Bahia many years, and it is to him that we owe the valuable collections of Cretaceous vertebrate remains described by Dr. A. Smith Woodward.

Along the coast, both north and south of Bahia, is a narrow belt of Tertiary sediments that lap back over the older formations. This belt is cut through here and there by the drainage, and where the sea has undercut the beds they form the particolored cliffs that characterize this part

\footnotetext{
47 See Chas. A. White's Contributlons to the Paleontology of Brazll. Archlvos do Museu Nacional, vil, p. 233.

${ }^{49}$ F. Krasser : $K$. von. Ettingshausen's Studien uber die fossile flora von Ouricanga in Brasilien. Sitz. der K. Akad. d. Wiss. Wien., cxif, 1903.
} 
of the Brazilian coast. The Tertiary beds are mostly horizontal sands and clays.

In some parts of the interior of Bahia ant-hills of enormous size cover the surface of the ground so completely that they seriously interfere with its cultivation and produce a peculiar and striking minor topography.

Economic geology.-The minerals and rocks of economic importance in the State of Bahia are gold, diamonds, carbonados, amethysts, monazite sands, manganese, bituminous shales, marbles, limestones, and pottery clays. These materials have all been worked in Bahia except possibly

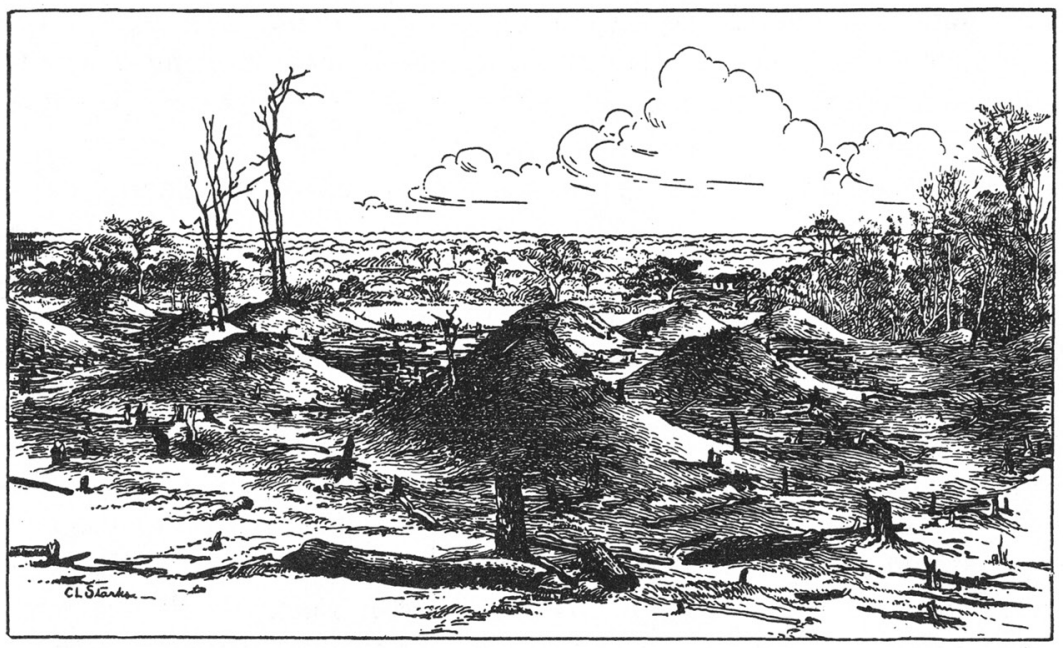

Figure 10.-Ant-hills on Rio Utinga

The view is taken near the village of Pegas, State of Bahia. From a photograph by R. Crandall, 1907.

the marbles. Bituminous shales were worked at Marahú for a while, but the enterprise was soon abandoned. There are, however, other mineral resources in the state that have not yet been developed; such are iron, considerable bodies of which occur below Chique-Chique; copper, found at Carahyba; mica, talc, graphite, grindstones, whetstones. Nitrate of potash and salt are found in the interior of the state, but the nitrate occurs only as cave deposits, while the salt is manufactured by leaching the surface earth from dry lake beds, mostly in or near the limestone areas. The limestones and clays so abundant in the state might be used for the manufacture of Portland cement, but they have never been utilized.

Those who seek information in regard to the geology of the diamond 
and carbonado regions should consult the papers of Branner, Derby, Crandall, Furniss, Gorceix, and Oliveira.

The monazite sands are described in a résumé by Dr. Calogeras in his "Minas do Brasil e sua legislação," pages 447-47\%. Other writers on monazite sands are Derby, Gorceix, Praguer, and Britto. The manganese deposits are spoken of by Branner and are mentioned under "Monazite" above.

\section{Geologic Maps of Bahia}

Pissis, 1842.--In his Mémoire sur la position géologique des terrains de la partie australe du Brésil, par M. A. Pissis, published by the Academy of Sciences at Paris in 1842, the accompanying geologic map includes the geology of the southern part of the State of Bahia. Four divisions of the "terrain primitif" are shown. The map shows evidences of some work at and south of the Bay of Bahia.

Branner, Crandall, and Williams, 1908.-A map showing the geology of that part of the State of Bahia lying south of Rio São Francisco, east of west longitude $43^{\circ}$ and north of latitude $12^{\circ} 30^{\prime}$ was published by the Inspectoria de Obras Contra as Seccas in 1908, under the title "Mappa de parte dos estados da Bahia, Pernambuca e Piauhy e dos estados de Sergipe e Alagoas por J. C. Branner, R. Crandall, e H. E. Williams." It was originally prepared for the Serviço Geologico e Mineralogico do Brasil, but it was only issued as stated above. It is on a scale of 1 to 2,000,000 and shows six geologic subdivisions: crystallines, Jacobina series, Tombador series, Lavras series, Salitre series, and recent Tertiary and Cretaceous-the last three in one color. This map is not accompanied by any text.

Branner, 1909.-A short article by Branner on "the diamond-bearing highlands of Bahia," published in the Engineering and Mining Journal, New York, May 15 and 22, 1909, was accompanied by a geological sketchmap of the region between the city of Bahia and Chique-Chique, on the Rio São Francișco. The scale was 1 to 3,030,303 and four geologic divisions were shown, namely: crystalline, Lavras, Salitre limestone, Cretaceous and Tertiary-the last two as one. The geology on that map was based almost exclusively on observations made by the author and his assistants.

Soper, 1914.-In 1914 the eastern part of the State of Bahia was shown on a map accompanying the report of $R$. H. Soper to the Inspectoria de Obras Contra as Seccas. This was publication number 34 of the Inspectoria, and has the title "Geologia e supprimento d'agua subterrenea em Sergipe e no nordeste da Bahia." The map is on a scale of 1 
to $1,000,000$ and four subdivisions of the geology are shown, namely: pre-Cambrian, Paleozoic, Permian (?), Cretaceous, and Tertiary-the last two combined.

\section{Bibliography of the Geology of Bahia}

J. A. ALLEN : Notes on the geological character of the country between ChiqueChique, on the Rio de São Francisco, and Bahia, Brazil. Hartt's Geology and Physical Geography of Brazil, pages 309-318. Boston, 1870.

S. AlxpoRT: On the discovery of some fossil remains near Bahia, in South America. Quarterly Journal of the Geological Society, volume XVI, December, 1850, pages 263-266. London, 1860.

E. DE Bennet : Contribution à la Flore pliocène de la province de Bahia. Bulletin Museúm Histoire Naturelle, pages 510-512. Paris, 1905.

J. C. Branner: The manganese deposits of Bahia and Minas, Brazil. Transactions of the American Institute of Mining Engineers, volume XXIX, 1899, pages 756-770. New York, 1900.

J. C. Branner: The oil-bearing shales of the coast of Brazil. Transactions of the American Institute of Mining Engineers, volume XXX, pages 537-554. $8^{\circ}$, illustrated. New York, 1901.

J. C. BranNer: The diamond-bearing highlands of Bahia. I, Engineering and Mining Journal, volume LXXXVII, pages 981-986, New York, May 15, 1909 ; II, volume LXXXVII, pages 1029-1032, New York, May 22, 1909.

J. C. Branner: Geology of the Serra do Mulato, State of Bahia, Brazil. American Journal of Science, 4th series, volume XXX, October, 1910. pages 256-263.

J. C. Branner: The Tombador escarpment, in the State of Bahia, Brazil. American Journal of Science, 4th series, volume XXX, November, 1910, pages 335-343.

J. C. Branner: Minerals associated with dlamonds and carbonados in the State of Bahia, Brazil. American Journal of Science, volume CLXXXI, June, 1911, pages 480-490.

J. C. Branner: The aggraded limestone plains of the interior of Bahia and the climatic changes suggested by them. Bulletin of the Geological Society of America, volume 21, pages 187-206, illustrated. New York, June, 1911.

J. C. Branner: The geography of northeastern Bahia. Geographical Journal, volume XXXVIII, August, 1911, pages 139-152, 256-269. London, September, 1911.

J. C. Bran Ner: The Estancia beds of Bahia, Sergipe, and Alagoas, Brazil. American Journal of Science, 4th series, volume XXXV, June, 1913, pages 619-632.

J. C. Branner: Geologic work of ants in tropical America. Bulletin of the Geological Society of America, volume XXI, August, 1910, pages 449-496.

David N. Burke: The Turfa mines in Brazil. U. S. Consular Reports, volume XXX, pages 353-355. Washington, 1889.

Captain RICHARD F. BuRToN : Explorations of the highlands of the (sic) Brazil. Two volumes, $8^{\circ}$. London, 1869.

Antonio Alves Camara: O manganez no Estado da Bahia. Revista do Instituto Polytechnico Brazileiro, 1906, and separate, 28 pages. 
I. F. Gonzaga DE Campos: Reconhecimento geologico de substancias bituminosas na bacia do Rio Marahú, Estado da Bahia. 21 pages, $4^{\circ}$, with geological map. São Paulo, November, 1902.

Francis de Castelnau: Sur l'exploitation du diamant dans la province de Bahia, Brèsil. Annales des Mines, 5me série, volume II, page 594. Paris, 1852.

Nicolas Chatrian : Sur le gisement de diamants de Salobro, Brésil. Bulletin Société Française de Minéralogie, volume IX, pages 302-305. Paris, 1886.

Roperic Crandall: Notes on the geology of the diamond region of Bahia, Brazil. Economic Geology, May, 1919, volume XIV, pages 220-244.

W. J. DAkIN : The Abrolhos Islands. Nature, December 10, 1904, volume 94, page 406.

c. A. Derby : A bacia cretacea da Bahia de Todos os Santos. Archivos do Museu Nacional, volume III, paginas 135-158. Rio de Janeiro, 1878.

o. A. Derby : Reconhecimento geologico do Valle de São Francisco. 24 pages, $4^{\circ}$. Annexo ao Relatorio de W. Milnor Roberts. Rio de Janeiro, 1880. Tambem na Revista de Engenharia, volume III, paginas 93-94, 125-127, 139-143, 172-175, 188-190. Rio de Janeiro, 1881.

O. A. Derby : Geology of the Rio São Francisco, Brazil. American Journal of Science, third series, 1880, volume XIX, page 236.

o. A. Derby : Notas geologicas sobre o Estado da Bahia, Boletim da Secretaria da Agricultura, etc., do Estado da Bahia, volume VII, paginas 12-31. Bahia, 1905.

O. A. Derby : Lavras diamantinas. Relatorio apresentado ao Dr. Secretario da Agricultura da Bahia. Revista Inst. Geogr. e His. da Bahia, volume XI, paginas 143-153. Bahia, 1905.

o. A. Derby : Manganese deposits of Nazareth, Bahia. Abstract: So headed in Engineering and Mining Journal, volume LXXX, October 14, 1905, page 697. This refers to the March Bulletin of the Department of Agriculture of the State of Bahia.

Robert Frazer, Jr. (U. S. Consul at Bahia) : Manganese ores in Bahia. Engineering and Mining Journal, November 21, 1914, page 904.

H. Gorceix : Etude des mineraux qui accompagnent le diamant dans le gisement de Salobro, province de Bahia (Brésil). Bulletin Société Minéralogie de France, volume VII, pages 209-218. Paris, 1884. Annaes da Escola de Minas de Ouro Preto, n. 3, 1884, pages 219-230.

H. GorceIX: Sur des sables a monazites de Caravellas, province de Bahia Brésil. Comptes Rendus de l'Academie Science, O, pages 356-358. Paris, 1885. Bulletin Société Minéralogie de France, volume VIII, pages 32-35. Paris, 1885.

H. G. F. HALferd : Atlas e relatorio concernente á exploração do Rio de São Francisco desde a Cachoeira da Pirapora até o Oceano Atlantico, 18521854. Illustrated, 57 paginas, folio, 36 maps. Rio de Janeiro. 1860.

Ch. Fred. HaRtT: The cruise of the Abrolhos. American Naturalist, April, 1868, volume II, pages 85-93. Salem, 1869.

Ch. Fred. Harte: Geology and physical geography of Brazil. xxiil +620 pages. Boston, 1870.

T. RUPERT Jones: On the discovery of some fossil remains near Bahia, in South America. By $\mathbf{S}$. Allport. Note on the fossil Entomostraca from 
Montserrate, Bahia. Quarterly Journal of the Geological Society, volume XVI, pages 266-268. London, 1860.

T. RUPERT Jones : On some fossil Entomostraca from Brazil. Geological Magazine, New Series (4), May, 1897, volume IV, pages 195-202; also, July, 1897, volume IV, pages 289-293. London, 1897.

F. Krasser : Konstantin von Ettingshausen's Studien uber die fossile Flora von Ouriçanga in Brasilien. Sitzungsberichte der kaiserlichen Akademie der Wissenschaften, volume CXII, pages 852-860. Wlen, 1903.

Augusto Frederico de lacerda: The gold mines of Rio de Contas, in Bahia. Brazilian Mining Review, volume I, pages 250-251. Rio de Janeiro, July, 1904.

Dr. von Martius: Uber die neuerliche in der Serra de Sincurá im Sertão der Provinz Bahia ausgefundenen Diamanten-Lokalitäten. Gelehrte Anzeigen : Bulletin der $\mathrm{k}$. bayer. Academie der Wissenschaften, part II, number 197, pages 545-547. München, 1846.

Excerpts from von Martius' notes on Bahia have been translated into Portuguese by Dr. Pirajá da Silva and published under the title "Atravéz da Bahia." Bahia, 1916.

Joseph Mawson: Notes on the Cretaceous formation of Bahia, Brazil. Geological Magazine, August, 1913, pages 356-361. Map. London, 1913.

Joseph Mawson: Lapa do Brejo Grande na Provincia da Bahia. Revista da Sociedade de Geographia, do Rio de Janeiro, 1886, volume II, paginas 102103.

Josepr Mawson and A. Smith Woodward: On the Cretaceous formation of Bahia (Brazil) and on the vertebrate fossils contained therein. Geological Magazine, number 512, pages 93-94. London, February, 1907. Quarterly Journal of the Geological Society, volume LXII, pages 128-139. London, May, 1907.

Prinz zu Wied-Neuwied Maximmian: Reise nach Brasilien, 1815-17. 2 Bde. Mit 3 Krtn., 22 Taf. Atlas Fol. Kart. Frankfurt, 1820-1821. Also in French. Paris, 1821-1822.

JoHN Morris : On the discovery of some fossil remains near Bahia, in South America, by S. Allport. Note on the molluscan remains from Monserrate. Quarterly Journal of the Geological Society, volume XVI, page 266. Iondon, 1860.

Francisco de Paula Oliveira: The diamond deposits of Salobro, Brazil. Engineering and Mining Journal, November 16, 1901, volume LXXII, pages 635-636. New York, 1901.

Congalo de A. Pereira : Minas diamantiferas do Salobro. Boletim da Secretaria da Agricultura da Bahia, volume VIII, paginas 11-20. Bahia, 1906.

J. M. S. F. Pontes: Das Berggesetz von Bahia. Organ d. V. d. Bohrtechniker, pages 3-7. Wien, 1910."

Hentique Praguer: Riqueza mineral do Estado da Bahia, I, II, III. Formação geologica do Estado da Bahia, mineraes existentes, explorações antigas e modernas. Revista Trimensal do Instituto Geographico e Historico da Bahia. Anno IV, volume IV, No. 131, Setembro, 1897, paginas 419-431, Bahia, 1897. IV, Formação geologica da cidade da Bahia e seus arredores. V, Iha de Itaparica. VI, Terrenos de Massape de Santo Amaro. VII, De Alagoinhas para o Rio São Francisco. Anno V, volume,V, No. 15, Março de 
1898, paginas 81-106, Bahia, 1898. VIII, O diamante, paginas 57-68, Anno VI, volume VI, No. 19, Março de 1899, Bahia, 1899. Partes LII e LIII foram publicadas tambem na Revista Industrial de Minas Geraes, Anno V, No. 32, 30 de Novembro de 1897, paginas 97 (bis)-100. Ouro Preto, 1897. ANDRE PRZEWodowskI: Duas palavras sobre os terrenos entre a cidade da Bahia e o Joazeiro, considerados geologicamente, dated 18 de Março de 1848. Revista do Instituto Historico, volume $X$ (2a edição), paginas 384386. Rio de Janeiro, 1870 (for 1848).

Richard Rathrun: Observações sobre a geologia. Aspecto da Ilha de Itaparica na Bahia de Todos os Santos. Archivos do Museu Nacional, volume III, paginas 159-183. Rio de Janeiro, 1878.

Richard RATHBUN : Brazilian corals and coral reefs. American Naturalist, September, 1879, volume XIII, pages 539-551, illustrated. Philadelphia, 1879.

RICHARD RATHBUN : Notes on the coral reefs of the Island of Itaparica, Bahia, and of Parahyba do Norte. American Journal of Science, yolume CXVII, pages 326-327. New Haven, 1879. Proceedings of the Boston Society of Natural History, May, 1878, volume XX, pages 39-41. Boston, 1881.

J. W. Richardson: The Espirito Santo and Bahia monazite beds. Brazilian Mining Review, volume I, pages 79-84, illustrated. Rio de Janeiro, July, 1903.

Theodoro Fernandes Sampaio: (Relatorio sobre o reconbecimento da região entre Carinhanha e a Bahia.) Annexo 2 do Relatorio da Commissão $\mathbf{H y -}$ draulica sobre o Rio São Francisco, 8 paginas, $4^{\circ}$. Rio de Janeiro, 1880.

Theodoro Fernandes Sampaio: Informações a respeito dos caracteres geologicos do terreno comprehendido entre a cidade de Alagoinhas e a do Joazeiro pelo trajecto da linha ferrea em construcção. Revista de Engenharia, Marco 14, 1884, volume IV, paginas 52-54. Rio de Janeiro, 1884.

Theodoro Fernandes Sampaio: Carta do Reconcavo da Bahia gravada mediante auxilio do Governo do Estado na administração do Exmo. Sr. Cons. Luiz Vianna, Escala 1 to 250,000. Bahia, 1899. Notas sobre a geologia.

Theodoro Sampaio: O Rio de São Francisco e a Chapada Diamantina. São Paulo, 1906.

Patul Siedel : Beiträge zur Kenntniss erniger Mineralien aus villa do Bom Jesus dos Meiras, Brasilien. Neues Jahrbuch für Mineralogie, Beitrage Band XXXVIII, pages 759-804. Stuttgart, February, 1915.

RALPH H. SoPER: Geologia e supprimento d'agua subterranea em Sergipe e no norte da Bahia. Publicação n. 34 da Inspectoria de Obras contra as Seccas. Rio de Janeiro, July, 1914. Royal $8^{\circ}$, illustrated, geological map, 75 paginas.

SpIx und Martius: Reise in Bresilien auf Befehl Sr. Majestät Maximilian Joseph I, Königs von Baiern in den Jahren 1817 bis 1820 gemacht und beschrieben von Dr. John Bapt. von Spix . . . und Dr. Carl Friedr. Phil. von Martius. $4^{\circ}$, volume II, pages 594-753. München, 1828.

J. UhuIG: Monazit von Bom Jesus dos Meiras, Provinz Bahia Brasilien. Centralblatt für Mineralogie Geologische und Paleontologie, 1915, number 2, 15 Janeiro, pages 38-44. Stuttgart, January, 1915.

HenRY S. Washingron: An occurrence of pyroxenite and hornblendite in Bahia, Brazil. American Journal of Science, July, 1914, volume XXXVIII, pages 79-90. 
JAMES W. WeLLS: Exploring and traveling three thousand miles through Brazil, from Rio de Janeiro to Maranhão. In two volumes. London, 1866.

James W. Weuls: Notes of a journey from the River St. Francisco to the River Tocantins and to the city of Maranhão. Journal of the Royal Geographical Society, volume XLVI, pages 308-328. London, 1876.

David WHite: A new fossil plant from the State of Bahia. American Journal of Science, volume 35, pages 633-636. Stanford Expedition to Brazil, volume I, pages 49-52. Stanford University, 1914.

Charles A. White: Contribuicões a Paleontologia do Brasil (com o original em inglez). Archivos do Museu Nacional, volume VII, $4^{\circ}$, paginas $1-273$ and 28, plates. Rio de Janeiro, 1887. 350 copies of this report were issued as a special edition, dated Washington, January 21, 1888, under the title: "Contributions to the paleontology of Brazil," comprising descriptions of Cretaceous invertebrate fossils, mainly from the provinces of Sergipe, Pernambuco, Pará, and Bahia.

A. SMith Woonward: Notes on some Vertebrate fossils from the Province of Bahia collected by Joseph Mawson, Esq., F. G. S. Annals and Magazine of Natural History, 1888, pages 132-136.

A. Smith Woodward: Evidence of the occurrence of Pterosaurians and Plesiosaurians in the Cretaceous of Brazil, discovered by Joseph Mawson. Annals and Magazine of Natural History, sixth series, volume 8, pages' 314317, 2 figures. London, 1891.

A. SMITH Woodward: On two deep-bodied species of the clupeoid genus Diplomystus. Annals and Magazine of Natural History, sixth series, volume XV. London, 1895.

A. Sмith Woonward: On the quadrate bone of a gigantic Pterodactyle discovered by Joseph Mawson in the Cretaceous of Bahia, Brazil. Annals and Magazine of Natural History, sixth series, volume 17, pages 255-257. London, 1896.

ARThUR SMrTh Woodward: On some fossil fishes discovered by Prof. Ennes de Souza in the Cretaceous formation at Ilheos, State of Bahia, Brazil. Quarterly Journal of the Geological Society, volume LXIV, pages 258-362 (2 plates). London, August, 1908.

A. Smith Woodward: On an Amiold fish, Megalurus mawsoni, sp. n., from the Cretaceous of Bahia, Brazil. Annals and Magazine of Natural History. seventh series, volume IX, pages 87-89, 1 plate. London, 1902.

\section{CFARA}

Previous investigations. - The base map of Ceará is copied from the map of that State made by the Inspectoria de Obras Contra as Seccas under the direction of Dr. M. Arrojado R. Lisboa.

Fairly comprehensive reports have been made of late years on the general geology of Ceará by Crandall, Small, Waring, and Soper. Earlier valuable notes are those of Capanema, George Gardner, Pompeu de Souza, and Spix and Martius. The noted Cretaceous fossil fishes are described by L. Agassiz, and lately Dr. D. S. Jordan has prepared a full report on them for the Serviço Geologico do Brasil. The report has not yet been published. 
General geology.-The surface rocks over most of the State of Ceara are the granites, gneisses, and schists of the Brazilian complex. Along the western frontier the Serra Grande mountain range is of sedimentary rocks that have been called lower Permian by Small and Cretaceous by Crandall. The Araripe range, which lies along the southern boundary, is Cretaceous, while the entire coast is bordered by a narrow belt of Tertiary sediments. The Archean of Ceará is cut at many places by intrusives, and faults have let down into the granites and gneisses the ends of some of the old sedimentary beds that now appear in the topography as ridges of quartzites. A typical instance of this structure is shown in the

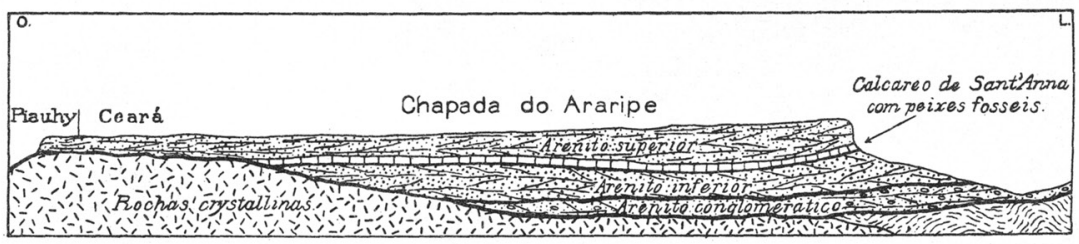

Secção ŝeologica mostrando a estructrua da Chapada do Araripe. Conforme H.L.Small.

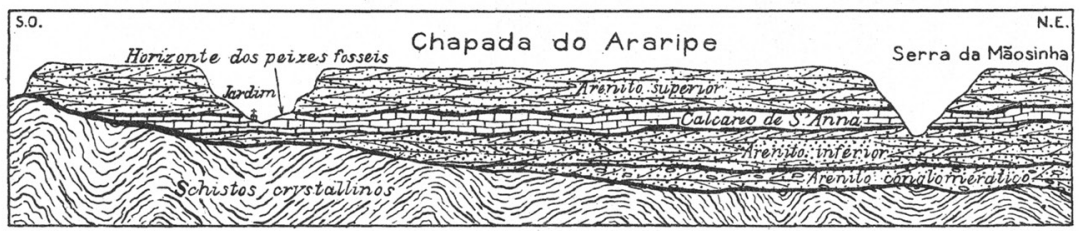

Secção f́eolo óica.da Chapa da do Araripe entre Serra da Mãosinha e Jardim. Conforme H.L.Small.

FIGURE 11.-Two Sections showing the geologic Structure of the Chapada do Araripe, in southern Ceará

The fossil fishes are from the Sant'Anna limestone.-H. L. Small.

Serra de Tucunduba, whose geology is given in the report of H. L. Small opposite page 46 . There are also a few isolated infolded or infaulted fragments of some of the newer rocks scattered over the Archean area.

The Lower Permian-the "Serra Grande series" of Small-forms the eastern escarpment of the Serra Grande, a range of mountains on the western frontier, extending from near the ocean on the north to seven degrees south latitude, nearly to the Serra do Araripe. The rocks of the Serra Grande are coarse calcareous sandstones, limestones, and conglomerates, usually false-bedded, and having a maximum thickness of 700 meters just west of the town of Ipú. For the most part the dip of these beds is from four to seven degrees toward the west or northwest. No fossils have been found in the Serra Grande rocks, and the age of the. 
series is not certainly known. They are referred tentatively to the lower Permian by Mr. Small, chiefly because beds known to be Permian overlie them on the west: There are several outliers, supposed to be of the same age as the Serra Grande rocks, at and north of Serra da Rola on Rio Acarahú. The rocks of the Serra da Rola itself dip northward, and several kilometers down the river the dip is to the south. There are a good
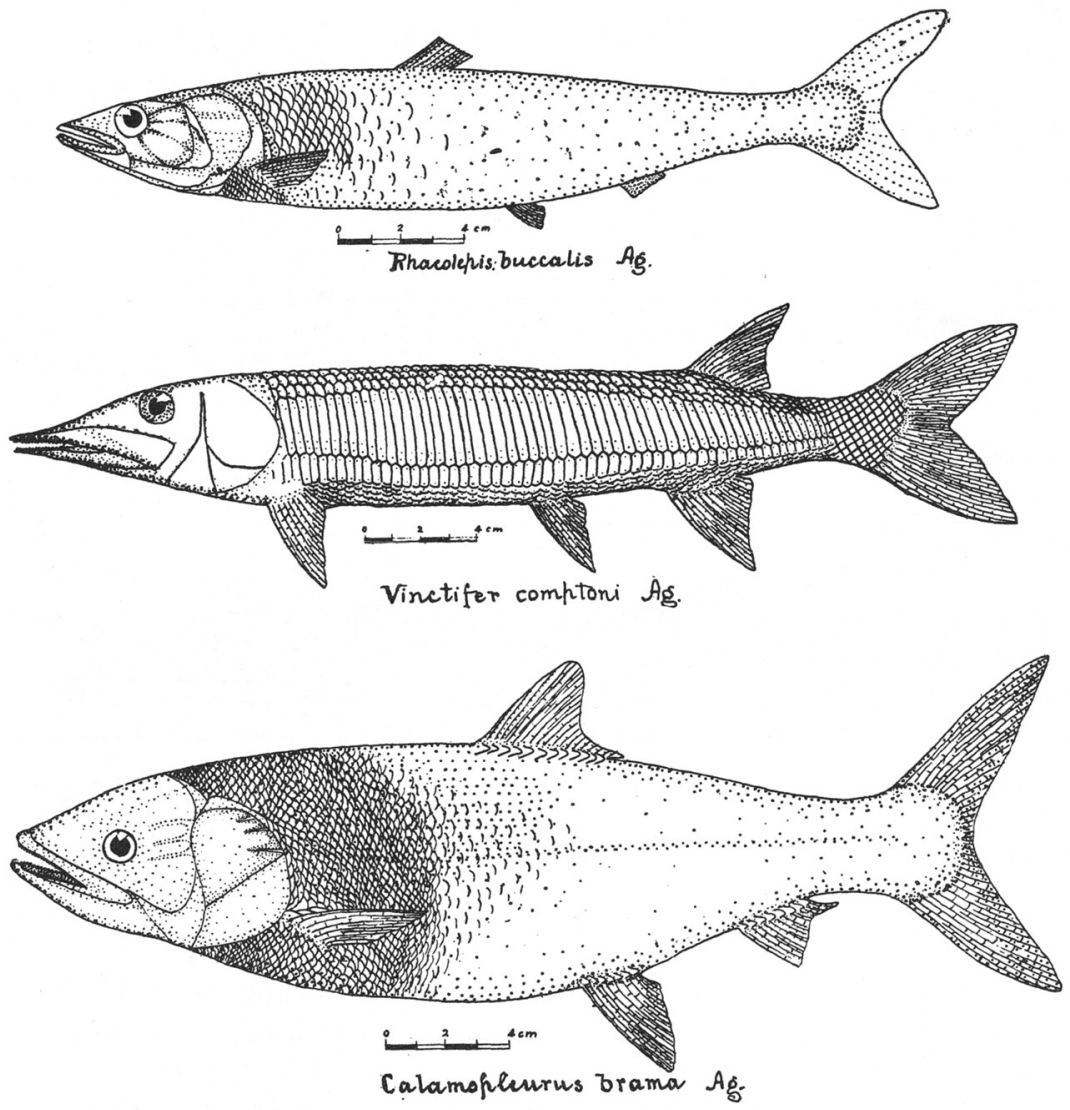

FIgURE 12.-Cretaceous Fishes from the Serra do Araripe

Restored by D. S. Jordan.

many caves in the limestones of the Serra Grande series, the best known of which is the Gruta de Ubajárra, 13 kilometers northeast of Itiapina.

The Serra or Chapada do Araripe, on the southern frontier of Ceará, is a flat-topped tableland of nearly horizontal Cretaceous rocks. The two accompanying sections by Small show the general features of the geology and dispense with the necessity of further description. In the bed called 
the "Sant'Anna limestone" fossil fishes are found that show satisfactorily the Cretaceous age of this series.

The irregular zone of coastal sediments shown on the map as Pliocene extends along the entire coast and varies in width from 5 to 35 kilometers. The rocks are mostly soft reddish, yellow, and mottled sandstones and clays in which no fossils have yet been found in Ceará. The Tertiary beds all dip gently toward the ocean. Some of the beds contain much iron locally. They are assumed to be Pliocene because there is a lower series at Mossoró known to be Eocene. The thickness of these sediments varies greatly, but in the State of Ceará they probably do not exceed 50 meters.

At a few places along the coast, notably at Canoa Quebrada, near Aracaty, are short sandstone reefs of Quaternary age, similar to those at Natal and Pernambuco.

Economic geology.-Gold has been washed at many places, but I know of no gold mine now in operation in the state. Iron is abundant at many places, both in the old crystalline series and in later deposits, but it is not mined, and no systematic search has been made for ore bodies worth working. Copper in the form of the carbonate is known at Fazenda Pedra Verde seven kilometers northeast of Viçosa. The deposit is described in Small's report, at page 141. Bituminous shales are found in the Cretaceous rocks of the Serra do Araripe. Books and articles on the state give long lists of minerals found there, but it is not claimed that they are sufficiently abundant to warrant exploitation. White crystalline marble occurs at several places in the interior, and ordinary limestone is abundant along the eastern flank of Serra Grande and in the Serra do Araripe, in the southern end of the state. As the state suffers much from long periodic drouths, subterranean water supply is of great importance in Ceará. Such water is found most certainly in the coastal sediments, though it is occasionally found in small quantities in the Archean area. Data collected by Small show that out of sixty-one wells sunk in the sedimentary beds along the coast $r$ r per cent yielded fairly good water, while out of twenty-three wells sunk in granites, gneisses, or schists 45 per cent only yielded fairly good water (Small, page 56).

\section{Geologic Maps of Ceará}

Crandall and Williams.-In 1910 the "Inspectoria de Obras Contra as Seccas" published a geologic map of the States of Ceará, Rio Grande do Norte, and Parahyba. The authors of the map were Roderic Crandall and H. E. Williams, both, at that time, assistants on the Serviço Geologico e Mineralogico do Brasil. The map was on a scale of 1 to $3,000,000$ 
and five divisions of the geologic column were represented, namely: (1) granites, (2) gneisses and crystalline schists, (3) the Ceará series, which is not well defined, but seems to belong with the gneisses and schists; (4) Cretaceous, and (5) Quaternary. This map is called Publication number \%, Series I, G of the Inspectoria. de Obras Contra as Seccas. It was not accompanied by text, but Mr. Crandall's report on the geology of that region, published by the Inspectoria as number 4, Series I, D, E; may be accepted as the text.

\section{Bibliography of the Geology of Ceará}

Louis Agassiz: On the fossil fishes found by $\mathrm{Mr}$. Gardner in the Province of Ceara, in the north of Brazil. Edinburgh New Philosophical Journal, volume XXX, pages $82-84,8^{\circ}$. Edinburgh, 1841.

Louis Agassiz: Sur quelques poissons fossiles du Brésil. Comptes Rendus de l'Academie des Sciences, volume XVIII, pages 1007-1015. Paris, 1844.

Louxs Agassiz : Recherches sur les poissons fossiles. Neuchatel, 1833-1843.

T. C. Branner : Fluting and pitting of granites in the tropics. Proceedings of the American Philosophical Society, volume III, pages 163-174. Philadelphia, 1913.

Guilherme S. DE Capanema: Trabalhos da Commissão Scientifica de Exploração. Parte I, introducção. Secção geologica, pages cxx-cxliii. Rio de Janeiro, 1862.

R. Crandatix: Geographia, geologia, . . nos estados orientaes do norte do Brazil, Ceara, etc. Publicação 4. Inspectoria de Obras Contra as Seccas. Rio de Janeiro, 1910.

João da Silva Feiso: Memoria sobre Mineraes de Ferro de Cangaty do Xoró na Capitania de Ceará escripta no anno de 1814, Annexo ao Relatorio do Ministro da Agricultura, 8 pages. Rio de Janeiro, 1864. Partly republished in Chorographia da Provincia do Ceará, por José Pompeu de A. Cavalcanti, paginas 64-66. Rio Janeiro, 1888.

George Gardner: On the geology and fossil fishes of north Brazil. Report of the British Association for the Advancement of Science for 1840. Transactions, paginas 118-120. London, 1841.

George Gardnar: Peixes petrificados que se achão na Provincia do Ceara. Jornal do Commercio, No. 95, 9 de Abril de 1842. Published as an appendix to Boubée's Geologia Elementar, paginas 54-55. Rio de Janeiro, 1846.

GEORGe GARDNER: Reisen in innern Braziliens, besonders durch die nördlichen Provinzen und die Gold-und Diamanten-districte. Aus dem Engl. von M. B. Lindau. Two volumes, $1 \mathrm{map}, 8^{\circ}$. Dresden und Leipzig, Arnold, 1848.

George Gardner: Travels in the interior of Brazil during the years 1836-1841. $8^{\circ}$, xvi +562 pages. London, 1846 . Second edition, xviii +428 pages. London, 1849.

D. S. Jordan and J. C. Branner: The Cretaceous lishes of Ceara. Smithsonian Miscellaneous Collections, number 1793, volume LII, pages 1-29. Washington, 1908. 
Fenry Koster: Travels in Brazil. Second edition. In two volumes. London, 1817. A few notes on the geology of Pernambuco, Parahyba, Rio Grande do Norte, and Ceara, volume I, pages 152-258.

Marcos Antonio de Macedo : Descripção dos terrenos Carboniferos da Comarca do Crato. Bibliotheca Guanabarense. Trabalhos da Sociedade Vellosiana, paginas 23-28. Rio de Janeiro de 1855.

Thomaz Pompeu de Souza Brazil: Ensaio Estatistico da Provincia do Ceará. Caput IV, Aspecto physico, pages 9-26. Caput X, Constituição geologica. paginas 41-55. Saltpeter, page 350, $8^{\circ}$. [Fortaleza ?], 1863.

Dr. Jos A Americo dos Santos: Pogo artesiano. Revista de Engenharia, 14 de Junho de 1889, volume XI, pagina 131. Rio de Janeiro, 1889.

H. L. SMALL : Geologia e supprimento d'agua subterranea no Ceara, etc. Pubs. 25 and 32 da Inspectoria de Obras Contra as Seccas. Rio de Janeiro. Brazil, 1913 and 1914.

A. SMITH Woodward: On the fossil teleostean genus Rhacolepis Agassiz. Proceedings of the Zoological Society of London, 1887, pages 535-542.

A. Smith Woodward: Catalogue of the fossil fishes in the British Museum, parts III and IV. London, 1889.

A. SMITh Woodward: On some Upper Cretaceous fishes of family Aspidorhynchidæ. Proceedings of the Zoological Society of London, 1890, pages 629636.

\section{ESPIRITO SANTO}

Previous investigations.-The geology as shown on the map is largely from the personal observations of the author. Publications regarding the geology of the state are limited almost entirely to the notes of Hartt, two short papers by Freise, and the very few notes by Maximilian WiedNeuwied. Auguste St. Hilaire, the French botanist, crossed the state, but he has very little to say about the geology.

General geology.-The general geology of the State of Espirito Santo is quite simple: Archean gneisses, granites, and schists form the mountains and high western part of the State and of most of the interior; Pliocene (?) and later sediments form a belt along the coast and lap back over and against the Archean rocks. Little is known of the details of the geology of the State, but it is probable that quartzites and old metamorphic rocks are here and there let down into the older masses by faulting.

There are two and possibly three divisions of the coastal sediments: an older, basal division, in which no fossils have yet been found, and a later division, of soft and incoherent yellow sands and clays, blackened here and there by iron or vegetable matter or bleached by acidulated waters, containing marine fossils, separated from the older division by an unconformity.

These Tertiary beds all dip gently toward the ocean. They probably do not exceed fifty meters in thickness, and are cut entirely through along 
Rio Mucury and in Lagoa Juparanã, where the underlying granite is exposed.

The Tertiary belt is about eighty kilometers wide at São Matheus, near the north end of the state, and narrows to a width of about twenty kilometers at the south end, while at several points between, notably at Benevente and at Victoria, these Tertiary sediments have been completely removed by denudation.

About the mouth of Rio Doce is a large area of swampy lands that should probably be regarded as recent alluvial deposits rather than Pliocene.

Economic geology.-But little is known of the mineral resources of the State of Espirito Santo. Rocks of the Brazilian complex cover most of the State, and within that area many of the minerals common to Brazil have been found. Friese reports finding wolframite in the Serra dos Aymores north of the Rio Doce. Monazite sands are found along certain parts of the sea beaches north of Victoria. Limestones (probably marbles) are said to cover a considerable area in the Valley of Rio Castello.

\section{Geologic Map of Espirito Santo}

Pissis, 1842.-The map accompanying the Mémoire sur la position géologique des terraines de la partie australe du Brésil, par M. A. Pissis, Paris, 1842, includes the geology of the entire State of Espirito Santo. The map is on a scale of 1 to 2,500,000, but it does not show evidences of much work done in the State of Espirito Santo.

\section{Bibliography of the Geology of Espirito Santo}

herminlo Candido da Costa Alves: Estrada de ferro da Victoria para Minas. Relatorio, etc., paginas 19-22. Rio, 1876.

F. Frerse: Die Monazitseisen. Zeitschrift für Praktische Geologie, volume XVII, 1909, pages 514-522.

F. Freise: Uber einige Mineralverkommen du sịdlichen Serra dos Aymorés. Zeitschrift für Praktische Geologie, volume XVIII, pages 143-146.

C. F. HartT: Geology and Physical Geography of Brazil. Boston, 1870. (Espirito Santo, pages 56-124.)

Prinz zu Wied-Neuwied MaximiLIan : Reise nach Brasilien, 1815-17. Mit 2 Bde. Atlas folio. Frankfurt, 1820-1821.

Voyages au Brésil, dans les annés 1815-1816 et 1817. Par S. A. S. Maximilian, Prince de Wied-Neuwied; traduit de l'Allemand par J. B. B. Eyriès. Paris, 1812, xiv +399 pages; tome 2 nd, 1821, iii +400 pages; $3 \mathrm{me}, 1822$, ili +384 . (Contain notes on the geology between Rio and Bahia.) About half of this work was translated into English under the title "Travels in Brazil in the years 1815, 1816, 1817." By Prince Maximilian, of Wied-Neuwied. London, 1820. $4^{\circ}$, viii +335 pages. (This is 
all that was translated and includes volume $I$ of the French edition and chapter XI of volume II, up to page 206.)

J. W. Rich ardson: The Espirito Santo and Bahia Monazite beds. Brazilian Mining Journal, volume I, pages 79-84. Rio de Janeiro, July, 1903.

Auguste de SaInT-HILaIRe: Voyage dans le district des diamans et sur le littoral du Brésil. Two volumes, 12mo. Paris, 1833.

GOYAZ

Previous investigations.-The base map of Goyaz is made up partly from the coordinates along the Rio Araguaya by Dr. W. Berky for the Department of Terrestrial Magnetism of the Carnegie Institution and partly from the map of the Commissão de estado da Nova Capital da União, under Dr. L. Cruls, Rio, 1896.

The location of the Tocantins and the Paranãn is taken from the Brazilian government's map of the prolongation of the Estrada de Ferro Central do Brasil do Rio a Belem, $191 \%$.

The report of the expedition of Castelnau across Goyaz and of his trips on the Araguaya and Tocantins contains many notes on the geology, though it is often difficult to locate the places mentioned. George Gardner's travels and Pohl's Gebirgskunde Brasilien are also very helpful.

The report of Cruls on the Planalto Central do Brazil has important notes on the mineralogy, and on the geologic structure, by Hussak.

In the northwest corner of Goyaz, where it touches the State of Pará, I have felt obliged to omit the Cretaceous beds along the Araguaya, as shown by. Katzer in his map of the geology of Pará.

General geology.-The Archean rocks in the State of Goyaz extend from Rio Parnahyba, southwest of Santa Rita do Parnahyba, and from, south of Catalão northward past Bella Vista, Pyrenopolis, and the city of Goyaz to Porto Nacional, on the Rio Tocantins-a distance of more than eight hundred kilometers. This Archean belt has a width of four hundred or five hundred kilometers, more or less. The details of the outlines of the area shown on the map, however, make no claim to accuracy, while the limits of the Archean along the western side of the state are almost entirely unknown. There are a few small Archean areas exposed where the overlying rocks have been removed by denudation. One of these is reported by Gardner at Natividade. There appear to be areas of infaulted old Paleozoic rocks within the area of Archean rocks in the region about the city of Goyaz and elsewhere, but, for lack of a knowledge of details, it is quite impossible to outline any of them at present.

There seems to be an area of old Paleozoic rocks about the headwaters of Rio Araguaya, but very little is known either of the character of the 
rocks or of the area covered by them. Castelnau speaks of them as much contorted argillaceous schists dipping south and southeast. ${ }^{49}$

The summit of the divide in the new federal district northeast of Pyrenopolis and west of Formosa is capped by sedimentary rocks that I have referred provisionally to the Upper Permian. These rocks extend southward along the divide between Rio São Marcos and Rio São Bartholomeo and appear to connect with the Upper Permian in Minas Geraes near Patrocinio. To the north of Formosa these same sedimentary beds form the great plateau along the watershed to the north, between the States of Goyaz and Bahia, to and beyond the frontier with Maranhão and Piauhy.

In the vicinity of Pyrenopolis these Permian sediments are a mere remnant, but farther north they spread out until they have a width of 600 kilometers or more in the northern part of the State of Goyaz.

The notes of George Gardner show that the rocks are about horizontal, and that they are mostly sandstones and limestones.

Inasmuch as there are cavernous limestones in the Serra do Roncador in northeast Matto Grosso, it seems probable that these beds extend quite across northern Goyaz into the States of Pará and Matto Grosso.

The map shows an area of Triassic rocks in the southwestern part of the State of Goyaz. Triassic rocks are known in the adjoining States of São Paulo and Minas Geraes, and it is inferred that the similar beds on the northwest side of Rio Paranagua are also Triassic. The precise locations of the margins of the Triassic rocks in the State of Goyaz, however, are not known at present.

Overlying the Triassic rocks in the southwest corner of the State is a later series of sediments supposed to be of Cretaceous age. The only notes we have of this series are those of Castelnau, who crossed them on the road leading from Goyaz to Cuyabá, in the State of Matto Grosso. The drawings and photographs given by Henry Savage-Landor at pages 253, 256, and 352 of his "Across Unknown South America," Boston, 1913, give a vivid idea of the topography and structure..$^{50}$

Economic geology.-Goyaz has produced notable quantities of gold, chiefly from placer deposits where it is derived from schists. Diamonds and other precious stones have also been mined, especially along Rio Claro, an affluent of the upper Rio Araguaya. Iron, both magnetic ore and hematite, is reported from many places in the State, but very little is known as yet about the quantity available. Hussak mentions one bed,

\footnotetext{
4 Expedition . . . histoire du voyage, vol. 11, p. 248. Paris, 1850.

${ }^{50}$ Unfortunately that author's statements about lavas are not to be trusted. The rock so named by him is mostly the well known canga or limonite iron ore, while the "lava over giant volcanic dome" at page 270 is an exfoliated mass of sandstone.
} 
30 meters thick, near Meia Ponte (now called Pyrenopolis). Dr. Lisboa mentions the occurrence of bituminous and gypsiferous shales at the confluence of Rio Sereno with Rio Manoel Grande in the Tocantins lowlands. ${ }^{51}$

\section{Bibliography of the Geology of Goyaz}

Francis de Castelnau: Expedition dans les parties centrales de l'amérique Sud, de Rio de Janeiro á Lima, et de Lima au Pará, . . . pendant les années 1843 à 1847 sous la direction de Francis de Castelnau. Histoire du voyage, six volumes and atlas. Paris, 1850, 1851.

L. Cruls et Dr. Antonio Pimental: Commission d'exploration du Plateau central du Brésil. Rapport presenté á son Exc. le Ministre de l'Industrie. Annexe 4. Rapport du Dr. Antonio Pimental; Géologie du Plateau central du Brésil, etc. Two fascicles, 365. pages. Abstract of geology and geography under title: "Explorations in Central Brazil." The Geographical Journal, volume IX, paginas 64-67. London, January, 1897.

George Gardner: Travels in the interior of Brazil, principally through the northern provinces and the gold and diamond districts, during the years 1836-1841. $8^{\circ}$, xvi +562 pages. London, 1846. Second edition, xviii + 428 pages, map and plate, $8^{\circ}$. London, 1849. (Goyaz, pages 244-293.)

E. Hussak : Ueber ein neues Perowskit-Vorkommen in Verbindung mit Magneteisenstein von Catalão. Stáat Goyaz, Brasilien. Neues Jahrbuch für Mineralogie, 1894, volume II, pages 297-300.

F. Hussak : Estructura geologica do Estado de Goyaz. Relatorio Parcial da Commissão Exploradora do Planalto Central do Brazil, paginas 111-130. Rio de Janeiro, 1893.

F. HUssak : Diamantlager im Westen des Staates Minas, São Paulo und Goyaz, Brasilien. Zeitschrift Praktische Geologie, Okt., 1906, volume XIV, pages 318-333.

Couto de Magalhães: Primeira viagem ao Araguaya. São Paulo, 1889.

R. Joś DA C. MAtTos: Itinerario do Rio de Janeiro . . . pelas provincias de Minas Geraes e Goiaz, etc. Two volumes. Rio de Janeiro, 1836.

Raymundo Jose da Cunha Mattos: Chorographia historica da provincia de Goyaz. Revista do Instituto Historico, volume XXXVII, Parte I. Rio de Janeiro, 1874. Tomo XXXVIII, Parte I. Rio de Janeiro, 1875.

Francisco de Paula Outverra: Vista geral sobre o aspecto physico da região do Novo Districto Federal e dos valles dos rios Corumbá e S̃̃o Bartholomeu, em Goyaz. Relatorio parcial, Commissão de Estudos da Nova Capital da União. Geologia, G. 3 to G. 8. Rio de Janeiro, 1896.

Јон. Ем. Ронц: Beiträge zur Gebirgskunde Braziliens. Wien, 1832.

J. E. PонL: Reise im Innern von Brasilien. Wien, 1832.

SPIX und Martius: Reise in Brasilien, volume II, pages 559-593. München, 1828.

E. J. C. VALlEe: Exploração do Rio de Araguay. a Annexo (letra P) ao Relatorio do Ministro de Agricultura, etc., 1886, paginas 15-33.

J. W. WeLcs : Three thousand miles through Brazil. Two volumes. London, 1886. (Goyaz, volume II, pages 148-250.)

51 American Journal of Sclence, May, 1914, vol, xxxvil, p. 439. 


\section{MARANHAO}

Previous investigations.-In the preparation of the geographic base for the State of Maranhão I have had the benefit of the coordinates determined by Dr. Arnaldo Pimenta da Cunha and published in the Boletim Official do Ministerio da Industria, Viação e Obras Publicas, $1^{\circ}$ anno, tomo II, page 158, Rio de Janeiro, 1909.

The most valuable papers on the geology of Maranhão are those of Dr. M. Arrojado R. Lisboa, the notes of Spix and Martius, and those of James W. Wells. The interior of the state is but little explored. On the lower Tocantins I have followed Castelnau by referring his sandstones and shales to the Permian of Lisboa.

General geology.-Archean rocks are known in Maranhão along Rio Gurupy, on the lower portion of the Tury-assu, and along a short piece of Rio Itapicuru between Codó and Coroatá. It is possible that there is also a belt of Archean exposed along Rio Grajahú near four degrees south latitude, where Wells reports a hard dark "greenstone" very similar to that at Chapada. ${ }^{2}$

The oldest known rocks in Maranhão after the Archean are supposed to be the Permian sediments, which cover nearly half of the state. These Permian beds, as described by Dr. Lisboa, are here mentioned in their natural order:

\section{Unconformity at the Top of the Permian}

Thickness in
meters

meters

7. Green and chocolate-colored shales, limestones, and white sandstones.
6. São Bartholomeu sandștone, ashen gray, false-bedded...........

5. Pisolitic rock, mostly white sandstone.................. ?

4. Jaboti red sandstone, with purple spots.................... \pm 150

3. Mendes sandstone, ashen gray to white....................

2. Ashen gray marly shales and calcareous beds................ ?

(Interval not seen.)

1. Bituminous shales.

These sedimentary beds are nearly horizontal, and are cut here and there by dikes and interstratified with sheets of diabase.

Next above the Permian beds is the Mearim series of Lisboa, and provisionally referred by him to the Triassic. These beds are principally red sandstones having a thickness of 100 meters. In places they contain flows of amygdaloidal trap.

In the Serra Vermelha above the city of Grajahú these beds dip locally west-northwest, and the red sandstone, with the included trap, has a thickness of 235 meters.

52 J. W. Wells : Three thousand miles through Brazll, vol. 11, p. 291. London, 1886. 
A soft yellow sandstone that overlies the Triassic and forms the top of the plateau of Grajahú is referred by Lisboa to the Cretaceous. In places these sediments are argillaceous; the whole series dips gently toward the coast.

Along the coast of Maranhão is the Tertiary zone characteristic of the coast of northern Brazil. These beds are horizontal sediments, here and there cemented with iron. Where the sea is encroaching on them they form bluffs, and where the sands are encroaching on the sea the coast is low and the hard rocks are covered by sand-dunes.

It was formerly supposed that the marine fossils found at Pirábas, on the coast of Pará, we Cretaceous, and they were therefore included in Dr. C. A. White's description of the Cretaceous fossils of Brazil. Later studies have shown that those fossils are Eocene. ${ }^{52}$ Reference is here made to the Pirábas fossils because Dr. Lisboa found at Carutapera, in the northwest corner of Maranhão, fossiliferous limestone "with a fauna similar to that of Pirábas." The Carutapera region is therefore to be classified as Eocene unless a fuller study of the fossils found there should warrant a different conclusion.

Economic geology.-But few minerals of economic importance are certainly known in the State of Maranhão. Some gold has been mined; bauxite is reported in the sedimentary beds of the west, and Dr. Lisboa found bituminous shales near Codo and at several other places in the atate. Burlamaqui reports such shales on Rio Mearim near Barra do Corda. Limestone, probably of Permian age, is abundant on Rio Grajahú, where it has a thickness of 25 meters. Iron has long been reported from the island of $\mathbf{S}$. Luiz, but there is no information available regarding the quantity and quality of the ore.

\section{Geologic Map of Maranhão}

Lisboa, 1914.-Dr. M. A. R. Lisboa published, in the American Journal of Science for May, 1914 (volume 18\%, pages 425-443), an article on the Permian geology of northern Brazil, and accompanying it was a small map showing the geology of a large part of the State of Maranhão. It is on a scale of 1 to $1,126, \% 60$, and four geologic divisions are represented, namely : crystalline, Permian, Triassic, and Cretaceous.

\section{Bibliography of the Geology of Maranhão}

Anon : Mines d'or . . . pres de Saint Louis de Maranhão. Nouvelles Ann. des Voyages, sixth series, volume II, pages 112-114. Paris, 1885.

\footnotetext{
62 Cariotta Joaquina Maury : A contribution to the paleontology of Trinidad. Jour. Acad. Nat. Scl. of Philadelphia, vol. xv, pp. 32-33. Philadelphia, 1912.
} 
F. Burlamaqui : Noticia acerca de alguns mineraes, etc. Revista Brazileira, volume II, paginas 76-77. Rio de Janeiro, 1859.

Mrauel A. R. Lrsboa: The Permian geology of northern Brazil. American Journal of Science, May, 1914, pages 187, 425-443.

Fernand Perourde: A propos des Psaroniees du Brésil. Comptes Rendus de l'Association française pour l'Advancement des Sciences, 1914, pages 442445.

SPIX und MARTIUs: Reise in Brasilien, volume II, pages 835-884. München, 1828.

J. W. WELLs: Exploring and traveling three thousand miles. Two volumes. London, 1886. (Maranhão, volume II, pages 259-306.)

J. W. WeLLs : Notes of a journey . . . to the city of Maranhão. Journal of the Royal Geographical Society, volume XLVI, pages 308-328. London, 1876.

\section{MATTO GROSSO}

Previous investigations.-The base map of Matto Grosso is made up chiefly from the following data:

1. Locations along Rios Guaporé and Madeira by R. H. Schmidt, of the Department of Terrestrial Magnetism, Carnegie Institution.

2. Rios Gy-Paraná, Theodoro, and the Tapajos are copied from the map given in the lectures of Colonel Candido Mariano da Silva Rondon, published at Rio de Janeiro in 1916.

3. Rio Xingú is from the maps of Karl Von den Steinen's Erforschung des Xingú.

4. The southern part of the State is from Schnoor's map, given in Dr. M. A. R. Lisboa's paper in "Oeste de São Paulo, Sul de Matto Grosso. Geologia," etcetera. Rio de Janeiro, 1909.

Castelnau gives the geology along the routes followed by his expeditions from Goyaz to Cuyabá and thence to Villa Bella. Evans' paper on the region northwest of Cuyabá is valuable; the geologic notes on the Xingu by Dr. Vogel and by Clauss and the occasional notes given by J. S. da Fonseca are helpful.

The notes of Euzebio Paulo de Oliveira on the "Expedição RooseveltRondon" and those of Alberto B. Paes Leme after the notes of Cicero de Campos are most welcome additions. The most valuable late contribution to the general geology of Matto Grosso is by Dr. M. Arrojado R. Lisboa, who crossed the southern end of the state from São Paulo to Curumbá, along the line of the new railway route.

The best general description of the state is that by Herbert H. Smith.

On the paleontology Clarke, Knod, and Von Ammon are most important.

General geology.-Geologically Matto Grosso is the most. interesting and the least known of the Brazilian states. The available notes and 
observations on its many geologic problems are unusually difficult to harmonize, and the results as shown on the map must not be regarded as anything more than an effort to bring them into accord with each other and with what is known of the geology of adjoining regions. The few notes I have been able to find on the geology along the Rio Guapore are by Dr. João Severiano da Fonseca. ${ }^{53}$ The geology along the Gy-Paraná and the Rio Theodoro is chiefly from the notes and reports of Euzebio Paulo de Oliveira. ${ }^{54}$ The general geology of the Serra do Norte and of the plateau west of Diamantino is also chiefly from his paper.

The Parecis sediments (Cretaceous?) are shown on the map as crossing Rio Tapajos about seven degrees south latitude, in accordance with the notes of Chandless. ${ }^{85}$ On the upper Xingú we have a very few notes in the papers of Dr. P. Vogel ${ }^{56}$ and of Otto Clauss. ${ }^{57}$ The Parecis sandstone of the plateau is referred provisionally to the Cretaceous, in accordance with the suggestion of Euzebio Paulo de Oliveira, though, as he points out, no fossils characteristic of that age have yet been identified from that series. ${ }^{58}$ This agrees also with an earlier suggestion of Derby, made in 1895 and based on vertebrate remains found in the horizontal sandstones north of the Chapada. ${ }^{59}$

The geology of the southwestern part of the state is chiefly from the report of Dr. M. A. R. Lisboa. ${ }^{\text {Bo }}$ Some light is to be had on that part of the state, however, from what has been published on the geology of Paraguay. Near Villa Rica Stereosternum tumidum, ${ }^{61}$ a fossil characteristic of the Upper Permian of Brazil, has been found, while in the mountains of northeastern Paraguay have been found Productus and Spirifer poststriatus, fossils characteristic of the Permian. ${ }^{62}$ These fossils suggest the possibility of the "Bodoquena" of Dr. Lisboa being Permian, in part at least. ${ }^{63}$

s3 Viagem ao redor do Brazil, vol. li. Rio de Janeiro, 1881.

54 Reconhecimento geologico do Noroeste de Matto Grosso.

₹ W. Chandless: Notes on the rivers Arinos, Juruema, and Tapajos. Journal Royal Geographical Society, vol. xxxil, pp. 268-280. London, 1862.

${ }^{\overline{6}} \mathrm{P}$. Vogel : Reise in Matto Grosso, 1887-8. Zeit. der Gessellschaft für Erdkunde zu Berlin, xxvili, Berlin, 1893 ; also In Von den Steinen's Erforschung des Xingu : durch Zentral-Brasilien, Leipzig, 1886.

${ }^{57}$ Otto Clauss: Bericht uber die Schlngu-Expedition, 1884. Petermann's Mitthell., vol. 32, 1886, pp. 129-134, 162-168.

ss Expedição scientifica Roosevelt-Rondon. Annexo no. 1 Geologia, pp. 33, 76. Rio de Janeiro, 1915.

to Archivos do Museu Nacional, vol. ix, p. 63. Rlo de Janeiro, 1895.

o Oeste de São Paulo, Sul de Matto Grosso. Geologia, etc. Rio de Janeiro, 1909.

${ }^{61}$ F. Frech : Lethea Geognostica, Th. 1, 2 Bd., Lief 3, p. 460.

az Jos. จ. Siemiradski : Geologische Reisebeobachtungen in Sifdbrastlien. Sitz. Akad. Wiss. Wien, vol. cvil, January, 1898, pp. 38-39.

os This is still further strengthened by a report of fossil ferns sald to have been found near Miranda by Lloyd and eited by Evans. Quarterly Journal of the Geological Society of London, p. 97. Lohdon, 1894. This announcement seems to have been discredited. and I have not yet been able to verify the statement. 
The northeast corner of Matto Grosso, where it joins Pará and Goyaz, has not been explored geologically. Katzer represents the adjoining part of the State of Pará as Cretaceous, but I do not find that any work has been done in that area. Paul Fountain, who traveled in the Xingú basin and along Rio Fresco and in the mountains east of there, reports in those mountains extensive caverns with abundant stalactites. ${ }^{64}$ Of course, the limestones might be of any age from Archean to Cretaceous, but, in the absence of data to the contrary, it seems reasonable to suppose that they are of the same age as the Permian limestones east of the Tocantins, and I have therefore so represented them, subject to correction.

The foothills east of the great marshes of the Paraguay, north of Aquidauana, past Coxim, and northward nearly to 15 degrees south latitude, Dr. Lisboa marked on his map as Mesozoic with a question. ${ }^{85}$ No fossils have been reported from these beds, but $I$ have referred the rocks of this area to the Triassic partly because such reference fits in with what is known of the geology of São Paulo. The part of this zone between Cuyabá and Coxim was crossed by Dr. Vogel, who says the rocks are mostly red sandstones. It is also evident from Castelnau's description that there is a marked change in the topography and the geology where the road from Goyaz to Cuyabá descends from the Matto Grosso plateau at Rio Agua Branca close to 54 degrees west longitude.

The Devonian age of certain beds in the mountains east of Cuyabá has long been known. Vogel was one of those who contributed to our knowledge of that region. In his notes on the geology of the area southeast of Cuyabá he says that certain rocks are similar to the fossil-bearing beds of Taquarassú (Taquarasinhas?), and these last are Devonian beyond question. I have therefore placed in the Devonian the area south of the Chapada as far as Rio São Lourenço. ${ }^{\text {B }}$ The dip of the rocks in the Chapada seems to carry the sandstones beneath the black shales called by Evans the "Matto shales," and these black shales underlie the sandstones of the Serra dos Parecis. It seems possible, therefore, that the shales belong to and form the upper part of the Devonian, much as the Ponta Grossa shales of Paraná overlie the sandstones. I have therefore so placed them provisionally until the question of their age can be more definitely determined. I do not overlook the views of Euzebio Paulo de Oliveira that they may be Permian-views well worthy of serious con-

\footnotetext{
ot Paul Fountain: The River Amazon from its sources to the sea. New York, 1914, pp. 212 and 249-251.

- M. A. R. Lisboa : Oeste de Săo Paulo, Sul de Matto Grosso, Geologia, etc. Rio de Janelro, 1909.

P. Vogel: Relse in Matto Grosso, 1887-8. Zeit. der Gessell. f. Erdkunde zu Berlin, vol. xxvill, 1893, p. 274.
} 
sideration. ${ }^{67}$ The rocks about Cuyabá underlie the Devonian sandstones of the Chapada and were called the Cuyabá slates by Evans. I have personally examined this series at and about Cuyabá and in the region between Cuyabá and Diamantino. I was unable to find any fossils in them in the short time I could give to the work, but inasmuch as the Chapada Devonian beds rest unconformably on them, it is quite evident that they are older than the Devonian and that they are clearly separated from it. I have therefore referred them tentatively to the Silurian, including in this division both the slates exposed at Cuyabá and the zone of folded sediments described by Cicero de Campos as being near São Luiz de Caceres, and by Evans between Livramento on Rio Cuyabá and Barra dos Bugres on Rio Paraguay, and seen by me where it is crossed by the road between Rosario and Diamantino. ${ }^{68}$

The area called older Paleozoic, about the headwaters of Rio Alto Araguaya, in the eastern part of Matto Grosso, is known only from the few notes of Castelnau and Pohl, and those are too brief to be of much service.

That the higher portions of the region between Cuyabá and Rio Paranahyba is Cretaceous is inferred from the following:

1. In São Paulo the Cretaceous overlies the Triassic and forms the hilltops.

2. Dr. Lisboa found outliers of Cretaceous along the railway route between Itapura and Aquidauana. ${ }^{69}$

3. Castelnau's description of the route between Goyaz and Cuyabá shows the Matto Grosso plateau to be of horizontal red sediments, which begin at Serra do Taquara on the east and end abruptly at Serra da Agua Branca on the west. ${ }^{70}$

4. The reference of these beds to the Cretaceous is in keeping with the supposed Cretaceous age of the Parecis sediments.

In a preliminary report by Dr. Lisboa on the manganese and iron mines of Urucum, in the State of Matto Grosso, and dated March, 1918, he gives the following table as the expression of his own views and those of Euzebio de Oliveira in regard to the sequence of the rocks in that state:

or Reconhecimento geologico do Noroeste de Matto Grosso, pp. 74-75. Rio de Janeiro, 1915.

Both Silurian and Devonian are found at Sucre, Bolivia, west of Cuyabk. See Hoek and Stelnmann. Pet. Mitt., 1906. I.

- Oeste de Săo Paulo e Sul de Matto Grosso, mappa.

70 F. de Castelnau : Expédition dans . . . l'Amérique du Sud, Histolre du Voyage, vol. 11, pp. 262-265. Paris, 1850. 


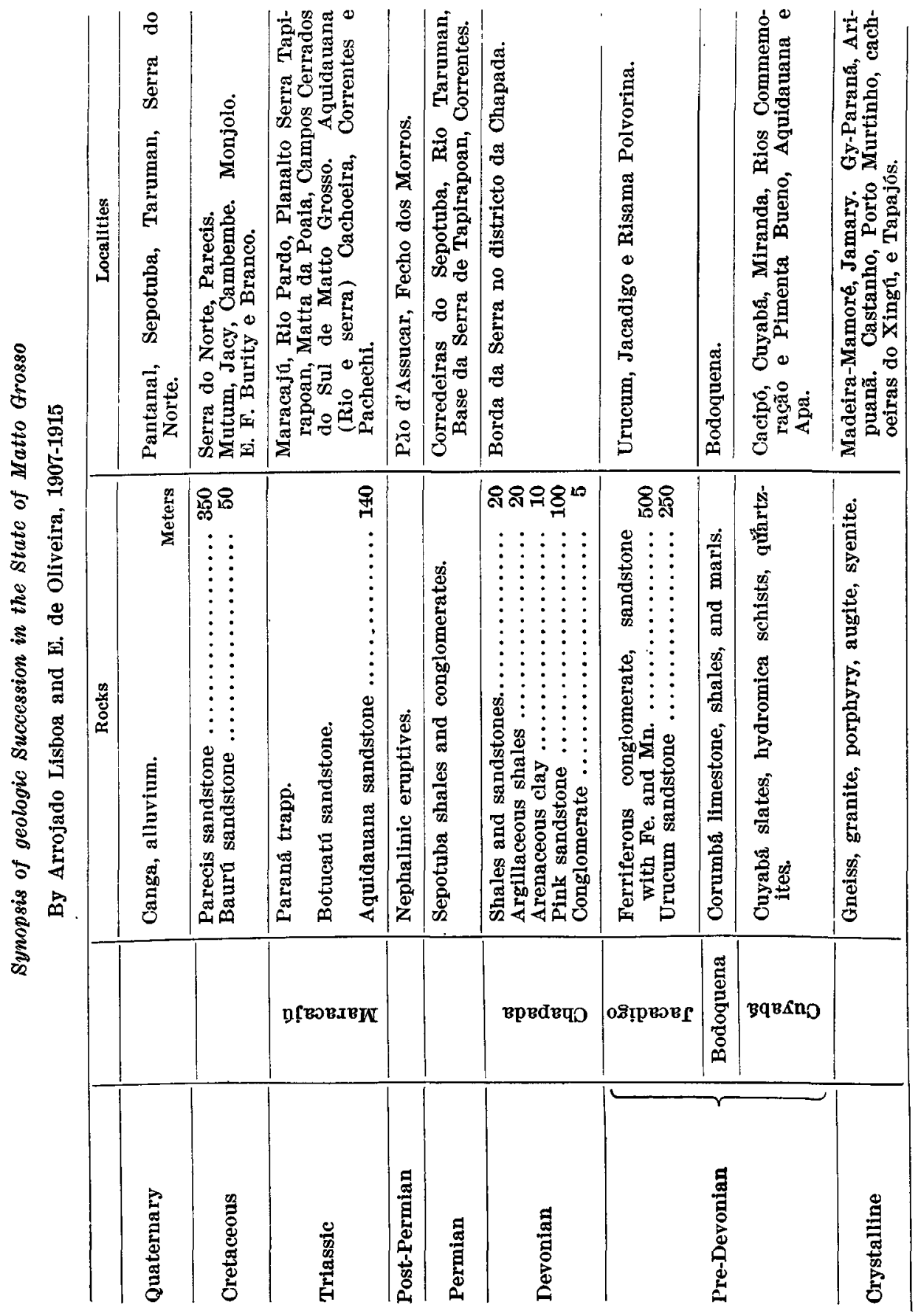


Economic geology.-That the mineral resources of Matto Grosso are but little known is probably due, to some extent at least, to its difficult geographic position and to the fact that the geology of large areas in the state has never been studied. Hitherto it has produced gold and diamonds, and it is probable that gold can be dredged along some of the streams. Iron and manganese are said to exist in large quantities at Urucum (Evans), where they are near river transportation. A description of the geology of the iron and manganese ores shows a remarkable resemblance to that of Minas Geraes. The order of the rocks is as follows, from below upward: gneiss, mica schist, itacolumite, manganese and iron, mica schists, limestone. The beds are mostly horizontal. The hematite iron is said to be from 10 to 15 meters thick and the manganese is from 1 meter to $2.4 .^{71}$

From an unpublished private report on the Urucum mines by Dr. Lisboa, and dated March, 1918, I am permitted to quote his description of the geology:

"In general the Urucum Mountains consist of a series of sedimentary rock to which I gave the name of Jacadigo series in 1907, and which consists of two characteristic formations. The lower one is of rough arkose becoming finer toward the top; the upper one, which is clearly separated from the lower one, consists of ferriferous sandstones. The iron and manganese occur in parallel beds in this upper division."

The Jacadigo series, regarded by Dr. Lisboa as pre-Devonian, is said to have a total thickness of from 250 to 500 meters; the rocks beneath them are granites and mica schists.

The manganese beds he reports as varying in thickness from less than one meter to five meters. His analyses show the manganese ores to run as high as 58.4 per cent of metallic manganese, or 60.8 per cent of manganese and iron together.

\section{Geologic Maps of Matto Grosso}

Evans, 1894.-Dr. J. W. Evans' paper on the geology of Matto Grosso, published in the Quarterly Journal of the Geological Society of London, volume L, pages 85-104, contains a small map showing the general geology of a large area along the Rio Paraguay between Coimbra and Diamantino. The map is on a scale of 1 to 2,500,000 (it is erroneously given on the map itself) and nine divisions of the geology are shown.

Lisboa, 1909.-Dr. Miguel A. Lisboa's report on the geology along the railway route between São Paulo and Matto Grosso, published at Rio

${ }^{71}$ Publio Ribeiro fé H. Kilburn Scott : O manganez no Brazll, p. 18. Rio de Janelro, 1902. 
in 1909 (Sul de Matto Grosso, etcetera), contains a geologic map of the southeastern portion of Matto Grosso. It is on a scale of 1 to $2,000,000$ and shows ten geologic subdivisions. Most of the geology is the original work of Dr. Lisboa himself; it is a contribution of great value to the geology of Brazil.

\section{Bibliography of the Geology of Matto Grosso}

Luiz D'Alincourt : Resultado dos trabalhos e indagações estatisticas da Provincia de Matto Grosso. (Cuyabá, 1828.) Annaes da Bibliotheca Nacional do Rio de Janeiro, 1877-1878, volume III, paginas 68-161, 225-278. Rio de Janeiro, 1877. (Minas e geologia, pages 268-278.)

Cicero de Campos: See Leme, Alberto Betim Paes.

Carl Carnirr: Observações geologicas-geographicas . . Rio de Janeiro, 1909. [Commissão de Linhas telegraphicas estratigicas de Matto Grosso ao Amazonas.] Annexo 5.

F. de Castelnau et Eugene d'Osery: Expedition dans les parties centrales, etc. 5me partie. Paris, 1853.

M. le Comte de Castelnau: Les Diamans dans Matto Grosso. Journal des Debats, Paris, August 10, 1845; also, Revista do Instituto Historico, 1845, pages 567-568. Rio de Janeiro, 1866.

W. CH ANdress: Notes on the rivers Arinos, Juruema, and Tapajos. Journal of the Royal Geographical Society, volume XXXXII, pages 268-280. London, 1862.

George E. ChuRch : The route to Bolivia, pages 179, 186-188. London, 1877.

Oтto Glauss : Bericht ỉber die Schingú-Expedition, 1884. Petermann's Mittheilungen, Band 32, 1886, pages 129-134, 162-168 (with map, profiles, and a few geologic notes).

J. W. Evans: The geology of Matto Grosso, particularly the region drained by the upper Paraguay. Quarterly Journal of the Geological Society, volume L, February, 1894, pages 85-104, map. London, 1894.

J. W. Evans: The rocks of the . . . Madeira. Quarterly Journal of the Geological Society, volume LXII, pages 88-124. London, 1906.

Dr. Joz̃o Severiano da Fonseca : Viagem ao redor do Brazil, 1875, 1878, volume I, royal $8^{\circ}, 399$ pages. Rio de Janeiro, 1880.

Dr. João Severiano da Fonseca: A Gruta do Inferno na Provincia de Matto Grosso, junto ao forte de Coimbra. Rerista Instituto Historico, Tomo XLV, Parte II, paginas 21-34. Rio de Janeiro, 1882.

T. JerrmanN : Diamantino an der Grenze der Zivilisation. Petermann's Mittheilungen, volume XLIX, pages 145-149. Gotha, 1903.

Franz Kellar: The Amazon and Madeira rivers. New York, 1874.

R. KNod: Devonische Faunen Boliviens. Neues Jahrbuch für Mineralogie. Beilage Bd. XXV, pages 493-600. Stuttgart, 1908.

alberto B. Paes Leme: Annexo 5, Historia Natural, etc. Commissão das Linhas telegraphicas de Matto Grosso ao Amazonas. Rio de Janeiro (n. d.) [1911]. (Prepared from the notes of Cicero de Campos.)

M. A. R. Lisboa : Oeste de São Paulo, Sul de Matto Grosso. Geologia, etc. Commissão Schnoor. 172 paginas. Rio de Janeiro, 1909. 
M. A. R. Lrsboa : Les mines de manganese de l'Urucum. Le Messager de São Paulo, Décembre 9, 1918.

R. Jost da C. Mattos: Itinerario do Rio de Janeiro, etc. Two volumes. Rio de Janeiro, 1836.

H. MEYER : Ueber seine Expedition nach Central-Brasilien. Verhandel Gesellschaft für Erdkunde zu Berlin, volume XXIV, pages 172-I98. Berlin, 1897.

H. MEYer : Bericht über seine zweite Xingá-Expedition. Verhandel Gesellschaft für Erdkunde zu Berlin, volume XXVII, pages 112-133. Berlin, 1900.

Cuzebio Paulo de Oliveira: Relatorio sobre a geologia . . da Expedição Roosevelt-Rondon. Jornal do Commercio. Rio de Janeiro, Novembro 15, 1914.

Euzebio Paulo de Oliveira: Expedição Scientifica Roosevelt-Rondon. Annexo I, Geologia, 79 paginas. Rio de Janeiro, 1915.

G. ReinoenL: Terreno minero cerca de Coxim. Matto Grosso. Buenos Aires (d. ?), 45 paginas.

H. H. Smith : O planalto de Matto Grosso. Revista de Engenharia 28 de Janeiro de 1885, volume VII, paginas 17-18.

H. H. Smrth : Do Rio de Janeiro a Cuyabá. Rio de Janeiro, 1886.

K. von Den Sternen : Erforshung des Xingu: Durch Zentral Brasilien. Leipzig, 1886.

L. VoN AMMoN: Devonische Versteinerungen von Lagoinha in Matto Grosso. Zeitschrift der Gesellschaft für Erdkunde zu Berlin, volume XXVIII, pages 352-366. Berlin, 1893.

Dr. P. Voger: Reisen in Matto Grosso, 1887-88. (Zweite Schingú-Expedition) mit Anhang: Devonische Versteinerungen von Lagoinha in Matto Grosso. Zeitschrift der Gesellschaft für Erdkunde zu Berlin, volume XXVIII, pages 309-366. Berlin, 1893.

\section{MINAS GERAES}

Previous investigations.-The geographic details of the base map of Minas Geraes are taken chiefly from the Mappa do Estado de Minas by Benedicto José dos Santos, published in 1910.

It is somewhat remarkable that though Minas Geraes is the great mining state of Brazil, and though a vast amount has been written about it, its geology is probably less clearly understood than that of any state in that country. One reason for this is that the attention of the world has been directed to its mining rather than to its geology.

The establishment by the imperial government of the national "Escola de Minas" at Ouro Preto in 1875 and the opening of that school October 12,1876 , was a step of the greatest importance, not only for engineering education in Brazil, but also for the advancement of the science of geology in the state and throughout the whole country. Some of Brazil's ablest statesman and, with but few exceptions, all of her geologists and mining engineers have been educated at this school. It is maintained by the federal government and is now under the ministry of Agriculture, Indus- 
try, and Commerce. The director from $18^{7} 75$ to 1891 was Dr: Henri Gorceix; the present director, who succeeded Dr. Gorceix in 1891, is Dr. $J$ J. C. Costa Sena, a native of Minas Geraes and a graduate of the school. In this connection should be mentioned the establishment of the "Annaes da Escola de Minas," in which have appeared many valuable contributions to the geology and mineralogy of Brazil by the professors and students of the school. Fourteen numbers or volumes have been issued.

The state began a geological and topographical survey in 1892, under the title of Commissão Geographica e Geologica de Minas Geraes. Work was carried on until October, 1898, when it was suspended. ${ }^{72}$ The following ten topographic sheets were published by this survey on a scale of 1 to 100,000, with 50-meter contours: Ayuruoca, Baependy, Barbacena, Carrancas, Ibertioga, Lavras, Lima Duarte, Luminarias, Rio Preto, and São João d'el Rei. Besides these topographic sheets the commissão published reports of progress which appeared in the form of five bulletins between 1892 and 1898. A geological sheet was prepared for publication in 1899 , but before it could be issued the survey was suspended.

On the geology proper the following writers are noteworthy: Eschwege, Gorceix, Helmreichen, Pissis, Leith, Harder, and Chamberlin. In addition to the reports of progress of the Commissão Geographica e Geologica, valuable geologic notes made on trips through the state are those of M. A. R. Lisboa, Francisco de Paula Oliveira, J. C. da Costa Sena, Antonio Olyntho, and 0. A. Derby.

Special mention should be made of the work done by Horace E. Williams, of the Serviço Geologico do Brazil, in northwestern Minas between south latitude $18^{\circ} 30^{\prime}$ and $21^{\circ}$, and between west longitude $45^{\circ}$ and $48^{\circ}$. The results of Mr. Williams' excellent work on this area have been sent me, but unfortunately they reached me too late to be incorporated in the map.

General geology.-Archean rocks cover a larger area in the state of Minas than any other one division of the geologic column. They are exposed over nearly all of the southern and eastern parts of the state, occupying an area of 266,600 square kilometers out of a total state area of about 580,000 square kilometers. Included in this Archean area, however, is the old Paleozoic series mentioned in the following paragraph.

Thrust-faulted into the Archean are certain old metamorphosed Paleozoic rocks that now appear as quartzites, schists, itacolumites, marbles, and as iron and manganese ores. These infaulted areas are often small

72 The following were directors at afferent periods :

Augusto de Abreu Lacerda, 1892 to 1895.

Alvaro da Silveira, 1895 to 1898. 
and unimportant isolated masses, but again they are hundreds of kilometers in length, while in area they cover thousands of square kilometers. On account of lack of knowledge of the details of their distribution, many of the smaller areas are included in the area of the Archean rocks given in the preceding paragraph. As a rule, they form belts or zones and they frequently appear as parallel ridges or mountain ranges. The rocks thus infaulted are generally metamorphosed, and, as they are more resistant than the surrounding granites and gneisses, they usually form the prominent features in the topography of the region.

The age of these old sediments is not known, and they are therefore represented on the map simply as early Paleozoic. They are probably older than the Carboniferous. Their structural relations to the Archean rocks are well shown in the accompanying section from the paper by Harder and Chamberlin, page 368.

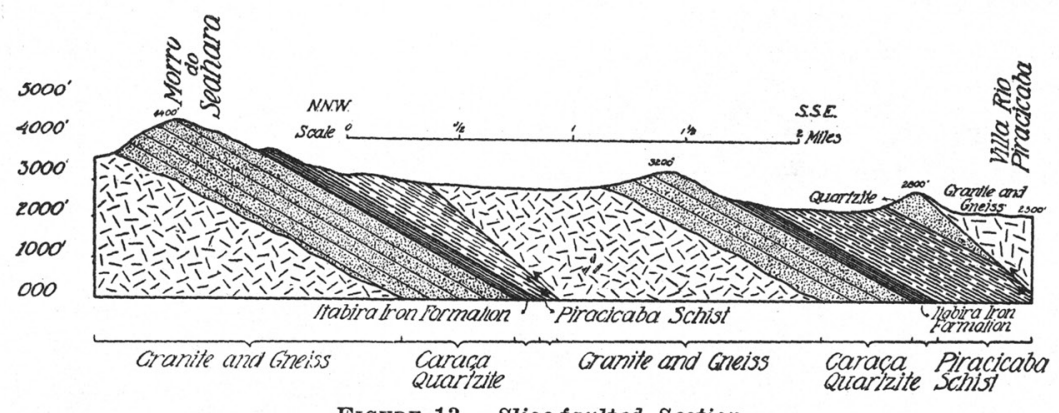

Figure 13.-Slice-faulted section

This section is between Villa Rio Piracicaba and Morro do Seahara.-Harder and Chamberlin.

The next newer rocks are probably a series of sandstones or quartzites corresponding to and continuous with the diamond-bearing quartzites of the State of Bahia. These rocks are exposed at Grão Mogol, in the north of Minas, where they are diamond-bearing just as they are in Bahia, and like those in Bahia they are referred provisionally to the Carboniferous.

The structural relations of these quartzites are fairly well shown in the section published by Helmreichen in 1846, and by Gorceix in 1884 .

Rocks of this series are probably exposed at many places about the edges of the Permian and even inside of it. They can not be clearly discriminated with our present knowledge, for much confusion has been caused by the use of the word "itacolumite" for sandstones and quartzites of many kinds and of several different geologic horizons.

In view of all the data available, it seems probable that the diamonds of Minas Geraes have come directly from these Carboniferous quartzites, 
just as they do in Bahia, and that they occur in the Permian where they have been redeposited, and that outside of existing Carboniferous and Permian areas they occur where the older beds have been removed during long periods of denudation.

The next higher beds are the Lower Permian sediments, whose contact with the Archean enters the southern end of the State from São Paulo just north of the city of Jacuhý, and runs northward and eastward past Formiga, Pitanguy, Santa Luzia, west of Diamantina, east of Montes Claros, Monte Alto, in Bahia, and seems to end east of the Rio São Francisco at a point about thirty kilometers south of Bom Jesus da Lapa. The Lower Permian has not hitherto been recognized as such in the State of Minas Geraes, and the reference of certain beds to that horizon is based partly on the character of the rocks and partly on their tying up with the known Lower Permian of the State of São Paulo. The position of the base of the series as shown on the map has been gathered from miscellaneous notes on the geology of the region, and can not therefore be accepted as anything more than an attempt to locate the margin of the series believed to be Lower Permian. The question of the Permian as a whole and the evidence bearing on it is discussed under the head of "Permian," at page 38.

The rocks of the series are shales, sandstones, limestones, and conglomerates that have been but little affected by folding or faulting. In Minas these beds form extensive tablelands and are deeply trenched by the streams. There seems to be strong presumptive evidence of glacial deposits at the base of the series at several places, but it requires confirmation, so far as Minas is concerned.

The large area of limestone in the valley of the Rio São Francisco in the north end of the state and north of the conflueice of the São Francisco and the Rio das Velhas has not been studied. It is assumed that these limestones are of the same age as those east of the river, namely, Permian. See discussion under Permian.

There are a few small lake deposits in the state of Tertiary age. The best known are those at Gandarella and at Fonseca, which have been described by Gorceix. ${ }^{73}$

The Gandarella basin is northwest of Ouro Preto, about half way between Conceição and Santo Antonio. The rocks are clays, gravels, sands, and lignites. One bed of lignite is a meter in thickness.

The Fonseca basin is northeast of Ouro Preto, near the village of that name and close to Rio Piracicaba, east of the town of Agua Quente. The

73 H. Gorcelx : Bacias terclarias d'agua doce. Annaes da Escola de Minas no. 3, pp. 95-114. Rlo, 1884. 
deposits are horizontal beds laid down in a basin of Archean rocks. They consist of beds in the following order from the top:

Meters

1. Canga, or iron conglomerate. $\ldots \ldots \ldots \ldots \ldots \ldots \ldots \ldots \ldots \ldots \ldots \ldots \ldots \ldots$

2. Fossiliferous clay shales........................ 5

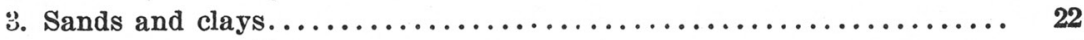

4. Bituminous shales...........................

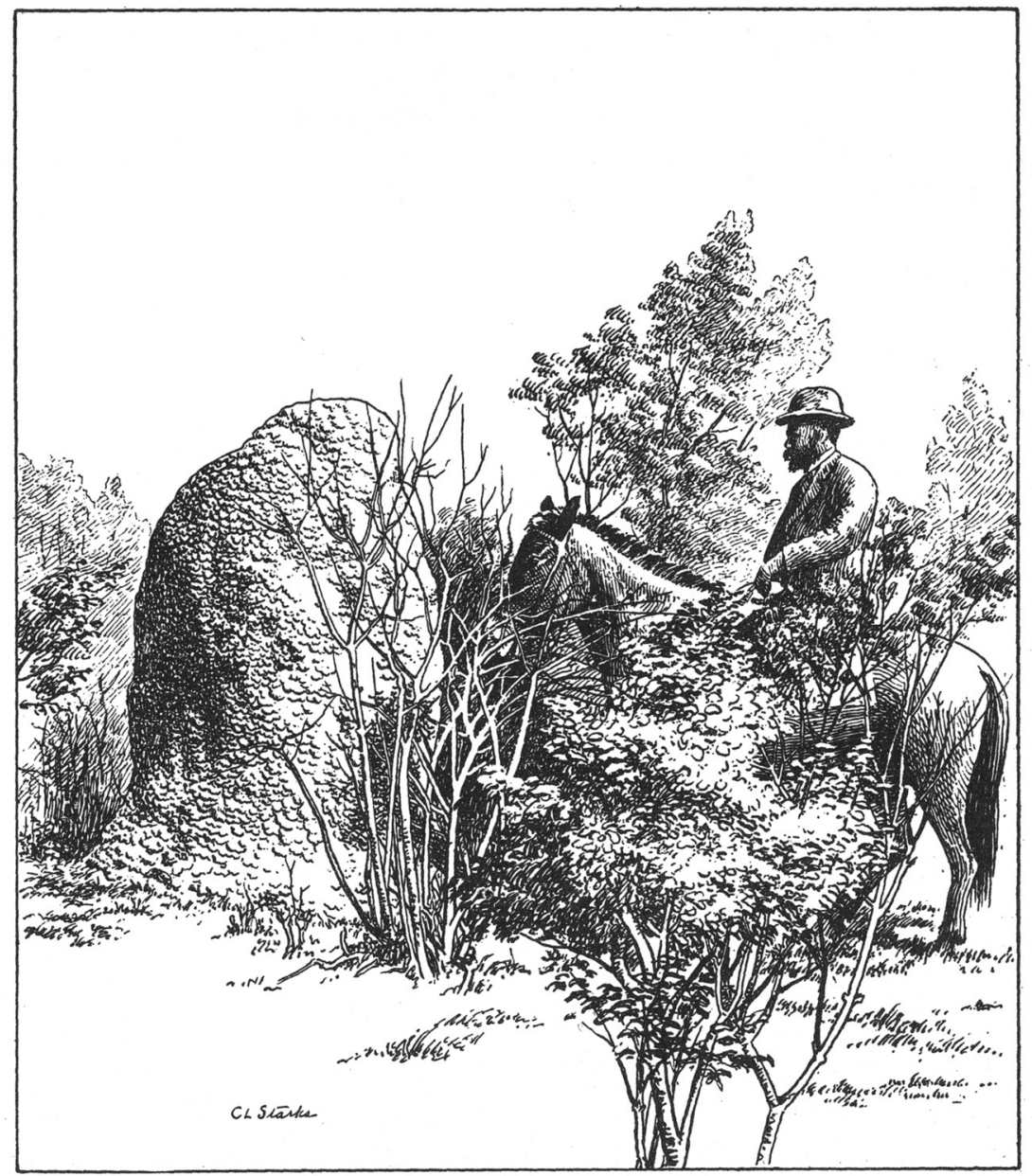

FIGURE 14.-Above-ground Structure of White Ants

View taken seven kilometers west of Queluz, State of Minas Geraes.

The remarkable cave deposits of Minas Geraes and their Pleistocene fossils have been collected and studied by Peter Lund, a Danish natural- 
ist, who spent forty-seven years (1833-1880) in his Brazilian explorations. His materials were described by various specialists, notably by Hansen, Lütken, Quatrefages, Reinhardt, Warming, and Winge.

The hard cones of earth built over the surface of the ground by termites ("white ants") in many parts of the interior are impressive and are probably of some geologic importance. The true ants also make extensive underground galleries.

Economic geology.-Minas Geraes is the chief mining State of Brazil. ${ }^{74}$ It has an unusually large number of minerals of economic importance, though only gold, manganese, iron, and diamonds have ever been extensively worked. It was in Minas that gold was first discovered in Brazil, about 1693, and the earliest mining done in that country was for gold in what is now that state. For some years Brazil was the leading goldproducing country of the world. Though there have been and still are a few notable rock mines in the old Paleozoic series where the gold originated, most of the gold of Brazil has come from placer deposits. Among the many writers on the gold deposits of Minas whose papers are worthy of especial attention are Claussen, Eschwege, Ferrand, and Ferraz.

The discovery of diamonds in Minas became known about 1724,* and from a few years after that until the discovery of the diamond mines of South Africa, Minas was the leading diamond-producing region of the world. The diamonds have come chiefly from the placer deposits, though many stones have been found in situ, especially about Grão Mogol. The ciamonds are not so widely distributed as gold. Something about the theories of the origin and distribution of diamonds will be found under the head of "diamonds," at page 234. The following authors have written on the diamond deposits of Minas: Galogeras, Campos, Claussen, Derby, Eschwege, Gorceix, Mawe, Hussak, Heusser and Claraz, and Oliveira.

The manganese deposits of Minas first attracted attention in 1893, and in $1894,1,430$ tons of the ore were exported, ${ }^{75}$ and since 1896 that state has been one of the great manganese-producing regions of the world.

\footnotetext{
"For references to the mining laws of Brazil and of Minas Geraes, see "Mining laws," at page 16 et seq.

* The discovery of diamonds was claimed to have been made in 1723 or 1724 by Bernardo da Fonseca Lobo, and his claim was recognized by the crown of Portugal February 26, 1734 (Revista do Archivo Publico Mineíro, Anno II, fasc. 2, pp. 271-273. Ouro Preto, 1897). As a reward "The King, our Lord . . . sees fit to bestow upon him the post of chief captain of the Villa do Principe [now called Serro] during his llfetime, residence of the same every triennium, the office of notary of the Villa do Principe, and one hundred milrels pension money for his two sisters, Marla Nunes Machado and Margarida Nunes Machado. . . . from which each of them shall cede twelve milreis to the persons they are to marry that they may receive the habits of the Order of Christ which he will have bestowed upon them at Occidental Lisbon April 12, 1734."

T5 Herbert K. Scott: The manganese ores of Brazil. Journal of the Iron and Steel Institute, vol. lvii, p. 189 . London, 1900.
} 
The ores occur at two horizons, namely, in the Archean complex and in the early Paleozoic series of rocks. The mines worked are in the vicinity of Lafayette, in the Archean, and at Miguel Burnier, on the Central Railway, in the Paleozoic. Later discoveries have been made on the properties of the Saint John del Rey Mining Company at Capitão do

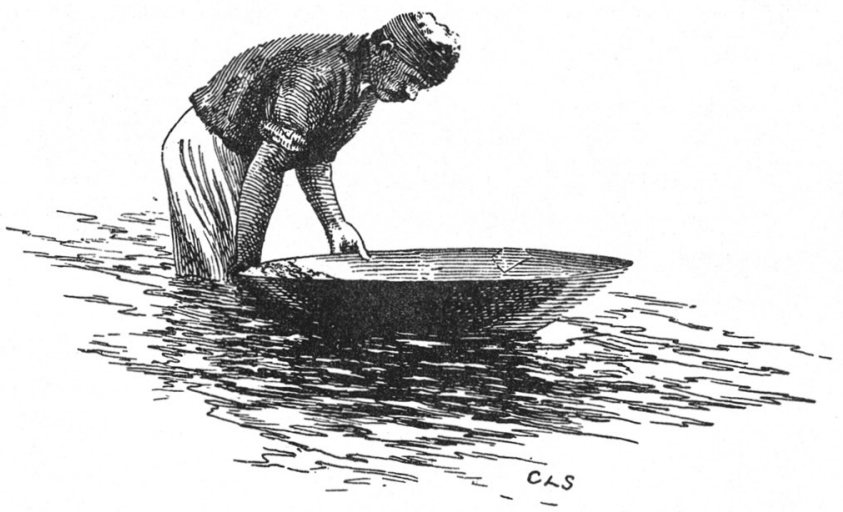

Figure 15.-Brazilian method of Diamond washing with the wooden Batea

Matto and Cachoeirinha near Morro Velho. Valuable papers on the manganese deposits of Minas are by Derby, Greven, Lisboa, Lustosa, Michaeli, Scott, Singewald, and Thomas.

The iron deposits of Minas have long been known, but only within a few years have they attracted the attention to which they are justly entitled. They are probably the most important iron ores known, though they are as yet but little used. A paper by Dr. Francisco de Paula Oli-

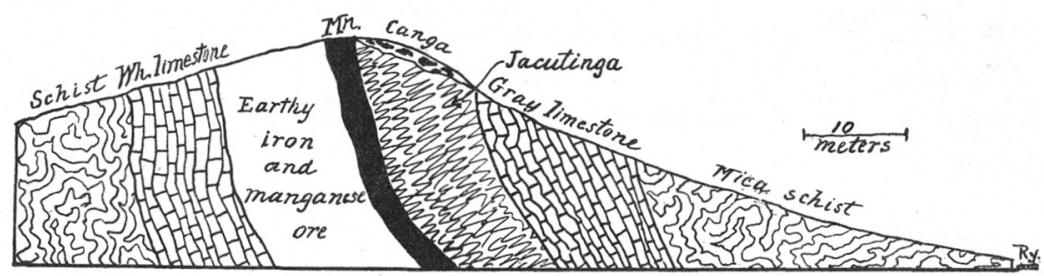

FIgURE 16.-Section at the Miguel Burnier Manganese Mines

This section is at kilometer 501 of the Central Railway. After Scott.

veira, published in the Annaes da Escola de Minas, number 3, pages 135194, tells of the efforts to make iron in the state. The iron ores are in sedimentary rocks, either in and forming parts of the early Paleozoic rocks or they are later deposits derived therefrom. The most important papers on the geology of the ores are those of Chamberlin, Berby, Dupré, 
Eschwege, Ferrand, Graça, Gorceix, Harder, Leith, Lisboa, and Scott. Derby points out, however, in his paper on "The iron ores of Brazil," published in "The iron-ore resources of the world" (Stockholm, 1910, page 817), that the work on the Minas iron ores reported in his paper was done almost exclusively by Dr. Gonzaga de Campos.

Many other minerals are known, but as yet they are not developed. Among these the following appear to be the more important:

Nickel has been found in the Archean area of southern Minas. The deposits are described by H. E. Williams, of the Serviço Geologico do Brasil, the title of whose paper is given below.

Platinum has long been known to occur in connection with the auriferous iron sands of the old Gongo Soco mines and in the alluvial diamond deposits. No effort has been made to recover it.

Marbles and limestones are found in great abundance, but, aside from their local use for the manufacture of lime, they are undeveloped. The marbles are mostly from the Archean regions. Especially attractive varieties of marble are reported from Gandarella. ${ }^{78}$ Amorphous limestones are abundant in the Permian regions, in the upper part of the Valley of Rio das Velhas, and in the northern part of the state, near the Rio São Francisco. At Paineiras, near Uberaba, limestone is quarried in what are supposed to be Cretaceous rocks.

Asbestos is reported from the vicinity of Santa Luzia.

Talc is abundant in the Brazilian complex associated with metamorphic rocks.

Mica is known at Bicas, Fonseca, Manhuassú, Santa Luzia, and it is to be looked for in pegmatite dikes anywhere within the Archean area of the state.

Niter deposits are found in the limestone caves of the state.

Graphite is found in veins in the Archean rocks in the vicinity of Minas Novas and at São Miguel. The deposits are described by Dr. J. C. da Costa Sena.7

Extensive deposits of bauxite have been found by Dr. George Chalmers at Motúca on the property of the Saint John del Rey Mining Company near Villa Nova de Lima.*

Phenacites are found at Piracicaba.

The mineral waters of Minas are among the important economic geologic products of the state. The thermal waters of Poço de Caldas are

${ }^{76} \mathrm{~F}$. de Paula Oliveira : Revista Industrial de Minas, vol. iv, p. 275, 30 de Março de 1897.

77 Annaes da Escola de Minas, vol. 11, pp. 125-129. Rlo de Janeiro, 1886.

* Eighty-eighth Ann. Rept. of the directors of the Saint John del Rey Mining Company, London, June, 1919, pp. 59-60. 
worthy of special attention. The waters of Caxambú and Limbarý are well and favorably known in the Brazilian market.

Besides those noted by Gorceix in the Tertiary basins, bituminous shales are said to occur in the Serra de Sete Lagoas.*

A valuable book in connection with the history of mining in the State of Minas is the Historia do Districto Diamantino, by Dr. Joaquim Felicio dos Santos, published at Rio de Janeiro in 1868. Those who visit. the region will be interested to read Mawe's Travels, first published at London in 1812, and at Philadelphia and Boston in 1816. Mawe was an English mineralogist and was the first foreigner permitted to visit the diamond regions of Brazil.

The climate of Minas Geraes is remarkably fine and healthful; the region is high and well watered and in many places well timbered.

\section{Geologic Maps of Minas Geraes}

Pissis, 1842.-In 1842 the French Academy of Science published A. Pissis' "Mémoire sur la position géologique des terraines de la partie australe du Brésil," etcetera, and that paper was accompanied by what is called a geologic sketch-map (Esquisse géognostique) of the gold region of Minas Geraes. It embraces an area of something more than 9,400 square kilometers, from 10 kilometers south of Ouro Branco to Cocaes on the north. The map is on a scale of 1 to 250,000 and four geologic divisions are shown, namely: gneiss, talc, quartzite, itabirite, and limestone.

That same paper contains another geological map that embraces the region from Bahia on the north to Piracicaba, São Paulo, on the south, and all of the province of Minas Geraes east of Rio São Francisco. The scale of this map is 1 to 2,500,000 and the following geologic divisions are shown: four for the "terrain primitif"; two for the "periode phylladienne"; one for diorite; two for the Tertiary.

Harder and Chamberlin, 1915.-The small map published by Harder and Chamberlin in connection with their article on the geology of central Minas Geraes, in the Journal of Geology, May-June, July-August, volume XXIII, page 341, etcetera, shows the general geology of the region extending from Queluz to Diamantina and about one degree wide. The scale is about 1 to $22,000,000$ and seven geologic divisions are shown.

\section{Bibliography of the Geology of Minas Geraes}

A. DE Bover: A Industria mineral na Provincia de Minas Geraes. 1a parte, ouro e ferro. Annaes da Escola de Minas de Ouro Preto, 1883, No. 2,

E. Liais : Climats, Géologie, etc., du Brésil, Paris, 1872, p. 130. 
paginas 25-99. Revista de Engenharia, 28 de Fevereiro de 1884, volume VI, paginas 44-42; 14 de Março de 1884, volume VI, paginas 50; 28 de Março, volume VI, paginas $65-66 ; 14$ de Abril de 1884, volume VI, paginas 75-76; 28 de Abril de 1884, volume VI, paginas 91-92; 14 de Maio de 1884, volume VI, paginas 101-102; 14 de Junho de 1884, volume VI, paginas $128 ; 28$ de Junho de 1884, volume VI, paginas $138-139 ; 28$ de Julho de 1884, volume VI, paginas 158-160; 14 de Agosto de 1884, volume VI, paginas 172-173; 14 de Setembro de 1884, volume VI, paginas 189-191; 28 de Setembro de 1884, volume VI, paginas 204-205; 14 de Outubro de 1884, volume VI, paginas $216-217$; 28 de Outubro de 1884, volume VI, paginas $227-229$; 14 de Novembro de 1884, volume VI, paginas 241-242. Rio de Janeiro, 1884 .

A. DE BoveT: LIndustrie Minérale dans la Province de Minas-Geraes. Annales de Mines, 8a série, volume III, pages 85-122, 123-208. Paris, 1883.

A. DE BovET: Gold in the province of Minas Geraes, Brazil. Engineering and Mining Journal. New York, October 20, 1883.

A. DE Bover : Diamond mining in the Province of Minas Geraes, Brazil, volume I. Engineering and Mining Journal, October 6, 1883. Volume II, October 13, 1883. New York, 1883.

A. DE Bover: L'exploitation du diamant au Brésil. La Nature, volume XII, année 1884 (2me série), pages 166-170, illustrated. Paris, 1884.

A. DE BoveT: Notes sur une exploitation de diamants près de Diamantina, Province de Minas Geraes, Brésil. Annales des Mines, 8me série, volume V, pages 465-504. Paris, 1884.

J. C. Branner: Geologic work of ants in tropical America. Bulletin of the Geological Society of America, volume 21, August, 1910, pages 449-496.

Dr. Hermann Burmeister: Reise nach Brasilien, durch die Provinzen von Rio de Janeiro und Minas Geraes. Mit besonderer Rücksicht auf die Naturgeschichte der Gold und Diamantendistricte. Berlin, 1853.

Captain RICHARD F. BURTON : Explorations of the highlands of Brazil, with a full account of the gold and diamond mines; also, canoeing down 1,500 miles of the great River São Francisco from Sabara to the sea. Two volumes, $8^{\circ}$. London, 1869.

J. P. Calogeras: Gisements diamantifères d'Agua Suja. Revista Industrial de Minas Geraes. Anno II, 15 de Janeiro de 1895, paginas 5-8; 15 de Fevereiro de 1895, paginas 33-37.

Albert T. CaLvert : Mineral resources of Minas Geraes. $8^{\circ}$, illustrated. London, 1915. (A compilation full of typographic errors; the photographs are good; the maps are not acknowledged.)

L. F. Gonzaga de Campos: Jazidas Diamantiferas de Agua Suja, Bagagem, Estado de Minas Geraes. Rio de Janieiro, Companhia Editora Eluminense, 1891. 52 paginas, with two maps.

GoNZaga de GaMpos: Informações sobre a industria siderurgica. Boletim do Ministerio da Agricultura, Anno V, paginas 29-66. Rio de Janeiro, 1916.

Francis Castelnau et Eugene d'Osery: Expédition dans les parties centrales de l'Amérique du Sud . . . pendant les années 1843 a 1847. . . . Quatrième partie. Paris, 1852.

R. T. Ghamberlin and E. C. HARDer: The geology of central Minas Geraes, Brazil. Journal of Geology, volume XXIII, pages 341-378, 385-424. Chicago, 1915. 
P. Claussen: Notes géologiques sur la province de Minas Geraes au Brésil. Bulletin de l'Academie Royale de Bruxelles, volume VIII, number 5, pages 322-344, four plates, one geologic map. Bruxelles, 1841.

H. H. C. DA Costa: Artigos publicados nos annexos do Relatorio pelo Secretario de Estado dos Negocios das Finanças (do Estado de Minas Geraes). Bello Horizonte, 1905.

o. A. Derby: Geology of the diamond. American Journal of Science, third series, volume XXIII (CXXIII), pages 97-99. New Haven, February, 1882. Also, in The Rio News, volume IX, March 15, 1882, page 3. Rio de Janeiro, 1882.

O. A. Derby : On the gold-bearing rocks of the Province of Minas Geraes. Brazil. American Journal of Science, third series, volume XXIII (CXXIII), page 178. New Haven, March, 1882.

O. A. Derbr: Modes of occurrence of the diamond in Brazil. American Journal of Science, third series, volume XXIV (CXXIV), pages 34-42. New Haven, July, 1882.

O. A. DeRBY : Relatorio . . a acerca dos estudos geologicos practicados nos valles do Rio das Velhas e alto São Francisco, Rio de Janeiro, Typographia Nacional, 1882, paginas 38.

O. A. DeRBy : Nephelene-bearing rocks in Brazil. Abstract : Proceedings of the American Association for the Advancement of Science, 1890, volume XXXIX, page 263. Salem, 1891.

O. A. Derby: Notes on certain schists of the gold and diamond regions of eastern Minas Geraes, Brazil. American Journal of Science, volume $\mathbf{X}$, pages 207-216. New Haven, 1900.

o. A. Derby : On the manganese ore deposits of the Queluz (Lafayette) District, Minas Geraes, Brazil. American Journal of Science, volume XII, pages 18-32. New Haven, July, 1901.

Leandro Dupré, Junior: Estudo geologico e mineralogico da região E. de Ouro Preto, comprehendida entre aquella cidade a povoação do Taquaral e o Rio do Carmo. Archivos do Museu Nacional do Rio de Janeiro, volume III, paginas 11-16. Rio de Janeiro, 1878.

BARON D'Esch WEGE: Idées génerales sur la constitution géologique du Brésil. Annales des Mines, 2me série, Tome II, pages 238-240. (Paris) 1817.

W. I. von EschWEGE: Journal von Brasilien oder vermischte Nachrichten aus Brasilien, auf wissenschaftlichen Reisen gesammel. Two volumes. Weimar, 1818.

W. L. voN EsOHWEgE: Beiträge zur Gebirgskunde Brasiliens. $x v+488$ pages. Berlin, 1832.

EschWege: Bosquejo geognostico do Brasil, com huma dissertação sobre a matriz dos diamantes. $2^{\circ}$ Additamento a "Geologia Elementar" de Nereo Boubée, 2a parte, paginas 35-39. Rio de Janeiro, 1846.

W. L. voN Esch WEge: Pluto Brastliensis. Fine Reihe von Abhaldlungen über Brasiliens Gold-Diamanten und anderen mineralischen Reichthum, etc. $8^{\circ}$, xviii +622 pages. Berlin, 1833.

Dr. Paulo Ferrand: Industria de ferro no Brazil. Provincia de Minas Geraes. Revista de Engenharia, 14 de Setembro de 1883, volume V, paginas 237239. Rio de Janeiro, 1883. 
Padl Ferrand: A Industria de ferro no Brazil. Annaes da Escola de Minas de Ouro Preto, 1885, No. 4, paginas 167-188. Rio de Janeiro, 1885.

Paur Frrrand : Ouro Preto et les mines d'or (B́résil). Le Génie Civil; Revue génerale hebdomadaire des Industries françaises et étrangéres. (Illustrated.) Tome XVI, XVII, XIX, XX, XXIII, 1890 to 1893. Paris, 18901893.

Paul Ferrand : Exploitations auriféres de Minas Geraes. Revista Industrial de Minas Geraes. Anno, I. Ouro Preto, 15 de Outubro de 1898, paginas 6-11. Ouro Preto, 1893.

Paur Frrrand : L'or a Minas Geraes, Brésil. E'tude publiée par les soins de la commission de l'Exposition preparatoire de l'wtat de Minas Geraes a Ouro Preto, á l'occasion de l'exposition miniére et métallurique à Santiago, Chile, em 1894. Ouro Preto, 1894. Two volumes. It is also published in Portuguese in the Revista de Fngenharia, as far as page 60 of volume I of the original French edition, under the title Ouro Preto e as minas de ouro. Rio de Janeiro, 1887-1891.

Paul Ferrand : Industria do ferro, seu estado actual no Brazil. Revista Industrial de Minas (reraes. Anno I, No. 5, 15 de Fevereiro de 1894, paginas 102-106. Ouro Preto, 1894.

Luiz Ferraz: The Palma gold-deposit, Minas. Brazilian Mining Review, volume I, pages 173-174. Rio de Janeiro, February, 1904.

F. FreIse: Die Monazitseifen im Grenzgebiete der brasilienischen Staaten Minas Geraes und Espirito Santo Speziell im Gebiete des Muriahé und Pomba-Flusses. Zeitschrift für Praktische Geologie, volume XVII, pages 514-522, 1909; and Zeitschrift für Berg-Hütt.-und Salinenw, volume LVII, pages $47-64,1910$.

Th. GathmanN: Beitrag zur Kenntniss der "Itabirit Fisenerze in Minas Geraes, Brasilien, volume XXI, Mai, pages 234-240. Berlin, 1913.

GEORGe Gardner: Travels in the interior of Brazil, principally through the northern provinces and the gold and diamond districts, during the years 1836-1841. $8^{\circ}$, xvi +562 pages, map. Iondon, 1846. Second edition, xviii +428 pages, map and plate. $8^{\circ}$. London, 1849 . It contains valuable notes on the geology of the interior of Ceara, Piauby, and Minas Geraes.

Henrique Gerber: Geographical notes on the province of Minas Geraes. Journal of the Royal Geographical Society, volume XLII, pages 262-300. London, 1874.

HENRIQUE GERBER: Noções geographicas e administrativas da Provincia de Minas Geraes por Henrique Gerber, engenheiro da mesma Provincia. Reimpressão da 1a edição de 1863. Hannover, 1874, Geologia, paginas 17-20; mineração, paginas 31-34.

hentique Carlos de Magalhães Gomes: (Fxploração geologica a oeste da Mantiqueira), paginas 18-29 of Annexo A. do Relatorio apresentodo ao Dr. Secretario de Estado da Agricultura do Estado de Minas Geraes pelo Inspector de Terras e Colonização, Dr. Carlos Prates em 1897. Ouro Preto, 1897.

H. GoBceix : Les explorations de l'or dans la province de Minas Geraes, Brésil. Bulletin Sociêté Géographique, 6me série, volume XII, pages 530-543. Paris, 1876. 
H. GoRCEIX : Note sur la roche connue vulgairement au Brésil sous le nom de Canga, et sur le bassin d'eau douce de Fonseca (Province de Minas Geraes).. Bulletin Société Géologique de France, 3me série, volume IV, pages 321-323. Paris, 1876.

Gorcerx: Sur divers mineraux du Brésil. (Extrait d'une lettre.) Bulletin Sociêté Géologique de France, 3me série, volume IV, page 522. Paris, 1876.

H. GorceiX : Mina de carvão de pedra em Minas Geraes. Officio dirigido ao Presidente da Provincia. Auxiliador da Industria Nacional, No. 7, Julho de 1878, volume XLVI, paginas 164-165. Rio de Janeiro, 1878.

H. GoRckix : Estudos geologicos e mineralogicos sobre algumas localidades da Provincia de Minas Geraes pelos alumnos engenheiros da Escola de Minas de Ouro Preto. Archivos do Museu Nacional do Rio de Janeiro, volume III, paginas 9-10. Rio de Janeiro, 1878.

H. Gorcerx: Sur la martite du Brésil. (Extrat d'une lettre a M. Delesse.) Comptes Rendus de l'Academie des Sciences, volume XC, pages 316-318. Paris, 1880. Abstract: Neues Jarbuch für Mineral, 1881, volume I, page 13. (Referate.)

Gorceix: Sur les schistes cristallins du Brésil et les terres ronges qui les recouvrent. (Extrait de lettres a M. Delesse.) Comptes Rendus de l'Academie des Sciences, volume XCI, pages 1099-1101. Paris, 1880.

Gorcerx: Sur le gisement du diamant au Brésil. (Extrait d'une lettre a $M$. Delesse.) Bulletin Société Minéralogique de France, volume III, pages 3638. Paris, 1880.

Henrique Gorceix : O ferro e os mestres de forja na Provincia de Minas Geraes. $8^{\circ}, 16$ pages. Ouro Preto, 1880 . Idem. $4^{\circ}, 24$ paginas. Rio de Janeiro, 1880.

Henrique Gorceix: The iron industry of Minas Geraes. The Rio News, volume VII, number 24, August 24, 1880 ; volume VII, number 25, September 5 , 1880. Rio de Janeiro, 1880.

Henrique 'Gorceix: Geology of the Province of Minas Geraes. Abstract of two articles in the Annaes da Escola de Minas de Ouro Preto. The Rio News, volume VIII, number 15. Rio de Janeiro, May 24, 1881.

H. GorceIx : Brazilian diamonds and their origin. Popular Science Monthly, volume XXI, pages 610-620. New York, 1882.

Gorcetx: Sur les gisements diamantifères de Minas Geraes, Brésil. Comptes Rendus de l'Academie des Sciences, volume XCIII, pages 981-983. Paris, 1881. Bulletin Société Minéralogique de France, volume $\nabla$, pages 9-13. Paris, 1882.

GorCEIX : Nouveau Mémoire sur le gisement du diamant a Grão Mogor, Province de Minas Geraes, Brésil. Comptes Renđus de l'Academie des Sciences, volume XCVIII, pages 1010-1011. Paris, 1884.

TorceIX : Gisement de diamants de Grão Mogor, Province de Minas Geraes, Brêsil. Bulletin Société Géologique de France, 3me série, volume XII, pages 538-545. Paris, 1884.

H. Gorceix : Bacias terciarias d'agua doce nos arredores de Ouro Preto (Gandarela e Fonseca), Minas Geraes, Brazil. Annaes da Escola de Minas de Ouro Preto, No. 3, paginas 95-114. Rio de Janeiro, 1884.

GoRcErx, H.: Noticia sobre os cascalhos diamantiferos. Annaes da Escola de Minas de Ouro Preto, No. 3, paginas 195-207. Contendo os dois artigos 
seguintes: Noticia relativa a alguns mineraes dos cascalhos diamantiferos contendo acido phosphorico, alumina e outras terras da familia do cerium, paginas 197-202. Noticia relativa a um zeolitho de uma rocha pyroxenica da bacia do Abaeté, Minas Geraes, paginas 205-207. Rio de Janeiro, 1884.

W. HAIDINGER: Ueber den durchsichtigen Andalusit von Minas Novas in Brasilien. Abhandlungen der k. böhm. Gesellschaft der Wissenschaften, V. Folge, Band 3, pages 33-40. Separate. Prag, Gottlieb Hasse Sohne, 1844.

W. HAIDINGER: Vorworte zu "Ueber das Geognostische Vorkommen der Diamanten und ihre Gewinnungsmethoden auf der Serra do Grão-Mogor in der Provinz Minas Geraes in Brasilien, von Virgil von Helmreichen." Wien, 1846.

H. G. F. HALFELD: Atlas e relatorio concernente a exploração do Rio de Sĩo Francisco desde a Cachoeira da Pirapóra até o Oceano Atlantico. Levantado por ordem do governo de S. M. Dom Pedro II, 1852-1854. Illustrated, 57 paginas, folio, 36 maps. Rio de Janeiro, 1860. Notice: Petermann's Mittheilungen, 1866, paginas $412-414$.

Soren Hansen : La race de Lagôa Santa. L'homme fossile de Pontimelo, in E museo Lundii. En Samling af Afhandlingar om de $i$ det indre Brasiliens Kalkstenshuler af Prof. P. W. Lund udgravede Dyre-og Menneskeknogler. Kjobenhavn, H. Hagerups Boghandel, volume I, pages 35-37, 18881896.

E. C. HARder: The "Itabirite" iron ore of Brazil. Economic Geology, March, 1914, volume IX, pages 101-111.

E. C. Harder and R. T. Chamberdin : Geology of central Minas Geraes, Brazil. Journal of Geology, volume XXIII, pages 341-378, 385-424. Chicago, 1915.

E. C. HARDER: Notes on certain iron-ore resources. Brazil. Bulletin of the American Institute of Mining Engineers, number 141, pages 1471-1475. New York, September, 1918.

Virgil von Hexmreichen: Reisebericht aus Minas Geraes vom 6 Mai, 1846, Berichte uber d. Mittheilungen von Freunden d. Naturwissenschaft in Wien. Vienna, 1847, volume II, pages 137-151.

Virgil von HeLmReichen: Ueber das geonostische Vorkommen der Diamanten und ihre Gewinnungs-Methoden auf der Serra do Grão Mogor. Vorworte w. Haidinger. Wien, 1846.

Ch. Heusser et G. Craraz: Gisement et exploitation du diamant dans la Province Minas Geraes au Brésil. Extract p. M. Delesse from Ueber die wahre Lagerstätte der Diamanten $u$. anderer Edelsteine in der Provinz Minas Geraes in Brasilien, von Ch. Heusser u. G. Claraz in Zeitschrift der Deutschen geologischen Gesellschaft, volume Xr, pages 448-466. (Bemerkungen zur vorstehenden Abhandlungen von G. Rose, ibidem, page 467.) Annales des Mines, 5e série, volume XVII, pages 289-299. Paris, 1860.

C. Hlawatsch : Der Raspit von Sumidouro, Minas Geraes (Brasilien). Centralblatt für Mineralogie, Geologie und Paleontologie, number 14, pages 422-427. Stuttgart, 1905.

Ales HrduIckA : Early man in South America. Bulletin 52, Bureau of American Ethnology. Washington, 1912. (Brazil, pages 153-184.)

Hussak: Sobre o deposito diamantifero de Agua Suja, perto de Bagagem, Minas Geraes. Relatorio parcial da Commissão exploradora' do Planalto Central do Brazil, pelo Dr. Luiz Cruls, paginas 105-128. Rio de Janeiro, 1893. 
Dr. Eugenio Hussak: Sobre a occurrencia de cinabrio em Tripuhy, Minas Geraes. Revista Industrial de Minas Geraes: Anno IV, No. 23, 20 de Abril de 1897, paginas 291-293. Ouro Preto, 1897.

E. Hussak : Der goldführende, kiesige Quarzlagergang von Passagem in Minas Geraes, Brasilien. Zeitschrift für praktische Geologie, Oktober, 1898, pages 345-357, figures. Berlin, 1898. Abstract: Transactions of the American Institute of Mining Engineers, 1900, volume XXX, pages 626-642, illustrated. New York, 1901.

E. Hussak: Ueber die Diamantlager im Westen des Staats Minas Geraes . . . Zeitschrift für praktische Geologie, volume XIV, Oktober, 1906, pages 318333.

E. Hussak : Sobre a raspita do Sumidouro, Este de Minas Geraes. Annaes da Escola de Minas, No. 6, pages 99-103. Ouro Preto, 1903.

E. Hussak : Os satellites do diamante. Traduzido e publicado por Jorge B. de Araujo Ferraz. Royal $8^{\circ}, 56$ pages. (Bibliography.) Rio de Janeiro, 1917.

A. DE A. LACERdA: Relatorio da Commissão geographica e geologica do Estado de Minas Geraes. Annexo 3 do Relatorio apresentado ao Dr. Presidente do Estado de Minas Geraes pelo Secretario de. Estado dos Negocios da Agricultura, Commercio e Obras Publicas, Dr. Francisco Sa em o anno de 1895. II. Annexo 3, paginas 1-35, e Sub-annexo A, B, C, D, E, F (Topographia, etc.). Ouro Preto, 1895.

C. K. LEITH and E. C. HARDER: Hematite ores of Brazil and a comparison with hematite ores of Lake Superior. Economic Geology, volume VI, OctoberNovember, 1911, pages 670-686.

Alberto B. Paes leme: A Euxenita do Pomba e as condições geologicas de sua jazida. $8^{\circ}, 20$ pages. Rio de Janeiro, 1915.

Eмm. Liars : Explorations scientifiques au Brésil. Hydrographie du haut San Francisco et du Rio das Velhas. Paris, 1865, in-fol. 26 pages et planches.

M. A. R. Lisboa : Occorrencia de seixos facetados no planalto central do Brasil. Ann. da Escola de Minas, No. 8, paginas 23-74. Ouro Preto, 1906.

M. A. R. Lisboa : Report on the manganese ore deposits of Morro da Mina, Lafayette Queluz, Minas Geraes, Brazil. Brazilian Engineering and Mining Review, volume III, pages 83-88, 97-111. Rio, June and July, 1906.

Miguel Ribeiro Lisboa: Les Manganeses du Brésil. Revue Universelle des Mines, de la Métallurgie des travaux publics, des sciences et des arts, appliquées a l'industrie. 42e Année, 3me série, Tome XLIV, 4e Trimestre, 1-22. Paris, Liege, 1898.

M. Arrojado Ribeiro Lisboa: O manganez no Brazil. Separate, 48 paginas. Rio de Janeiro, 1898. Jornal do Commercio do Rio de Janeiro, 19 de Junho de 1898.

Arrojado Ribeiro Lisboa: Le manganése du Brésil. Annales des Mines, 9me série, Tome VI, pages 115-116. $8^{\circ}$. Paris, 1899.

Iours Lombard: A mineração nos municiplos de São João d'El-Rey, Tiradentes e Prados no Estado de Minas Geraes. Revista Industrial de Minas Geraes, 15 de Julho de 1894, paginas 243-246. Ouro Preto, 1894. Mineração da Serra de São José. Revista Industrial de Minas Geraes, 15 de Agosto de 1894, paginas 271-275. Ouro Preto, 1894. 
ToHN Luccock: Notes on Rio de Janeiro and the southern parts of Brazil; taken during a residence of ten years in that country, from 1808 to 1818 . $4^{\circ}$, maps, xvi +639 pages. London, 1820.

L.UND: Nouvelles observations sur la faune fossile du Brésil. Extraites d'une lettre adressée aux rédacteurs. Annales des Sciences Naturelles, 2me série, volume XII, Zoologie, pages 205-208. Paris, 1839. Abstract: Neues Jahrbuch fuir Mineralogie, 1840, pages 740-741.

P. W. LUND: On the occurrence of fossil human bones of the prehistorical world. American Journal of Science, volume XLIV, pages 277-280. New Haven, 1843.

LUND: Sur l'antiqueté de la race americaine [etc.]. Comptes Rendus de l'Academie des Sciences, volume XX, pages 1368-1370. Paris, 1845.

P. W. LUND: Notice sur des ossements humains fossiles, trouvés dans une caverne du Brésil. Mémoires de la Société Royale des Antiquaires du Nord, pages 49-77. Copenhague, 1845-1847.

Pedro W. Lund: Cavernas existentes no calcareo do interior do Brazil, contendo algumas dellas ossadas fosseis. 1a memoria. Copenhague, 1836. Annaes da Escola de Minas de Ouro Preto, No. 3, paginas 61-92. Rio de Janeiro, 1884.

Chr. Lütren: Résumé des remarques préliminaires de M. Lïtken sur les ossements humains des cavernes du Brésil et des collections de M. Lund E Museo Lundii. Volume 1, pages 19-29. Kjöbenhavn, 1888. (Remains of animals and of men, excavated by Professor Lund in the limestone caves of Minas.)

Jordano Machado: Beitrag zur Petrographie der südwestlichen Grenze zwischen Minas Geraes und S. Paulo Inaugural-Dissertation, verfasst und der hohen philosophischen Facultät der Grossherzoglichen Herzoglichen Gesammt-Universität Jena. $8^{\circ}, 43$ pages. Wien, 1887. Tschermak's Mineralogie und Petrographie Mittheilungen. N. F. 1887, volume IX, pages 318360. Wien, 1888.

R. J. DA C. Matros: Itinerario do Rio de Janeiro ao Pará e Maranhão pelas provincias de Minas Geraes e Goiaz. Two volumes. Rio de Janeiro, 1836.

JoHN MAwE: Travels in the interior of Brazil, particularly in the gold and diamond districts of that country. $8^{\circ}, 374$ pages. Boston, 1816; first edition, London, 1812.

Alcides Medrado: Mines and minerals in the States of Minas Geraes and Bahia, Brazil. Monthly Bulletin of the Bureau of American Republics, volume XII, pages 100-134. Washington, 1902.

ALCIDEs Medrado: Historical sketch of gold mining in Minas Geraes, Brazil. Engineering and Mining Journal, March 29, 1902, volume LXXIII, page 447 ; also, in Brazilian Mining Review, volume I, pages 21-22, 23-33. Ouro Preto, 1902.

Joaquim G. Michaeli : The manganese deposits of Gandarella, Minas Geraes, Brazil. Engineering and Mining Journal, December 21, 1901, volume LXXII, page 818. New York, 1901.

Cropomira A. DE Oliveira: Metallurgia do ferro em Minas Geraes. Annaes da Escola de Minas, No. 5, pages 55-112; No. 6, pages 10-81. Ouro Preto, 1902-1903. 
F. DE P. OLIVEIRA : Noticia sobre as jazidas mineraes do Gandarella. Revista Industrial de Minas Geraes. Anno IV, No. 22, 30 de Março de 1897, paginas 275-276. Ouro Preto, 1897.

Francisco de Paula Oliveira: Itinerario geologico de Ouro Preto ao Rio Abaeté. Auxiliador da Industria Nacional, No. 11, Novembro de 1879, volume XLVII, paginas 245-251. Rio de Janeiro, 1879.

Francisco de Paula Oliveira: Exploração das minas de galena do Ribeirão do Chumbo, affuente de Abaeté e estudo da zona percorrida de Ouro Preto até esse logar. Annaes da Escola de Minas de Ouro Preto, No. 1, 1881, paginas 35-94. Rio de Janeiro, Typographia Nacional, 1881.

Francisco de Paula Or.rveira: Jazida de cinabrio das Tres Cruzes perto de Tripuhy. Revista Industrial de Minas Geraes. Anno I, No. 7, 15 de Abril de 1894, paginas 159-161. Ouro Preto, 1894.

F. De Paula Ouveira: Noticia sobre os terrenos diamantinos da região dos rios São Antonio, Somno e Abaeté. A Industria, anno 1, No. 4, 30 paginas. Rio de Janeiro, Junho-Dezembro, 1912.

Hugh Pearson: The gold field of Paracatú, Minas Geraes, Brazil. Transactions of the Institute of Mining Engineers, 1906, volume XXXI, pages 257-263.

Antonio OLyntho dos Santos Pires: Viagem aos terrenos diamantiferos do Abaeté. Annaes da Escola de Minas de Ouro Preto, No. 4, paginas 93-164. Rio de Janeiro, 1885.

Dr. Antonio Olyntho dos Santos Ptres: The manganese deposits of Bahia and Minas, Brazil. Transactions of the American Institute of Mining Engineers, pages 9-10 of separate, volume XXIX, pages 764-765. New York, 1899.

A. PIssis : Mémoire sur la position géologique des terrains de la partie australe du Brésil et sur les soulèvements qui, à diverses époques, ont changé le relief de cette contrée. Comptes Rendus de l'Academie des Sciences, volume XIV, pages 1044-1046. Paris, 1842, 60 pages. Same title. Mémoires de Institute de France, Tome X, pages 353-413, two geological maps, three plates of sections, one chart.

Jон. Ем. Ронц : Beyträge zur Gebirgskunde Braziliens, nebst Aufzählung aller aingesammelten, und im k. k. Brazilianer Museum in Wien, aufbewahrten, einfachen und zusammengesetzten Fossilien. Von Dr. John Em. Pohl. Besonderer Abdruck aus dessen Reise im Innern von Brasilien. Erste Abtheilung mit einer lithographirten, geognostischen Ansicht. $4^{\circ}, 64$ pages, I geological section. Wien, 1832.

H. Poroheron: Rapport sur les mines de diamants de Agua Suja, dans l'tetat de Minas Geraes, Brésil, 1903.

Carlos Prates e arthur Guimarães: Empresa de mineração do Caethé. Revista Industrial de Minas Geraes, No. 1, pagina 20. Ouro Preto, 15 de Outubro de 1893.

Carlos Prates: Jazida aurifera de Marzagão. Revista Industrial de Minas Geraes, Anno I, No. 4, paginas 77-80. Ouro Preto, 15 de Janeiro de 1894.

DE QUaTrefages: L'homme fossile de Lagoa-Santa (Brésil) et ses descendants actuels. (Extract from les actes du Congrès Anthropologique de Moscou, 1879.) Comptes Rendus de l'Academie des Sciences, 1881, volume XCIII, pages 882-884. Separate, $4^{\circ}, 19$ pages. Paris, 1881. 
Carlos Nunes Rabello: Serra de Treituba, Minas Geraes. Revista Industrial de Minas Geraes. Anno V, No. 20, paginas 57-58. Ouro Preto, 30 de Outubro, 1897.

Carlos N. Rabello: Relatorio dos trabalhos durante a campanha de 1895, paginas 127-130. Ouro Preto, 1896. Annexo A : Relatorio da Commissão Geographica e Geologica.

Carlos N. RABELLo: Relatorio apresentado ao engenheiro chefe da Commissão Geographico e Geologica de Minas . . . em 1898. Bello Horizonte, 1898. (Geologia, paginas 123-129.)

Cartos N. Rabello: A Serra de São Thomé das Lettras. Annuario da Escola Polytechnica de São Paulo. Anno. IV, paginas 59-62. São Paulo, 1903.

Theonoro Sampaio: O Rio de São Francisco. Trechos de um diario de viagem. São Paulo, 1905.

H. K. ScotT: The manganese ores of Brazil. Journal of Iron and Steel Institute, volume LVII, pages 179-208. London, 1900.

H. K. ScotT: The iron ores of Brazil. Journal of Iron and Steel Institute, pages 237-257. London, 1902.

J. C. DA Costa Sena: Viagem de estudos metallurgicos no centro da provincia de Minas Geraes. Annaes da Escola de Minas de Ouro Preto, No. 1, paginas 95-128. Rio de Janeiro, 1881.

J. C. Da Costa Sena: Noticia sobre a mineralogia e geologia de uma parte do Norte e Nordeste da Provincia de Minas Geraes. Annaes da Escola de Minas de Ouro Preto, 1883. No. 2, paginas 111-131.

Joaquim Candido da Costa Sena: Exposição Mineralogica e Metallurgica de Santiago do Chile. Annexo No. 7 do Relatorio Apresentado ao Dr. Presidente do Estado de Minas Geraes . . . em o anno de 1895, volume II, Annexos 43 paginas. Ouro Preto, 1895. (Contains notes on Brazilian minerals, ores, and rocks.)

Joaquim Candido da Costa Sena: Minas de Ouro do Cybrão, Municipio de Marianna. Revista Industrial de Minas-Geraes. Anno IV, No. 22, pagina 276. Ouro Preto, 1897.

J. C. Da Costa Sena: Mineração dos arredores de Ouro Preto. Revista Industrial de Minas Geraes. Anno V, No. 34, pagina 143. Ouro Preto, 1897.

Costa Sena: Mineral resources of the State of Minas Geraes, Brazil. Translated from the Portuguese by Dr. Alcides Medrado. Mining and Metallurgy, volume XXIV, December 15, 1901, pages 703-705. New York, 1901.

J. C. Da C. Sena: Minerios de ferro no Brasil, principalmente no Estado de Minas. Considerações geraes sobre a industria do ferro. Annaes da Escola de Minas de Ouro Preto, No. 10, 1908, paginas 19-34. Ouro Preto (n. d.).

Dr. José Frañkin da Silva: Panorama do Sul de Minas. Revista Instituto Historico, volume XLV, part II, paginas 405-435. Rio de Janeiro, 1882. (On physical features, geology, and natural history.)

alvaro Astolpho da Silveira: Relatorio do Geologo da Commissão Geographica e Geologica de Minas durante o anno de 1894, paginas 23-34 do Annexo No. 3, sub-annexo F. do Relatorio apresentado ao Dr. Presidente do Estado de Minas Geraes pelo Secretario de Estado dos Negocios da Agricultura, Commercio e Obras Publicas Dr. Francisco Sá em o anno de 1895, volume II. Ouro Preto, 1895. 
ALfaro Smveira: Analyse No. 3. Calcareo da pedreira da Capoeira Grande a um kilometro de Barroso. Revista Industrial de Minas-Geraes, Anno I, No. 9, 15 de Junho de 1894, pagina 232. Ouro Preto, 1894.

alvaro Astolpho da Sillveira: Engenheiro Chefe. Relatorio da commissão geographica e geologica. Annexo ao Relatorio apresentado ao Dr. Secretario de Estado da Agricultura do Estado de Minas-Geraes pelo Inspector de Terras e Colonização em 1897. Annexo A, pages 1-19. Ouro Preto, 1897.

SPIX und Martius: Reise in Brasilien, volume I, page 287; volume II, page 558. Münich, 1823, 1828.

KIRBY THомAs: (Brazil as a source of manganese ore.) Bulletin 129, American Institute of Mining Engineers, volumes XIII-XVI. New York, September, 1917.

J. J. von Tsch Udr : Die Brasilianische Provinz Minas Geraes. Petermann's Mittheilungen, 42 pages, $4^{\circ}$. Gotha, 1862.

Eugen Warming: Ein Aufzug nach Brasiliens Bergen, Die Natur., Neue Folge, volume VII, pages 156-159, 170-172, 194-196, 208-209. Halle, 1881.

Eugen Warming: Lagoa Santa. Et Bidrag til den biologiske Plantegeografi. Avec résumé en française. 336 pages. Kjöbenhavn, 1892.

Horace E. Williams: Notas sobre . . . occorrencia de nickel perto de Livramento . . . Minas Geraes. Bol.' do Ministerio da Agricultura, Anno V, No. 1, paginas 21-28. Rio de Janeiro, 1916.

HerLuF WINGe: Marsupiaux fossiles et vivants de Lagoa Santa, Minas Geraes, Brésil. E Museu Lundii. En Sanling af Afhandlingar om de 1 det indre Brasiliens Kalkstenshuler af Prof. Lund udgravede Dyre - og mennesheknogler. Volume II, pages 134-149. Kjöbenhavn, 1888-1896.

H. Winge: Singes (Primatés) fossiles et vivantes de Lagoa Santa, Minas Geraes, Brésil. E Museu Lundii, volume II, paper V, pages 47-57. Kjöbenhavn, 1895-6.

H. Winge: Carnivores fossiles et vivantes de Lagoa Santa, Minas Geraes, Brésil. E Museu Lundii. Kjöbenhavn. 1895-6.

\section{PARA}

Previous investigations.-A good résumé of the geology of Pará is given by Katzer in his Grundzüge der Geologie des unteren Amazonasgebietes, Leipzig, 1903. I have followed his map in the main, but with modifications on certain points. The distribution of the various formations on the southern side of the Amazon, as shown on Katzer's map, is especially uncertain. The Carboniferous has been certainly recognized south of the Amazon in the State of Pará only on the Tapajos; the Silurian, Devonian, and Cretaceous have not been certainly recognized in Pará on the south side of the Amazon at all. The ages of the rocks of areas so represented must therefore be considered as yet in doubt. The area shown as Carboniferous or Permian about the confluence of Rios Araguaya and Tocantins I have shown as Permian, because it thus fits on to the known Permian of Maranhão without doing violence to Katzer's views. The occurrence of Devonian beds on the Araguaya is very doubt- 
ful, and the Cretaceous probably does not reach that river on the west. I have purposely omitted Katzer's distribution of eruptive rocks in the State of Pará. Data for such a map are not available in any part of Brazil. Katzer's geologic map of Pará should only be used in connection with the text which it accompanies. ${ }^{78}$ The best original papers on the geology of Pará are those of Derby, Hartt, Smith, and Katzer. The fossils are described by Clarke, Derby, and Rathbun. The geology along the Oyapok and on the boundary with French Guiana is outlined in Velain's description of the rocks collected there by Crevaux. The outlines of the floodplain of the Amazon between 54 degrees and 56 degrees are taken from Herbert $H$. Smith's map in his "Brazil, the Amazon and the Coast."

General geology.-The Amazon River follows a synclinal trough across the State of Pará. The northern and southern parts of the State are Archean, against which are deposited Silurian rocks on the north and Devonian and Carboniferous on both the north and south sides. From western Pará the Paleozoic sedimentary beds extend into the State of Amazonas, but they are not certainly known east of the Tapajos, on the south side of the Amazon, or east of Rio Maecurú, on the north side, though it seems reasonable to suppose that they do extend farther east on both sides. Rocks of later, but of uncertain, age are found at many places through the middle of the valley. Following the coast north and south of the mouth of the Amazon are horizontal sedimentary beds probably of Tertiary age. Fossils found at Pirábas and at other points on the coast east of Salinas show that some of these beds are certainly Eocene, as Miss Maury has pointed out. (See bibliography.)

Economic geology.-Gold is found in the Archean area along the streams that flow directly into the ocean from the Guiana highlands. Limestones occur in the Carboniferous beds at Itaituba, and are reported in the mountains of the southeastern part of the state. Very little is known as yet. however, of the geology of the southern part of ths State of Pará, and the economic geology is therefore necessarily unknown and undeveloped.

\section{Geologic Maps of Pará}

Ch. Velain, 1885.-In 1885 M. Ch. Velain published in the Bulletin de la Société Géographique de France a paper on the geology of French Guiana, "Esquisse géologique de la Guyane française," using the data collected by Dr. J. Crevaux in his explorations. The article is accompa-

${ }^{78}$ F. Katzer : Grundzilge der Geologie des unteren Amazonas-gebletes. Lelpzig, 1903. 
nied by a geologic map that embraces nearly all of northeastern Pará from Obidos to the mouth of the Amazon. It is on a scale of 1 to 6,000 ,000 and shows ten lithologic subdivisions.

Katzer, 1903.-In his Grundzüge der Geologie des unteren Amazonasgebietes, Dr. F. Katzer gives a geologic map of the State of Pará on a scale of 1 to $4,400,000$. Many subdivisions of the eruptive rocks are given; of the sedimentary beds he makes eight divisions, including the alluvial deposits.

\section{Bibliography of the Geology of Pará *}

Prince Adalbert of Prussia: Travels of His Royal Highness Prince Adalbert of Prussia in the south of Europe and in Brazil, with a voyage up the Amazon and the Xingu. Translated by Sir Robert $H$. Schomburgk and John Edward Taylor. Two volumes, $8^{\circ}$. Volume I, 338 pages; volume II, 337 pages. London, 1849. (The Brazilian portion begins in volume I, page 211, and extends to the end of volume II.) It contains notes on the character of the rocks.

Professor and Mrs. Lours Agassiz: A journey in Brazil. xix +540 pages, illustrated. Boston: Ticknor \& Fields, 1868. Chapter XIII, Physical history of the Amazons, pages 397-441, and many geological notes.

J. C. Branner: The pororóco, or bore, of the Amazon. Science, November, 1884, volume IV, pages 488-492, illustrated ; also, separate, with additional notes. Illustrated, 12 pages, $8^{\circ}$. Boston, 1885.

Grorges Brousseau : Les Richesses de la Guyane Française et de l'ancien contesté Franco-Brésilien. Onze ans d'exploration. Illustrated and map, 248 pages, VIII. Paris, Société d'éditions scientifiques, 1901. 4me partie, ancien contesté franco, brésilien, page 185 et seq. Constitution géologique générale, page 193 et seq. L'or, etc., pages 217-234. Houille, pages 235-236.

Chardes B. Brown and J. G. Sawkins : Reports on the physical, descriptive, and economic geology of British Guiana. Published by order of the Lords Commissioners of Her Majesty's Treasury. London, 1875. (297 pages, illustrated, and maps.) Geology on the Brazilian frontier.

W. Chandless: Notes on the rivers Arinos, Juruema, and Tapajos. Journal of the Royal Geographical Society, volume XXXII, pages 268-280. London, 1862.

John M. Clarke: As trilobitas do grez de Freré e Maecurú, Estado do Pará, Brazil. Archivos do Museu Nacional do Rio de Janeiro, volume IX, paginas 1-58, 2 plates, 2 figures. Portuguese and English. Rio de Janeiro, 1896.

John M. Clarke: A fauna siluriana superior do Rio Trombetas, Estado do Pará, Brazil. Archivos Museu Nacional Rio de Janeiro, volume $\mathbf{X}$, pages 1-48, 1 figure. (Portuguese and English.) Rio de Janeiro, 1899.

John M. Clarke: Molluscos devónianos do Estado do Pará, Brazil. Archivos Museu Nacional Rio de Janeiro, volume $X$, paginas $49-174,8$ plates, $4^{\circ}$. (Portuguese and English.) Rio de Janeiro, 1899.

* Many of the references to Amazonas contain notes on Pará also. 
John M. Clakke: The Paleozoic faunas of Pará, Brazil. 1. The Silurian Fauna of the Rio Trombetas. 2, The Devonian Mollusca of the State of Para. Author's English edition. Albany (N. Y.), 1900.

Dr. Oтто liauss: Bericht uber die Schingú-Expedition im Jahre 1884. Petermann's Mittheilungen aus Justus Perthes' Geographischer Anstalt, 32 Band, 1886, pages 129-134. Gotha, 1886.

Paul le Colnte: Le bas Amazone. Annales de Géographie 61, 12e année, pages 54-66. Paris, 1903. (Geography, page 59.)

Henry G. Dalton: The history of British Guiana, . . . together with an account of its climate, geology, staple products and natural history. In two volumes $\left(8^{\circ}\right)$. London, 1855. Volume I, introductory chapter, pages 1-58, on physical features and geology.

O. A. Derby : On the Carboniferous Brachiopoda of Itaitúba, Rio Tapajos, Province of Pará, Brazil. Bulletin of Cornell University (Science), volume I, number 2, pages 1-63, plates i-ix. Ithaca, N. Y., 1874.

O. A. DeRBY : A contribution to the geology of the lower Amazonas. Proceedings of the American Philosophical Society, volume XVIII, pages 155-178. Philadelphia, 1880.

o. A. Derby : The Amazonian Upper Carboniferous fauna. Journal of Geology, volume II, number 5, pages 480-501. Chicago, 1894.

O. A. Derby : Trabalhos restantes ineditos da Commissão Geologica do Brazil 1875-1878. Boletim do Museu Paraense, volume II. Pará, 1897-8.

I. A ilha de Marajo, volume II, number 2, pages 163-173.

IV. Reconhecimento do Rio Mãecurú, volume II, number 2, pages 192204.

VI. A Serra de Maxira, volume II, number 3, pages 340-343.

VII. A Serra de Tajuri, volume II, number 3, pages 344-351.

$X$. O Rio Trombetas, volume II, number 3, pages 366-382.

I. EuTrope: Guyane française. Carte géographique-géologique, dessiné d'apres les reconnaissances et observations faites de 1867 à 1878 par le bureau du cadastre de Cayenne. Echelle 1:400,000. Paris, 1879.

Francisco José de Freitas : Noticia geologica da região situada entre Paracary e o Maecurú. Revista de Engenharia, Fevereiro 15, 1880, volume II, pages 10-11. Rio de Janeiro, 1880. Also, separate, 16me, 15 paginas. Rio de Janeiro, 1880.

Crr. Fred. HARTt : Geology and physical geography of Brazil. Boston, 1870. (Pará, pages 484-495.)

CH. FRed. HARTT: Report of a reconnaissance of the Lower Tapajos. Bulletin of Cornell University (Science), volume I, numbers 1 and 2, pages 11-37, illustrated. Ithaca, N. Y., 1874.

Crr. Fred. Hartt: Geological discoveries in Brazil. (Extract from letter.) American Naturalist, volume V, pages 342-343. Salem, 1870.

Ch. Fred. HartT: Devonian rocks in the Amazonian Valley. American Naturalist, volume $V$, pages 121-122. Salem, 1871.

Ch. Fred. HartT: Recent explorations in the valley of the Amazonas. With map. Transactions of the American Geographical Society of New York (volume III), pages 231-252. Albany, 1872.

CH. FRED. HARTT: Contributions to the geology and physical geography of the lower Amazonas. Bulletin of the Buffalo Society of Natural Science, volume I, pages 201-235. Buffalo, 1874. 
Ch. Fred. Harte : A geologia do Para. Reprint of a report written for the editor of the Diario do Grão Para in 1870, at Para, Brazil. Published in the Boletim do Museu Paraense, volume I, number 3, June, 1896, pages 257-273, with footnote by Dr. E. A. Goeldi. Para, 1896.

CH. Fr. HARTT : Trabalhos restantes ineditos da Commissão Geologica do Brazil (1875-1878). Introducção, paginas 155-163. Volume II, A região de Breves, paginas 173-181; III, o Rio Tocantins, paginas 181-191. Boletim do Museu Paraense, volume II, No. 2. Para, 1897. Volume V, Monte Alegre e Ereré, paginas 322-340; volume VIII, A Serra de Paranaquára, paginas 352-358. Boletim do Museu Paraense, volume II, No. 3. Pará, 1898.

.5. Huber et von Kraatz-Koschxau : Entre l'Océan et le Rio Guamá. Bulletin Société Géographique, Tome III, pages 123-132. Paris, 1901.

Friedrich Kamzer: As camadas fossiliferas mais antigas da região Amazonica. Boletim do Museu Paraense, volume I, paginas 436-438. Paræ, 1896.

FrIEDRICH KATZER: Beitrag sur Kenntniss des älteren Palaeozoicums im Amazonasgebiete. Sitzungsberichte der Kgl. böhm. Gesellschaft der Wissenschaften. math. nat. Classe, Nr. XXIX, 1896, pages 23-25. Prag, 1896.

Dr. FrIedrich KaTZer: Der strittige Golddistrict von Brasilianisch-Guyana. Oesterreichische Zeitschrift für Berg-und Hüttenwesen, 29 Mai,.1897, volume $\mathrm{XLV}$, pages 295-300. Wien, 1897.

Dr. Frederico KATZER: Relatorio resumido sobre os resultados geologicos praticos da viagem de exploração ao Rio Tapajos e a região de Monte Alegre, . . . Boletim do Museu Paraense, volume III, paginas 134-165. Para, 1901.

Frtedrich KatZer: Grundzüge der Geologie des unteren Amazonas Gebietes. 301 pages, $8^{\circ}$. Leipzig, 1904.

Garlotta Joaquina Maurx: A contribution to the paleontology of Trinidad. Journal of the Academy of Natural Sciences of Philadelphia, volume XV, pages 32-33. Philadelphia, 1912.

H. Meewarth : Eine geologische Forschungreise nach dem Rio Acará im Staate Para. Globus, volume 86, pages 289, 309. Braunschweig, 1904.

RICHARD RathBun : On the Devonian Brachiopoda of Ereré, Province of Pará, Brazil. Bulletin of the Buffalo Society of Natural Sciences, volume I, pages 236-261. Buffalo, 1874.

GharLes SchucherT: Geology of the lower Amazon region. Journal of Geology, volume XIV, pages 722-746. Chicago, 1906.

HerberT H. Smith: Geology and physical geography of the Amazons Valley. Appendix to "Brazil, the Amazons, and the coast," pages 619-635. New York, 1879.

Dra. Emmia Snethlage: A travessia entre o Xingú e o Tapajos. Boletim Museu Goeldi, volume VII, paginas 49-92. Pará, 1913.

SpIx und Martius: Reise in Brasilien. Volume III, pages 887-1054. Munich, 1831.

CH. VtuatN : Notes géologiques sur Haute-Guyane, d'apres les explorations du Dr. Crevaux. Bulletin Sociêté Géologique de France, 3me série, part I, 1879 , volume VII, pages $388-395$; part II, 1881, volume IX, pages $396-417$.

GH. Vtuatn : Esquisse géologique de la Guyane Française, etc. Bulletin de la Sociêté Géographique, $7 \mathrm{me}$ série, volume VI, pages 453-492. Paris, 1885.

XX-BULl. GeoL. Soc. AM., VoL. 30, 1918 


\section{PARAHYBA}

Previous investigations. -The geography of the State of Parahyba is taken from the maps of the Inspectoria de Obras Contra as Seccas, made under the direction of Dr. M. Arrojado R. Lisboa.

The papers of Branner, Crandall, Soper, and Williamson contain nearly all that is known of the geology of the State of Parahyba. There are a few valuable notes made by Agassiz at Parahyba and by Burlamaqui in the interior. The geologic map of this state is chiefly from the personal observations of the author.

General geology.-The Brazilian complex covers all of the State of Parahyba except a belt, about forty kilometers wide, along the seacoast, and an infolded area, probably Cretaceous, of about twelve hundred square kilometers at and west of Souza, on its western frontier. The Archean rocks are cut by basic intrusives. There are some isolated patches of Mesozoic or Cenozoic deposits in the mountain tops near and west of Teixeira-remnants of beds that have been removed by denudation. The rocks of the Brazilian complex in Parahyba are mostly highly inclined (50 to 75 degrees) crystalline schists, gneisses, and granites cut by quartz veins in which gold has been mined. Williamson, cited in the bibliography, gives a section, opposite page 116, six miles long, in the Valley of Rio Bruscus.

Along the coast is a belt of Cretaceous and Tertiary sediments that nowhere exceed a width of 50 kilometers. The Cretaceous rocks are mostly impure marly limestones that are exposed in the quarry at the city of Parahyba and along the railway between Parahyba and Cabedello. These limestones contain fossils, cephalopods, fish remains, and crustacea that indicate their Cretaceous age. Careful search has not been made at other places, but it is quite probable that these Cretaceous beds extend both north and south of Parahyba, though they do not appear on the open coast. Owing to poor exposures, it is not possible to give the thickness of the Cretaceous in Parahyba; the total thickness visible is only about twenty meters, but neither the top nor the bottom of the series was seen.

Overlying the Cretaceous are the horizontal particolored Tertiary beds that form the vertical bluffs of Cabo Branco and elsewhere along this part of the coast.

Economic geology.-Gold was formerly mined from the quartz veins in the Archean area near Piancó, but the mines have long been abandoned and no mines are now operated in the state.

It is claimed that there is much iron in Parahyba, but there is no 
trustworthy information available in regard to its location, quality, or quantity.

Limestone is quarried from the Cretaceous beds at the city of Parahyba, and there has been talk of the utilization of that rock for the manufacture of Portland cement, but no serious attempts have been made at such manufacture.

Marble is found at various places within the Archean area, and it is said that it has been used locally for the manufacture of lime, but otherwise it is undeveloped.

\section{Geologic Maps of Parahyba}

Branner, 1902.-A geologic map of the eastern end of the state is given in Branner's paper on the "Geology of the Northeast Coast of Brazil," as plate 4 of volume 13 of the Bulletin of the Geological Society of America, 1902. It shows the approximate extent of the Cretaceous and Tertiary sediments in that State.

R. H. Soper, 1913.-Publication number 26 of the Inspectoria de Obras Contra as Seccas, entitled "Geologia, etc., do Rio Grande de Norte e Parahyba," by Ralph H. Soper, contains a sketch-map of the geology of Parahyba on a scale of 1 to $1,000,000$ and with four subdivisions of the geology, namely: (1) gneisses, schists, and granites, (2) sandstones, (3) limestones, (4) sands and clays.

\section{Bibliography of the Geology of Parahyba}

J. C. Branner: Geology of the northeast coast of Brazil. Bulletin of the Geological Society of America, volume 13, pages 41-98. Rochester, 1902.

Dr. Frederico Leopoldo Cesar Burlamaqur: Noticia acerca dos animaes de raças extinctas, descobertos em varios pontos do Brazil. Dated Rio, 9 de Junho de 1855. Bibliotheca Guanabarense. Trabalhos da Sociedade Vellosiana, 1855, paginas 19-20, 2a parte. Rio de Janeiro, 1855(?).

F. L. C. BURLAm Provincias do Brasil, recebidos no Museu Nacional durante o anno de $\mathbf{1 8 5 5}$ (dated September, 1856). Revista Brazileira, volume II, paginas 73-104. Rio de Janeiro, 1858.

Roderic Grandall: Geographia, geologia . . . nos estados orientaes do norte do Brazil, Ceara, Rio Grande do Norte e Parahyba. Publication No. 4, series I. D. E. Inspectoria de Obras Contra as Seccas. Rio de Janeiro, 1910.

I. JofriLY: Notas sobre a Parahyba. Geology, paginas 63-88. Rio de Janeiro, 1892.

HeNRY Koster: Travels in Brazil. Second edition, in two volumes. London, 1817. A few notes on the geology, pages 64-85. 
Mary J. Rathbun: Description of a new species of Zainthopsis from Parahyba do Norte. Bulletin of the Geological Society of America, volume 13, pages 43-44, illustrated. Rochester, 1902.

W. REAY, JR. : Mining explorations in Brazil. The provinces of Parahyba and Pernambuco. The Mining Journal, February 13,.1864, volume XXXIV, page 106. London, 1864.

RALPH H. SoPER : Geologia e supprimento d'agua subterranea no Rio Grande do Norte e Parahyba. Publicação 26 da Inspectoria de Obras Contra as Seccas. 62 paginas. Rio de Janeiro, 1913.

R. H. SOPER: The geology of Parahyba and Rio Grande do Norte, Brazil. Proceedings of the American Philosophical Society, volume LV, pages 1-20. Philadelphia, 1916.

E. Williamson: Geology of Parahyba and Pernambuco gold regions. Transactions of the Manchester Geological Society, volume VI, pages 113-122. Sessions of 1886-7. Manchester, 1868.

S. W. WILLIston : Description of a new species of Cimolichthys from Parahyba do Norte. Bulletin of the Geological Society of America, volume 13, pages 44-45, illustrated. Rochester, 1902.

\section{PARANA}

Previous investigations.-The most important papers on the geology of Paraná are those of Derby, Oliveira, Siemiradzki, White, and Woodworth, while the report of Clarke on the Devonian fossils is the most important on the paleontology. Of these the late report of Dr. Euzebio Paulo de Oliveira is the most comprehensive, and brings our knowledge of the geology of that state up to date. By an unfortunate oversight his paper was published without the author's name. It is entitled “Geologia do Estado do Parana" and appears at pages 67 to 143 of the Boletim do Ministerio da Agricultura, Industria e Commercio, anno V, Rio de Jameiro, 1916. Unfortunately the base map of Paraná mentioned by that writer does not accompany the report and has not been available.

Some good general descriptions of Paraná are given by Henry Lange in his Südbrasilien. Bigg-Wither's book is a valuable work on the State of Paraná, but it has very little on the geology.

General geology.--The geology of the State of Paraná is simple, but it includes an unusually wide geologic time range. On the coast and forming the high escarpment that faces the ocean are the Archean granites, gneisses, schists, and intrusives. Resting directly on the Archean are certain metamorphosed rocks-schists, limestones, and quartzites-that Euzebio de Oliveira calls the Devonian complex. Their precise age is not known, but it seems probable that they, or some of them, represent the older Paleozoic of other parts of Brazil. On these and on the westward slope of the Archean rests the Devonian rocks, which are here represented by a basal conglomerate, the Furnas sandstones, and the Ponta Grossa 
shales, with a total thickness of 250 meters, all of them dipping gently westward. The Ponta Grossa shales have furnished abundant fossils that have been described by John M. Clarke, and there is no uncertainty about the age of the rocks from which they come. Overlying the Devonian beds are the Lower Permian sandstones and shales, with evidences of glaciation, followed by the Upper Permian shales, sandstones, flints, coal, and fossil plants. Both divisions of the Permian cross the entire width of the state from Rio Itararé, São Paulo, to Santa Catharina, on the Iguassú.

West of the Permian are the Triassic sandstones (Botucatú), with their accompanying sheets and dikes of eruptive rocks. In Parana the Triassic beds have thus far furnished no fossils.

Siemiradski thinks the region of the Parana highlands is profoundly faulted. There is no doubt about the existence of faults all through the

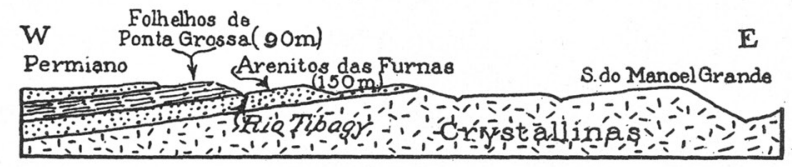

Figure 17.-General east-west Section south of Tibagy, Parana According to Eusebio de Oliveira.

region, but thus far the great dislocations suggested by that geologist have not been verified.*

Economic geology.-Molybdenum is said to occur in the Archean rocks on Rio Capivary, 30 kilometers from Curytiba. Coal of Permian age is found on the Rio das Cinzas, in the northern part of the state, and diamonds have been mined along some of the streams that flow from.and across the Devonian area. The Iraty shales at the base of the Upper Permian are bituminous, and asphalt is said to occur in veins in the Upper Permian in the southern part of the state.

Limestones in the form of lenses in the Archean occur on the Curityba plateau, especially at Pangaré. In the older Paleozoic series are also limestones north of Curityba and between Cachoeira and Rocinha and at Itaiacoca. Limestones are also common in the Permian at many places.

\section{Geologic Maps of Paraná}

I. C. White, 1908.-Accompanying Dr. I. C. White's "Final Report on the Coal Measures . . . of South Brazil" is a map of the States of

* J. von Siemiradski: Geologische Reisebeobachtungen in Sudbrasilien. Sitz. der K. Akad. Wiss. Wien., 1898, 25. 
Rio Grande do Sul, Santa Catharina, Paraná, and part of São Paulo, showing the general distribution of the Permian coal-bearing horizon and of the overlying rocks. Only two geologic divisions are shown, the Tubarão (coal-bearing) series and the overlying beds, and these are not given in detail. The scale of the map is 1 to $2,010,365$. The date on the map is $190 \%$, but the report itself was printed in 1908 .

Euzebio Paulo de Oliveira, 1913.-A small geologic map of a part of the state is given at page 63 of Dr. John M. Clarke's Devonian Fossils of Paraná. It is on a scale of 1 to $1,000,000$ and shows three geologic divisions, namely: Furnas sandstones, the Ponta Grossa shales, and the overlying beds-called Carboniferous in the legend. Though the area represented is but small, the map affords a good key to the geology of the state within the area of the Devonian rocks. The report in which the map appears was published at Rio de Janeiro in 1913.

Euzebio Paulo de Oliveira, 1918.--The Serviço Geologico e Mineralogico do Brasil published at Rio in 1918 a report by Euzebio Paulo de Oliveira entitled "Regiōes carboniferas dos Estados do Sul," which contains an "esboço geologico da ragião-typo do Sul do Brazil," which is really a geologic map of the State of Paraná. It is on a scale of one to two million and eight geologic divisions are shown. This is the best, and indeed the only, geologic map of the State of Paraná.

\section{Bibliography of the Geology of Paraná}

H. Bross : Glaziale Spuren in Paraná Brasilien. Centralblatt für Mineralogie, Geologie und Paleontologie, 1909, No. 18, pages 558-561.

H. Bross : Geologische Streifzüge in Parana (Süd-brasil). Jahresb. Ver. Naturk. Württ., volume LXVI, 1910, pages 82-87.

John M. Clarke: Fosseis devonianos do Parana. Monographia do Serviço Geologico do Brasil, volume I, $4^{\circ}, 353$ paginas. Rio de Janeiro, 1913.

o. A. Derey : Geologia da região diamantifera da Provincia do Paraná no Brazil. Archivos do Museu Nacional do Rio de Janeiro, volume III, paginas 89-96. Rio de Janeiro, 1878. Same article in English. Proceedings of the American Philosophical Society, volume XVIIII, paginas 251258. Philadelphia, 1879.

O. A. Derby : Terrenos carboniferos das provincias de S. Paulo e Paraná. Revista de Engenharia, 28 de Agosto de 1883, volume V, paginas 228-229. Extrahido do Jornal do Commercio do Rio de Janeiro. Rio, 1883. Also in the Auxiliador da Industria Nacional, No. 11, Novembro de 1883, paginas 258-260. Rio de Janeiro, 1883.

E. KaYser: Alguns fosseis paleozoicos do Estado do Parana. Two plates. Revista do Museu Paulista, volume IV, paginas 301-311. São Paulo, 1900. (Devonian invertebrates.)

Jose e Francisco Keller: Exploração dos Rios Tipagy e Paranapanema. Annexo (letra N) ao Relatorio do Ministro da Agricultura, etc., page 25. Rio de Janeiro, 1866. 
K. NeUmaNN : Notizen über das Küstenland der brasilienischen Provinzen Paraná und São Paulo. Zeitschrift für Allgemeine Erdkunde. N. F., volume IX, pages 327-333. Berlin, 1860.

Euzebio Paulo de Oliveira : O terreno devoniano no sul do Brazil. "Patria e Lar," volume II, numbers 7 e 8, paginas 41-52. Curitiba, Janeiro e Fevereiro, 1913.

Euzebio Paulo de Oliveira: Noticia sobre as minas de carvão de pedra da bacia do Rio das Cinzas (Parana). Diario Official, Rio de Janeiro, 22 de Julho de 1916, 8317-8321.

(Euzebio Paulo de Olivetra) : Geologia do Estado do Parana. Boletim do Ministerio da Agricultura, Industria, etc. Anno V, No. 1, paginas 67-143. Rio de Janeiro, 1916. (The article does not have the author's name.)

Euzebio Patro de Outveira: Regiónes carboniferas dos Estados do Sul. Royal $8^{\circ}, 125$ paginas, illustrated, com mappa geologico do estado do Paraná. Serviço Geologico e Mineralogico do Brasil. Rio de Janeiro, 1918.

Dr. Garlos Rath : Fragmentos geologicos e geographicos para a parte physica e estatistica das Provincias de São Paulo e Paraná. Exploradas a proprias expensas do autor, começados no anno de 1845. . . . 78 paginas. São Paulo, 1856.

Jos. v. Srmmrradzkr: Geologische Reisebeobachtungen in Sïdbrasilien. Sitzungsberichte Akademie Wissenschaften Mat.-nat. Band CVII, abstract I, pages 23-39. Wien, 1898.

VIsconde DE TAdNaY: Curiosidades naturaes da provincia do Parana. Revista do Instituto Historico, volume LIII, part 1, paginas 193-241. Rio de Janeiro, 1890.

H. P. Vereker : Report on the Brazilian province of the Parana. Journal of the Royal Geographical Society, volume XXXII, pages 137-142. London (1862). Physical features. Abstract in Proceedings of the Royal Geographical Society, volume VI, page 74. London, 1862.

L. WAgoner: Paraná e Santa Catharina. Revista Industrial, Janeiro de 1878, volume II, pages 9-10. New York, 1878. (Notes on geology and physical features.)

I. C. White: Report on the coal measures and associated rocks of South Brazil. In English and Portuguese, report to the Minister of Industry, etc. Rio de Janeiro, 1908.

J. B. Woodworth : Geological expedition to Brazil and Chile, 1908-1909. Bulletin of the Museum of Comparative Zoology, volume LVI, number 1 . Cambridge, November, 1912.

\section{PERNAMBUCO}

Previous investigations.- - The geography of the state is taken from the maps of the Inspectoria de Obras Contra as Seccas.

The general geology of the State of Pernambuco is fairly well shown in Branner's geology of the northeast coast of Brazil, which was made from personal observations. Notes on the geology of the interior of that State are given by Halfeld along the São Francisco, by Coutinho on the line explored for a railway from Recife to the São Francisco, by Lom- 
bard in his "Exploração da parte sul do estado de Pernambuco," and by Dombre in his "Viagens." A strip in the west end of the state is shown on Small's map of the geology of Piauhy. The fossils from Farinha are dsecribed by Cope, Dall, C. A. White, and Rathbun, and Miss Maury contributes a valuable note on the correlations of the Maria Farinha beds.

The island of Fernando de Noronha belongs to the State of Pernambuco; the geology of that island is described by Branner, Darwin, Daris, Lea, Renaud, Ridley, Geo. H. Williams and Gill, and Costa.

The stone reefs of the State of Pornambuco and the east coast are described by Branner.

General geology.-Rocks of Archean age cover most of the State of Pernambuco. Along the coast is a belt of Tertiary sediments; north of Olinda this belt is about forty kilometers wide, and in some places is underlain with Cretaceous rocks; south of Olinda this belt is only ten or twelve kilometers wide and the rocks are probably all Tertiary. In the extreme western end of the state the mountains along the Piauhy and Ceará frontiers are capped by Cretaceous rocks containing fossil fishes. At several places through the interior old Paleozoic remnants are faulted or folded into the Archean. For lack of data these infaulted areas have not been outlined; one of them is in the Serra Russa between Victoria and Gravatá. A similar area is west of Canhotinho. The outliers of sedimentary rocks between Jatobá and Buique and near Aguas Bellas have thus far yielded no fossils, and the age or ages of those beds is not definitely known. They are referred provisionally to the Upper Permian because they are stratigraphically in the place occupied by the Permian beds at Aracý, Bahia. Lombard supposed the beds at Buique were preCambrian, but there is no evidence in support of such a theory (Lombard, "Relatorio apresentado," page 131. Recife, 1895). Trachytes are exposed on the coast just north of Cape Santo Agostinho, and the island of Santo Aleixo is of rhyolite. The island of Fernando de Noronha is mostly phonolite, but there are some small areas covered by sandstones formed by the hardening of sand-dunes.

The stone reefs characteristic of the Brazilian coast from Ceará to Bahia, inclusive, are well developed at several places on the coast of Pernambuco, notably at Rio Formoso, Recife, and just south of Cape Santo Agostinho. Several Brazilian seaports are formed by stone reefs, namely, those of Pernambuco, Natal, Porto Seguro, and many of minor importance. These reefs are old sand beaches through which water from the land has filtered, consolidating the sand by the precipitation of lime between the sand grains. They vary greatly in length and breadth; the one at Pernambuco is from 20 to 60 meters wide. Their surfaces never rise above high-tide level. 
These sandstone reefs have been in process of formation since Pliocene times and are still being formed. The accompanying cross-sections of the reef at Rio Formoso show their general structure along the entire coast.

Economic geology.-Beautiful crystalline marbles are found at many places in the Archean areas of the state, notably at São Caetano, Floresta, Pajeu de Flores, and Aguas Bellas. Some of these marbles are pure limestones, and are much used in the manufacture of lime for local consumption, while others are dolomites. The rhyolites of the island of Santo Aleixo and the phonolites of Fernando de Noronha have been extensively quarried for street paving blocks. The sandstones of the reefs were formerly much used for building stones and for paving sidewalks in the city of Recife. The use of these sandstones, however, has been wisely
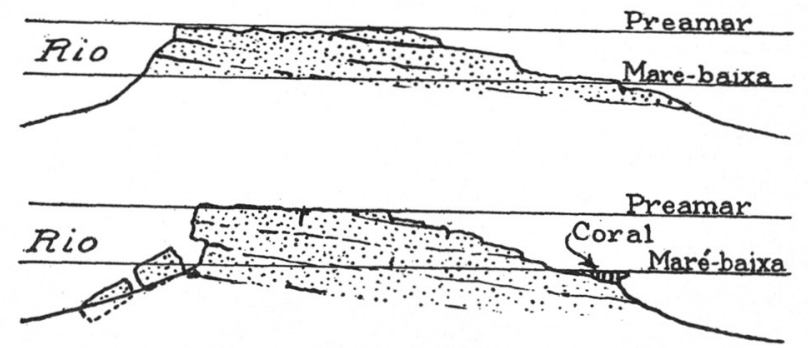

FIGURE 18.-Sections across a typical Sandstone Reef at Rio Formoso, State of Pernambuco

The ocean is on the right. The horizontal lines represent high and low tide.

prohibited on account of the protection afforded the ports and the coast by the stone reefs.

Limestones of Cretaceous age are abundant in the Serra do Araripe, in the northwestern corner of the state. At Maria Farinha on the coast north of Olinda, limestones are found at the base of the Mesozoic sediments.

One may often hear of the existence of rock-salt in the mountains about Buique. The salt that has been made at Buique, however, is obtained by leaching the dry earth or efflorescence gathered from certain sandstones and evaporating the waters.

Saltpeter is also found in the Buique region, but the deposits are formed only on certain porous sandstones where the efflorescence is scraped from rock surfaces on which it is formed by evaporation. ${ }^{79}$

79 L. Lombard: Revista Industrial de Minas Geraes, vol. v, pp. 6-7. Ouro Preto, 20 de Junho de 1897. 
On Ilha Rapta, one of the islands forming the Fernando de Noronha group, are limited phosphate deposits that attracted considerable attention at one time. Analyses of the materials are given by Lima José Ig. d'Abreu and by Lasne. Attempts were made to export these phosphates, but, owing to the difficulty of loading them, the enterprise was soon abandoned.

\section{Geologic Map of Pernambuco}

Branner, 1902.-A geologic sketch-map of "the region about Pernambuco" forms plate 11 of Branner's paper on the geology of the northeast coast of Brazil (opposite page 62 of volume 13, Bulletin of the Geological Society of America, 1902). It is on a scale of 1 to 1,000,000 and shows only two divisions-the Archean and the Tertiary.

The geology of the extreme western end of the state is shown on the map accompanying Small's Geologia e supprimento d'agua . . . no Piauhy, publicacão 32, da Inspectoria de Obras Contra as Seccas, Rio de Janeiro, 1914.

\section{Bibliography of the Geology of Pernambuco}

J C. Branner: Notes on the islands of Fernando de Noronha. American Naturalist, volume XXII, October, 1888, pages 861-871, $8^{\circ}$. Philadelphia, 1888.

J. C. Branngr: The aeolian sandstone of Fernando de Noronha. American Journal of Science, April, 1890, volume XXXIX, pages 247-257. New Haven, 1890.

J. C. Branner: The geology of Fernando de Noronha. Part I. (For Part II, see G. H. Williams.) American Journal of Science, volume XXXVII, pages 145-161. New Haven, 1889.

J. C. Branner : Geologia de Fernando de Noronha. Revista do Instituto Archeologico e Geographico Pernambucano, Abril de 1890, paginas 20-22. Pernambuco, 1890. (Abstract of the preceding article.)

J. C. Branner: Os grés élios de Fernando de Noronha. Revista do Instituto Archeologico e Geographico Pernambucano, No. 44, paginas 161-171. $8^{\circ}$. Pernambuco, 1893.

J. G. Branner: Os recifes de grés do Rio Formoso. Revista do Instituto Archeologico e Geographico Pernambucano, No. 54, anno XXXVIII, paginas 131-136, map and illustrated. $8^{\circ}$. Pernambuco, 1901.

J. C. Branner: Geology of the northeast coast of Brazil. Bulletin of the Geological Saciety of America, volume 8, 1901, pages 41-98, illustrated. $8^{\circ}$. Rochester, 1902.

I C. BranNer: The occurrence of fossil remains of mammals in the interior of the States of Pernambuco and Alagoas, Brazil. American Journal of Science, volume XIII, February, 1902, pages 133-137, one illustration. New Haven, 1902. 
J. C. Branner: The stone reefs of Brazil. Bulletin of the Museum of Comparative Zoology, volume XLIV. Cambridge, Massachusetts, 1904.

Francisco augusto Pereira da Costa: A Ilha de Fernando de Noronha. Noticia historica, geographica e economica. Mandada publicar pelo Exm. Sr. Presidente da Provincia Dr. Pedro Vicente de Azevedo. 117 paginas. Pernambuco, 1887. (Geology, pages 7-8, 10-12, 54-62.)

F. A. Perema da. Costa: Mineralogia (de Pernambuco). Jornal do. Commercio, Rio de Janeiro, 5, 8, e 19 de Julho de 1897.

J. M. Da Silva Coutinho: Estrada de ferro do Recife ao S. Francisco. Estudos definitivos de Una á Boa Vista. Rio de Janeiro, 1874. Geology, paginas $7-8,11,14-18,23-24$.

Charles Darwin: Geological observations on the volcanic islands and parts of South America visited during the voyage of $\mathbf{H}$. M. S. Beagle. Maps and illustrations. London, second edition, 1876. References to Brazilian geology, pages $27-28$; 193 , footnote; $422-428$.

Thomas Davies: The natural history of the island of Fernando de Noronha. Linnean Society's Journal, Botany, volume XXVI, pages 86-94. London, 1890.

L. E. Dombrt: Viagens do Engenheiro Dombré ao interior da provincia de Pernambuco em 1874 e 1875. $8^{\circ}, 86$ paginas. Recife, 1893.

A. C. GILL: Petrographical notes on a rock collection from Fernando de Noronha. Johns Hopkins University Circulars, volume VII, number 65, pages 71-72. Baltimore, 1888.

H. G. F. HALFeld : Atlas e relatorio concernente a exploração do Rio de São Francisco desde a Cachoeira da Pirapóia até o Oceano Atlantico. 57 paginas, folio, 36 maps. Rio de Janeiro, 1860.

Char. Fred. HaktT: Relatorio preliminar dos trabalhos da Commissão Geologica na provincia de Pernambuco. $8^{\circ}, 11$ paginas. Rio de Janeiro, 1875.

Dr. H. von Inering: As ilhas oceanicas do Brazil. A ilha de Fernando de Noronha. Revista Brazileira, Outubro de 1895, volume IV, paginas 101108; Novembro de 1895, volume IV, pages 164-173. Rio de Janeiro, 1895.

Rev. T. S. LeA: The island of Fernando do (sic) Noronha in 1887. Proceedings of the Royal Geographical Society, volume X, July, 1888, pages 424435. London, 1888.

Jose Ianacio de ABbeu e Lima: Apontamentos sobre a Ilha de Fernando de Noronha em 1857. Revista do Instituto Archeologico e Geographico Pernambucano, No. 38. Pernambuco, 1890. Aspecto da llha com notas sobre a geologia, paginas 7-9.

L. LoMbard: Relatorio apresentado ao Exm. Sr. Governador do Estado, etc. Pelo Dr. Rodolpho Galvão, Sec. dos Negocios da Industria, Recife, 1895. Annexos contain : Projecto de organisação da carta geographica e geologica do Estado de Pernambuco, paginas 105-122 (an. rep.). Relatorio sobre a exploração mineralogica de Garanhuns á Buique e da zona salitrosa de Buique, paginas 123-141. $8^{\circ}$, with 2 maps. Also in Revista Industrial de Minas Geraes, Anno IV, No. 24, 10 de Maio de 1897, paginas 310-313. V, No. 25, 20 de Junho de 1897, paginas 6-8. Ouro Preto, 1897.

L. LoMbard : Relatorio sobre a exploração da parte sul do Estado de Pernambuco entre Palmares e Bom Conselho. Por L. Lombard. Relatorio apresentado ao Exm. Sr. Governador do Estado Dr. Alexandre José Barbosa 
Lima pelo Dr. Rodolpho Galvão, Secretario dos Negocios da Industria. $8^{\circ}$. Recife, 1895. Relatorio de Lombard, paginas 51-62 e cartas.

Carlotta J. MaURY: A contribution to the paleontology of Trinidad. Journal of the Academy of Natural Sciences, Philadelphia, volume XV, pages 32-33. Philadelphia, 1912.

G. T. PrIor: Note on the occurrence of rocks allied to Monchiquite in the island of Fernando de Noronha. Mineralogical Magazine and Journal of the Mineralogical Society, volume XI, number 52, pages 171-175. London, 1897. Reprint, pages 1-5.

Richard Rathbun : Preliminary report on the Cretaceous lamellibranchs collected in the vicinity of Pernambuco, Brazil, on the Morgan Expedition of 1870, Ch. F. Hartt in charge. Proceedings of the Boston Society of Natural History, pages 241-256. Boston, 1875.

Alexander RATTray: On the geology of Fernando de Noronha. Quarterly Journal of the Geological Society, volume XXVIII, November, 1871, pages 31-34. London, 1872.

alexander Ratrray: A visit to Fernando de Noronha. Journal of the Royal Geographical Society, volume XLII, pages 431-437. London, 1872.

W. REay, JR. : Mining explorations in Brazil. The Province of Parahyba and Pernambuco. The Mining Journal, volume XXXIV, February 13, 1864, page 106. London, 1864.

A. ReNard: Notice sur les roches de l'ile de Fernando de Noronha, recueillies pendant l'expédition du Challenger. Bulletin de l'Academie Royale de Belgique, 3me série, volume III, No. 4, 12 pages, 1 plate Separate. Bruxelles, F. Hayez Imp., 1882.

A. RenarD: On some rock specimens from the islands of the Fernando de Noronha group. Geological Magazine, volume III, page 33. London, 1886. Also, Report of the British Association for the Advancement of Science (Aberdeen), 1885, Section C, page 1031. London, 1886.

Professor A. RENARD : Report on the rock specimens collected on oceanic islands during the voyage of Her Majesty's ship Challenger during the years 18731876. The voyage of Her Majesty's ship Challenger. Physics and Chemistry, volume II, $4^{\circ}$. London, 1889. Rocks of Fernando de Noronha, pages 29-39 of the petrographical part.

SpIx und MarTIUs: Reise in Brasilien, volume II, pages 754-801. München, 1828.

H. N. RIDLeY : (Notes on the geology of Fernando de Noronha) quoted in Thomas Davies, Geology (of Fernando de Noronha), page 90 of the natural history of the 1sland of Fernando de Noronha, based on the collection made by the British Museum Expedition in 1887, from the Journal of the Linnæan Society. (London), 1890. Iinnæan Society Journal, Botany, volume XXVII.

Henky N. RmbeY: The raised reefs of Fernando de Noronha. American Journal of Science, third series, volume XLI, pages 406-409. New Haven, 1891.

W. H. B. Webster : A narrative of the voyage to the southern Atlantic Ocean in the years 1828-9-30, performed in Her Majesty's sloop Chanticleer. Two volumes, $8^{\circ}$. London, 1834. (Fernando de Noronba, volume II, pages 326-331, 14-16.) 
Charles A. White: Contribuições a Paleontologia do Brasil (com o original em inglez). Archivos do Museu Nacional, volume VII, $4^{\circ}$, paginas 1-273, and 28 plates. Rio de Janeiro, 1887. Three hundred and fifty copies of this report were issued as a special edition, dated Washington, January 21, 1888, under the title "Contributions to the paleontology of Brazil; comprising descriptions of Cretaceous invertebrate fossils, mainly from the provinces of Sergipe, Pernambuco, Pará, and Bahia."

Dr. Geo. H. Wuldams: Description of the rhyolite from Santo Aleixo and Ilhas, Province of Pernambuco. The Cretaceous and Tertiary geology of the Sergipe-Alagôas basin of Brazil, by J. C. Branner. Transactions of the American Philosophical Society, 1889, volume XVI, page 404, footnote.

Geo. H. Williams: Geology of Fernando de Noronha. Petrography, part II. [For part I, V. Branner.] American Journal of Science, volume CXXXVII, pages 178-189. New Haven, 1889. Abstract of parts I and II in Neues Jahrbuch für Mineralogie, 1890, volume I, page 85. [Referate.]

E. Williamson: Geology of Paraiba and Pernambuco gold regions. Transactions of the Manchester Geological Society, volume VI, pages 113-122. Sessions of 1886-1887. Manchester, 1868.

\section{PIAUHY}

Previous investigations.-The map of Piauhy east of Floriano is taken from Small's Mappa geologico do Piauhy, published in 1914 by the Inspectoria de Obras contra as Seccas under Dr. M. A. R. Lisboa, while the part west of Floriano is from the map published by Dr. José Estacio de Lima Brandão under the Inspectoria Federal das Estradas in 1913.

There are two important papers on the geology of Piauhy, that of Dr. Lisboa on the Permian geology of northern Brazil, and that of H. L. Small on the "Geologia e agua subterranea de Piauhy e Ceará." Since these papers came out I have received specimens of Psaronius from Rio Parnahyba below Philomena which show the further extension of the Permian in the southern part of the state. The notes of George Gardner, of Spix and Martius, and of J. W. Wells are fragmentary, but useful.

General geology.-The Archean rocks are exposed in Piauhy only in the southeastern part of the state, where it joins Ceará, Pernambuco, and Bahia, and in a small area near the north end of Serra Grande.

The oldest sedimentary beds known in the state are those of the Serra Grande, supposed to be of lower Permian age. These rocks are conglomerates, sandstones, limestones, and calcareous shales. The strata are often false-bedded, and the series has a maximum thickness of 700 meters. The beds dip toward the west or northwest, at an angle of from four to seven degrees. No fossils have been found in the rocks of this group in Piauhy and their age is not certainly known.

Overlying the Serra Grande series are the Upper Permian sediments, which consist of a series of horizontal, reddish calcareous sandstones and 
shales having a thickness varying from 100 meters or less in the valleys to more than 500 meters in the high mountains. Mr. Small gives the following order and thickness of the Permian rocks of Piauhy::00

Thickness in meters

1. Upper yellow sandstone, sometimes false-bedded.............. 250

2. Middle sandstones and sandy shales...................... 200

3. Sandstones and lower shales........................... 70

The determination of the Permian age of this series rests on the presence of Psaronius, which has been found by Dr. Lisboa at many places in this state and in Maranhão, and on a Sigillaria found by Mr. Small 30 kilometers east of Valença, near the east base of the Serra Baptista.

In the southeast corner of the state Cretaceous beds overlie the Upper Permian beds at a few places. The western end of the Serra do Araripe, where it projects into Piauhy, is known as the Serra Vermelha. The upper portion of that mountain is made of the same kinds of horizontal Cretaceous sedimentary beds as those of the Serra do Araripe. A little farther south, on the divide between the States of Piauhy and Pernambuco, is the Serra de Dois Irmãos, which, together with a small outlier to the west of it, is likewise Cretaceous. All of these Cretaceous areas of Ceará, Piauhy, and Pernambuco are merely the remnants of the original wide-spread beds of Cretaceous age. A fuller description of the Cretaceous geology of this region is given under the notes on the geology of Ceará. At several places eruptive rocks appear at the surface, notably at Valença, on the headwaters of Rio Berlenga, and at fazenda Grauta northwest of Picos.

Economic geology.-Piauhy is an agricultural and pastoral rather than a mineral-producing state. The geology in its relations to underground water is of special interest and has been reported on by H. L. Small. (See bibliography.) Iron of excellent quality has been reported, but nothing is now. known of the quality or of the quantity available.

\section{Geologic Maps of Piauhy}

Lisboa, May, 1914.-Dr. M. A. R. Lisboa's paper on the Permian geology of northern Brazil, published in the American Journal of Science for May, 1914, pages $425-443$, is accompanied by a small-scale sketchmap showing the geology of a large part of the State of Piauhy. The scale is 1 to $11,428,570$ and four geologic subdivisions are shown, namely: crystalline rocks, Permian, Triassic, and Cretaceous.

${ }^{80}$ Relatorio, pp. 64-65. 
Small, June, 1914.-In his report to the Inspectoria de Obras Contra as Seccas, publicação number 32, on the geology and underground waters of Piauhy, etcetera, Mr. H. L. Small gives a geologic map of the eastern and northern parts of the State of Piauhy. It is on a scale of 1 to $1,000,000$ and shows seven geologic subdivisions. The map does not include the southwestern part of the state west of latitude 43 degrees, but it does include the western portion of the States of Ceara and Pernambuco. The map is accompanied by sections showing the geologic structure.

\section{Bibliography of the Geology of Piauhy}

Gustayo L. G. Dodt : Relatorio acerca da Exploração do Rio Parnahyba por ordem da Presidencia da Provincia de Piauhy. Annexo " $O$ " do relatorio da Repartição dos negocios da Agricultura, etc., pages 1-58. $4^{\circ}$. Rio de Janeiro, 1872. Consideracões geraes, pages 20-23.

Geobae Gardner: Travels in the interior of Brazil, principally through the northern provinces and the gold and diamond districts, during the years 1836-1841. $x v i+562$ pages. London, 1846 . Second edition, xviii +428 pages. London, 1849. (Piauhy, pages 169-243.)

M. A. R. LrsBoA: Permian geology of northern Brazil. American Journal of Science, May, 1914, volume 187 , pages $425-443$.

H. L. SMaLL: Geologia e supprimento d'agua subterranea no Piauhy e parte do Ceará. Publicação No. 32 da Inspectoria de Obras contra as Seccas. Royal $8^{\circ}$, illustrated, maps, 147 paginas. Rio de Janeiro, Junho de 1914.

SpIx und Martius: Reise in Brasilien, 1828, volume II, pages 770-809. München, $4^{\circ}$, and Geographischer Anhang.

Franciscus Unger: Historia naturalis palmarum, Auctor, C. F. Ph. de Martius. Lipsiæ (1850?). I, Caput secundum. De palmis fossilibus, page lxx, tab. geol. I, figure 4, a fossil palm, Psaronius brasiliensis Brongn., from the Province of Piauhy.

J. W. WELLs: Exploring and traveling three thousand miles through Brazil from Rio de Janeiro to Maranhão. Two volumes. London, 1886. Occasional geological notes. Appendix II, volume II : Extracts from a paper read at a meeting of the Royal Geographical Society on the 8th of February, 1886, and entitled "A sketch of the physical geography of Brazil," pages 359-374.

J. W. WeLLs : Notes of a journey from the River St. Francisco to the River Tocantins and to the city of Maranhão. Journal of the Royal Geographical Society, volume XLVI, pages 308-328, map. London, 1876.

RIO DE JANEIRO, THE FEDERAL DISTRICT, AND TRINIDADE

Previous investigations.-This territory includes the Federal District and the island of Trindade.

Almost every geological visitor to Brazil has stopped at Rio de Janeiro and has had something to say about the geology in and about that city. The geology, however, is rather monotonous and the notes usually begin 
and end with the remark that the rocks are granites and gneisses. The most comprehensive papers are those of Pissis, Eschwege, Caldcleugh, Derby on the eruptives in Rio de Janeiro, and of Alberto Paes Leme on "os gneiss do Rio de Janeiro." Others are mostly field-notes; such are those of Burmeister, Hartt, Burton, Collie, Eschwege, and D'Orbigny.

The island of Trindade, in south latitude $20^{\circ} 30^{\prime}$, west longitude $29^{\circ}$ $25^{\prime}$, belongs to the Federal Union and, together with the Federal District, is here included with the State of Rio de Janeiro. The island is shown as an inset on the map of Brazil.

General geology.-Archean rocks cover all of the state except a narrow belt of Tertiary and Quaternary sediments on the coast and some isolated patches of Tertiary lake deposits in the valley of the Parahyba.

Of the geologic structure of the State of Rio de Janeiro but little is known, for the character of the rocks, the depth of decomposition, and the presence of dense forests render field-work difficult and unsatisfactory. The only attempt to work out the structure of any considerable part of the geology about the city of Rio de Janeiro is reported in the paper of Alberto Paes Leme, entitled "Estudo geologico de uma parte do districto federal," cited in the bibliography that follows. It seems evident at a glance that the granites, gneisses, schists, and eruptives of the region have been much faulted, profoundly decomposed, and extensively denuded. The Tertiary lake beds referred to have been reported only from two places in the State of Rio de Janeiro, namely, Barra Mansa and Rezende. They are evidently the eastward prolongations of the Tertiary beds found at Taubaté, but separated by denudation from the larger original areas.

At many places near the coast lakes have been shut in by Quaternary and late sediments that have been thrown into the embayments by the ocean. The geography of the coastal region is especially interesting, and a careful study of it would throw much light on the geological history of the region and of the country. But little attention has been given to this subject, however. It is spoken of briefly in Branner's "Stone reefs of Brazil," at pages 124, 128, and 132.

The uninhabited island of Trindade is entirely of eruptive rocksphonolites.

Economic geology.-The economic geologic products of the State of Rio de Janeiro, including the Federal District, are limited chiefly to building stones, marbles, and ceramic clays.

The quarrying industries of the state, and especially those in and near the city of Rio de Janeiro, are of great importance and have had a striking influence on the character, dignity, and stability of the architecture 
and port works, not only of Rio de Janeiro itself, but on the architecture of all of the coast cities of Brazil as well.

In the Archean area there are crystalline marbles which, though as yet but little used, must in time come into the market, both for building and ornamental purposes, and also for the production of lime and possibly of Portland cement. Such limestones are known at Macuco and Santa Rita near Catagallo, on Rio Muriahé above Caxoeira, at Sant' Anna north of Rezende, near Barra Mansa, and near Barra do Pirahy, and in the mountains east of Belem.

It is possible that in the areas of Tertiary lake deposits near Barra Mansa and Rezende there may be found bituminous shales similar to those at Taubaté.

\section{Geologic Maps of Rio de Janeiro}

Pissis, 1842.--In 1842 A. Pissis presented to the Academy of Sciences of Paris a "Mémoire sur la position géologique des terrains de la partie australe du Brésil," etcetera, and that paper was accompanied by a geologic map that embraced the region between the city of Bahia on the north and east and Piracicaba, in the province of São Paulo. It therefore included the entire provinces of Rio de Janeiro and Espirito Santo and large parts of Bahia, Minas, and São Paulo. The map was on a scale of 1 to about 2,500,000. The geologic divisions were: one for finegrained granite; four for the "terrain primitif"; two for the "periode phylladienne"; one for diorite, and two for the Tertiary. The map and the accompanying sections show a correct acquaintance with local details of the geology at many points, but the generalizations for the large areas embraced are far from correct; nor do they give a clear idea of the general geology.

Alberto Betim Paes Leme, 1912.-In his pamphlet entitled " $O \mathrm{~s}$ gneisses do Rio de Janeiro," published at Rio de Janeìro in 1912, Dr. Alberto Betim Paes Leme gives a geologic map covering an area of 175 square kilometers in the State of Rio de Janeiro, including part of the city of Rio and the region 18 kilometers to the west of it. The map is on a scale of 1 to 50,000 , four divisions of the granitic rocks are shown, and the diabase is put in diagrammatically.

\section{Bibliography of the Geology of Rio de Janeiro}

J. C. Branner: The supposed glaciation of Brazil. Journal of Geology, volume I, pages 753-772. $8^{\circ}$. Chicago, 1893.

JohN C. Branner : Decomposition of rocks in Brazil. Bulletin of the Geological Society of America, volume 7, pages 255-314. Rochester, 1896. 
Pedro Torquato Xavier de Brito: Memoria historica e geographica da Ilha de Trindade. Revista do Instituto Historico, volume XL, parte II, paginas 249-275. Rio, 1877.

Dr. HERmany BURMeistrar: Reise nach Brasilien, durch die Provinzen von Rio de Janeiro und Minas Geraes. Berlin, 1853.

Captain RTchard F. Burton: Explorations of the highlands of the (sic) Brazil ; with a full account of the gold and diamond mines. Two volumes, $8^{\circ}$. London, Tinsley Brothers, 1869. (Contains many observations on the geology.)

Alexander Caldcheuge : Travels in South America during the years 1819-2021 ; containing an account of the present state of Brazil, Buenos Aires, and Chile. Two volumes, $8^{\circ}$. London, John Murray, 1825. Volume I, $x i i+373$ pages; volume II, viii $+\mathbf{3 8 0}$ pages. (Notes on the geology.)

Francis de Castelinau et Eugene d'Osery: Expedition dans les parties centrales de l'Amerique du Sud . . . pendant les années 1843 a 1847. Quatrième partie. Paris, 1852.

4. Chevarier : Voyage autour du monde exécuté pendant les années 1836 et 1837 sur la corvette $L a$ Bonite. Géologie et Mineralogie du Brésil, pages 17-45. Paris, 1844.

A. CoLtre: Geological observations in the neighborhood of Rio de Janeiro. Page 159 of "Geology," from volume II (Zoology) of the Narrative of a voyage to the Pacific and Behring Strait . . . in His Majesty's ship Blossom, under the command of Capt. F. W. Beechey. Two volumes. London, 1831.

O. A. DerBy : On Nepheline rocks in Brazil. Part I, with special reference to the association of phonolite and foyaite. Quarterly Journal of the Geological Society of London, volume XLIII, pages 457-473. London, 1887. Volume XLVII, pages 251-265. London, 1891. The same in Portuguese: Revista de Engenharia, volume $X$, pages 111-114, 121-123, 133-136. Rio de Janeiro, 1888.

O. A. DerRy : Observacões sobre os calcareos do Rio de Janeiro, etc. Revista da Engenharia, volume VI, paginas 26-28. Rio de Janeiro, 14 de Fevereiro de 1884.

Alcroe D'Orbigny : Voyage dans l'Amerique méridionale; (le Brésil, la République Orientale de l'Uruguay, etcetera), executé pendant les années, 1826

(a) 1833. $4^{\circ}$. Paris, 1835-1847. Géologie, Tome III, 3e partie, pages 1719. Paris, 1842.

W. L. von Esch WeGe: Pluto Brasiliensis. Berlin, G. Reimer, $1833,8^{\circ}$, xviii + 622 paginas, Cap. 5, parte 3a, traduzido por Rodolpho Jacob, e publicado na Revista do Archivo Publico Mineiro. Anno II, fasciculo 4, Outubro a Dezembro de 1897, paginas 611-672. Ouro Preto, 1897. Cap. 2, parte I, mesmo. Anno III, fas. II, 1898, paginas 433-463. Bello Horizonte, 1898. Cap. I, partẻ III, mesmo, Anno III, fas. III e IV, 1898, paginas 519-577. Bello Horizonte, 1898.

W. L. voN EschWEGE: Beiträge zur Gebirgskunde Brasiliens. Mit vier petrographisch-geognostischen Karten und Profildurchschnitten. $8^{\circ}, \mathbf{x v}+488$ pages. Berlin, 1832.

G. C. (sic) D'EschweaE: Voyage de Rio Janeiro au Comarca d'Ilha Grande fait en 1810. Bxtr. du Journal von Brasilien. Nouvelles Annales des Voyages, volume XX, pages 289-328. Paris, 1823. 
George Gardner: Travels in the interior of Brazil, principally through the northern provinces and the gold and diamond districts, during the years 1836-1841. $8^{\circ}$, xvi +562 pages, map. London, 1846. Second edition, xviii +428 pages, map and plate. $8^{\circ}$. London, 1849. Many notes on the geology, especially of the interior of Ceara, Piauhy, and Minas Geraes.

C. GAUdichaUd: Voyage autour du monde . . . executée sur les corvettes de S. M. l'Uranie et la Physicienne pendant les années 1817-1820 par M. Louls Freycinet. Volume I, Géologie du Rio de Janefro, pages 9-10. Paris, 1826.

J. Fr. Grafte: Mineralogisch-petrographische Untersuchung von Eläolithsyeniten von Serra de Tinguá, Provinz Rio de Janeiro, Brasilien. Neues Jahrbuch für Mineralogie, volume II, pages 222-262. Stuttgart, 1887.

Ch. Fred. Harts: Geology and physical geography of Brazil. Boston, 1870. (Rio de Janeiro, pages 1-55.)

Heusser : Ein Beitrag zur Kenntniss des Brasilianischen Küstengebirge. Zeitschrift der Deutschen Geologie Gesellschaft, volume $X$, pages 412-422. Berlin, 1858.

J. Ch. Heusser und G. Glabaz: Ein fernerer Beitrag zur Kenntniss des Brasilianischen Küstengebirge. Vierteljahrschrift der Naturforschenden Gesellschaft in Zurich, volume $\mathrm{X}$, pages 60-64. Zurich, 1865.

Finst Hofmann : Geognostische Beobachtungen, angestellt auf einer Reise um die Welt, in den Jahren 1823 bis 1826 unter den Befehl des Russisch Kaiserl. Flott-Capitaines und Ritters, Herrn Otto von Kotzebue. Die Umgebungen von Rio Janeiro. Archiv für Mineralogie, Geognosie, Bergbau und Hüttenkunde. Herausgegeben von Dr. C. J. B. Karsten, volume I, 2 Heft, pages 243-251. Berlin, 1829.

F. Hussak : Ueber Leucit Pseudokrystalle im Phonolith (Tinguait) der Serra de Tingua, Estado do Rio de Janeiro, Brazil. Neues Jahrbuch für Mineralogie, volume I, 1890, pages 166-169.

Arberto Betrm Paes Leme: Estudo geologico de uma parte do districto federal. 20 paginas. Rio de Janeiro, 1910.

alberto Betim Paes Leme: Os gneisses do Rio de Janeiro. 38 paginas. Rio de Janeiro, 1912.

R. MoCormick: Voyage of discovery in the Arctic and Antarctic seas. (On the rocks of Trindade, volume I, pages 23-25.) London, 1884.

Oarlos Morkira e E. HemedorfF : Excursões no Itatiaia, Serra de Mantiqueira. Archivos do Museu Nacional, volume XII, paginas 159 et seq. Rio de Janeiro, 1903.

Ladistad NeTto: (Exame das rochas da encosta do Corcovado.) Diario Official, Rio de Janeiro, 26 de Ontubro de 1868.

Justin NoRBerT: Relatorio dos trabalhos de explorações e sondagens feitos pelo engenheiro Justin Norbert, commissionado pelo governo do Estado do Rio de Janeiro, em 1908. Jornal do Commercio, Rio de Janeiro, 15 de Maio de 1909 , paginas 5-6.

A. PIssrs: Notice géognostique sur la province de Rio de Janeiro. Annales des Sciences Géologiques ou Archives de Géologie, etc., volume I, pages 244-249. Paris, 1842.

Jонг Ем PонL: Beyträge zur Gebirgskunde Brasilien. Wien, 1832. 
G. T. Prion: Rock specimens collected in the little island of Trindade, south Atlantic, by the Antarctic Expedition of 1839-1843, under Sir James Clark Ross: Mineralogical Magazine, volume XII, pages 317-323. London, November, 1900.

Dr. José Americo dos Santos: Cal de marisco. Revista de Engenharia, Anno II, No. 1, 15 de Janeiro de 1880, paginas 4-7. Rio de Janeiro, 1860. Revista Industrial, Novembro de 1879, volume V, paginas 137-138. (Dated 11 de Agosto de 1879.) New York, 1879. (Shell deposits about Rio de Janeiro.)

Scouler: Account of a voyage to Madeira, Brazil, Juan Fernandez, and the Galapagos Islands, performed in 1824 and 1825, with a view of examining the ir natural history, etc. Edinburgh Journal of Science, October, 1826, volume V, pages 195-201. Edinburgh, 1826. Notes on the geology of Rio de Janeiro.

José J'RANklin DA Sulva: Descripção do Itatiáia ou Ititiaio. With figure. (Dated December 3, 1856.) Revista do Instituto Historico do Brazil. Tomo XXXIX, parte I, paginas 413-418. Rio de Janeiro, 1876.

Augusto Fausto de Souza: A Bahia do Rio de Janeiro, sua historia e descripção de suas riquezas. Revista do Instituto Historico, Tomo XLIV, parte II, paginas 5 et seq. Rio de Janeiro, 1881. Descripção geral e geologia, paginas 71-73.

SpIx und Martius: Reise in Brasilien, volume I, pages 89-178. Munich, 1823. Barão de Villa Franca: Turfas em Macahé e Campos. O Novo Mundo. Outubro 23, 1875, VI, 19. New York, 1875. Extr. do Monitor Campista.

Fred. E. Wright : Die foyaitisch-theralitischen Eruptivgesteine der Insel Cabo Frio, Rio de Janeiro, Brasilien. Tschermak's Mineralogische und Petrographische Mittheilungen, volume XX, pages 234-259, 273-306, with plates. Vienna, 1901.

\section{RIO GRANDE DO NORTE}

Previous investigations.-The papers of Branner, Crandall, Jenkins, Soper, and Waring are the only ones that treat of the geology of the State of Rio Grande do Norte. There are a few notes, however, by Koster and Burlamaqui.

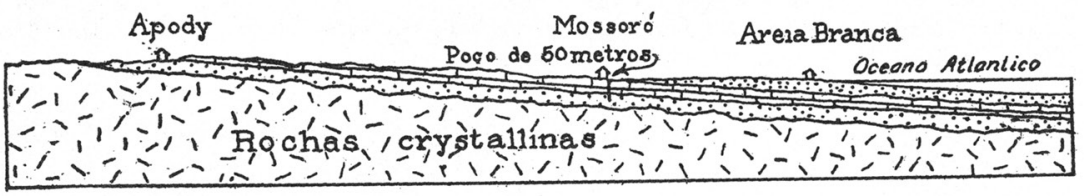

FIGURE 19.-Typical Section from the Archean in the Interior to the Ocean on the Coast of Rio Grande do Norte

R. H. Soper.

General geology.-The interior of Rio Grande do Norte is of Archean rocks; overlapping these old rocks is a belt or zone of Cretaceous and Tertiary marine sediments along the entire coast. This belt varies in 
width from about thirty kilometers in the vicinity of Natal and south of there to a width of 130 kilometers about Mossoró. A few remnants of the coastal sediments cap the mountains south of Mossoró, known as Porto Alegre, Martins, and João do Valle.

The Archean rocks are cut by dikes and by quartz veins, and there are patches of old Paleozoic quartzites let down into the Archean rocks by faults.

Economic geology.-The sedimentary belt contains limestones, and there are also occasional crystalline limestones in the Archean areas.

Mica and asbestos are reported from the Archean area, and clays for the manufacture of bricks, tiles, and common pottery are abundant in the coastal sedimentary belt. Sands for the manufacture of common glass are abundant.

\section{Geologic Maps of Rio Grande do Norte}

Branner, 1901.-A sketch-map showing the geology of the southern coastal region of Rio Grande do Norte was published, as plate 15 of Branner's paper on the geology of the northeast coast of Brazil, in the Bulletin of the Geological Society of America, volume 13, opposite page 93, 1901. The details of Branner's map at and north of Natal were corrected by Jenkins' map, published in 1913.

R. H. Soper, 1913.-A report made to the Inspectoria do Obras Contra as Seccas by R. H. Soper in 1913, under the title "Geologia e supprimento d'agua subterranea no Rio Grande do Norte e'Parahyba" (publication number 26), is accompanied by a geologic map of Rio Grande do Norte. It is on a scale of 1 to $1,000,000$ and shows four subdivisions, namely: (1) gneisses, granites, and schists, (2) sandstones, (3) limestone, and (4) sands and clays.

R. H. Soper, 1916.-A paper by R. H. Soper, entitled "The geology of Parahyba and Rio Grande do Norte, Brazil," and published in volume LV of the Proceedings of the American Philosophical Society in 1916, contains a small map showing the geology of that State. It is on a scale of 1 to 2,941,176 and shows four geologic subdivisions, namely: Paleozoic, late Cretaceous to early Tertiary sandstones, late Cretaceous to early Tertiary limestones, and Recent to Tertiary sands and clays.

\section{Bibliography of the Geology of Rio Grande do Norte}

J. C. Branner : Geology of the northeast coast of Brazil. Bulletin of the Geological Society of America, 1901, volume 13, pages 41-98. Rochester, 1902.

Frederico Leopoldo Cesar Bublamaque: Noticia acerca dos animaes de raças extinctas, descobertos em varios pontos do Brazil. Bibliotheca Guana- 
barense. Trabalhos da Sociedade Vellosiana, 1855, paginas 1-21 (2a parte). Rio de Janeiro, 1855 (?).

R. Crandall: Geographia, geologia, supprimento d'agua, transportes e açudagem nos estados orientaes do norte do Brazil, Ceara, Rio Grande do Norte, Parahyba. Publicação No. 4, Serie I. D. E. Inspectoria de Obras Contra as Seccas. Rio de Janeiro, Outubro, 1910.

Ozaf P. Jenkins: Geology of the region about Natal, Rio Grande do Norte, Brazil. Proceedings of the American Philosophical Society, volume LII, pages 431-466. Philadelphia, September-October, 1913.

HenRy Koster: Travels in Brazil. Second edition, in two volumes. London, 1817. Volume I. Notes on the geology of Rio Grande do Norte, volume I, pages 86-151.

RALPH.H. SoPER: Geologia e supprimento d'agua subterranea no Rio Grande do Norte e Parahyba. Publicação No. 26 de Inspectoria de Obras contra as Seccas, Ministerio da Viação e Obras Publicas. $8^{\circ}$, illustrated, 62 paginas. Rio de Janeiro, Julho, 1913.

G. A. Warivg: Reef formations of the northeast coast of Brazil. American Journal of Science, volume 187, pages 367-390. May, 1914.

\section{RIO GRANDE DO SUL}

Previous investigations.-The base map of the State has been constructed from the list of latitudes and longitudes published by Dr. H. Morize, of the Observatorio Nacional at Rio de Janeiro, and from the map of the State "Organizado na Directoria da Viação da Secretaria das Obras Publicas . . . 1907-1911," but without the name of the author.

The literature relating to the geology of Rio Grande do Sul has always been overshadowed by the importance of the coal found in that state. Every writer on the geology has felt it to be his duty to enlarge on or to repeat the oft-repeated descriptions of the coal deposits, coal mines, operations, and exports. The gold and copper deposits have also come in for their share of interest, while the general geology of the state has received but scant attention.

Valuable contributions to the geology of the state have been suggested by the work done in Uruguay by Walther and Guellemain, while the work of Walther in the vicinity of Lavras and Cacipava is among the best papers on the geology of that state.

The work of Dr. F. A. de Vasconcellos Pereira Cabral, done on the coal regions and published in 1851 , is not only a valuable contribution to Brazilian geology, but it still stands as an excellent and thoroughly conscientious piece of detailed work at a time when the data obtainable from the coal mines were not available and when there was but little interest in the geology of the state.

Sellow's notes on Rio Grande do Sul are excellent, though they were made in 1823 and in spite of the fact that it is difficult to locate many of 
the places mentioned by him. The notes of Sellow and of other geologists give the impression that the region of granites and gneisses south of the trap escarpment contain many infolded or infaulted patches of Permian or other older rocks. With the data now available it is quite impossible to outline these areas.

The paper of Dr. K. Walther, of Montevideo, "Ueber Transgressionen du oberen Gondwana-Formation in Südbrasilien u Uruguay," deals with the geologic history of the State of Rio Grande do Sul and is altogether one of the best papers on the geology of that state.

On the geological map the coastal deposits in Rio Grande do Sul are put down as Quaternary. It is highly probable that some of these deposits are Pliocene, but thus far the paleontologic evidence of their Pliocene age is lacking.

The chief publications on the coal of the state are those of Bem, Cabral, Dahne, Frank, Ginty, Graça, Hull, Lange, Lyon, Parigot, Plant, Pederneiras, Primavera, Thornton, and I. C. White.

Papers on the gold and copper deposits are those of Eddy, Gorceix, Groddeck, Netto, and Walther.

The principal authors who have written on the paleontology of the state are Carruthers, Seward, White (David), Woodward, and Zeiller.

General geology.-Tertiary and Quaternary sediments, inclosing Lagoa dos Patos and Lagoa Merim, form a belt along the coast and lap back against the Archean area. To the landward of this belt lies an area of Archean rocks with here and there outliers of Triassic rocks, and of Lower Permian rocks, in which coal is found. The high land in the northern and western parts of the state is mostly pre-Cretaceous trap resting directly on Triassic beds.

These geologic divisions correspond fairly well with the broad topographic features of the state. The Archean rocks are charactiristic granites, gneisses, and schists. There are probably some of the older Paleozoic rocks within the Archean area, but they have never been located in detail.

The oldest rocks in the state from which fossils have been obtained are the Lower Permian in which the coal occurs. The rocks of this series are sandstone, shales, and coal beds, all of them somewhat folà?d.

The Triassic beds are reddish sandstone, approximately horizontal, but broken by many faults, some of them having considerable dislocations. The discovery in these beds of reptilian bones (Scaphonyx fischeri) near Santa Maria da Bocca do Monte, in Rio Grande do Sul, made it possible for Dr. A. Smith Woodward to determine their age satisfactorily.

The eruptive rocks that overlie the Triassic in Rio Grande do Sul are 
part of a great sheet or of a number of flows that are widely exposed over the Brazilian states of Matto Grosso, São Paulo, Paraná, Santa Catharina, Rio Grande do Sul, and over parts of Uruguay, Paraguay, and the Argentine Republic. The rocks are mostly diabase porphyrite, often amygdaloidal. They appear sometimes as dikes and sometimes as sheets whose margins form steep mountain escarpments.

Siemiradski thinks there are faults with large dislocations through the northern part of the state, but as yet they have not been precisely located.

Economic geology.-The chief mineral products of Rio Grande do Sul is coal, which is found only in the Lower Permian areas. Copper and gold have been mined from the older Paleozoic rocks near Lavras, and large quantities of agates that weather from the trap rocks or are shipped from the plateau region south of Passo Fundo. Marble is reported from several places within the area of the crystalline rocks, and zinc is said to occur, but not in workable quantities (Scott). Magnesite is reported from Rio Pardo and from Rio Capivary, where it occurs in Archean rocks, probably in the form of crystalline marble. It is popularly known at these places as pedra moura, marmore amarello, and olho de boi branco. Molybdenum is said to occur with copper at Palmas (Oliveira).

\section{Geologic Maps of Rio Grande do Sul}

Hettner, 1891.-An article on southern Brazil published by Dr. Alfred Hettner in the Zeitschrift der Gesellschaft für Erdkunde zu Berlin, Band XXVI, Berlin, 1891, contains a sketch-map of the general geology of the State of Rio Grande do Sul. It is on a scale of 1 to $7,500,000$ and shows one structural section and five subdivisions of the geology, one of which, the red sandstone, is said to be of undetermined age.

Branner, 1906.-In the first edition of his Geologia Elementar, Rio, 1906, Branner published, at page 238, a sketch-map of the geology of most of Rio Grande do Sul and part of Santa Catharina. The data for it were taken chiefly from Hettner's paper. It is on a scale of 1 to $4,300,000$ and five subdivisions of the geology are shown. The same map is given at page 319 of the second edition of Branner's Geologia Elementar, Rio, 1915.

I. C. White, 1908. - In his final report on the coal measures . . . of south Brazil, Dr. I. C. White gives a map of the State of Parana to show the general distribution of the Permian coal horizon and of the overlying rocks. The distribution of these beds in Rio Grande do Sul is included in the map. Only two geologic divisions are shown, the Tubarão, or coalbearing beds, and the overlying beds, though not in detail. The scale is 
1 to $2,010,365$. The date on the map is $190 \%$, but the report was published at Rio de Janeiro in 1908.

\section{Bibliography of the Geology of Rio Grande do Sul}

Henrique Schutel Ambauer: A provincia do Rio Grande do Sul, descripção e viagens. Revista Trimensal do Instituto Historico, Tomo LI, part II, paginas 25-72. Rio de Janeiro, 1888.

Balthazar Francisco de Bem: Mineração ua Provincia do Rio Grande do Sul. Annexo ao Relatorio do Ministro da Agricultura. 3 paginas. Rio de Janeiro, 1874.

M. Beschoren : Zur Geographie der Provinz Rio Grande do Sul. Zeitschrift der Gesellschaft für Erdkunde zu Berlin, volume XIII, pages 417-431. Berlin, 1878.

Max. Beschoren : Beiträge zur nähern Kenntnis der brasilianischen Provinz São Pedro do Rio Grande do Sul. Ergänzungsheft No. 96 zu Petermann's Mittheilungen. 91 pages. Gotha, 1889.

A. Borcherr : Das Alter der Paraná-Stufe. Centralblatt, 1901, No. 4, 111-113. Stuttgart, 1901.

I. H. BREDEL : Relatorio sobre as jazidas metalliferas de Lavras, provincia do Rio Grande do Sul. Annuario do Estado do Rio Grande do Sul para o anno de 1910, paginas 130-132. Porto Alegre, 1909.

Frederico A. de Vasconcellos A. Peretra Carral: Memoria geologica sobre os terrenos de Curral-Alto e Serro do Roque, na Provincia de São Pedro do Sul. $8^{\circ}$, xiv +162 paginas, geologic map and colored geologic sections. Porto Alegre, 1851.

W. Carruthers: On the plant remains from the Brazilian coal beds, with remarks on the genus Flemingites. Geological Magazine, volume VI, 1869, pages 151-155, plates V-VI. London, 1869.

Dr. Eugenio Dahne: (A bacia carbonifera do Arroio dos Ratos.) Revista de Engenharia No. 219, 14 de Outubro de 1889, volume XI, pagina 234. Rio de Janeiro, 1889.

E. S. Eugento Dahne: A mineração do carvão e as concessões da companhia no Estado do Rio Grande do Sul, Brazil. Porto Alegre, 1893.

Euanio Dahne: Descriptive memorial of the State of Rio Grande do Sul. Porto Alegre, 1904. (Geology and minerals, pages 6-17.)

Henry Endy: On the mines of the Province of Rio Grande do Sul, Brazil. Transactions of the Royal Geological Society of Cornwall, volume X, part $V$, pages 157-160, $8^{\circ}$. Penzance, 1883.

J. B. Fortes: Santa Maria da Bocca do Monte, cidade e municipio. Annuario do Estado do Rio Grande do Sul para o anno de 1902, paginas 155-162. Porto-Alegre, 1901.

Gmanuel Paulo Frank: Minas de carvão de S. Jeronymo, with map of the mines. Revista de Engenharia, No. 219, 14 de Outubro de 1889, volume XI, paginas 220-225. Rio de Janeiro, 1889.

Hentique Gorceix: Noticia sobre a jazida e exploração do ouro em Lavras e em Caçapara, Provincia de São Pedro do Rio Grande do Sul. (Traduzida do francez.) Rio de Janeiro, 1874. $8^{\circ}, 23$ pages. Tambem no Auxiliador 
da Industria Nacional No. 5, Malo de 1878, volume XLVI, paginas 109-114; No. 6, Junho de 1878, paginas 133-137. Rio de Janeiro, 1878.

Henri Gorceix : Notice sur le gisement et l'exploitation de l'or a Lavras, province de Riọ Grande du Sul. Bulletin Société de l'Industrie Mínérale, 2me série, Tome IV, 1875, pages 361-381. Paris, 1875.

E. J. Cordeiro da Graça : Relatoria dos estudos mineralogicos e geologicos da Provincia de São Pedro do Rio Grande do Sul. $8^{\circ}$. Rio de Janeiro, 1883.

Dr. voN GrodDECK : Ueber das Vorkommen von Gold-Kupfer-und Bleierzen in der Provinz Rio Grande do Sul in Brasilien. Berg-und Hütten. Zeitg., December 7,1877 , No. 49 , pages $422-424$.

Dr. C. Guillemain: Lagerstätten in der Republik Uruguay. Beiblatt zur Zeitschrift für Praktische Geologische, September, 1910, volume XVIII, pages 189-192. Berlin, 1910.

Dr. C. GuIllemain : Der erste Versuch einer geologischen Karte von Uruguay. Petermann's Mittheilung, 1910, volume II, page 306.

Dr. C. GuIllemain : Beiträge zur Geologie Uruguays. Neues Jahrbuch für Mineralogie, Geologie und Paleontologie, Beitrage Band XXXIII, pages 208-264. Stuttgart, 1912. (Geological map of Uruguay.)

Dr. R. Hensex : Beiträge zur näheren Kenntniss der brasilianischen Provinz São Pedro do Rio Grande do Sul. Zeitschrift der Gesellschaft für Erdkunde zu Berlin, volume II, pages 227-269, 342-376. Berlin, 1867.

J. Ch. Heusser und G. Claraz: Ein fermerer Beitrag zur Kenntniss des Brasilianischen Küstengebirgs. Vierteljahrschrift der Naturforschenden Gesellschaft in Zurich, volume $X$, pages 60-64. $8^{\circ}$. Zurich, 1865.

ALFRED HeTtaker : Reiseskizzen aus Sudbrasilien. I. Ein Besuch in den deutschen und italienische Colonien bei Porto Alegre in Südbrasilien. Deutsche Rundschau für Gegraphie und Statistik, volume XIV, Heft V, Februar, 1892, pages 193-202; II, Besuch der Kohlenmine von Arroyo dos Ratos und der Colonien Estrella und Santa Cruz, pages 253-261. Wien, 1892.

Dr. AlFred Hertner: Das südlichste Brazilien (Rio Grande do Sul). Zeitschrift der Gesellschaft für Erkunde zu Berlin, volume XXVI, pages 85144. $8^{\circ}$. Berlin, 1891. (Geological maps and section.)

EDWARD HUur: The Brazilian coal flelds. The Quarterly Journal of Sclence, volume I, pages 387-390. London, 1864 .

EDWARD HULL: The Brazilian coal fields. (Note from the Quarterly Journal of Science, No. II, April, 1864.) Appendix $H$ of Brazil and the Brazilians, by Rev. James C. Fletcher and Rev. D. P. Kidder, 9th edition, pages 634637. London, 1879.

H. von Ihering: Die Lagoa dos Patos. Deutsche Geographische Blätter, volume VIII, 193 ff. Bremen, 1885.

ARsène Isaberte: Excursions dans la province de Rio Grande do Sul au Brésil (1834). Extrait d'un voyage inèdit. Nouvelles Annales des Voyages (IJXV), pages 257-279. Paris, 1835. Geologie, page 262 et seq.

Arsène Isabetcle: Voyage a Buenos-Ayres et á Porto Alegre, por la Banda Oriental, les Missions d'Uruguay et la province de Rio Grande do Sul (1830-1834), etc. $8^{\circ}$. Le Havre, 1835. Review: Nouvelles Annales des Voyages, volume IXXIX, pages 235-248. Paris, 1836.

Gustavo Koenteswald: Rio Grande do Sul, 115 pages. São Paulo, 1898. Minerals of Rio Grande do Sul, pages 5-8. 
K. von Koseritz: Die Lagoa dos Patos in Südbrasilien. Globus, 1864, volume VI, page 347 .

J. J. KYLE: On the composition of the rivers Uruguay and Parana. Chemical News, volume XXXVIII, page 28. London, 1878.

Henty Lange: Eine Fahrt nach den Steinkohlengruben von São Jeronymo. Deutsche Rundschau für Geographie, 1883, volume V, page 512.

Hentry Lange: Südbrasilien. Die Provinzen São Pedro do Rio Grande do Sul, Santa Catharina und Parana mit Rücksicht auf die Deutsche Kolonisation. Leipzig, 1885. Mineralien, pages 9, 45, 125-127, 183.

Dr. Henri Lange: Die Flussgebiete des Rio Tubarão und des Rio Ararangua. Petermanns Mittheilungen aus Justus Perthes' Geographischer Anstalt, Band XXXIV, 10-13, 1 Karte. Gotha, 1888.

Max Iron: Description de l'tetat de Rio Grande do Sul (Brésil). Comptes Rendus de la Sociêté Géographie, 1891, pages 515-525. Paris, 1891. Physical features.

E. A. Mannheim: Relatorio sobre algumas condiçzes mineralogicas no estado do Rio Grande do Sul. Correio do Povo, Porto Alegre, 19 de Março de 1908. Republished in Annuario do Estado do Rio Grande do Sul para o anno de 1909, paginas 350-353. Porto Alegre, 1908.

JAMES E. Mrrus: Quaternary deposits and Quaternary or recent elevation of regions and mountains in Brazil, with deductions as to the origin of loess from its observed conditions there. American Geologist, volume III, pages 345-361. Also, separate. Minneapolis, 1889.

JAMES E. Mrlls : Notes upon the surface geology of Rio Grande do Sul, Brazil. American Geologist, volume XXIX, 1902.

Eduardo Jost de Moreas: A via de communicação a Mato Grosso. (Annexo ao Relatorio apresentado á assemblea geral legislativa na 1a sessão da 15a legislatura pelo Ministerio e Secretario de Estado dos Negocios da Agricultura, etc. Rio de Janeiro, 1872. Notas sobre a geologia do Rio Uruguay, page 25 ; sal gemma no valle do Ivahy, pagina 69.

Michaer. G. MdLhatr : Rio Grande do Sul and its German colonies. $8^{\circ}$. London, 1873. Geography and geology, pages 12-22. The coal fields of São Jeronimo, pages 78-84.

Ladislad Netto (Presidente) : Relatorio da Companhia das Minas de Ouro e Cobre do Sul do Brazil, apresentado a Assembléa Geral extraordinaria em 15 de Outubro de $1874,12^{\circ}, 14$ paginas. Rio de Janeiro, 1874.

J. M. Paldaof: O Rio Grande do Sul e a magnesia. Jornal do Commercio de Porto Alegre, Outubro, 1904.

Dr. Julio Parigot: Memoria sobre as minas de carvão de pedra do Brazil. $4^{\circ}, 30$ paginas, with cut. Rio de Janeiro, Villeneuve \& Co., 1841.

Innocencio Velloso Pederneiras: Carvão de pedra e mineraes de ferro da provincia do Rio Grande do Sul. Jornal do Commercio, 17 de Abril de 1848. Rio de Janeíro, 1848. Copiado no Relatorio dos Estudos de João Cordeiro da Graç, q. v. (volumes X-XV).

Josfe Feliciano Franandes Pinheiro, Visconde de $S$. Leopoldo: Annaes da Provincia de S. Pedro. Segunda edição, $8^{\circ}$. Paris, Na Typographia de Casimir, 1839. Topography and geology, chapter I, pages 15-41.

Joh.s Plant: On the discovery of coal in Brazil. Transactions of the Manchester Geological Society, volume IV, No. 12, pages 294-304. Manchester. 
1864. Also, The Mining and Smelting Magazine, volume V, March, 1864, pages 148-151. London, 1864.

Nathaniel Plant: The Brazilian coal fields. Geological Magazine, volume VI, April, 1869, pages 147-150. Separate, pages 1-4.

Nathaniel Plant: The coal fields of the River Jaguarão and its tributaries, the rivers Candiota and Jaguarão-Chico, in the Province of Rio Grande do Sul. Appendix $\mathrm{B}$ of Brazil and the Brazilians, by Rev. James C. Fletcher and Rev. D. P. Kidder. Ninth edition, pages 933-935. London, 1879.

P. B. Primaveira : (Relatorio sobre as minas de carvão do Rio Grande do Sul, ao Presidente da Provincia, pelo Inspector das Minas.) Publicado no Diccionario Geographico das Miuas do Brasil, por Francisco Ignacio Ferreira, a paginas 459-466. Rio de Janeiro, 1885.

Gaspar Rechsteiner: Carvão de pedra (do Rio Grande do Sul). Carta ao Presidente da Provincia sobre a qualidade e quantidade. Auxiliador da Industria Nacional, No. 11, volume L, Novembro de 1882, paginas 255-256. Rio de Janeiro, 1882.

Woldemar Schultz: Studien über agrarische und physikalische Verhä]tnisse in Sïdbrasilien. Mit einem atlas. 244 pages. Leipzig, 1865. (Pages 209224 contain a Beilage on Mineralogy by Gustav Jenzsch. The atlas has geologic sections.)

A. ScHUPP : Geologia da Lagoa dos Patos. Annuario do Estado do Rio Grande do Sul para o anno de 1900, pagina 173. Porto Alęgre, 1899. (Fossil oysters found at the entrance of Barra do Ribeiro.)

F. Ambrosio Schupp: Uma contribuição para a geologia do Rio Grande do Sul. Annuario do Estado do Rio Grande do Sul. Para o anno de 1905, paginas 311-320. Porto Alegre, 1904.

H. KILbURN ScotT: The mineral resources of the State of Rio Grande do Sul, Brazil. Transactions of the Institute of Mining Engineers, volume XXV, pages 510-528. London and Neweastle-upon-Tyne, 1903.

A. C. Seward : Floras of the past; their composition and distribution. Nature, October 8, 1903, pages 556-568. London; 1903. (Permo-Carboniferous flora of southern Brazil.)

Jos. v. SIEMTradzKI: Geologische Reisebeobachtungen in Sïdbrasilien. Sitz. Ber. Akad. Wiss., Mat.-nat. Cl., Bd. 107, Abt. I, pages 23-39. I Taf., 1 figure. Wien, 1898.

Francisco R. Simch: A formação geologica de Porto Alegre (Rio Grande do Sul). Publicado no jornal A Federação, Porto Alegre, Brazil, 12 de Abril (No. 86), 14 de Abril (No. 87), 16 de Abril (No. 89), 18 de Abril (No. 91), 26 de Abril (No. 97), 29 de Abril (No. 99) de 1902.

F. Rob. Simcr: Mineraes do Rio Grande do Sul. Annuario do Estado do Rio Grande do Sul de 1911, paginas 177-188. Porto Alegre, 1910.

HerberT H. Smith : Geologia do Rio Grande do Sul. Annuario do Estado do Rio Grande do Sul para o anno de 1901. Publicado sobre a direção de Graciano A. de Azambuja. 12 ${ }^{\circ}$, paginas 113-122. Porto Alegre, 1900. Compilation from Smith's paper on "The Naturalist Brazilian Expedition," in the American Naturalist, $1883,1884, q . v$.

KARL WaLTHER: Zur Geologie der Gegend von Seibal und ihrer Kupfererzlagerstätten im Staate Rio Granđe do Sul. Zeitschrift für Praktische. Geologie XX, Heft 10, page 404. Berlin, Oktober, 1912. 
KarL WaLther: Ueber Transgressionen der oberen "Gondwana-Formation" in Südbrasilien und Uruguay. Centralblatt für Mineralogie, Geologie, und Paläontologie 1912, No. 13, pages 398-405. Stuttgart, Juli, 1912.

K. Walther : La edad geologica de las areniscas brasilano-uruguayas, llamadas de "São Bento." Revista del Ministerio de Industrias, Año I, No. 6, paginas 17-23. Montevideo, 1913.

WeIss : Ueber das südliche Ende des Gebirgszuges von Brazilien in der Provinz São Pedro do Sul und der Banda Oriental oder dem Staate von Montevideo; nach den Sammlungen des Herrn Fr. Sellow, von Hrn. Weiss. Acad. der Wissenschaften Phys. Klasse, 1827 (Berlin), 1828.

David WhITE : Permo-carboniferous changes in Brazilian South America, indicated by fossil plants. Science, volume XXV, May 17, 1907, page 772.

DAvid WHIte: Report on the fossil flora of the Coal Measures of Brazil. Appendix of I. C. White's report on the Coal Measures of South Brazil. Rio de Janeiro, 1908.

I. C. WhiTE : Report on the Coal Measures and associated rocks of South Brazil. In English and Portuguese. Report to the Minister of Industry, etc. $4^{\circ}$, illustrated, xxviii +617 pages. Rio de Janeiro, 1908.

A. Sмitr Woodward: On some fossil reptilian bones from the State of Rio Grande do Sul, Brazil. Geological Magazine, June, 1908, pages 251-255, illustrated. Same in Revista do Museu Paulista, volume VII, pages 46-57.

A. SMITH Woodward: On some Dinosaurian bones from South Brazil. Geological Magazine, volume X, page 512. London, November, 1903. (Traces of Gondwanaland fauna from the red beds of Rio Grande do Sul.)

R. ZeILLER: Sur quelques empreintes vegetales des gisements houillers du Brésil meridional. Comptes Rendus de l'Academie des Sciences, volume CXXI, pages 961-964. Paris, 1895.

R. ZeILleR: Note sur la flore fossile des gisements houillers de Rio Grande do Sul. Bulletin Société Géologique de France, third series, volume XXIII, pages 601-629 (3 plates). Paris, 1895.

R. Zmincer: Sur un Lepidodendron silicifié du Brésil. Comptes Rendus de l'Academie des Sciences, volume CXXVII, pages 245-247. Paris, 1898.

\section{SANTA CATHARINA}

Previous investigations.-Only the eastern half of the State of Santa Catharina has had its geology described. .The few papers that treat of its geology confine themselves chiefly to the coal deposits on Rio Tubarão. The most important of these are the publications of Dr. Gonzaga de Campos, of Dr. I. C. White, of Parigot, of E. Dahne, and of Thornton. The works that are most enlightening of all in regard to the geology outside of the coal region are the papers of Dr. J. B. Woodworth and of Euzebio Paulo de Oliveira. Carl Ballod's Der Staat Santa Catharina, in Südbrasilien, also has some helpful notes on the geology.

A meteorite found on the island of São Francisco, in Santa Catharina, has attracted considerable attention among mineralogists. It has been written on by Becquerel, Gonzaga de Campos, Derby, J. L. Smith, Guignet, Calogeras, Damour, Daubrée, Lunay, Meunier. 
General geology.-Archean rocks form a belt lying between the ocean and the crest of the Serra do Mar. Except in the north, however, the Archean rocks do not rise quite to the tops of the mountains, but end on their eastern flanks. Resting on the granites are the Lower Permian beds, in which coal is found west of Tubarão. Glacial action in Permian times is shown by these beds near Rio Negro. On top of the Lower Permian are the Upper Permian, on top of which are the Botucatú Triassic sandstones, followed next by sheets and dikes of trap (diabase porphyrite). All of these sediments and the accompanying trap sheets have a general and gentle westward dip, while the traps cover nearly all of the western half of the state.

Economic geology.-The chief mineral resources of Santa Catharina are coal from the mines in the Lower Permian about Minas and the agates found in the areas of the eruptive rocks. Bituminous shales are abundant in the Permian, marble is found in the Archean area, and lead and copper are reported by Dr. Francisco de Paula Oliveira.

\section{Geologic Map of Santa Catharina}

I. C. White, 1908.-The only geologic map of Santa Catharina known to the writer is the one given by Dr. I. C. White as part of a map of the States in which coal is found. The scale of the map is 1 to $2,010,365$; only two divisions are shown and these not in detail, the Tubarão or Permian coal horizon and the rocks above it. The map is dated 190\%, but the report was published at Rio in 1908.

\section{Bibliography of the Geology of Santa Catharina}

Carl Ballod: Der Staat Santa Catharina. Ausland, 1892, pages 27-31. Stutt. gart, 1892.

F. BURLAMAQUI : Noticia sobre alguns mineraes e rochas de varias provincias do Brazil, recebidas no Museu Nacional durante os annos de 1856, 1857 e 1858. Revista Brazileira, volume II, paginas 241-265. Map of Santa Catharine coal fields. Rio de Janeiro, 1856-58.

L. F. Gonzaga de Campos: Nota sobre a localidade do ferro nativo de Santa Catharina. Meteoritos Brasileiros. Révista do Observatorio, volume III, No. 5, paginas 65-68. Rio de Janeiro, 1888. Abstract: Neues Jahrbuch für Mineralogie, 1891, volume I, pagina 243. Referate.

Luiz Gonzaqa de Campos: Minas de carvão do Tubarão, Santa Catharina, 49 paginas com mappas e perfis. $4^{\circ}$. Rio de Janeiro, 1890. E' a segunda parte do Relatorio apresentado ao Exm. Sr. General Francisco Glicerio, Ministro da Agricultura, etc., pelos Engenheiros F. Hostilio de Moraes Rego, Luiz Gonzaga de Campos e João Caldeira de Alvarenga Messeder, paginas 27-76. 
Euaenio Dahne: A tormação carbonifera em Tubarão, Santa Catharina. Publicado no jornal "A Federação," Porto Alegre, anno XXI, No. 39, 16 de Fevereiro de 1904.

Henay Lange: Südbrasilien. Die Provinzen Săo Pedro do Rlo Grande do Sul, Santa Catharina und Paraná. Leipzig, 1885. Mineralien, pages 9,.45, 125-127, 183.

Dr. Henri lange: Die Flussgebiete des Rio Tubarão und des Rio Ararangua. Petermanns Mittheilungen aus Justus Perthes' Geographischer Anstalt, Band XXXIV, pages 10-13. Gotha, 1888.

Eduardo Joste de Moraes: A via de communicação a Mato Grosso. Memoria apresentada a consideração do governo Imperial. (Annexo ao Relatorio apresentado a assemblea geral legislativa na 1a sessão da 15a legislatura pelo Ministro e Secretario de Estado dos Negocios da Agricultura, etc.) $4^{\circ}$. Rio de Janeiro, 1872. Notas sobre a geologia do Rio Uruguay, 25; sal gemma no valle do Ivahy, pagina 69.

ĹUzerio Paulo de OrJverra : Geologia do Estado do Parana. Boletim do Ministerio da Agrieultura, Industria e Commercio, Anno V, No. 1, paginas 67143. Rio de Janeiro, 1916. (This article does not have the author's name.)

Dr. Julio Parigot: Minas de carvão de pedra de Santa Catharina. $8^{\circ}, 12$ paginas. Rio de Janeiro, 1841.

Dr. Jutio Parigot: Memoria terceira sobre as minas de carvão de pedra de Santa Catharina. $4^{\circ}, 30$ paginas. Rio de Janeiro, 1842.

Nathaniel Plant: The Brazilian coal fields. Geological Magazine, volume VI, April, 1869, pages 147-150.

Wordemar SchULTz: Studien über agrarische und physikalische Verhältnisse in Südbrasilien. 224 pages. Leipzig, 1865. (Pages 209-224 contain a Beilage on Mineralogy by Gustar Jenzsch. The atlas has geologic sections.)

Edward Thornton: Report on the existence of a large coal-field in the province of St. Catherine's, Brazil. Quarterly Journal of the Geological Society, June, 1867, pages 386-387. London, 1867.

Edward Thornton: . . . Coal fields in the province of Saint Catharine. Reports received from Her Majesty's secretaries of embassy and legation respecting coal, in continuation of papers presented in 1867. Parliamentary Papers, pages 7-8. $4^{\circ}$. London, 1868.

Charles Van Lede: De la Colonisation au Brésil. Mémoire historique, descriptif, statistique et commercial sur la Province de Sainte-Catherine, $427+$ vill paginas, $8^{\circ}$. Bruxelles, 1843. On geology, chapter IV, pages 94-125; alsó Diario do Rio de Janeiro, No. 6525, 15 de Janeiro de 1844. Given in Portuguese in the appendix to Boubée's "Geologia Elementar," paginas 43-50. Jazigo do carvão de pedra de Santa Catharina : Extracto Caput $\mathbf{X}$, op. cit., additamento, paginas 51-58. Rio de Janeiro, Typ. Nacional, 1846.

Carlos Van Lede: Geologia da Provincia de Santa Catharina. Artigo extrahido da Memoria Historica, Estatistica e Commercial . . . sobre a Provincia de Santa Catharina, e vertido em vulgar pelo Dr. A. M. de Miranda Castro. Revista Trimensal do Instituto Historico, volume VII, paginas 87-93, 178-195. 2a edição. Rio de Janeiro (2a edição, 1866), 1845. 
L. Wagongr: Parana e Santa Catharina. Revista Industrial, Janeiro de 1878, volume II, pages 9-10. New York, 1878. (Notes on geology and physical features.)

I. C. WHITE: Report on the Coal Measures and associated rocks of South Brazil.. In English and Portuguese. Report to the.Minister of Industry, etc., xxviii +617 pages, $4^{\circ}$, illustrated. Rio de Janeiro, 1908.

J. B. Woopworth : Geological expedition to Brazil and Chile, 1908-1909. Bulletin of the Museum of Comparative Zoology, volume LVI, No. 1, 135 pages and 37 plates. Cambridge, November, 1912.

\section{SÃO PAULO}

Previous investigations.-The base map used for the State of São Paulo was the one issued in 1912 by the Commissão Geographica e Geologica de São Paulo.

More geologic work has been done in São Paulo than in any other one Brazilian state. As yet, however, no general description of the geology of the state has been published. Mr. Derby, who was state geologist from 1886 to 1904 , published many special papers on the geology of the state, the most important of which are mentioned below. The survey (officially called the Commissão Geographica e Geologica de São Paulo) has published five topographic sheets in preliminary editions (Jundiahy, Campinas, São Roque, Rio Claro, Ytú), but only parts of the areas are geologically mapped, while by some unfortunate oversight the names of the geologists who did the work are not given. Several large folios have been issued, but they are devoted to the explorations of some of the larger streams of the state-the Tieté, Feio, Aguapehy, and Rio Grande. These folios are fully illustrated by beautiful photographs. A few of them contain short papers with notes on the geology, but the publications are too unwieldly to be: used in the field. One by Dr. Florence, on Rio Grande, is especially valuable on that region, and the paper by Pacheco, on the fossils found in the Baurú beds, is of great value as determining the age of that formation. The geology along the Paranapanema is described by Dr. Francisco de. Paula Oliveira in a bulletin published by the survey:

Two papers by Dr. Gonzaga de Campos are especially valuable contributions; they are (1) Baurú e Itapurú, and (2) Relatorio sobre o Rio Tieté.

The iron deposits of the state are described by Derby:; the Permian glacial deposits are briefly described by J. B. Woodworth, and the fossils are described by Cope, Geinitz, Pacheco, Renault, Von Thering, and Woodward.

General geology.-Over the eastern and southeastern parts of the State of São Paulo are exposed the Ari'ean rocks which form the Serra do 


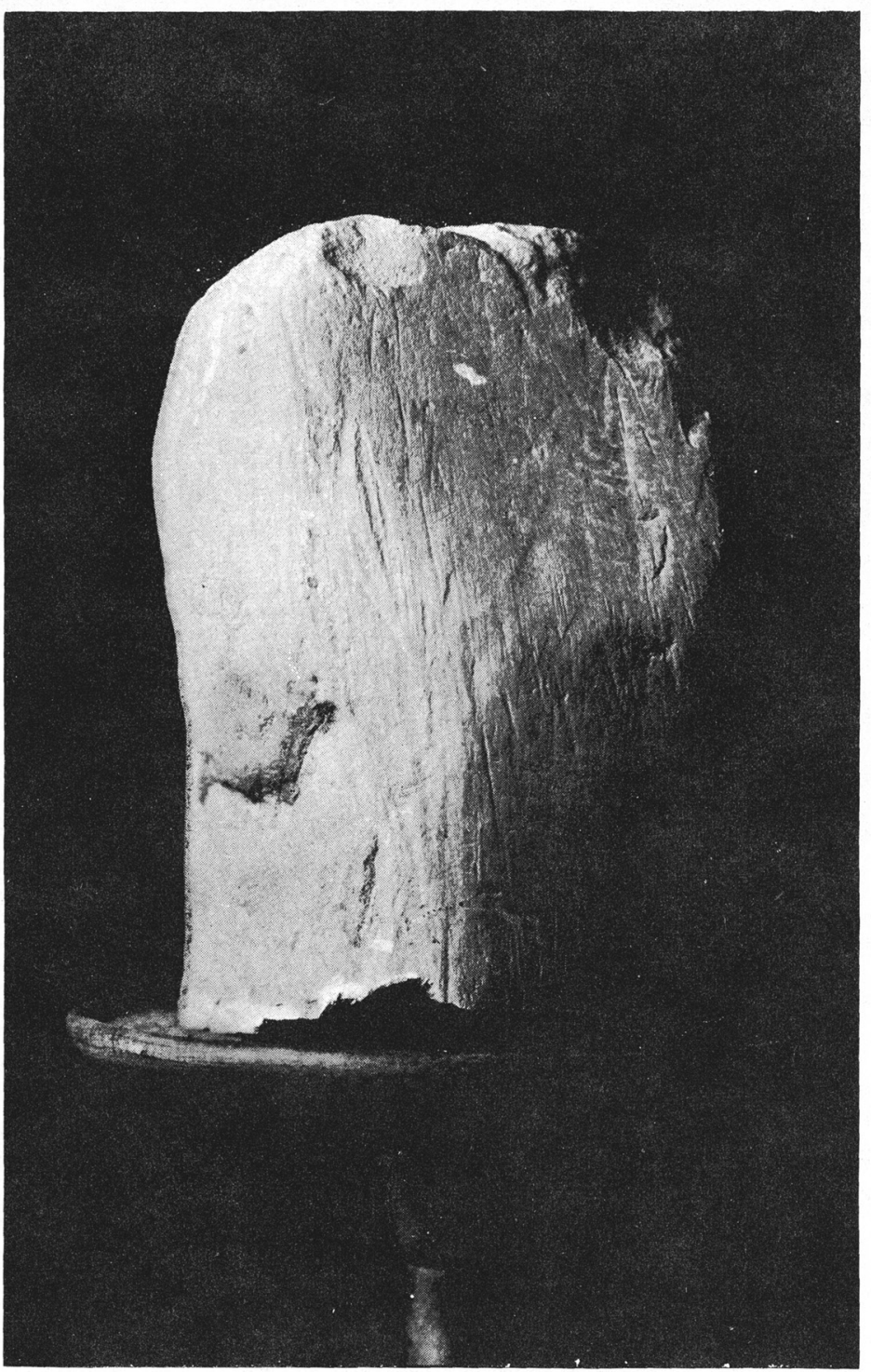

STRIATED BOULDER OF QUARTZITE FROM THE PERMIAN BEDS NEAR MOCOCA, STATE OF SAO PAULO

Size, 7.5 by 5 centimeters. Commissão Geologica de São Paulo. 


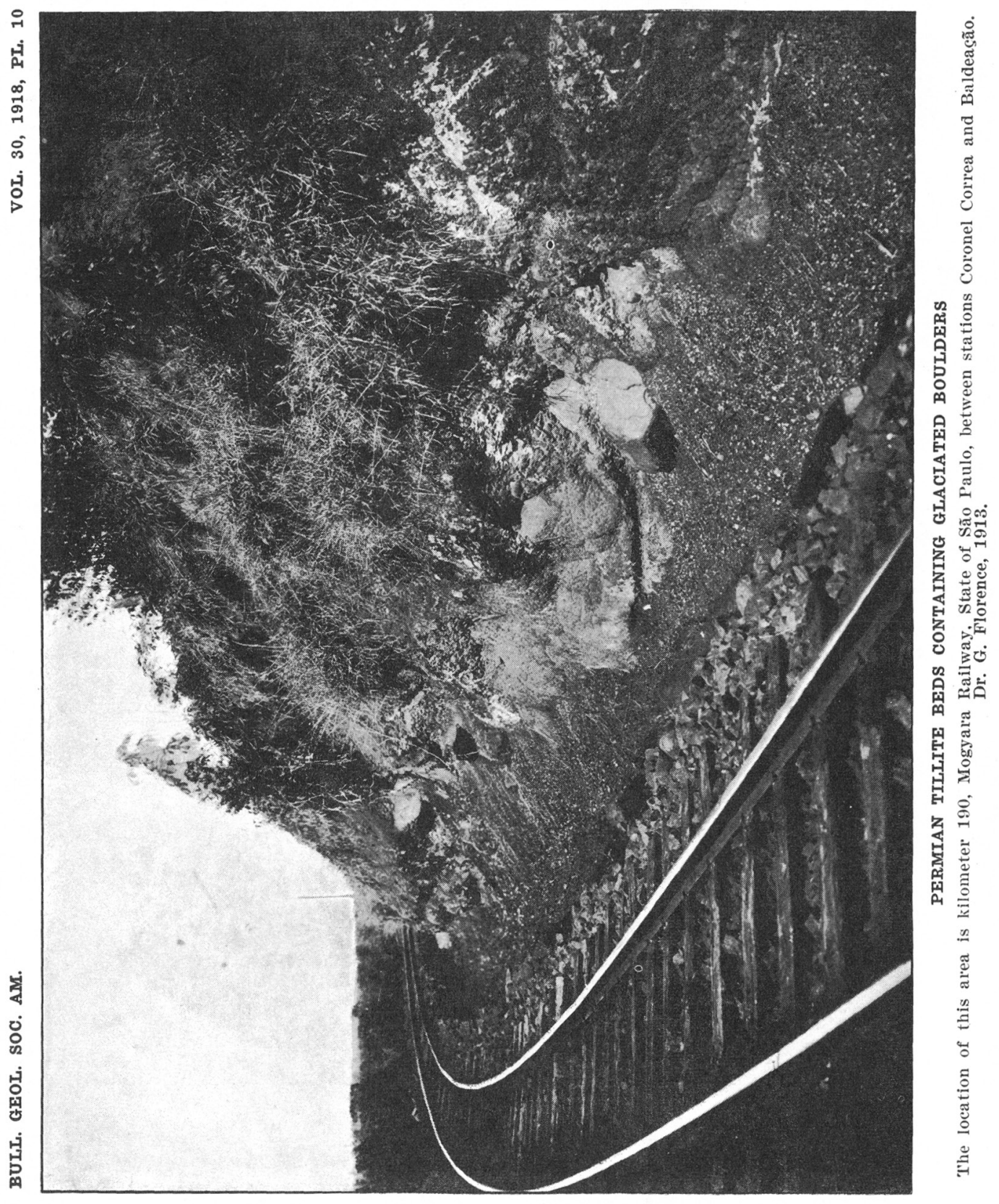


Mar and pass over the divide and extend westward to the base of the Lower Permian sediments. In the southwest corner of the state $a$ small exposure (70 kilometers long) of Devonian rocks rests against the Archean and dips gently toward the northwest. On top of the Devonian rocks are Lower Permian beds-sandstones and shales-which rest on the Archean from near Faxina to the Minas frontier just north of Mococa, São Paulo. These Lower Permian beds contain well marked evidences of glaciation. The next higher beds are the Upper Permian, which contain the fossils Stereosternum and Mesosaurus and characteristic siliceous concretions and beds. The Permian beds are followed by the Triassic red beds called the Botucatú. They form the mass of the Serra de Botucatú and extend southwestward into the State of Paraná and northward to and beyond Rifaina, where they cross into the State of Minas. Still farther west, and forming the highlands of a large part of the state, are the Baurú beds, which are Lower Cretaceous. These sedimentary beds dip gently toward the northwest. All beds below the Baurú (Cretaceous) are cut by eruptive dikes, and the Triassic sediments are interbedded with sheets of lava. In showing the areas of the eruptive rock on the São Paulo part of the geologic map no attempt is made to give the details of the areas, partly because the areas have not been outlined- and partly because the scale of the map does not admit of such details. The red lands of São Paulo, famous for their fertility, are formed by the decomposition of the eruptive rocks, and the areas of the red lands are really much larger than the map might lead one to suppose.

From 30 kilometers west of the city of São Paulo and following down the Rio Parahyba to Bocaina, there are bituminous shales and sandstones marking the sites of Tertiary lakes within the Archean area.

Economic geology.-The mineral resources of São Paulo now known are iron, marble, bituminous shales, building stones, limestones, and ceramic clays.

The first iron manufactured in Brazil, and probably the first made in America, was produced about the year 1600, at Ipanema, in the State of São Paulo. The manufacture of iron at that place was not kept up, and though it was attempted several times afterwards, it has thus far never been commercially successful. ${ }^{81}$ The Ipanema iron ores are in an isolated Archean area, a little more than a hundred kilometers west of the city of São Paulo.

The bituminous shales at the base of the Upper Permian are exposed at many places in São Paulo and could easily be located along nearly all

\footnotetext{
s1 Leandro Dupre : Memoria sobre a fabrica de ferro de săo João de Ipanema. Annaes da Escola de Minas, no. 4, pp. 49-90. Rio, 1885.
} 
of the outcrop of those beds. So far as I can learn, they have not been utilized. These shales have been regarded as evidences of the existence of petroleum, and wells have been sunk in search of it, but thus far without success. The bituminous shales of the Tertiary lake deposits, however, have been used at Taubaté for the manufacture of gas. They contain about 7 per cent of petrolene.

Marbles occur in large quantities at certain places in the Archean areas of the state, notably in the region about the headwaters of the rios Iporanga and Bethary west, northwest, and north of Villa Iporanga, and at Pantojo west of São Roque and south of Sorocaba, where there are extensive quarries. There are also limestones in the Permian areas, notably at Limeira, Itapetininga, and, in addition to the marbles mentioned, building stones of many kinds are abundant and of excellent qualities.

Clays for the manufacture of bricks, tiles, and drain and sewer pipes are especially abundant in the Tertiary areas of the state.

\section{Geologic Maps of São Paulo}

Pissis, 1842.-Accompanying Pissis' "Mémoire sur la position géologique des terraines de la partie australe du Brésil," published by the French Academy in 1842, is a geologic map that includes the eastern part of the State of São Paulo as far west as Piracicaba. The scale is 1 to 2,500,000 and ten divisions are shown, one of which is the Tertiary lake basins of that state.

Derby, 1885.-An outline of the geology of eastern São Paulo by 0. A. Derby is given in a map accompanying C. F. Van Delden Laerne's "Le Brésil et Java; Rapport sur la culture du café en Amérique, Asie et Afrique. La Haye, 1885." The map bears the date 1884 ; it is on a scale of 1 to $1,000,000$ and shows six geologic divisions.

The same map, with a few additions, was reproduced in Branner's Geologia Elementar, at page 230 of the first edition, 1906, and at page 320 of the second edition, 1915. The scale of the reproduction is about 1 to 5,000,000 and five geologic divisions are shown.

\section{Bibliography of the Geology of São Paulo}

W. Garderwood: (Coal at Taubaté, São Paulo.) Chemiker Zeitung, volume XVIII, page 89. Göthen, January 20, 1894.

Gonzaga de Campos: Relatorio . . . da Commissão Geographica e Geologica de São Paulo, paginas 22-34. São Paulo, 1889.

Gonzaga de Campos: Relatorlo sobre o Rio Tieté. São Paulo, 1905.

Gonzaga de Campos: Reconhecimento da zona comprehendida entre Baura e Itapura. São Paulo, 1905. 
L, F. Gonzaga de Campos: Estrada de Ferro de Araraquara, Prolongamento de Ribeirãosinho a São José do Rio Pardo, Estudos Geraes, pagina 52, São Paulo, 1901.

LUiz F. Gonzaga de Gampos: Empreza de Mineração no Municiplo de Apiahy (São Paulo). . . . Relatorio dos trabalhos effectuados no decı rso dos mezes de Junho de 1882 a Janeiro de 1883. 59 pages. São Paulo, 1900.

João Pedro Cardoso: Relatorio da Commissão Geographica e Geologica do Estado de São Paulo para o anno de 1906. São Paulo, 1907.

E. D. Cope: The Carboniferous genus Stereosternum. American Naturalist, December, 1887, volume XXI, page 1109. Philadelphia, 1887.

M. Pio Correa : Littoral sul-Paulista. Notas scientificas. Boletim do Min. da Industria, Viação e Obras Publicas. 1 anno, No. 2, 1909; Tomo II, pages 141-150. Rio de Janeiro, 1909.

O. A. DerbY : Calcareos hydraulicos de São Paulo. Revista de Engenharia, 28 de Maio de 1884, volume VI, paginas 116-117. Rio de Janeiro, 1884.

O. A. Derby : Fosseis de São Paulo. Revista de Engenharia, 28 de Outubro de 1884, volume VI, pages $233-234$.

o. A. Derby : Terrenos carboniferos das provincias de São Paulo e Paraná. Revista de Engenharia, 28 de Agosto de 1883, volume V, paginas 228-229. Extrahido do Jornal do Commercio do Rio de Janeiro. Rio, 1883. Also, in the Auxiliador da Industria Nacional, No. 11, Novembro de 1883, paginas 258-260. Rio de Janeiro, 1883.

O. A. Derby : Retrospecto historico dos trabalhos geographicos e geologicos effectuados na Provincia de São Paulo. Boletim No. 1 da Commissão Geographica e Geologica da Provincia de São Paulo. 26 paginas, $8^{\circ}$. São Paulo, 1889.

o. A. Derby : Relatorio da Commissão Geographica e Geologica da Provincia de São Paulo, paginas 5-42. São Paulo, 1889.

O. A. Derry : On the magnetite ore districts of Jacupiranga and Ipanema, São Paulo, Brazil. American Journal of Science, volume XLI, pages 311-321. New Haven, 1891.

G. Florence: Notas geologicas sobre o Rio Paraná. Commissão Geographica e Geologica de São Paulo, folio, paginas 7-8. São Paulo, 1906.

G. Ftorence : Notas geologicas sobre o Rio Tieté. Commissão Geographica e Geologica de São Paulo, folio, paginas 9-15. São Paulo, 1907.

G. Flonence: Notas geologicas sobre o Rio Grande. Commissão Geographica e Geologica de São Paulo, paginas 29-32. São Paulo, 1913.

H. B. Gernitz: Uebereinige Eruptivgesteine in der Provinz São Paulo in Brasilien. Abh. Naturwis. G. Isis, pages 31-34. Dresden, 1890.

H. B. Geinitz: Sur Stereosternum tumidum, Cope, du Musée Royal de Minêralogie de Dresde. Annales de la Société Géologique de Belgique, XXV bis, pagès 35-42. Liége, 1900 .

F. Hussak : Notas petrographlcas sobre os augito-porphyritos do Paranapanema. Boletim No. 2, da Commissão Geographica e Geologica da Provincia de São Paulo, paginas 35-39. $\mathbf{8}^{\circ}$. São Paulo, 1889.

E. Hussak : Contribuições Mineralogicas e Petrographicas. I. Notas sobre zeolitas do Augito-Porphyrito de São Paulo e Santa Catharina. Boletim da Commissão Geographica e Geologica do Estado de São Paulo, No. 7, paginas 3-40. II. Estudo de um cascalbo aurifero virgem do Valle da 
Ribeira. III. Pseudo-crystaes de leucita em phonolito (tinguaito) da Serra do Tingua. IV. Interessante endomorphose por acção de contacto de augito-porphyrito com grez; Rio Tieté, Estado de São Paulo. V. Phyllitas e com magnetita do Estado de São Paulo. VI. Noticia resumida sobre a occurrencia de corindon em São Paulo. São Paulo, 1890.

Ur. H. von IHERTNa: Observações sobre os peixes fosseis de Taubaté. Revista do Museu Paulista, volume III, paginas 71-75. São Paulo, 1898.

H. von IHRRINa: A Ilha de São Sebastião. Revista do Museu Paulista, volume II, Geologia, pagina 145-148. São Paulo, 1897.

R. von Imering: Os fosseis de São José do Rio Preto, Estado de São Paulo. Revista do Museu Paulista, volume VIII, paginas 141-146. São Paulo, 1911. (Dinosaur tooth.)

Rioardo KroNe: As grutas calcareas de Iporanga. Revista do Museu Paulista, volume III, paginas 477-500. Săo Paulo, 1898. And Archivos do Mused Nacional, volume XV. Rio de Janeiro, 1909.

HDMUNdo KRưG: A ribeira de Iguape. São Paulo, 1908.

C. F. TAN DeLden LaËrne: Brazil and Java. Report on coffee culture, etc. London, 1885. (Geology, pages 12-26, and geological map of the coffee region.)

Julio B. Lima, Jr.: Relatorio. Exploração dos Rios Feio e Aguapehy. Commissão Geographica e Geologica de São Paulo, paginas 13-14. São Paulo, 1906.

Miguet Arrojado R. Lisboa: Oeste de São Paulo, e sul de Matto Grosso. Geologia, industria mineral, etc. Relatorio da Commissão E. Schnoor. Rio de Janeiro, 1909.

K. NeUmanN : Notizen tiber das Küstenland der brasilianischen Provinzen Paraná und São Paulo. Zeitschrift für allgemeine Erdkunde, N. F. IX, paginas 327-333. Berlin, 1860.

Francrsco de Paula Oltveira: Reconhecimento geologico do Valle do Rio Paranapanema. Boletim Commissão Geographica e. Geologica No. 2, paginas 3-31. São Paulo, 1889.

Joviano A. D'AM. Pacheco: Geologia do Valle do Rio Grande. Commissão Geographica e Geologica de São Paulo, paginas 33-38. São Paulo, 1913.

Cardos Rath: Fragmentos geologicos e geographicos, etc., para a parte physica . . . das provincias de São Paulo e Parana. São Paulo, 1856.

B. Renault: Sur une nouvelle Lycopodiacée houillere (Lycopolopsis derbeyi). Note de M. B. Renault, presenté par M. Duchartre. Compte Rendus de l'Academie des Sclences, volume CX, 1890, pages 809-811. Paris, 1890. (Fossil plants from Piracicaba, São Paulo.)

B. Renault: Note sur une Lycopodiacée arborescente du terrain houiller du Brésil. Bulletin Société Histoire Natural d'Autun, Tome III, pages 109124, plate IX.

B. Renault: (Nota sobre fosseis carboniferos ou permianos de Piracicaba, São Paulo.) Revista de Engenharia, No. 235, 14 de Junho de 1890, volume XII, pagina 134. Rio de Janeiro, 1890.

T'heodono Sampato: Campos de Jordão na serra de Mantiqueira. 28 paginas. São Paulo, 1893.

SpIx und Martius: Reise in Brasillen, volume I, pages 179-289. München, 1823. 
Arthur SMTth WoodWard: On a netw specimen of the Mesosaurian reptile, Stereosternum tumidum, from São Paulo, Brazil. Geological Magazine, April, pages 145-147, 1 plate. London, 1897.

A. SMTrr WoodWARD : Considerações sobre alguns peixes Terciarios dos schistos de Taubaté, Estado de São Paulo, Brazil. Revista do Museu Paulista, volume III, $8^{\circ}$, paginas 63-75. São Paulo, 1898.

A. Smrth Woodward: On a tooth of a Triassic Dinosaur from São Paulo, Brazil. Report of the British Association for the Advancement of Science for 1909 , page 483,1910 .

J. B. WoodworTH : Geological expedition to Brazil and Chile-1908-1909. Bulletin of the Museum of Comparative Zoology, volume LVI, number 1, $8^{\circ}$, illustrated, 135 pages. Cambridge, Massachusetts.

R. ZerLrer: Sur un Lepidodendron silicifié du Brésil. Comptes Rendus de l'Academie des Sciences, volume CXXVII, pages 245-247. Paris, 1898.

\section{SERGIPE}

Previous investigations.-Hartt's Geology and Physical Geography of Brazil contains the first valuable notes on the geology of the State of Sergipe. The general geology of the state was described later in Branner's paper on the geology of the Sergipe-Alagôas basin. That paper was translated into Portuguese and published at Aracajú in 1899. The last important contribution is that of R. H. Soper, whose report is mentioned. in the accompanying bibliography. Our knowledge of the geology of that state was also contributed to by Roderic Crandall, who, as my assistant, first outlined the geology of the interior of the state in 1908.

Cretaceous fossils are abundant in the State of Sergipe. The paleontology of the state is described in Dr. Chas. A. White's important "Contributions to the Paleontology of Brazil," published as volume VII of the archives of the Museu Nacional of Rio de Janeiro in 188\%.

General geology.-Though Sergipe is a small state, its geology is remarkably comprehensive, and, on account of the accessibility of the rocks and their fossils, it affords the key to the geology of a large part of Brazil. The sequence of the rocks may be seen in the Serra Itabaiana and its prolongations, from the Archean area about the village of Itabaiana to the Tertiary beds near the seacoast. The ages of all of the rocks have not yet been determined with certainty, but it is known that they include representatives of Archean, Paleozoic, Mesozoic, and Cenozoic beds, some of them known to be fossiliferous. The Archean area of the state lies along the Rio São Francisco from just above Penedo to above the falls of Paulo Affonso. The Serra Itabaiana is a monoclinal ridge of quartzites resting on the Archean rocks and dipping eastward toward the ocean. Above the quartzites are limestones, shales, and sandstones that continue up into and through the Upper Cretaceous. Still higher horizontal sedi- 


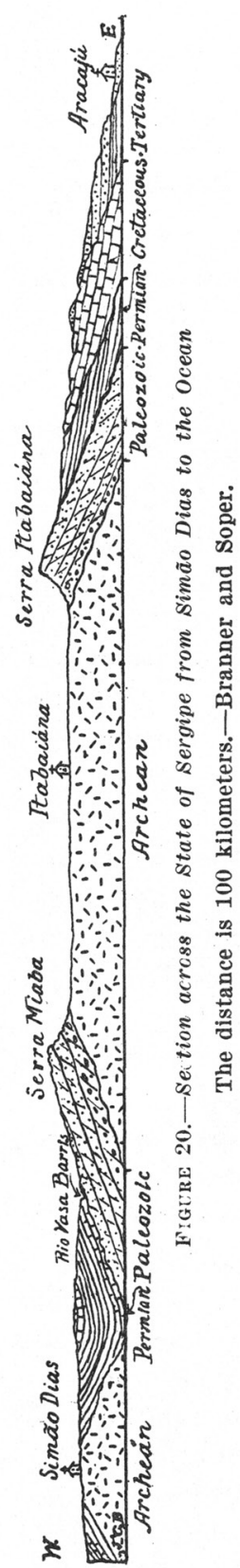

ments near the coast are Tertiary. West of the Serra Miaba is an area of limestones and shales; the Cretaceous series about Maroim and Larangeiras also contains large areas of limestones.

Economic geology.-The limestones and clays of the state are very abundant, are available for the manufacture of Portland cement as well as for ordinary lime, and the oolitic limestones on Rio Sergipe would make excellent building stones. At present those rocks are not used save for the manufacture of small quantities of lime for local consumption. The cream-colored flaggy limestones exposed along Rio Cotinguiba at Sapucary have long been used locally for foundations and for walls and street pavements.

\section{Geologic Maps of Sergipe}

Branner, 1913.-An article by Branner on the Estancia beds of Bahia, Sergipe, and Alagoas, published in the American Journal of Science, volume 35, for June, 1913, page 619 , was accompanied by a small map showing the geology of the southwestern part of the State of Sergipe. It is on a scale of 1 to $2,500,000$ and shows three subdivisions, namely: crystalline complex, Permian, and Cretaceous and Tertiary - the last two as one.

Soper, 1914.-A geologic map of Sergipe was published by R. H. Soper in his "Geologia e supprimento d'agua subterranea em Sergipe," etcetera, publication number 34 of the Inspectoria de Obras Contra as Seccas, Rio de Janeiro, July, 1914. It is on a scale of 1 to 1,000,000 and shows four geologic subdivisions, namely: pre-Cambrian, Paleozoic, Permian (?), Cretaceous and Tertiary-the last two as one.

\section{Bibliography of the Geology of Sergipe}

J. C. BranNer: Cretaceous and Tertiary geology of the Sergipe-Alagoas Basin of Brazil. Transactions of the American Philosophical Society, 1889, volume XVI, pages 369-434. Philadelphia, 1889.

J. C. Branner: A geologia cretacea e terciaria da bacia do Brazil Sergipe-Alagoas. Trad. de Garcia Muniz. Publicação dirigida por Laudelino Freire. 12mo. 170 paginas. Aracaju, 1890. (Contains a bibliography.) 
E. D. Cope: A contribution to the vertebrate paleontology of Brazil. Proceedings of the American Philosophical Society, volume XXIII, pages 1-21. Philadelphia, 1886.

Felisbello Firmo de Oliveira Freire: Historia de Sergipe, 1575-1855. Rio de Janeiro, 1891. Caput IV, paginas lii-lxvi, on the geology, is a résumé from Liais and Hartt.

Ch. Fred. HartT : Geology and physical geography of Brazil. Maps and Illustrations, xxiii +620 pages. Boston, 1870. Sergipe, at pages 378-426.

Alpheus HyatT: Report on the Cretaceous fossils from Maroim, Province of Sergipe, Brazil. Hartt's geology and physical geography of Brazil, pages 385-393. Boston, 1870.

Alpheus Hyatr: Pseudoceratites of the Cretaceous. Monograph XLIV, U. S. Geological Survey, Washington, 1913. Vascoceras Harttii from Sergipe, page 108 , plate XIV.

R. H. Sopen: Geologia e supprimento d'agua subterranea em Sergipe e no nordeste da Bahia. Publicação no. 34 da Inspectoria de Obras contra as Seccas. Rio de Janeiro, 1914. 100 paginas e carta geologica.

Chartes A. White: Contribuições a Paleontologia do Brazil (com o original em inglez), Archivos do Museu Nacional. Volume VII, $4^{\circ}$, paginas 1-273, and 28 plates. Rio de Janeiro, 1887. 350 copies of this report were issued as a special edition, dated Washington, January 21,1888 , under the title : "Contributions to the paleontology of Brazil ; comprising descriptions of Cretaceous invertebrate fossils mainly from the provinces of Sergipe, Pernambuco, Para, and Bahia. By Charles A. White."

\section{OdtLines of the Economic Geodocy}

\section{GENERAL OBSERVATIONS}

It is not my purpose to go into details in regard to the economic geology of Brazil. For the use of those who may be interested in this particular branch of the subject, a list of the principal mineral resources of Brazil is given below. It should be clearly understood, however, that this list of minerals of economic importance does not pretend to be complete. For example, the statement that the principal known iron deposits are those of Minas, Matto Grosso, and São Paulo is not meant to imply that iron does not occur in the other states. It must be constantly kept in mind that the geology of Brazil is incompletely known, and much remains to be done in order to disclose all of the mineral resources of the country. New mineral resources are being discovered from time to time, and it is reasonable to believe that Brazil will in time greatly increass the number of her mineral products.

The list of minerals mentioned below must therefore be regarded as only tentative and subject to change in accordance with any facts that may come to light and to developments that may be made. On the other hand, it is one's duty to distinguish between the simple occurrence of a 
mineral and its availability for commercial and industrial purposes. In regions of highly metamorphosed rocks like those of Minas Geraes, Goyaz, parts of Bahia, etcetera, it is to be expected that a long list of minerals should be found, though many of them do not occur in sufficient abundance to give them economic importance, in so far as we now know.

There are no comprehensive works on the general economic geology of Brazil ; but a somewhat remarkable work and one well worth knowing, if used with discrimination, is the "Diccionario Geographico das Minas do Brazil, por Francisco Ignacio Ferreira," published at Rio de Janeiro in 1885. It is mostly a compilation of all the available information regarding the mineral resources, whether real or imaginary, published or unpublished, of each of the Brazilian states, and alphabetically arranged. It contains many notes of value and excerpts from the leading authorities, but it also and necessarily contains much that is worthless or misleading. For example, every state and almost every municipality is said to contain coal, even in the most impossible locations. Of course, the author of the work is not responsible for such claims.

A book of 161 pages, by Dr. Antonio Olyntho dos Santos Pires, entitled "Riquezas Mineraes," published at Bello Horizonte in 1903, gives a good, though brief, historical résumé of the mining industry.

Since the above was written a valuable work has been published, "The Mineral Deposits of South America," by Benjamin L. Miller and Joseph T. Singewald, Jr., New York, 1919. Chapter V, pages 148 to 232, of this book, is upon the economic geology of Brazil, and is accompanied by a brief bibliography.

\section{METALLIO MINERALS *}

Iron.-Extensive iron deposits of excellent quality-mostly hematite, but including magnetite, ochres, and other forms of iron ore-are known in Minas Geraes, São Paulo; Matto Grosso, Goyaz, and Bahia. An important résumé of the manufacture of iron in Brazil is given in the paper on the subject by Dr. Gonzaga de Campos, director of the Geological Service of Brazil. So far as we now know, the high grade ores are confined to the early Paleozoic, but there are large areas of lower grade ores in the Tertiary and Quaternary. The history of the attempts at ironmaking at Ipanema, São Paulo, is given by L. Dupré. The most comprehensive papers on the subject of iron in Brazil are those of-

- In order to use the papers cited by authors under the heads of the various minerals, the reader should find the full titles under the authon's name as given in the bibliographic references of each state. For example, Lisboa (Matto Grosso) means that under Matto Grosso the full title of Dr. Lisboa's paper will be found. 
Bèllo (Minas)

Bovet (Minas)

Calogeras (São Paulo)

Campos

Derby (Minas)

Dupré (São Paulo)

Ferrand (Minas)

Gorceix (Minas)

Graça (São Paulo)

Harder and Chamberlin (Minas)

Kidder (Travels)
Leith and Harder (Minas)

Lisboa (Matto Grosso)

Porto Seguro (Minas)

Richards (Minas)

Schïch (Minas)

Scott (Minas, etcetera)

Sena (Minas)

Silva (São Paulo)

Thirê (Minas)

Wetter (São Paulo)

Gold.-Gold has been mined in almost every state in Brazil, but the principal producing states are Minas Geraes, Matto Grosso, Goyaz, and Bahia. Though Brazil was at one time the greatest gold-producing country in the world, there are now but few rock mines in that country, and those are all in the State of Minas Geraes. A great deal that has been written on the subject has but little or no scientific value. The most important papers are by the following writers:

\author{
Berg (Minas) \\ Böhner (Minas) \\ Bovet (Minas) \\ Brazilian Review (Minas) \\ Costa (Bahia) \\ Cumenge, E. (Minas) \\ Eschwege (Minas) \\ Ferrand (Minas) \\ Gorcelx (Minas, Rio Grande do \\ Sul) \\ Groddeck (Rio Grande do Sul) \\ Hussak (Minas, Goyaz)
}

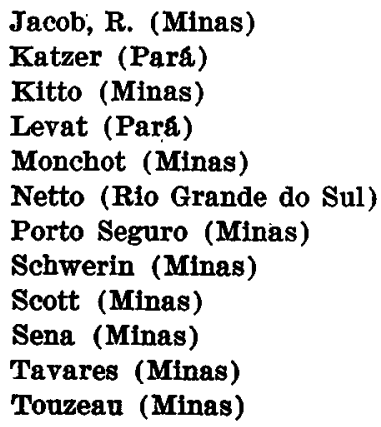

Silver.-Silver is occasionally reported, but in all cases of which $I$ have any knowledge it occurs with lead in the form of argentiferous galena. (See José P. X. da Veiga, Revista do Archivo Publico Mineiro, volume II, pages 757-765. Ouro Preto, 1897.)

Copper.-Copper is known in Bahia, Ceará, Rio Grande do Sul near Lavras, and in Matto Grosso, and it has been. found in small quantities in Minas Geraes near Ouro Preto and Sete Lagoas and in Santa Catharina. The copper ores are mostly in rocks of the Brazilian complex.

The principal papers on copper in Brazil are those of Branner on Bahia, Gorceix, Groddeck, Netto, Scott and Walther on Rio Grande do Sul, Hussak on São Paulo, Small on Ceará, and Vandelli.

Zinc.-Zinc has been found in Minas, but, so far as I have learned, never in commercial quantities (Sena). A little is also found in the 
gold mines of Rio Grande do Sul (Scott). It occurs in rocks of Archean age.

Lead.-Lead is found at Abaeté, in the western part of the State of Minas Geraes, where attempts were made to mine it in 1800 , in 1812 , in 1825, and again in 1880, but thus far without success. It has also been found in a few other places in Minas and in São Paulo, Maranhão, Santa Catharina, and Rio Grande do Sul, but it has never been successfully' worked.

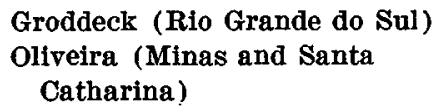

Tin.-Tin has been found in the northern part of Minas, but only as mineral specimens. It is also said to occur in São Paulo near Batea and Antonio Ficou.*

Manganese.-Although Brazil only began the exportation of manganese in 1894, since the year 1896 she has been one of the three greatest producers of manganese ore in the world. The deposits thus far worked are in Minas Geraes and Bahia. Newly discovered deposits have been opened lately on the lands of the Saint John del Rey Mining Company near Morro Velho in Minas, and in the Jacobina mountains near Bomfim in Bahia. Lisboa reports important deposits in Matto Grosso. All of the valuable deposits are in either early Paleozoic or Archean rocks.

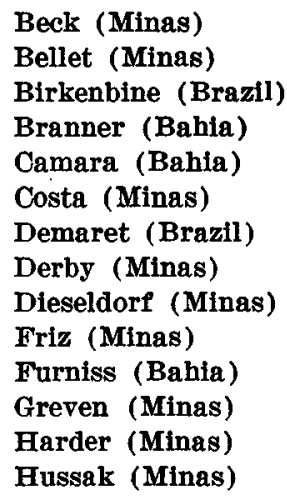

\footnotetext{
* J. C. da. Costa Sena: The occurrence of tin In Minas Geraes. Brazilian Mining Review, vol. 1, pp. 92-93, Rlo de Janetro, Jufy, 1903, and Annaes da Escola de Minas number 6, pp. 5-11. Ouro Preto, 1903.

João Pedro Cardoso: Relatorio da Commissão Geographica e Geologica de Săo Paulo para o anno de 1906, p. 25. Săo Paulo, 1907.
} 
Nickel:-Nickel in the form of garnierite, the hydrous silicate of magnesium and nickel, is known near Livramento, in southern Minas Geraes, in rocks of either Paleozoic or Archean age.*

Chromium.-Chromium is not worked at present in Brazil, but it is probable that it occurs in considerable quantities in connection with the serpentines of Bahia, Minas, etcetera. Williams reports it from Livramento, Minas.

Platinum.-Platinum has long been known from Minas Geraes, but, so far as I have been able to learn, no effort has been made to work it. It appears as sands in connection with the diamond-bearing alluvial deposits, and in the auriferous iron sands of Gongo Soco and of Itabira do Matto Dentro and on Rio Abaeté, in the State of Minas Geraes. Claussen says it is found also at Itambé (Notes géologiques, page 9) and elsewhere in the terrain "traumeteux." The best paper is that of Hussak, an abstract of which is given in the American Journal of Science, fourth series, volume XIX, pages 397-399, 1905.

$\begin{array}{ll}\text { Boussingault (Minas) } & \text { Lampadius } \\ \text { Gehlen } & \text { Svanberg (Analyses) } \\ \text { Humboldt } & \text { Wollaston } \\ \text { Hussak (Minas) } & \end{array}$

Palladium.-Palladium from Brazil is treated of by Lassaigne, Seamon (Minas), Wollaston, and Hussak (Minas). The most comprehensive paper is that of Hussak in the Sitzungsberichte of the Vienna Academy, Abtheilung $I$.

Aluminum.-See Bauxite under non-metallic minerals.

Tungsten.-Tungsten is reported from Espirito Santo and Minas Geraes by Fr. Freise, Zeitschrift der Praktische Geologie, volume XVIII, pages 143-146, Berlin, 1910. The tungsten minerals stolzite and raspite also occur in Minas, but so far as now known only as.mineral curiosities. Tungsten is likely to be found anywhere within the area of the granites and gneisses.

Mercury.-Cinnabar is said to have been found in Minas near Ouro Preto and at Tripuhi and Tres Cruzes. (See Hussak, Machado, and Oliveira.)

Molybdenum.-Franciseo de Paula Oliveira reports molybdenum from Rio de Janeiro on the road from Rio to Petropolis, in Paraná, on Rio Capivary 30 kilometers from Curytiba, and at Bahú, 42 kilometers from Itajahy in Santa Catharina, and associated with copper at Palmas, Rio

\footnotetext{
* H. E. Williams : Nota sobre a occurrencia de um mineral de nickel perto da Villa de Livramento . . Minas Geraes. Boletin do Ministerio da Agricultura, vol. v, no. 1, pp. 21-28. Rio de Janelro, 1916.
} 
Grande do Sul. Its association with granitic rocks leads to the inference that it is to be looked for throughout the Archean area of Brazil. (Francisco de Paula Oliveira: A Molybdenita. Curytiba, 1906.)

\section{NON-METALLIO MINERALS}

Coal, lignite, and peat.-The known coal deposits of Brazil are confined to the States of Paraná, Santa Catharina, and Rio Grande do Sul, where it occurs in beds of lower Permian age. The mines have long been worked in Santa Catharina and Rio Grande do Sul. In Minas lignites are fourd in the Tertiary lake deposits. Lignite occurs over a wide area in the Tertiary beds of the western part of Amazonas. See under "Amazonas." Peat is known near Campos, in the State of Rio de Janeiro. Brazilian coal is high in sulphur, but recent experiments show that it can be successfully used on locomotives in pulverized form.*

A full list of references to coal in Brazil is given at pages 287-300 of I. C. White's Report on the Coal Measures and associated rocks of south Brazil, published in English and Portuguese, xxviii +617 pages, $4^{\circ}$, illustrated, Rio de Janeiro, 1908.

$\begin{array}{lll}\text { Campos, Gonzaga de } & \text { Jordão } & \text { Oliveira, P. J. (Bahia) } \\ \text { Dahne } & \text { Katzer } & \text { Peckenham } \\ \text { Ginty } & \text { Koeller } & \text { Parigot } \\ \text { Gorcelx (Minas) } & \text { Machado (Minas) } & \text { Pederneiras } \\ \text { Grateau } & \text { Macedo } & \text { Plant } \\ \text { Graç } & \text { Meers } & \text { Rechsteinn } \\ \text { Guignet } & \text { Murray } & \text { Santos } \\ \text { Holmes, J. A. } & \text { Oliveira, E. } & \text { Souza } \\ \text { Hull. } & \text { Oliveira, F. de P. } & \text { Thornton } \\ & & \text { White, I. O. }\end{array}$

Petroleum and oil shales.- Up to the present time petroleum has not been found in paying quantities in Brazil. Petroliferous shales, however, have been reported from Alagoas, Bahia, Ceará, Goyaz, Maranhão, Minas Geraes, Paraná, Santa Catharina, São Paulo, Rio de Janeiro, and Rio Grande do Sul. They are found from the Permian to the Pliocene. The most important papers thereon are those of-

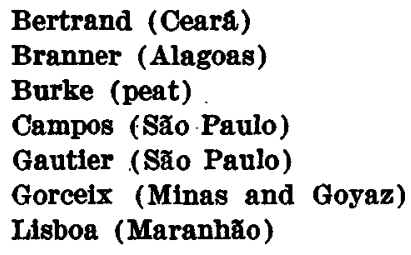

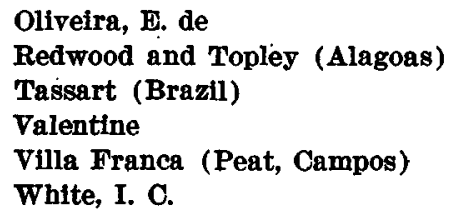

- Arrojado Lisboa: O problema do combustivel nacional. Rio, 1916. p. 1773.

A. V. Adamson: Bul. 144, American Institute of Mining Engineers, December, 1918. 
Asphalt.-Asphalt has been found in the Permian in Paraná, but it has not been worked. It is also said to exist in the Serra do Bufete in São Paulo, where it impregnates sandstone (Euzebio Paulo de Oliveira and I. C: White).

Building stones.-The building stones most extensively used in Brazil are the granites, which occur over large areas, wherever the Brazilian complex forms the surface rocks. The quarries of Rio de Janeiro are famous for their beautiful granites and gneisses.

Marble.-Marble occurs in great abundance in Bahia, Ceará, Espirito Santo, Matto Grosso, Minas Geraes, Parahyba, Pernambuco, Rio de Janeiro, Rio Grande do Norte, Rio Grande do Sul, São Paulo, and Santa Catharina. Stratigraphically, marbles extend from the Archean to the Cretaceous.

Limestone.--Limestones other than marbles are abundant in Para, Ceará, Rio Grande do Norte, Parahyba, Pernambuco, Sergipe, Bahia, Minas Geraes, São Paulo, Paraná, Goyaz, and Matto Grosso. Stratigraphically, they extend from the Archean to the Tertiary. At many places they might readily be used for the manufacture of Portland cement.

Gypsum.-Wells reports a cliff of satin-spar 60 feet high on Rio Grajahú, State of Maranhão, a few kilometers down stream from the port of Chapada. ${ }^{82}$

Anhydrite.-Anhydrite is reported in Minas Geraes near Sabará (Liais, Géologie, 139).

Magnesite.-Magnesite is reported from Archean areas at Rio Pardo and Rio Capivary, in Rio Grande do Sul, but it may be expected in Bahia and Minas and in connection with the serpentines and dolomites, wherever they occur in Brazil-usually in the Brazilian complex. Information available about the magnesite of Rio Grande do Sul is very meager.

Kaolin, clay, fullers earth.-Kaolin is found at many places where the feldspathic rocks of the Brazilian complex are deeply decomposed : Minas, Espirito Santo, Rio de Janeiro, etcetera. There is an important ceramic factory at Caethe, in Minas, where the local clays are used. ${ }^{83}$

Glass sands.-Glass sands are abundant here and there along the coast of Brazil from Espirito Santo northward to the mouth of the Amazon. There are some noteworthy deposits near the mouth of Rio Formoso, State of Pernambuco. These sands are usually Quaternary or Recent.

82 J. W. Wells: Three thousand mlles through Brazll, vol. 11, p. 268.

8 Cypriano J. Carvalho: Ceramica Nacional fundada em Caethe, Estado de Minas. pelo Dr. Joăo Pinheiro. Revista Industrial de Minas, vol. iil, pp. 213-218, 15 de Agosto e 15 de Setembro de 1896 . 
Asbestos.-Asbestos has been found in Bahia, where it is associated with serpentines, and from Santa Luzia, State of Minas. There is said to be a deposit at Taquaral near Ouro Preto and one near Caethe, at a place called Retiro. (Francisco de Paula Oliveira: Revista Industrial de Minas Geraes, volume I, page 15, October, 1893.)

Talc.-Talc occurs in large quantities in the old metamorphic rocks of the Brazilian complex in Bahia and Minas Geraes, and probably in many other states, in association with the crystalline rocks. It has long been used locally for making certain cooking utensils, but otherwise it is not used at present.

Mica.-Mica is known to occur in São Paulo at Juquiá, Goyaz, Espirito Santo, Minas Geraes (at Bicas, and near Manhuassu, near Santa Luzia de Carangola, and at Fonseca), Rio de Janeiro near São Fidelis, Sergipe and in Bahia east of the Serra de Jacobina, and near the falls of Paulo Affonso. It is to be expected in pegmatite dikes in all states within the area of the crystalline rocks.*

Salt.-Salt is common in the dry or semi-arid limestone regions of the interior. Before the days of railways, large quantities of salt were manufactured in the interior, but its manufacture is now almost abandoned, on account of the facilities for obtaining it elsewhere and the better quality to be had from the seacoast. The salt made in the interior is produced by leaching the efflorescence and earth from dry lake beds and then evaporating the water thus obtained. Places noted for the former manufacture of such salt are the Salitre Valley, in Bahia; Rio Mosquito; in Minas near Grão Mogol, and elsewhere in the limestone areas of the Rio São Francisco and Goyaz. So far as I have been able to learn, no beds of rock-salt in place are known in Brazil. In the valley of the São Francisco the salt seems to have some definite relation to the Permian limestones, but as yet it is not clear what that relation is.

Niter.-Niter deposits are often mentioned as Quaternary and Recent cave deposits. They are found in the caves of all parts of Brazil, notably in the States of Ceará, Pernambuco, Bahia, Espirito Santo, Minas Geraes, and Matto Grosso.

The industry is an uncertain one, and under ordinary circumstances the output is used only for the local manufacture of gunpowder. It is capable of considerable development.

\footnotetext{
* João Pedro Cardoso : Relatorio da Commissão Geographica e Geologica de São Paulo, anno de 1907.

H. K. Scott: On the occurrence of mica in Brazll. Transactions of the Institute of Mining and Metallurgy, vol. xil, pp. 351-364. London, 1902-3.
} 
Couto (Minas)

Miranda (Minas)
Prates (Minas)

Silveira (Minas)

Some of the leucite-bearing rocks of Brazil may yet become available for the manufacture of potash. Foyite containing 8.78 per cent of potash $\left(\mathrm{K}_{2} \mathrm{O}\right)$, and leucite-tinguaite containing 8.86 per cent of potash, are found in the Serra do Tinguá in the State of Rio de Janeiro; leucitophyre, with 8.12 per cent, is found at Poço de Caldas, and leucite granite porphyry, with 8.80 per cent of potash $\left(\mathrm{K}_{2} \mathrm{O}\right)$, is found on Rio Pardo in the Serra de Caldas. The last two places are in southwestern Minas Geraes.

Graphite.-Graphite is found in Archean rocks in Minas near São Miguel $^{84}$ and about Minas Novas, but it is not known to have been mined. It is reported near Abrantes, northeast of Bahia. Freise reports it from Espirito Santo and Wells reports it from east of Chapada, in the State of Maranhão. ${ }^{85}$ It seems to be confined to the areas of the Brazilian complex.

Bauxite.-Bauxite has been found in southwestern Minas, in the vicinity of Poço de Caldas, where it is derived by decomposition from alkaline igneous rocks. Doctor Lisboa reports it in the State of Maranhão. It occurs in the form of sedimentary deposits along some of the tributaries of the lower Amazon River, in the State of Pará. It has not yet been worked anywhere in Brazil.

Later discoveries made in Minas lead to the reasonable expectation that extensive beds may yet be found in Brazil. See under Minas Geraes.

Monazite.-The monazite deposits of Brazil have been .known and worked only since 1888 . They occur as beach sands that have been washed directly from Tertiary sediments : that were derived originally from the underlying crystalline rocks of the Brazilian complex where it is a wide-spread rock constituent. 'The deposits that are worked are along the beach in the vicinity of Prado, State of Bahia, and on the coast of Espirito Santo north of Victoria. In the first volume of his "Minas do Brasil e sua legislação, Dr. João P. Calogeras gives a good résumé of the subject at pages $447-477$ and adds a brief bibliography.

$\begin{array}{lll}\text { Bohm } & \text { Bulhões } & \text { Derby } \\ \text { Britto } & \text { Calogeras } & \text { Furniss } \\ \text { Gorceix } & \text { Medrado } & \text { Richardson } \\ \text { Hussak and } & \text { Murtinho } & \text { Uhlig } \\ \quad \text { Reitinger } & \text { Praguer } & \\ \text { Lisboa } & & \end{array}$

84 J. C. da Costa Sena : Annaes da Escola de Minas, vol. il, 1883, pp. 125, 129.

$8 \mathrm{~J}$. W. Wells: Three thousand miles, etc., vol. 11, p. 260. 
Zirconia.-The oxide of zirconia, which has been exported from Brazil in considerable quantities within a few years past, is derived by decomposition from nepheline syenites and other kindred rocks. The material was first found as water-worn pebbles in stream beds and as angular fragments scattered over the ground in the vicinity of the nepheline rocks from which they were derived. These rocks are found in the vicinity of Caldas, in the State of Minas Geraes, and near Franca and Jacupiranga, in the State of São Paulo. It is probable that this mineral may occur in other places in Brazil where there are nepheline syenites. They are known at present at Cabo Frio, Campo Grande, Itatiaia, and the peak of Tingua, State of Rio de Janeiro, and they probably occur at many other places in Brazil. (See Derby on the nepheline rocks of Brazil, and E. Hussak and J. Reitinger on zirconia, Groth's Zeitschrift fiir Krystallographie, 1903, volume 37, pages 550-579.)

Phosphates.-The island of Fernando de Noronha, off the northeast coast of Brazil; is the only place that is known to produce phosphate rock. It is found there as a Recent or Quaternary deposit, on the small island known as Tha Rapta. A few cargoes are said to have been shipped, but the lack of landing facilities is said to have prevented the establishment of an export business.

Papers have been published on the subject by Bovet, Derby, Lasne, Sena, and Sobragy.

Diamonds.-Diamonds have been mined in Minas Geraes, Matto Grosso, Bahia, and Paraná. The diamond-mining industry of Brazil declined greatly after the discovery of diamonds in South Africa, but it is still conducted on a small scale. Most of the diamonds lound in Brazil have been taken from existing stream channels, or from old stream deposits where they have been concentrated by natural processes from the rocks of the surrounding region. Specimens have occasionally been found imbedded in the hard rocks, usually in gravels cemented by iron and evidently not in place, but they have also been found in Paleozoic quartzites. Much has been written upon the origin of the Brazilian diamonds, but, whatever their remote origin may have been, they have thus far been found in paying quantities in Brazil only in stream channels or other deposits formed by concentration. In Paraná they appear to be derived from a Devonian basal conglomerate. In Bahia they come from pink quartzites tentatively referred to the Carboniferous. At Grão Mogol, in northern Minas, they also occur in quartzites. The minerals associated with diamonds in Brazil suggest that their genetic relations are with deep-seated granites, metamorphics, and pegmatites rather than with eruptives. In the State of Bahia, at least, no eruptive rocks 
are known in the neighborhood of the diamonds, except at a single place where a small diabase dike breaks through the diamond-bearing quartzites without affecting perceptibly the surrounding rocks. In spite of their great economic importance, there has never been any systematic work done on the geology of the diamonds of Brazil, and, as Calogeras well remarks, "presque tous les gisements diamantiferes du Brésil ont eté découverts par hazard." 88

From private sources I have lately heard reports of the discovery of diamonds at several places in the State of Minas Geraes in peridotite pipes similar to those in which diamonds occur in South Africa. These reports require confirmation.

$\begin{array}{ll}\text { Bovet } & \text { Galvão } \\ \text { Boutain } & \text { Gorceix } \\ \text { Boué } & \text { Glocker } \\ \text { Bensaude } & \text { Haidinger } \\ \text { Branner } & \text { Helmreichen } \\ \text { Campos } & \text { Heusser v. Claraz } \\ \text { Castelnau } & \text { Hocheder } \\ \text { Claussen } & \text { Heuland } \\ \text { Cugnier } & \text { Hussak } \\ \text { Damour } & \text { Jacob and Chartrain } \\ \text { Dawson, T. } & \text { Jannetaz } \\ \text { Dié } & \text { Jardim } \\ \text { Dennis 2 } & \text { Jeremejew } \\ \text { Derby (Paraná) } & \text { Kunz } \\ \text { Dieulafait } & \text { Lawrence } \\ \text { Dufresnoy } & \text { Lindsay } \\ \text { Engelhardt } & \end{array}$

\author{
Limonosoff \\ Martius \\ Mawe \\ Moissan \\ Nusser-Asport \\ Oliveira, F. de P. \\ Oliveira (Salobro) \\ Pereira \\ Pires (Ant. O) \\ Porcheron \\ Praguer \\ Rezende \\ Rivot \\ Schwartz (Bahia) \\ Silva (Bahia) \\ Vandelli
}

Carbonados, or black diamonds.-Carbonados are only found in considerable numbers in the State of Bahia, where they are associated with ordinary diamonds. ${ }^{87}$ Like diamonds, they are found in stream beds and in old stream deposits, but they have been derived directly from quartzites. The rocks of the surrounding region from which the carbonados have come are all gently folded, false-bedded, pinkish quartzites, and wherever these quartzites have softened by weathering, the miners have broken them up and washed them for the carbonados thus set free. These carbonado-bearing rocks are possibly of Carboniferous age, but no fossils have yet been found in them and their age is therefore in doubt. The region of the black diamond is hilly and for the mest part forestcovered. It is supposed that the carbonados have originated in the same

\footnotetext{
${ }^{86}$ Revista Industrial de Minas Geraes II, 5, 15 de Junho de 1895.

${ }^{81}$ Dr. Antonio Olyntho reports carbonados from Rio Abaete in the State of Minas Geraes. Annaes da Escola de Minas, number 4, page 115. Rio de Janeiro, 1885.
} 
way as the diamonds, but their origin is not altogether clear. It seems quite evident; however; that they are not genetically or directly related to volcanic rocks.

The geology of the black diamond region of Bahia is described by Branner, Crandall, and Derby. Other writers on carbonados are Baszanger, Damon, Descloiseux, Furniss, Gama, Gullana, Lawrence, Moissan, Rowe, and Stehr.

Other precious stones.-Brazil has produced many precious stones besides diamonds, notably rubies, garnets (Oliveira), emeralds, agates, topazes (Gorceix), phenacites (see Goldschmidt, Slavek, Smith). The phenacites are from Piracicaba, State of Minas. (See also Hussak and Fernandes.) These stones usually come from the regions of the Brazilian complex; the agates come chiefly from Rio Grande do Sul, where they have weathered from the "trapp". beds.

\section{The Mining Laws of Brazil}

\section{GENERAL OBEERVATIONS}

In Boubée's "Geologia Elementar," published in Rio de Janeiro in 1846, there is an appendix, without the name of the author, entitled "Indice da legislação Portuguese sobre as minas do Brasil," which brings the subject down ot the year 1816 .

A chronologic list of the old mining laws of Brazil is given in "Tivro das terras, ou colleção de leis, regulamentos e ordens," etcetera, etcetera, por I. M. P. de Vasconcellos, 4ª edição, Rio de Janeiro, 1885, pages 251266, under the title "Legislação a respeito das minas. Indice chronologico das leis sobre minas do Brazil desde o seu descobrimento até 181\%." (Extrahido do archivo da Torre do Tombo de Lisboa.)

When the Republic of Brazil was established the new constitution made the following provisions in regard to public lands:

Article 64: "The mines and lapsed lands in their respective territories belong to the States, the Union being entitled only to the amount of territory that may be indispensable for the defense of the frontiers, fortifications, military constructions, and federal railways."

Artlcle 72, section 17: "The right of ownership is maintained in all its fullness, excepting disappropriation for public necessity or utility and after previous indemnity.

"The mines belong to the owners of the soll, excepting the limitations that may be established by law for aiding the exploration of this branch of industry."

These provisions lead one to infer that legislation in regard to mining lands lies. with the individual states. However, the National Congress 
of Brazil passed a general mining law, and it was approved and put in force by the President January 6, 1915. It is decree number 2933. This law, translated into English, may be seen with the Bureau of Mines at Washington.

So far as I know, Bahia is the only state that has a code of mining laws. In other states legislation in regard to mineral lands is more or less indirect, obscure, and unsatisfactory.

The early history of mining in the State of Minas Geraes is given in Dr. Felicio dos Santos' Memorias do Districto Diamantino, chapter 28, pages 295-307, Rio de Janeiro, 1868. The mining laws of the State of Minas Geraes are listed in the Annaes da Escola de Minas, number 3, pages 239-250, Rio de Janeiro, 1884.

A brief history of mining in Brazil is given by Dr. Antonio Olyntho dos Santos Pires in his paper, "A Mineração; Riquezas Mineraes," published at Bello Horizonte in 1903, and in the "Livro do Centenario;" volume III. It was also published in English in the "Brazilian Mining Review," at Rio de Janeiro, volumes II and III.

In his third volume, beginning at page 243 , Dr. Calogeras gives a résumé of the legislation of the various states existing at the time his book on "As minas do Brasil e sua legislação" was published, in 1905. (See third title below.)

\section{BIBLIOGRAPHIO REFERENOES TO MINING LAW}

Francisco Ianacio Ferretra: Repertorio Juridico do Mineiro. Consolidação alphabetico e chronologica de todas as disposições sobre minas. 356 paginas. Rio de Janeiro, 1884.

A. H. DE Souza Bandeina : A propriedade das minas. Estudo de direito administrativo. $8^{\circ}, 75$ paginas. Rio de Janeiro, 1885.

João Pandí Catoghras: As minas do Brasil e sua legislação. $8^{\circ}$, volume $I$, 479 paginas. Rio de Janeiro, 1904 . Volume II, 627 paginas, 1905; volume III, 243 paginas. Rio de Janeiro, 1905.

João Pandia Calogeras: A lei de minas. (Parecer da Commissão Especial [da Camara dos Deputados].) 8, 110 paginas. Rio de Janeiro, 1914.

State of Bahia: Regulamento geral de minas, para execução da lei no. 624 de 9 de Setembro de 1905. Bahia, 1907.

(The Federal minivg laws of Bratil:) Decreto Legislativo no. 2933, de 6 de Janeiro de 1915. Regula a propriedade das minas. Ministerio da Agricultura, Industria e Commercio. $8^{\circ}, 15$ paginas. Rio de Janeiro, 1915.

\section{Works of Travel in Brazil}

Those who work or travel in Brazil and those who wish to inform themselves about that country will naturally want to read books of travel thereon. The following are mostly old books, but they are among the 
best. In reading them one must keep in mind that modern improvements have worked great changes in Brazil, just as they have in other countries. A valuable late work is "Brazil today and tomorrow," by L. E. Elliott, $x i+338$ pages, New York, 191\%. It is not a work of travel, but it gives much useful and trustworthy information about the country at the present time.

Professor and Mrs. Lours Agassiz: A journey in Brazil. xix +450 pages, illústrated. Boston, 1868. This work was published in French at Paris, 1869.

HENBY WaLTER Bates: The naturalist on the River Amazon. Several editions, illustrated. London, 1863 to 1892 . A delightful book describing the anthor's life in the upper Amazon Valley.

Thomas P. Biga-Withrer: Pioneering in south Brazil. Two volumes, illustrated. London, 1878. The author was a civil engineer; his book tells of his life in the interior of Parana.

RioHard F. Burton: Explorations of the highlands of Brazil. Two volumes, illustrated. London, 1869. The book describes a trip through Minas Geraes and down Rio São Francisco to the ocean.

Grorge Gardner: Travels in the interior of Brazil . . . during the years 1836-1841. $8^{\circ}$, xvi +562 pages. London, 1846 and 1849 . The author was an English botanist; most of his travels were in Ceara, Piauhy, Bahia, and Minas Geraes.

DANIRI: KTDDER: Sketches of residence and travel in Brazil. Two volumes, illustrated. Philadelphia, 1845. Dr. Kidder was a Protestant missionary. He traveled over nearly all of Brazil and wrote simply and clearly.

Henty Koster: Travels in Brazil. Second edition, two volumes. London, 1817. It has been published also in French and German. The author traveled in Pernambuco, Parahyba, Rio Grande do Norte, and Ceará.

AIGOT LANGE: The lower Amazon. $8^{\circ}$, illustrated, 460 pages. New York, 1914. Observations in regard to the conditions of life in the region about Para.

JoH N MAWE: Travels in the interior of Brazil, particularly in the gold and diamond districts of that country. $8^{\circ}$, illustrated. Philadelphia, 1816. There are other editions besides those in French, Italian, Dutch, and German. This is the first authentic account of the mining regions of Brazil.

Auguste DE SatrT-HiraIRE: This author was a distinguished French botanist who wrote a series of volumes giving detalled accounts of his travels in different parts of Brazil. He was a keen observer and a faithful, trustworthy writer. His travels are given here in the order of their publication:

1. Voyage dans les provinces de Rio de Janeiro et de Minas Geraes. Two volumes. Paris, 1830.

2. Voyage dans le district des dlamans et sur le littoral du Brésil. Two volumes. Paris, 1833.

3. Voyage aux sources du Rio de São Francisco et dans le province de Goyaz. Two volumes. Paris, 1848.

4. Voyage dans l'interieur du Brésil. Two volumes. Paris, 1850.

5. Voyage dans les provinces de Saint Paul e de Sainte Cathérine. Two volumes. Paris, 1851. 
HerBert H. Smith : Brazil, the Amazons and the coast. $8^{\circ}$, illustrated, 644 pages. New York, 1879.

RICHARD SPRUCE: Notes of a botanist on the Amazon and Andes, edited by A. R. Wallace. Two volumes, illustrated. London, 1908.

JAMES W. WELLS: Exploring and traveling three thousand miles through Brazil from Rio de Janeiro to Maranhão: Two volumes, $8^{\circ}$, illustrated. London, 1886. The author was a civil engineer; the book is interesting and trustworthy, but it contains a great many absurd errors in Portuguese.

\section{Cimmatic Conditions}

Inasmuch as Brazil lies mostly within the tropics, it is important that the climatic conditions be kept in mind, both in connection with fieldwork in geology and with the carrying on of mining and other operations directly related to geology.

Some parts of Brazil have as fine climate as can be found anywhere in the world; such are the highlands of Minas Geraes and Goyaz and the southern states-São Paulo, Paraná, Santa Catharina, and Rio Grande do Sul. The high, dry parts of the interior are psually healthful, but the swampy, forest-covered portions of Amazonas, Pará, and Matto Grosso should be avoided unless one is proof against malarial and intestinal diseases.

Of the practical difficulties of dealing with malarial and other tropical diseases in the Amazon forest regions one can get an idea by reading "Recollections of an ill-fated expedition to the headwaters of the Madeira River in Brazil," by Neville B. Craig, Philadelphia, 190\%. No one should delude himself by supposing that the sanitary measures that have been so successfully carried out on the Panama Canal Zone and in the city of Rio de Janeiro are practicable in a region like that of the Amazon Valley.

Good works on the climate of Brazil are:

F. M. Draenert : O clima do Brasil. Rio de Janeiro, 1890.

L. Cruls: Le climat de Rio de Janeiro (also in Portuguese). Rio de Janeiro, 1892.

L. Cruls : Le climat du Brésil, Paris, 1896.

C. M. Delando de Garvalho: Météorologie du Brésil. $8^{\circ}$, illustrated. London, 1917. This last has a bibliography at pages 518-525. 
